\title{
ISSN 2541-8874
}

BCrYhK

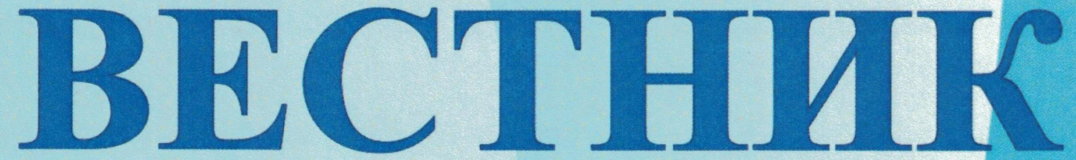

Восточно-Сибирского государственного института культуры 
Министерство культуры Российской Федерации ФГБОУ ВО «Восточно-Сибирский государственный институт культуры»

\section{В Е С Т Н И К \\ Восточно-Сибирского государственного института культуры}

Научный журнал по искусствоведению, культурологии, историческим наукам

\section{№2(10)}

Улан-Удэ

Издательско-полиграфический комплекс ФГБОУ ВО ВСГИК 2019 
Учредитель: ФГБОУ ВО «Восточно-Сибирский государственный институт культуры»

\author{
Свидетельство о регистрации \\ ПИ № ФС 77 - 74824 от 21 января 2019 г. \\ Федеральная служба по надзору в сфере связи, \\ информационных технологий и массовых коммуникаций
}

(Роскомнадзор)

Журнал включен в систему РИНЦ

Редакционная коллегия

Р.И. Пшеничникова, проф., академик МАН ВШ (гл. редактор); Е.Ю. Перова, кан. эконом. наук, доцент (зам. гл. редактора); И.С. Цыремпилова, д-р ист. наук, проф. (зам. гл. редактора); И.Б. Батуева, д-р ист. наук, проф.; Т.Н. Бояк, д-р социол. наук, проф.; Н.Б. Дашиева, д-р ист. наук, проф.; С.А. Езова, канд. пед. наук, проф.; В.Л. Кургузов, д-р культурологии, проф.; 3.А. Серебрякова, д-р филол. наук, доцент; С.Г. Степанова, канд. пед. наук, доцент; С.П. Татарова, д-р социол. наук, проф.; C.А. Харитонова, канд. пед. наук, доцент (отв. секретарь); Э.В. Хилханова, д-р филол. наук, проф.; Д.Л. Хилханов, д-р социол. наук, проф.; Л.М. Хобракова, канд. филол. наук, доцент; Н.Д. Хосомоев, канд. филол. наук, проф.; А.В. Чебунин, д-р филос. наук, доцент.

\title{
В $\mathbf{E}$ С института культуры. - Улан-Удэ, 2019. - №2(10).
}

Адрес издателя, редакции и типографии ФГБОУ ВО «ВосточноСибирский государственный институт культуры» 670031, Республика Бурятия, г. Улан-Удэ, ул. Терешковой, д. 1. Телефон: (3012) 23-29-83; e-mail: vestnikvsgik@mail.ru

Выход в свет 12.07.2019. 70x108 1/16. Усл. печ. л. 15,4. Уч.-изд. л. 10,03. Тираж 500 экз. Заказ № 2361. Цена свободная.

Отпечатано в Издательско-полиграфическом комплексе ФГБОУ ВО ВСГИК 670031, г. Улан-Удэ, ул. Терешковой, 1.

(C) ФГБОУ ВО «Восточно-Сибирский государственный институт культуры»»), 2019. 
Васильева Н.Ю.

ЭЛИТНЫЙ ПОГРЕБАЛЬНЫЙ КОМПЛЕКС АЗИАТСКИХ ГУННОВ «ЦАРАМ» (ПО МАТЕРИАЛАМ АРХЕОЛОГИЧЕСКИХ

ИССЛЕДОВАНИЙ СЕРГЕЯ СТЕПАНОВИЧА МИНЯЕВА) .6

Цыремпилов Д.В.

ФОНД № 159 «ВЕРХНЕУДИНСКИЙ ОКРУЖНОЙ ОСПЕННЫЙ КОМИТЕТ» КАК ИСТОЧНИК ПО ИСТОРИИ ОСПОПРИВИВАНИЯ В ВОСТОЧНОЙ СИБИРИ ХІХ в.

Хамаева Е.Д.

ДЕЯТЕЛЬНОСТЬ ТРОИЦКОСАВСКОЙ ПОЧТОВО-ТЕЛЕГРАФНОЙ КОНТОРЫ В КОНЦЕ ХІХ-ХХ ВВ. В ДОКУМЕНТАХ

ГОСУДАРСТВЕННОГО АРХИВА РЕСПУБЛИКИ БУРЯТИЯ

Матющенко О.И.

МУЗЕЙНЫЕ ПРЕДМЕТЫ СО ВСЕГО СВЕТА: КАК

КОМПЛЕКТОВАЛИСЬ ФОНДЫ МУЗЕЕВ ИМПЕРАТОРСКОГО

ТОМСКОГО УНИВЕРСИТЕТА

Санданов Д.В., Батоцыренов Э.А.

ОСОБЕННОСТИ ВЕСЕННЕГО ЦВЕТЕНИЯ РАСТЕНИЙ БУРЯТИИ:

АНАЛИЗ АРХИВНЫХ ФЕНОЛОГИЧЕСКИХ МАТЕРИАЛОВ

Новолодская М.С.

ИСТОРИЯ ПОВСЕДНЕВНОСТИ: УРОВЕНЬ ДОХОДОВ РАБОЧИХ

ЛЕСНОЙ ПРОМЫШЛЕННОСТИ БУРЯТИИ НАЧ. 1930 - кон. 1950-х гГ. ...47

Кравцова Л.А.

АКТУАЛИЗАЦИЯ ИСТОРИКО-КУЛЬТУРНОГО НАСЛЕДИЯ

УГОЛЬНОЙ ОТРАСЛИ КУЗБАССА КАК ФАКТОР ФОРМИРОВАНИЯ

ШАХТЕРСКОГО ОБРАЗА КЕМЕРОВСКОЙ ОБЛАСТИ

КУЛЬТУРОЛОГИЯ

Долгополова Л.В., Суптелова А.В.

КОМПЛЕКС БОЯРЫ-АБАКАНО-ПЕРЕВОЗ КАК ТУРИСТИЧЕСКИЙ

РЕСУРС РЕСПУБЛИКИ ХАКАСИЯ.

Донгак В.Ч.

ОБЗОР КОЛЛЕКЦИЙ: МЕЛКИЕ МЛЕКОПИТАЮЩИЕ

ТАКСИДЕРМИЧЕСКИХ РАБОТ В ФОНДАХ НАЦИОНАЛЬНОГО

МУЗЕЯ РЕСПУБЛИКИ ТЫВА

Монгуш Ш.Х.

ТУВИНСКИЕ ПОДУШКИ В СОБРАНИИ НАЦИОНАЛЬНОГО МУЗЕЯ

ИМ. АЛДАН-МААДЫР РЕСПУБЛИКИ ТЫВА

Свистов Н.Л.

МУЗЕЙНО-ОБРАЗОВАТЕЛЬНЫЙ КОМПЛЕКС «ПАЛЕОДЕРЕВНЯ»

КАК ПРИМЕР ИНТЕГРАЦИИ В СОЦИОКУЛЬТУРНОЕ

ПРОСТРАНСТВО ЮГА ДАЛЬНЕГО ВОСТОКА 
Румянцева А.С., Епина М.Б., Терскова А.А.

КУЛЬТУРНО-ПРОСВЕТИТЕЛЬСКАЯ, ОБРАЗОВАТЕЛЬНАЯ И

МЕМОРИАЛЬНАЯ ДЕЯТЕЛЬНОСТЬ МУЗЕЯ СИБИРСКОГО

ФЕДЕРАЛЬНОГО УНИВЕРСИТЕТА

Гульбина А.А., Жушиховская И.С.

ИНТЕРАКТИВНЫЙ ПОДХОД К ПОПУЛЯРИЗАЦИИ НАУЧНЫХ

ЗНАНИЙ (ОПЫТ МУЗЕЯ «ПРИРОДА МОРЯ И ЕЕ ОХРАНА») .105

Бальжитова О.М.

МУЗЕЙ В СОЦИАЛЬНО-КУЛЬТУРНОЙ РЕАБИЛИТАЦИИ ЛЮДЕЙ С ОГРАНИЧЕННЫМИ ВОЗМОЖНОСТЯМИ ЗДОРОВЬЯ.

Васильев В.М.

ФОРМИРОВАНИЕ ЭКОЛОГИЧЕСКОЙ КУЛЬТУРЫ МУЗЕЙНЫМИ

ТЕХНОЛОГИЯМИ

ИСКУССТВОВЕДЕНИЕ

Цибудеева Н.Ц.

НАУЧИТЬ ПОНИМАТЬ ПРЕКРАСНОЕ

Цыренжапова Л. М.

МАРКЕТИНГОВАЯ ПОЛИТИКА АРТ-МЕНЕДЖМЕНТА

В АРТ-ИНДУСТРИИ

ОБРАЗОВАНИЕ В СФЕРЕ КУЛЬТУРЫ И ИСКУССТВА

Дандарон М. Б., Замоева Е. К.

РОЛЬ НАУКИ В СОВРЕМЕННОМ ОБРАЗОВАНИИ

Ян Ли

ПРИМЕНЕНИЕ ЛЕКСИЧЕСКОГО ПОДХОДА «ИЕРОГЛИФ КАК

ОСНОВНАЯ ЕДИНИЦА» ПРИ ОБУЧЕНИИ КИТАЙСКОМУ ЯЗЫКУ

КАК ИНОСТРАННОМУ

Николаева Н.В.

О НЕКОТОРЫХ ПРОБЛЕМАХ ОРГАНИЗАЦИИ ПРАКТИКИ В

ПРОЦЕССЕ ОБУЧЕНИЯ СТУДЕНТОВ ПО НАПРАВЛЕНИЮ

ПОДГОТОВКИ «РЕЖИССУРА ТЕАТРАЛИЗОВАННЫХ

ПРЕДСТАВЛЕНИЙ И ПРАЗДНИКОВ»

Покацкая Е. И.

ДИНАМИКА МОТИВАЦИИ СТУДЕНТОВ ТВОРЧЕСКОЙ

СПЕЦИАЛЬНОСТИ В ПРОЦЕССЕ ОБУЧЕНИЯ В ВУЗЕ

РЕЦЕНЗИЯ

Семенов Е.В.

РЕЦЕНЗИЯ НА КНИГУ: NIEBELSKI Е. JÓZEF PILSUDSKI NA SYBERII 1887-1892. - LUBLIN : POLIHYMNIA, 2018. - 319 С. = НЕБЭЛЬСКИЙ Е. ЮЗЕФ ПИЛСУДСКИЙ В СИБИРИ. 1887-1892 ГГ. - ЛЮБЛИН :

POLIHYMNIA, 2018. - 319 C.

СВЕДЕНИЯ ОБ АВТОРАХ 


\section{Уважаемый читатель!}

Настоящий номер научного журнала «Вестник Восточно-Сибирского государственного института культуры» традиционно содержит четыре раздела: «Исторические науки», «Культурология», «Искусствоведение», «Образование в сфере культуры и искусства». Тем не менее, номер необычный, так как в разделах «Исторические науки» и «Культурология» представлены материалы II Всероссийской научной конференции «Интеграция музеев Сибири в социокультурное пространство и мировое музейное сообщество: Наука. Наследие. Общество». Конференция пройдет в рамках юбилейных мероприятий 50-летия Музея Бурятского научного центра СО РАН. Среди авторов - исследователи, преподаватели высших учебных заведений и сотрудники музеев и архивов Сибири и Дальнего Востока: Томск, Кемерово, Кызыл, Красноярск, Улан-Удэ, Кяхта, Владивосток. Причем, статьи выходят за рамки традиционных публикаций, посвященных формированию, изучению и описанию коллекций и фондов. Авторы ставят и решают проблемы взаимодействия науки, музеев и общества в социокультурном аспекте, рассматривают интерактивные методы популяризации наследия, анализируют музейные и архивные коллекции как источник и результат научных изысканий.

В материалах раздела «Искусствоведение» рассмотрены становление и специфика музыкального образования в Бурятии, а также особенности применения маркетинговых инструментов в арт-индустрии.

Раздел «Образование в сфере культуры и искусства» представлен статьями, отражающими широкий спектр вопросов: от роли науки в образовании, методики преподавания китайского языка до исследования мотивации студентов и проведения практик в творческих вузах.

В разделе «Рецензия» автор анализирует монографию польского историка, изданную в Люблине, и впервые знакомит научную общественность России с сибирским периодом жизни Юзефа Пилсудского.

От редколлегии 


\section{ИСТОРИЧЕСКИЕ НАУКИ}

DOI 10.31443/2541-8874-2019-2-10-6-14

УДК 069:908(571.54-21)+902/904

\section{Васильева Н.Ю.}

Vasilyeva N.Yu.

ЭЛИТНЫЙ ПОГРЕБАЛЬНЫЙ КОМПЛЕКС АЗИАТСКИХ ГУННОВ - «ЦАРАМ»

(ПО МАТЕРИАЛАМ АРХЕОЛОГИЧЕСКИХ ИССЛЕДОВАНИЙ СЕРГЕЯ СТЕПАНОВИЧА МИНЯЕВА)

PREMIUM BURIAL COMPLEX OF THE ASIAN HUNS “TSARAM" (ON THE MATERIALS OF SERGEY STEPANOVICH MINYAEV'ARCHAEOLOGICAL RESEARCH)

В статье дан обзор коллекции археологических находок эпохи хунну из фондов Кяхтинского краеведческого музея. Основное внимание уделено находкам, сделанным археологом С.С. Миняевым (Эрмитаж) во время раскопок хуннского кургана в пади Царам. На основе работ С.С. Миняева дано описание конструкции, погребальной камеры, наиболее интересных артефактов, погребальных кукол.

The article reviews the collection of the archeological findings of the Huns age from the funds of Kyakhta local history museum. The special attention is given to the findings made by the archaeologist S.S. Minyaev (the Hermitage) during the excavations of the Huns kurgan in the fold Tsaram. The description of the construction, burial chamber, more interesting artifacts, burial dolls is given on the basis of S.S. Minyaev' works.

Ключевые слова: музей, коллекция, археология, хунну, курган, С.С. Миняев, Кяхта.

Keywords: museum, collection, archaeology, the Huns, kurgan, S.S. Minyaev, Kyakhta.

Археологическая коллекция Кяхтинского краеведческого музея имени академика В.А. Обручева насчитывает более 13000 музейных предметов. Наиболее ценной является коллекция предметов материальной культуры и искусства азиатских гуннов (сюнну, хунну). Она превосходит по своему объему и разнообразию аналогичные коллекции, как в России, так и за рубежом.

Сюнну (хунну, или азиатские гунны) - скотоводческие племена, овладевшие в последние века до нашей эры огромными пространствами Центральной Азии. Объединение племен, сложившееся под властью сюнну, сыграло важнейшую роль в истории степного пояса Евразии. Сюннуские завоевания на рубеже III- II вв. до н.э. положили конец «скифскому» 
периоду в развитии этого региона и ознаменовали наступление эпохи, которая стала связующим звеном между первобытностью и цивилизацией. В рамках племенного союза, влияние которого распространялось от Енисея до Маньчжурии и от плато Ордос до Байкала, за короткое время сложились новые формы материальной культуры и общественных отношений, бытовавших затем на протяжении длительного периода.

Исследования археологических памятников азиатских гуннов (сюнну) ведутся более ста лет, однако информации о захоронениях высшей сюннуской знати по-прежнему крайне недостаточно. Чтобы частично восполнить этот пробел, была проведена Забайкальская экспедиция. Институт истории материальной культуры РАН в полевых сезонах 19982005 гг. проводил систематические работы на одном из могильников сюнну в пади Царам (Кяхтинский р-н Республики Бурятия, в 1.5 км южнее поселка Наушки). Впервые захоронения в пади Царам были обнаружены в июне 1899 г. известным исследователем Забайкалья Ю.Д. Талько-Грынцевичем, который зафиксировал не менее 20 могил, "рассеянных по лесу". Пять из них в июне 1903 г., были раскопаны им совместно с Я.С. Смолевым. Все могилы были ограблены, полученные находки крайне немногочисленны: железное шило с кольцеобразным навершием, фрагмент бронзовой накладки и фрагменты нескольких сосудов. Особенности внутримогильных конструкций позволили Ю.Д. Талько-Гринцевичу отнести эти погребения к выделенному им типу "захоронений в срубах", которые он интуитивно правильно отождествлял с погребениями азиатских гуннов - хунну или сюнну [5, с. 93, 117, 118].

Результаты детального обследования, проведенного Забайкальской экспедицией ИИМК РАН, топографический план и данные обмеров намогильных сооружений памятника показали, что в пади Царам сосредоточены одни из наиболее крупных среди известных ныне погребальных сооружений сюнну. Вполне очевидно, что в пади Царам находилось элитное кладбище высшей сюннуской знати, погребальные сооружения которой до недавнего времени оставались практически неисследованными. Работы экспедиции в пади Царам были спланированы с учетом особенности планиграфии сюннуских могильников, которая демонстрирует отчетливую тенденцию к размещению захоронений в погребальных комплекcax, состоящих из центрального кургана и расположенных вокруг него по определенной системе сопроводительных захоронений. Ряд данных позволяет сделать вывод, что в таких захоронениях погребены лица, умершие насильственной смертью и, вероятно, «сопровождавшие» своего хозяина в потусторонний мир [1, с. 21-27]. Основные исследования проводились в северной части пади, где располагался один из крупнейших курганов сюнну, известных в настоящее время. Большие размеры кургана, сложная погребальная конструкция, обилие в инвентаре престижных изделий позволяют предположить, что он представляет собой захоронение одного из сюннуских вождей (шаньюев). Заложенный раскоп охватил как сам курган, так и площадь вокруг него, где, учитывая выходы отдельных 
камней, возможно, находились небольшие захоронения с разрушенной намогильной кладкой. Общая площадь раскопа составила 7700 м² . Кроме центрального кургана, на этом участке обнаружено и исследовано десять сопроводительных погребений со следами человеческих жертвоприношений. Они образовывали две линии - с западной и восточной стороны от кург. 7, - в каждой по пять захоронений, и, несомненно, представляли собой единый с этим объектом комплекс.

Материалы раскопок сопроводительных захоронений опубликованы [2]; в данной статье рассматриваются материалы исследования центрального кургана комплекса (в последовательной нумерации объектов могильника имеет порядковый номер 7). Работы на кургане позволили получить принципиально новые данные о погребальном обряде сюнну. Поверхность кургана 7 был выражен насыпью размерами 32×32 м, высотой ок. 1,5 м; в центре насыпи находилась западина глубиной 2,5 м. С южной стороны насыпи прослеживалось возвышение трапециевидной формы длиной 20 м, полого понижавшееся к югу. Все намогильное сооружение состояло из смеси гумусированной почвы, суглинка и супеси и было покрыто тонким слоем переотложенного желтого материкового суглинка. По периметру насыпь окружали невысокие стены - каменные плиты, поставленные вертикально в один два ряда. Некоторые такие же плиты, узкие и длинные, изначально использовались, видимо, как своеобразные стелы; они стояли вдоль северной и южной стенок кургана. Верхний контур могильной ямы практически совпадал с границами намогильного сооружения; размеры ямы по этому контуру составляли $29 \times 26,5$ м. В верхней части могильной ямы была расчищена внутримогильная конструкция, которую условно можно назвать деревянной клетью. Она состояла из сложенных один над другим сосновых бревень, которые образовывали одну продольную и семь перпендикулярных к ней перегородок. Продольная перегородка проходила через всю яму и дромос в направлении с севера на юг и разделяла яму и дромос на западную и восточную части. Поперечные перегородки располагались только в могильной яме асимметрично по отношению к продольной перегородке: четыре перегородки зафиксированы в западной половине могильной ямы и три - в восточной. В целом данная конструкция из одной продольной и семи поперечных перегородок делила верхнюю часть ямы на девять отсеков. При расчистке деревянной «клети» под бревнами второго уровня продольной перегородки на глубине 218 см от репера кургана были обнаружены десять фрагментов ханьского зеркала, лежавших шесть фрагментов один под другим и еще четыре - рядом с ними. Эти обломки не позволяют составить целое зеркало, но дают возможность реконструировать его размеры и орнамент. Можно предположить, что во время погребальной церемонии над рассматриваемым зеркалом совершался особый обряд, который, вероятно, был нормой погребальной практики сюнну в целом. В ходе этого обряда зеркало подвергалось механическому (или температурному) воздействию и раскалывалось. Один или несколько его фрагментов «сопровождали» 
умершего в потусторонний мир, другие части зеркала изымались и, возможно, хранились в семье или у родственников покойного [3].

Ниже деревянной «клети» были расчищены и зафиксированы четыре перекрытия могильной ямы. Верхнее перекрытие состояло из крупных каменных плит, уложенных на сосновые бревна, которые перекрывали всю могильную яму с севера на юг. Под бревнами находился слой тростника. Второе перекрытие располагалось ниже первого на 120-150 см и состояло из уложенных встык каменных плит, под которыми отмечен также слой тростника. Третье перекрытие было многослойным: крупные каменные плиты размерами в среднем $100 \times 70$ см, слой древесного угля и речной гальки, слой спрессованной березовой коры, мелких веток и шишек, слой крупной щебенки. Четвертое перекрытие было также многослойным: крупные каменные плиты размерами в среднем $80 \times 60$ см, слой спрессованной березовой коры, мелких веток и шишек, слой крупной речной гальки, слой крупного щебня, слой мелкого древесного угля. После расчистки третьего и четвертого перекрытий стали очевидными различия между их западной и восточной частями. Они проявились в цвете и структуре каменных плит: в западной части указанные перекрытия состояли из плит светло-серого песчаника, в восточной - из светло-розовых валунов.

При разборе третьего и расчистке четвертого перекрытий в центре кургана были обнаружены детали колесницы (тент, колеса, наосьники, втулки для колес, деревянные лакированные части дышла с орнаментом). Расположение этих деталей позволяет предположить, что колесница была поставлена в северной половине могильной ямы на плиты четвертого перекрытия и затем засыпана землей, вынутой при рытье ямы, а также щебнем, галькой, углем и покрыта плитами третьего перекрытия [4]. Сохранность деталей колесницы была чрезвычайно плохой - деревянные части и органический материал тента практически полностью сгнили, бронзовые и железные детали сильно окислились, многие из них утратили первоначальную структуру и сохранились фрагментарно. В центральной части могильной ямы прослеживались два грабительских хода, частично разрушивших центральную клеть, перекрытия и колесницу. Общая глубина могильной ямы от поверхности кургана составила 17 м. Внутримогильное сооружение состояло из тройной погребальной камеры (наружный сруб, внутренний сруб и гроб), заключенной в саркофаг из крупных каменных плит; четвертое перекрытие ямы фактически служило каменной крышей такого саркофага. Стенки наружной камеры образовывали брусья, сложенные в семь венцов; общая высота камеры ок. 170-180 см. Продольные и поперечные брусья соединялись между собой способом в замок, при этом врезы для соединения делались сплошными, на всю высоту бруса. Дополнительных креплений венцов брусьев между собой не зафиксировано. Потолок камеры состоял из досок, расположенных в направлении запад - восток. Доски шириной 20-35 см были положены встык; каких-либо приспособлений для скрепления их между собой или с 
верхними венцами камеры не обнаружено. Доски потолка опирались по краям на верхние венцы сруба, а в середине - на три потолочные балки, которые располагались по линии север - юг на равном расстоянии друг от друга. Потолочные балки опирались на верхние венцы камеры, имевшие специальные врезы для крепления балок, и на колонны, установленные вдоль северной и южной стенок с внутренней стороны камеры.

В северной части погребального сооружения вдоль стенки наружной камеры находились три колонны, еще три колонны - параллельно первым вдоль северной стенки внутреннего сруба. Вдоль южной стенки камеры располагались еще три аналогичные колонны. Таким образом, каждая из трех потолочных балок наружной камеры имела пять точек опоры: две - на северном и южном верхних венцах камеры (где концы балок вставлялись в специальные врезы), две - на северных и одну - на южных колоннах. Наружная камера стояла на полу из досок, уложенных по линии запад - восток. Доски пола опирались концами на деревянные «слеги», располагавшиеся у стенок могильной ямы с западной и восточной стороны. Внутренний сруб сложен из пяти квадратных в сечении брусьев (размеры 20×20 см). Продольные и поперечные брусья были соединены друг с другом в замок, аналогично венцам наружной камеры. Как и наружная камера, сруб имел перекрытие из поперечных досок и дощатый пол также из поперечных досок. Гроб, находившийся внутри сруба, был в значительной степени разрушен при создании южного грабительского хода и последующего обрушения камеры. Пол гроба и перекрытие предположительно состояли из двух продольных досок, каждая боковая стенка из широкой доски. Основной погребальный инвентарь размещался в наружных (между стенками ямы и камеры) и внутренних (между стенками сруба и гроба) коридорах. В результате обрушения внутримогильного сооружения и мещения венцов камеры и сруба многие комплекты инвентаря были деформированы и раздавлены; железные предметы (в основном детали конской сбруи) сильно окислились. Большую часть таких комплектов разобрать в полевых условиях не удалось. Северный наружный коридор в значительной степени был разрушен при создании грабительского хода; здесь найдены только фрагменты керамики и лакированных деревянных предметов, железного предмета, а также отдельные кости животных, покрытые окислами бронзы. Находки в западном наружном коридоре представлены скоплением железных предметов и двумя погребальными куклами с сопутствующим им инвентарем. В северо-западном углу коридора зафиксировано скопление железных предметов, включавшее, вероятно, железные удила и псалии, а также другие предметы, полностью покрытые соединившимися между собой окислами. В стенках наружной камеры отмечены железные крюки; возможно, на них висели уздечные наборы, которые оказались на полу после деформации камеры. В центре западного коридора найдена погребальная кукла (кукла 1, северная). Ее голова изготовлена из черепа, судя по молочным зубам, ребенка 2-4 лет. На черепе куклы сохранились шесть кос из черного жесткого во- 
лоса, которые, вероятно, были прикреплены с помощью какого-либо клейкого вещества. Рядом с косами на черепе были подвески из золотой фольги с бирюзовыми вставками. Еще две косы находились перед и за черепом и две косы - в области пояса рядом с железными пластинами. Длинные конечности куклы моделировались в виде деревянных палочек, покрытых красным лаком. Погребальный инвентарь куклы 1 состоял из двух разложившихся железных пластин пояса размерами 15×6 см (кожаная основа пояса находилась рядом с пластинами) и расположенной за головой куклы лакированной деревянной шкатулки, рядом с которой обнаружено четыре берестяных туеска (не исключено, что первоначально они были внутри шкатулки. Шкатулка покрыта красным лаком и по краям украшена аппликацией: геометрический узор из красного лака был наклеен на полосы желтого лака. Под шкатулкой обнаружена заколка для волос из органического материала (возможно, из черепашьего панциря). Под берестяными туесками лежал берестяной круг, на котором найден фрагмент бронзового китайского зеркала. На одном из берестяных туесков изображено стойбище сюнну с юртами на колесах, на другом сохранилось профильное изображение головы человека в шлеме - вероятно, копия какойлибо монеты. Сходным образом была смоделирована и другая кукла (кукла 2), обнаруженная в западном коридоре. Она лежала в 1 м южнее куклы 1. Основу куклы 2 также составлял человеческий череп, который полностью разложился. Сохранились лишь мелкие молочные зубы; их состояние позволяет предположить, что череп принадлежал младенцу в возрасте нескольких месяцев. За черепом лежала короткая коса из жестких черных волос. Верхних конечностей не зафиксировано, нижние конечности были сделаны из тонких железных пластин, помещенных в деревянный футляр и покрытых красным лаком. Ниже черепа куклы 2 найдено ожерелье из стеклянных, бирюзовых, флюоритовых и крупных хрустальных бусин. В области пояса куклы отмечены две истлевшие железные пластины размерами $20 \times 11$ см; пластины лежали на кожаной основе пояса, которая сохранилась фрагментарно и местами была покрыта красным лаком. От кожаного пояса спускалась низка бусин, основу которой составляли практически полностью разложившиеся стеклянные бусины. Обнаружены также сердоликовые, флюоритовые и янтарные бусины. Ниже пояса куклы 2 под сместившимся венцом наружной камеры отмечены остатки раздавленного деревянного лакированного сосуда с геометрическим орнаментом. Внутри его находились фрагмент бронзового китайского зеркала, кусочек слюды, два деревянных гребня и набор железных игл в деревянном футляре. На внешней поверхности сосуда сохранилась иероглифическая надпись с названием изготовившей его мастерской. Особенности начертания иероглифов и стиль орнамента позволяют считать, что сосуд был изготовлен между 8 г. до н.э. и 4 г. н.э. Находки из восточного и западного наружного коридоров практически аналогичны. В северной части коридора обнаружено скопление полностью окисленных железных предметов, вероятно, удил, псалий, пряжек. Погребальная кукла (кукла 
3), лежавшая в середине восточного коридора южнее деталей сбруи, была смоделирована так же, как и куклы из западного наружного коридора. Череп куклы практически полностью сгнил. В области черепа лежало несколько кос из жесткого черного волоса. На кончиках кос прослеживались бирюзовые, стеклянные и янтарные бусинки. Конечности были смоделированы из деревянных лакированных палочек. В области шеи справа и слева от черепа зафиксированы остатки двух круглых подвесок из дерева, покрытых лаком. Не исключено, что эти подвески были изготовлены из стенок деревянных лакированных чашечек. На поясе куклы 3 находились две широкие окисленные железные пряжки размерами $19 \times 12$ см. За головой куклы обнаружены остатки деревянного предмета (возможно, шкатулки), на них - маленький берестяной туесок и крупный фрагмент китайского зеркала. Южнее куклы 3 в восточном коридоре 2-х метровое свободное пространство, за ним находились кости стоп человека. По всей вероятности, здесь лежала еще одна кукла (или труп человека), которая практически полностью была извлечена грабителями. В юго-восточном углу коридора под смещенными бревнами наружной камеры обнаружены окисленные железные бляшки.

Южный наружный коридор был полностью перекрыт смещенными бревнами камеры и сруба. Находок в коридоре не было, лишь на стенках наружной камеры с внутренней стороны фиксировались мелкие кусочки шелка и остатки шерстяного ковра. Находки в северном внутреннем коридоре, полностью разрушенном грабителями, отсутствовали. В западном внутреннем коридоре у юго-западного и юго-восточного углов гроба зафиксированы только два бронзовых поручня гроба. Поручни длиной 40 см и диаметром 4 см цилиндрической формы, с небольшими утолщениями на концах. В восточном внутреннем коридоре остатки инвентаря сохранились только в южной части; северная часть коридора была разрушена при сооружении южного грабительского хода. В юго-восточном углу коридора обнаружено скопление окисленных железных предметов, среди которых можно предположительно различить удила, псалии, а также несколько железных трех первых наконечников стрел. Далее к северу вдоль стенки сруба находились два серебряных фалара с изображением горного козла. Западнее фаларов лежал целиком сохранившийся деревянный посох. Его длина 153 см, диаметр 4 см; окончание посоха плоское, навершие выполнено в виде резного шара. Посох покрыт темно-коричневым лаком с орнаментом в виде коротких волнистых линий, нанесенных красным лаком. Под рукоятью посоха лицевой стороной вниз лежала бронзовая бляха с изображением горного козла в прыжке. Ниже посоха найдена деревянная лука седла. Она состояла из трех пластин трапециевидной формы, лежавших в виде буквы П. На коротких сторонах пластин имелось несколько отверстий для скрепления пластин между собой. Ниже луки седла под слоем разложившейся кожи - фрагменты серебряных блях с изображением козла в прыжке, идентичным изображению на бронзовой бляхе. Около нижней части посоха найдены коса из плотного волоса каштанового цвета и лакированная деревянная чашечка, рядом с которой ле- 
жал небольшой железный черпачок. В юго-восточном углу южного внутреннего коридора обнаружены плоское железное кольцо и две железные скобы. Как отмечалось, северная часть гроба была разрушена южным грабительским ходом. У северо-восточного угла гроба, с наружной стороны, лежала верхняя часть черепа козла, покрытая серебряной фольгой. В сохранившейся южной части гроба найдены остатки покрытия из органического материала (войлок или спрессованный мех). После расчистки этого покрытия в центре гроба у края грабительского хода были обнаружены две золотые пронизки с изображением горного козла, маленький сосуд из золота грушевидной формы также с изображением горного козла (горловина сосуда закрыта деревянной пробкой) и остатки ритуального меча в деревянных лакированных ножнах. Изображения животного на пронизках и сосуде полностью аналогичны. Голова и ноги козла изображены рельефно, глаза, туловище и хвост показаны бирюзовыми вставками. У южной стенки гроба находились две пряжки из железа, покрытые золотой фольгой. Прямоугольные наконечники ремешков из железа, также с золотой фольгой, лежали между пряжками. Пряжки размерами 7,5×5,0 см имеют форму усеченного овала. На лицевой стороне пряжек видно изображение мистического существа, которого условно можно назвать сатиром. Морда «сатира» показана рельефно, глаза, брови и усы исполнены в виде агатовых вставок, основания рогов и заколка в волосах подчеркнуты бирюзовыми вставками. В пасти одного «сатира» сохранились остатки ремешка из ткани. На границе грабительского хода и разрушенной части гроба найдены фрагменты диадемы из белого нефрита и обломки пластин с отверстиями (возможно, от парадного панциря) также из белого нефрита. Типология погребального инвентаря, наличие фрагментов ханьских зеркал в заполнении могильной ямы и в инвентаре кукол, особенности надписи на лакированной шкатулке, а также сведения письменных источников позволяют датировать комплекс № 7 в пределах I в. н.э., вероятно, первой его половины [2, 3, 4$]$.

Благодаря подробному описанию археологического памятника С. С. Миняевым, становится понятным его монументальность и большая значимость для истории и материальной культуры в целом. Сергей Степанович предположил: учитывая большие размеры кургана, монументальность погребальной конструкции, а также обилие среди инвентаря (несмотря на то, что объект дважды подвергался разграблению) престижных золотых, серебряных и лакированных предметов, в кургане был захоронен один из представителей высшей знати сюнну, возможно, один из сюннуских вождей (шаньюев).

Проведенные археологические раскопки ИИМК РАН, под руководством С.С.Миняева дают возможность наиболее детально изучить жизнь и быт азиатских гуннов (сюнну, хунну). 


\section{Примечания}

1. Миняев С.С. К топографии курганных памятников сюнну // КСИА. - 1985. - Вып. 184. - С. 21-27.

2. Миняев С.С., Сахаровская Л.М. Сопроводительные захоронения «царского» комплекса № 7 в могильнике Царам // Археологические вести. - СПб.: Дм. Булавин, 2002. - № 9. - С. 86-118.

3. Миняев С.С., Сахаровская Л.М. Ханьское зеркало из могильника Царам // Зап. ИИМК РАН. - СПб.: Дм. Булавин, 2006. - Вып. 1. - С. $77-82$.

4. Миняев С.С., Сахаровская Л.М. Ханьская колесница из могильника Царам // Археологические вести. - М.: На- ука, 2007. - Вып. 14. - С. $130-140$.

5. Талько-Гринцевич Ю.Д. Материалы к палеоэтнологии Забайкалья. - СПб.: Фонд «Азиатика», 1999. - 123 с. - (Археологические памятники сюнну; вып. 4).

\section{References}

1. Minyaev S. S. K topografii kurgannykh pamyatnikov syunnu [To the topography of the burial monuments of the Huns] // KSIA [SRIA]. - 1985. - Issue. 184. - Pp. 21-27. [In Russ.].

2. Minyaev S. S., Sakharovskaya L. M. Soprovoditel'nye zakhoronenija "tsarskogo" kompleksa №7 v mogil'nike Tsaram [Escorting the burial of the "Royal" complex No. 7 in Tsaram cemetery] // Arkheologicheskije novosti [The archaeological news]. - S.-P., 2002 . - № 9. Pp. 86-118. [In Russ.].

3. Minyaev, S. S., Sakharovskaya L. M. Khan'skoe zerkalo iz mogil'nika Tsaram [The khan mirror from the burial Tsaram] // Zap. IIMK RAS [The notes of the IHMC RAS]. - S.-P., 2006. - Issue. 1. - Pp. 77-82. [In Russ.].

4. Minyaev, S. S., Sakharovskaya L. M. Khanskaja kolesnitsa iz mogil'nika Tsaram [The khan's chariot from the burial Tsaram] // Arheologicheskie novosti [The archaeological news]. - M., 2007. - Issue. 14. - Pp. 130-140. [In Russ.].

5. Talko-Gryntsevich Yu. D. Materialy dlya paleoetnologii Zabaikal'ja [The materials for paleoethnology of Transbaikalia]. - S.-P., 1999. - 123 p. (Archaeological sites of the Syuns; vol. 4). [In Russ.]. 
DOI 10.31443/2541-8874-2019-2-10-15-19

УДК 94(571.5)+614.47

Цыремпилов Д.В.

Tsyrempilov D.V.

\section{ФОНД № 159 «ВЕРХНЕУДИНСКИЙ ОКРУЖНОЙ ОСПЕННЫЙ КОМИТЕТ» КАК ИСТОЧНИК ПО ИСТОРИИ ОСПОПРИВИВАНИЯ В ВОСТОЧНОЙ СИБИРИ ХІХ в. \\ FUND NO. 159 "THE VERKHNEUDINSK DISTRICT SMALLPOX COMMITTEE" AS A SOURCE ON THE HISTORY OF SMALLPOX VACCINATION IN EASTERN SIBERIA IN THE XIX ${ }^{\text {th }}$ CENTURY}

В статье исследуются особенности государственной политики в области медицины по предотвращению эпидемий оспы в Восточной Сибири XIX в. На основе архивного материала выявлены основные направления деятельности по борьбе с распространением оспы в Восточной Сибири во 2-ой половине XVIII-XIX вв.

The article considers the features of the state policy in the field of medicine, namely in prevention smallpox epidemics in Eastern Siberia in the $X^{X I X^{\text {th }}}$ century. The main activities to combat the spread of smallpox in Eastern Siberia in the second half of the XVIII ${ }^{\text {th }}$-XIX ${ }^{\text {th }}$ centuries are revealed on the basis of the archival materials.

Ключевые слова: оспопрививание, прививки, оспопрививатели, оспенные ученики, ламы, лекари, крестьяне, национальные кадры, вакцинация.

Keywords: smallpox vaccination, vaccination, the people vaccinating against smallpox, local people selected to be taught smallpox vaccination, lamas, healers, peasants, national staff.

Оспопрививание стало в дореволюционный период одной из приоритетных задач развития государственного здравоохранения в Забайкалье, так как эпидемии натуральной оспы приводили к большим человеческим жертвам.

Ни один губернаторский отчет или отчет городской думы не обходился без доклада о положении оспопрививания. Впервые в Западном Забайкалье (ныне Республика Бурятия) оспопрививание было проведено в 1770 г. в Баргузине врачом Иваном Гришиным.

Первым оспопрививателем в городе Верхнеудинске в конце XVIII в. стал врач И.Ф. Ресслейн. Отметим, что в тот период вакцинация не носила системного характера и проводилась врачами-энтузиастами, использовавшими метод вариоляции - активной иммунизации против натуральной оспы путем введения здоровым людям содержимого оспенных пузырьков больных людей. 
В 1772 г. по результатам представления иркутского губернатора Адама Ивановича Бриля, занимавшего эту должность с 1767 по 1776 гг., из-за высокой смертности от эпидемий оспы был открыт Иркутский оспенной дом [2, л. 38]. В то время детей тщательно готовили к прививке оспы (проводили очищение кишечника, дегельминтизацию, создавая благоприятную гигиеническую обстановку) и тщательно наблюдали за их общим состоянием в течение нескольких недель после прививки. В 1776 г. в Иркутском оспенном доме были привиты 6450 бурятских детей, 28 из которых умерли [2, л. 57].

В 1808 г. правительство России приняло постановление о массовом оспопрививании коренного бурятского населения. В том же году, для того чтобы подготовить соответствующих специалистов, из жителей Хоринского ведомства отобрали 19 «умных и способных лиц» и отправили в российские лекарские школы. Во время учебы они находились на полном казенном содержании. Получив необходимые знания, лекари возвращались на родину и начинали делать прививки своим землякам. В то время широкое распространение получила идея подготовки национальных кадров для этих целей, т.к. люди, говорящие на одном языке, лучше понимают друг друга. На учебу были направлены представители 8-ми селенгинских родов, принадлежавших к буддийской религии - ламы из Гусиноозерского и Сонгольского дацанов. Вероятно, такое решение было обусловлено наличием определенной медицинской подготовки у лам, а также большим доверием коренного населения к служителям дацанов [1, л.125-132].

Вакцинацию также проводили оспенные ученики из крестьян. Сначала кандидат на должность оспенного ученика выбирался и утверждался общественным приговором его ведомства. К выбору в оспенные ученики предъявлялись высокие требования. В общественном приговоре от 8 сентября 1860 г. от всех селений Куналейской волости Верхнеудинского округа читаем: «Избранный нами в оспенные ученики крестьянин с. Малетинского Симеон Спиридонович Меринов веры православной, знающий грамоту, к другим скопческим и раскольническим сектам не принадлежит, ..., ни к какому суду как то за растрату казенных и общественных сумм и по уголовным делам и преступлениям судим не был, и ныне под судом не состоит, возложенную на него должность исправлять может, и он поведения хорошего и ни в каких худых поступках замечен не был, имеет домообзаведение, скотоводство, хлебопашество, по занятиям усерден. На выбор означенного крестьянина в оспенные ученики общество всей волости иметь его согласны без всякого препятствия и пререкания» $[10$, л. 53, 53об.].

Особое внимание обращалось на образование оспопрививателей. В общественном приговоре крестьян Куналейской волости от 8 июня 1860 г. говорится: «...о том, чтобы штатные оспопрививатели недопускались безграмотные и если в настоящее время таковые находятся оспопрививателями, то их заменить немедленно другими грамотными» [10, л. 56].

Кроме этого, после обучения, кандидат на звание оспопрививателя 
должен был пройти испытание и утверждение в должности в Верхнеудинском оспенном комитете. В протоколе заседания от 27 февраля 1857 г. Верхнеудинского окружного оспенного комитета находим: «...для обучения к оспопрививанию передать командированному оспенному ученику Крюкову, а по обучении прислать в оспенный комитет для испытания и утверждения в звании оспопрививателя... Приказали: «О сем записать в журнале, а крестьянина с. Захаровского Ефима Решетникова утвердить в звании оспенного ученика, о чем дать знать Урлукскому волостному правлению с тем, чтобы оно по обучении Решетникова к оспопрививанию для испытания представило в сей комитет» [7, л. 5 об.; 6,6 об.].

«Оспопрививательных учеников», как их тогда называли, освобождали от различных повинностей, например: «За избранного в оспенные ученики крестьянина Меринова подати и повинности на основании применения к 56 ст. по 4 пункту Высочайше утвержденных правил 13 июля 1851 г. нового устройства земских повинностей должны платить крестьяне Малетинского общества...[10, л. 53об.]. А также предоставляли им для работы транспорт - верховых лошадей и подводы. В донесении Верхнеудинского окружного врача Стацкевича говорилось: «Для поверки оспопрививания по Иволгинскому отдельному обществу и в г. Селенгинске командирован мною Верхнеудинский оспенный ученик Орлов, почему честь имею покорнейше просить Оспенный комитет выдать еще Орлову открытое предписание для взимания междудворных подвод от г. Верхнеудинска по всему Иволгинскому отдельному обществу и обратно» ... [3, л.; 1,1 об.].

Они получали соответствующее жалование и были полностью освобождены от повинностей. Например, служивший с 1848 г. оспопрививателем в Малочитканском селении Читканской волости Баргузинского округа Карп Нефедьев Галицкий получал жалованье из Верхнеудинского окружного казначейства из сбора земской повинности 22 руб. 85 коп. серебром, сверх сего довольствовался от общества пахотной и сенокосной землей и освобождался от платежа податей, который ложился на все крестьянское общество. К.Н. Галицкий с 1848 г. привил от оспы 2660 детей $[6$, л. 3об.,4]. В селениях Баянхосунского отдельного общества оспенными учениками Яковом Шлыковым и Евдокимом Вершининым было привито 74 ребенка. В селениях Кударинской степной думы в родах 1-го Чернорудского, 2-го Чернорудского, Абзаевского и Сборного было привито 9 детей оспенными учениками Ивановым и Горбуновым [12, л.26 об., 27].

В Селенгинском ведомстве было 12 оспопрививателей, состоящих в ведении Верхнеудинского оспенного комитета на 1863 г.: 1) Олзонова рода - Чагдур Цыбенов, 2) Селенгинскохаранутского рода - Ванбу Дашиев, 3) Табангутского рода - Рабдан Ленхоев, 4) Бумолгутульского рода Дагба Цыденжапов, 5) Ашебагатского рода - Шарап Банзаракцаев, 6) Цонголова рода - Юндун Чойнжилов, 7) Цонголова рода - Гатаб Дылыков 8) 1-го Атаганова рода - Цыван Бунбунов, 9) Сартолова рода - Лыгжит Гармаев, 10) Иринско-Харанутского рода - Цыдендамба Будариев, 
11) Хатагинова рода - Чойроп Сандуев, 12) Чикойско-харанутского рода - Данзан Ямпилов.

С начала их деятельности по 1-ую половину 1863 г. ими было привито 5178 детей [5, 46 об., 47]. В Хоринском ведомстве во всех 11 родах за 1863 г. было привито 352 ребенка. В ведомстве состояло в ведении Верхнеудинского оспенного комитета 15 оспенных учеников: 1) Бату Аюшиев, 2) Жамбалдоржи Бадмаев, 3) Дамшой Сакинаев, 4) Самдан Бакшиев, 5) Тогмид Дылгыров, 6) Цыренпил Петруев, 7) Очир Шатуев, 8) Жинба Занов, 9) Бадма Саржиев, 10) Ринчин Богадаев, 11) Гарма Бандуев, 12) Ванпил Зодбоев, 13) Содбо Очиров, 14) Тарба Китасов, 15) Тушимил Санакиев [6, л. 47 об., 48].

За успехи в оспопрививании оспопрививатели награждались медалями. Например, оспенный ученик Селенгинского ведомства Хатагинова рода Чойроп Сандуев был усерден в течение 25 лет в оспопрививании и привил 2110 детей от оспы, за это имел благодарность от Селенгинской степной думы, а также имел высочайшую награду - серебряную медаль для ношения в петлице на Станиславской ленте [5, л. 46 об., 47].

Точной даты начала работы Верхнеудинского окружного оспенного комитета в документах фонда не имеется. Верхнеудинский окружной оспенный комитет имел следующий состав: Председатель - Верхнеудинский Городничий Надворный Советник Андрей Матвеевич Плотников. Члены: Верхнеудинский Благочинный Протоиерей Харлампий Попов, Земский Исправник Коллежский Секретарь Алексей Николаевич Соколовский, Верхнеудинский Окружной Врач Коллежский Ассесор Павел Матвеевич Стацкевич, Городовой судья купец 3-й гильдии Афанасий Иванович Налетов [11, л. 2].

В журнале заседаний Верхнеудинского окружного комитета имеются доклады степных дум об утверждении, увольнении и замене оспенных учеников по причине болезни, уходе на другую должность, а также недостаточной работы по оспопрививанию [7, л. 5 об., 6,6 об.]. Также комитет проводил проверки оспопрививания, например, член комитета верхнеудинский окружной врач Павел Стацкевич докладывал в комитет об упущениях по оспопрививанию в Кульском обществе и просил командировать для поверки оспопрививания по всем селениям общества лекарского ученика Демидова [4, л. 13, 13 об., 14].

Отдельной большой проблемой для оспенного комитета, которая отражалась в журналах заседаний, являлся отказ старообрядческого населения от оспопрививания. Причиной отказа была религиозная и бытовая замкнутость местного населения. Например, в протоколе заседания от 31 июля 1860 г. говорится о постоянных мерах к убеждению староверов к принятию предохранительных прививок от оспы Земской полицией, а также о том, что строгие полицейские меры по смыслу закона приняты быть не могут.

Кроме этого и ранее никакие меры ни кроткие, ни строгие не действовали, а потому поездка верхнеудинского окружного врача в этом 
предприятии будет безуспешна [9, л. 1, 1 об.,]. Помимо этого, Верхнеудинский оспенный комитет снабжал Забайкальский оспенный комитет свежим оспенным материалом [8]. Оспопрививатели обязаны были доставлять месячные и полугодовые ведомости об оспопрививании в Верхнеудинский окружной оспенный комитет $[10$, л. 56].

Таким образом, благодаря систематическим правительственным мероприятиям и планомерным усилиям медицинского персонала, у населения Забайкалья удалось сформировать позитивное отношение к оспопрививанию и создать устойчивое понимание того, что вакцинацию необходимо проводить во всех возрастных группах населения.

\section{Примечания}

1. Батоев С. Д. Оспопрививание в Забайкалье (XVIII - начало XX в.) // История медицины. 2016. Т. 3, № 2.131 с. 16. Д. 22.

2. Государственный архив Республики Бурятия (ГАРБ). Ф.11. Оп.

3. ГАРБ. Ф.159. Оп.1. Д. 35.

4. ГАРБ. Ф. 159. ОП. 1. Д. 41.

5. ГАРБ. Ф.159. Оп. 1. Д. 44.

6. ГАРБ. Ф.159. ОП. 1. Д. 45.

7. ГАРБ. Ф.159. Оп. 1. Д. 69.

8. ГАРБ. Ф.159. ОП. 1. Д. 80.

9. ГАРБ. Ф. 159. ОП. 1. Д. 81.

10. ГАРБ. Ф. 159. ОП. 1. Д. 82.

11. ГАРБ. Ф. 159. Оп. 1. Д. 83.

12. ГАРБ. Ф. 159. ОП. 1. Д. 86.

\section{References}

1. Batoev S.D. Ospoprivivanije v Zabajkal'je (XVIII - nachalo XX v.) [Smallpox vaccination in the Transbaikal region (XVIII - beginning of the $\mathrm{XX}^{\text {th }}$ century)] // Istorija mediciny [The history of Medicine]. 2016. V. 3. № 2. 131p. [In Russ.]

2. Gosudarstvenny arkhiv Respubliki Buryatija (GARB) [The state archive of the Republic of Buryatia (SARB]. F.11. Inv.16. C.22 [In Russ.]

3. GARB. F.159. Inv.1. C. 35 [In Russ.]

4. GARB. F. 159. Inv. 1. C. 41 [In Russ.]

5. GARB. F.159. Inv. 1. C. 44[In Russ.]

6. GARB. F.159. Inv. 1. C. 45 [In Russ.]

7. GARB. F.159. Inv.1. C. 69 [In Russ.]

8. GARB. F.159. Inv. 1. C. 80 [In Russ.]

9. GARB. F. 159. Inv. 1. C. 81 [In Russ.]

10. GARB. F. 159. Inv. 1. C. 82 [In Russ.]

11. GARB. F. 159. Inv. 1. C. 83 [In Russ.]

12. GARB. F. 159. Inv. 1. C. 86 [In Russ.] 
DOI 10.31443/2541-8874-2019-2-10-20-24

УДК 94(571.54)+656.8

Хамаева Е.Д.

Khamaeva Ye.D.

ДЕЯТЕЛЬНОСТЬ ТРОИЦКОСАВСКОЙ ПОЧТОВО-

ТЕЛЕГРАФНОЙ КОНТОРЫ В КОНЦЕ ХІХ-ХХ ВВ.

В ДОКУМЕНТАХ ГОСУДАРСТВЕННОГО АРХИВА

РЕСПУБЛИКИ БУРЯТИЯ

\section{THE ACTIVITIES OF TROITSKOSAVSK POST AND TELEGRAPH OFFICE AT THE END OF THE $\mathrm{XIX}^{\text {th }}-\mathrm{XX}^{\text {th }}$ CENTURIES IN THE DOCUMENTS OF THE STATE ARCHIVE OF THE REPUBLIC OF BURYATIA}

В статье рассматривается деятельность Троицкосавской почтовотелеграфной конторы в конце XIX - начале XX вв. в документах Государственного архива Республики Бурятия.

The article considers the activities of the Troitskosavsk post and telegraph office at the end of the $\mathrm{XIX}^{\text {th }}$ - beginning of the $\mathrm{XX}^{\text {th }}$ centuries in the documents of the State archive of the Republic of Buryatia.

Ключевые слова: почта, телеграф, посылка, бандероль, телеграмма, корреспонденция, телефонная сеть.

Keywords: mail, telegraph, parcel, telegram, correspondence, telephone network.

По мере развития человеческого общества возрастала потребность в более быстрых и надежных средствах связи, способных передавать информацию в больших объемах. Это обусловило появление вначале почты, а в XIX веке - телеграфа. История средств и способов передачи информации была и остается социально значимой темой. История почты неразрывно связана с историей России и является показателем уровня общественного развития. Расширяя возможности информационных коммуникаций, почтовая связь способствует дальнейшему росту экономики, культуры и просвещения в государстве.

Почтово-телеграфные конторы образованы в конце XIX - начале $\mathrm{XX}$ вв. путем объединения почтовыХ контор и телеграфных станций. Почтово-телеграфные и почтовые учреждения делились, как и прежде, на следующие разряды: конторы и отделения. Почтово-телеграфные конторы были шести классов, а отделения - постоянные и временные.

Кяхтинская телеграфная станция была открыта в 1875 году. В 1885 году имела 3 разряд, а в 1889 году преобразована в телеграфную контору 4 класса [5, л.1 об.;14, л. 29].

В документах фонда «Троицкосавской почтово-телеграфной конторы» встречаются другие названия Троицкосавской почтово-телеграф- 
ной конторы: Кяхтинская телеграфная станция в 1876 году [2]; Кяхтинская телеграфная контора в 1889 году [14, л. 29]; Троицкосавская почтово-телеграфная контора в 1904 году [19]; Троицкосавская телефонная сеть в 1917 году [15].

В функции почтово-телеграфной конторы входило: обслуживание административных и военных учреждений, прием и передача почтовых отправлений и телеграмм, хранение и пересылка местной, иногородней и междугородней корреспонденции.

В структуру Троицкосавской почтово-телеграфной конторы входили следующие отделы: посылочный, заказной, простой и канцелярия [12, л.50, 51].

В 1900 году в штатный состав почтово-телеграфной конторы входили: начальник конторы, почтово-телеграфные чиновники 4, 5 разрядов - 2 единицы, чиновник 6 разряда - высшего оклада, чиновник 6 разряда низшего оклада -2 единицы и сторож [9, л.18 об.].

В 1914 году в штатную численность входили и их функции:

1) заведующий конторой следил за телеграфным и почтовым делом, принимал почтовые и телеграфные сборы, проверял все документы по телеграфной отчетности, хранил излишки переводных сумм и ценностей до отсылки по назначению;

2) исполняющий обязанности помощника начальника конторы чиновник 2 разряда принимал и выдавал переводы, вскрывал и проверял вещи, был ответственным за склад вещей;

3) почтово-телеграфные чиновники 2 разряда - 2 единицы занимались ведением книг, подборкой и брошюровкой всех документов, выписывали повестки на все виды денежных переводов, посылок и бандеролей;

4) заведующий посылочным отделом - чиновник 4 разряда производил прием и выдачу посылок и заказных бандеролей с наложенным платежом, составлял документы, реестры с препровождением декларации в таможню на заграничные посылки, вел ведомость путевого довольствия почтальонам;

5) заведующий заказным отделом - чиновник 5 разряда производил прием и выдачу заказной корреспонденции, продавал знаки почтовой оплаты, гербовых марок;

6) заведующий простым отделом - чиновник 5 разряда производил вскрытие и сортировку простой корреспонденции, очистку городских ящиков, контролировал действия «письмоновцев»;

7) заведующий канцелярией - чиновник 6 разряда исполнял всю текущую переписку, составлял месячную и годовую отчетность, заведовал архивом, занимался подсчетом почтовых и телеграфных сборов [12, л. 50, 51].

Троицкосавская почтово-телеграфная контора подчинялась Управлению Иркутского телеграфного округа [1], с 1886 года - Управлению Забайкальского почтово-телеграфного округа [6], затем Управлению Забайкальского округа народной связи [18]. 
Начальнику Троицкосавской почтово-телеграфной конторы подчинялись ближайшие почтовые отделения Забайкальской области. В 1876 году заведующий станцией был телеграфист 2 разряда Франц Людок [2, л. 6], в 1900 году - А. Игумнов [10], в 1909 году - Б. Гантимуров [11, л.15], в 1916 году - И. Зданович [13], в 1919 - А. Козлов [17].

В Троицкосавской почтово-телеграфной конторе передавались тарифные и бесплатные телеграммы. Виды тарифных телеграмм: высочайшие, административные, коммерческие, газетные и разные. Телеграммы делились по категориям: без особого назначения, с доставкой, с уплаченными ответами, уплаченной проверкой, с извещением о доставке, с несколькими адресами, срочные. А также по числу слов: менее 5; от 5 до 10; от 11 до 15; от 16 до 20; от 21 до 30; от 31 до 40; от 41 до 50; свыше 50. Виды бесплатных телеграмм: высочайшие, телеграфные, метеорологические.

Отправка и получение внутренней корреспонденции в Троицкосавской почтово-телеграфной конторе в разные годы: $[2 ; 8 ; 11 ; 21]$.

\begin{tabular}{|c|c|c|c|}
\hline Год & $\begin{array}{c}\text { Исходящая кор- } \\
\text { респонденция }\end{array}$ & $\begin{array}{c}\text { Входящая коррес- } \\
\text { понденция }\end{array}$ & $\begin{array}{c}\text { Сбор } \\
\text { (в руб.) }\end{array}$ \\
\hline 1876 & 4215 & 4166 & 13610 \\
\hline 1886 & - & 8828 & 16374,25 \\
\hline 1894 & 8219 & 10302 & 14904,45 \\
\hline 1901 & 6423 & 7035 & 820,88 \\
\hline 1918 & 5191 & 5815 & 35625,90 \\
\hline
\end{tabular}

Международная корреспонденция [2; 7; 11;20]:

\begin{tabular}{|c|c|c|c|}
\hline Год & $\begin{array}{c}\text { Исходящая коррес- } \\
\text { понденция }\end{array}$ & $\begin{array}{c}\text { Входящая коррес- } \\
\text { понденция }\end{array}$ & $\begin{array}{c}\text { Сбор } \\
\text { (в руб.) }\end{array}$ \\
\hline 1876 & 48 & 58 & 1286,39 \\
\hline 1880 & 76 & 71 & - \\
\hline 1886 & 60 & 50 & - \\
\hline 1901 & 9 & 16 & - \\
\hline 1917 & 188 & 356 & - \\
\hline
\end{tabular}

В Троицкосавской почтово-телеграфной конторе происходил ежегодный обмен тарифных телеграмм с иностранными государствами. Имеются записи 1880 года: [3, л.7]

\begin{tabular}{|c|c|c|}
\hline Страна & Передано & Принято \\
\hline Австро-Венгрия & 2 & 1 \\
\hline Германия & 6 & 7 \\
\hline Турция & - & 1 \\
\hline Франция & 2 & 4 \\
\hline Китай & 66 & 58 \\
\hline
\end{tabular}


В 1883 году: [4]

\begin{tabular}{|c|c|c|}
\hline Страна & Передано & Принято \\
\hline Италия & 3 & 1 \\
\hline Германия & - & 1 \\
\hline Сингапур & - & 1 \\
\hline Китай & 78 & 69 \\
\hline Египет & - & 1 \\
\hline Северная Америка & 1 & - \\
\hline Франция & 2 & 3 \\
\hline Швейцария & 2 & 3 \\
\hline
\end{tabular}

Абонентская плата на телефонную сеть в Троицкосавской почтово-телеграфной конторе в 1912 году составляла (годовая, в рублях) [16, л. 111-112]:

- телефон основной семейного пользования - 50

- коллективный - 60

- слуховой прибор (трубка) - 3

В 1917 году:

- телефон основной семейного пользования - 100

- коллективный - 120

- слуховой прибор (трубка) - 6

В 1918 году:

- телефон основной семейного пользования - 240

- коллективный - 360

- слуховой прибор (трубка) - 12

В 1919 году на 1 октября:

- телефон основной семейного пользования - 720

- коллективный - 1080

- слуховой прибор (трубка) - 36

В 1920:

- телефон основной семейного пользования - 1200

- коллективный - 1800

- слуховой прибор (трубка) - 150 1920 года.

Троицкосавская почтово-телеграфная контора просуществовала до

Фонд «Троицкосавская почтово-телеграфная контора» представлен интересными документами, содержащими разнообразные сведения о деятельности Троицкосавской почтово-телеграфной конторы. Деятельность почтово-телеграфного учреждения была продуктивной, объемы передаваемой информации непрерывно росли на протяжении всего рассматриваемого периода.

\section{Примечания}

1. Государственный архив Республики Бурятия (ГАРБ). Ф.255. Оп.1. Д. 1

2. ГАРБ. Ф.255. ОП.1. Д. 2. 
3. ГАРБ. Ф.255. ОП.1. Д. 7.

4. ГАРБ. Ф.255. Оп.1. Д. 10.

5. ГАРБ. Ф.255. Оп.1. Д. 13.

6. ГАРБ. Ф.255. Оп.1. Д. 14.

7. ГАРБ. Ф.255. Оп.1. Д. 15.

8. ГАРБ. Ф.255. Оп.1. Д. 29.

9. ГАРБ. Ф.255. Оп.1. Д. 40.

10. ГАРБ. Ф.255. Оп.1. Д. 42.

11. ГАРБ. Ф.255. Оп.1. Д. 44.

12. ГАРБ. Ф.255. Оп.1. Д. 65.

13. ГАРБ. Ф.255. Оп.1. Д. 69.

14. ГАРБ. Ф.255. Оп.1. Д. 74.

15. ГАРБ. Ф.255. Оп.1. Д. 91.

16. ГАРБ. Ф.255. Оп.1. Д. 107.

17. ГАРБ. Ф.255. Оп.1. Д. 108.

18. ГАРБ. Ф.255. Оп.1. Д. 159.

19. ГАРБ. Ф.255. Оп.1. Д. 210.

20. ГАРБ. Ф.255. Оп.1. Д. 248.

21. ГАРБ. Ф.255. Оп.1. Д. 255.

\section{References}

1. Gosudarstvenny arkhiv Respubliki Buryatija (GARB) [The state archive of the Republic of Buryatia (SARB]. F.255. Inv.1. C.1 [In Russ.].

2. GARB [SARB]. F.255. Inv.1. C. 2. [In Russ.].

3. GARB [SARB]. F.255. Inv.1. C.7. [In Russ.].

4. GARB [SARB]. F.255. Inv. 1.C. 10. [In Russ.].

5. GARB [SARB]. F. 255. Inv.1. C.13. [In Russ.].

6. GARB [SARB]. F. 255. Inv.1. C.14. [In Russ.].

7. GARB [SARB]. F.255. Inv.1. C.15. [In Russ.].

8. GARB [SARB]. F.255. Inv.1. C.29. [In Russ.].

9. GARB [SARB]. F.255. Inv.1. C.40. [In Russ.].

10. GARB [SARB]. F.255. Inv.1. C.42. [In Russ.].

11. GARB [SARB]. F.255. Inv.1. C. 44. [In Russ.].

12. GARB [SARB]. F.255. Inv.1. C.65. [In Russ.].

13. GARB [SARB]. F.255. Inv. 1. C.69. [In Russ.].

14. GARB [SARB]. F.255. Inv.1. C. 74. [In Russ.].

15. GARB [SARB]. F.255. Inv.1. C. 91. [In Russ.].

16. GARB [SARB]. F.255. Inv.1. C. 107. [In Russ.].

17. GARB [SARB]. F.255. Inv.1. C. 108. [In Russ.].

18. GARB [SARB]. F.255. Inv.1. C. 159. [In Russ.].

19. GARB [SARB]. F.255. Inv.1. C. 210. [In Russ.]

20. GARB [SARB]. F.255. Inv.1. C. 248. [In Russ.].

21. GARB [SARB]. F.255. Inv.1. C. 255. [In Russ.]. 
DOI 10.31443/2541-8874-2019-2-10-25-37

УДК 069.015:378.4(571.16)

Матющенко О.И.

Matyushchenko O.I.

МУЗЕЙНЫЕ ПРЕДМЕТЫ СО ВСЕГО СВЕТА:

КАК КОМПЛЕКТОВАЛИСЬ ФОНДЫ МУЗЕЕВ

ИМПЕРАТОРСКОГО ТОМСКОГО УНИВЕРСИТЕТА

\section{MUSEUM OBJECTS FROM ALL OVER THE WORLD: HOW THE COLLECTIONS OF THE MUSEUMS FUNDS OF THE IMPERIAL TOMSK UNIVERSITY WERE COMPILED}

В статье представлен краткий обзор истории создания фондовых собраний Томского университета, выявлены главные тенденции деятельности музеев, характерные для периода 1882-1917 гг. В процессе разработки научного проекта выставки «Меценаты и первые коллекции музеев Императорского Томского университета» пришло понимание того, какая огромная работа была проделана нашими предшественниками по организации музеев и их деятельности. Главная заслуга в этом устроителя университета профессора В.М. Флоринского.

The article presents a brief overview of the history of the fund collections creation at Tomsk University, the main trends in the activities of the museums characteristic of that period from 1882 to 1917 have been revealed. In the process of developing a scientific project of the exhibition «The patrons and first collections of the Imperial Tomsk university museums» the author realized what huge work had been done by the predecessors in organizing museums and their activities. The main contribution of professor V.M. Florinsky made to that work has been noted.

Ключевые слова: музеи Томского университета, В.М. Флоринский, меценаты музея, археологические и этнографические коллекции, чучело, экспозиция.

Keywords: the museums of Tomsk University, V.M. Florinsky, museum patrons, archaeological and ethnographic collections, stuffed animal, exposition.

Деятельность людей, стоявших у «колыбели» музеев, а это устроитель Императорского Томского университета В.М. Флоринский и первые сотрудники, позволила запустить процесс формирования уникальных по своему количественному и качественному составу музейных собраний. Выводы, которые напрашиваются после изучения всего доступного нам материала, заставляют в очередной раз обратиться к вечной теме для размышлений о роли личности в истории. В.М. Флоринскому удалось собрать коллектив, совсем небольшой по численности, объединенный идеей просвещения Сибири. Главные качества, присущие пер- 
вым профессорам и их помощникам - профессионализм, высокая работоспособность, порядочность, а также желание работать на общее дело.

В 1878 г. император Александр II своим Указом учредил первый Сибирский университет в Томске. 22 июля 1888 г. состоялось торжество открытия Императорского Томского университета согласно Указу императора Александра III [7, с. 3]. В.М. Флоринский вошел в «большую» историю как устроитель первого за Уралом высшего учебного заведения. В 1880-1885 гг. он был членом Строительного комитета по возведению зданий Сибирского университета с особыми полномочиями от Министерства народного просвещения, в 1885-1891 гг. - председателем Комитета. В 1885-1898 гг. - попечитель Западно-Сибирского учебного округа. В 1898 г. был удостоен звания «Почетный гражданин города Томска» [16, с. 23$25 ; 18]$.

Василий Маркович занимался формированием библиотеки, закладкой ботанического сада, приобретением учебного оборудования, внес решающий вклад в комплектование фондового собрания всех университетских музеев. Музейная проблематика для него была не нова: еще во время службы в Казанском университете он увлекался изучением и собиранием древностей. По образованию он врач, в Казани пребывал в должности ординарного профессора Казанского университета по кафедре акушерства и гинекологии. Тем не менее, к своему увлечению историей относился очень серьезно, в 1879 г. он составил и защитил на собрании Общества археологии, истории и этнографии при Императорском Казанском университете Проект публичного историко-этнографического музея $[1$, с. 15], реализовать который ему довелось в Томске.

Благодаря его усилиям на момент открытия ИТУ в 1888 г. уже существовали Ботанический музей или Гербарий, Зоологический музей, Музей геологии, геогнозии и минералогии и Археологический музей, который оказался фактически вне Устава университета, потому что высочайшим решением ИТУ открылся в составе одного факультета - медицинского, а историко-филологический факультет, предполагавшийся ранее, был исключен. Музей по факту был, а финансирования и штатных сотрудников для него не было. Все обязанности по формированию коллекций и по работе с ними В.М. Флоринский возложил на себя. Вполне заслуженно в 2003 г. имя В.М. Флоринского было присвоено Музею археологии и этнографии ТГУ. Кроме него лишь с 1 сентября 1890 г. при музее появился особый служитель для черных работ [12, с. 25].

Основание музея было приурочено к 6 декабря 1882 г. - Дню празднования 300-летия присоединения Сибири к России: к этому дню был решен вопрос о пожертвовании музею первой археологической коллекции Тобольских древностей. Коллекция была собрана художником М. Знаменским вблизи Тобольска на Чувашском мысу и по просьбе В.М. Флоринского приобретена на деньги красноярского купца М.К. Сидорова за 300 руб. для дальнейшей передачи в университет [2, с. 255]. 
Все предметы, поступающие в музей, должны быть поставлены на учет и грамотно атрибутированы. Это начало процесса исследования, залог дальнейшей успешной работы с фондовым собранием. В музеях предполагалось создать прекрасные условия для исследовательской работы профессоров и талантливых студентов. Изучение фондового собрания - есть непременное условие раскрытия его потенциала. Нужно знать свои фонды и пропагандировать их среди коллег из других российских и зарубежных университетов, призывая их к сотрудничеству.

Флоринский в 1882-1888 гг. принял и описал около 4500 музейных предметов и подготовил каталог археологических и этнографических коллекций. В Археологическом отделе каталога с 1 по 49 стр. перечисляются предметы из коллекции Тобольских древностей. Приведем описание одного из предметов: под № 470 значится глиняная лошадка... «длиною с хвостом и головой 6 сант., толщиной (туловище) немного меньше мизинца. На месте ног... 4 дырочки в таком положении, что животное представлено скачущим, чему соответствует положение вытянутой шеи. ...фигурки, вылепленные с слабыми проблесками искусства, напоминают собою детские игрушки. Значение их, вероятно, было религиозное» [20, с. 16].

Музейные фонды поначалу формировались посредством покупки или дарения. Примером добровольного пожертвования университету является передача настоятелем Русской духовной миссии в Иерусалиме в 1869-1894 гг. Архимандритом о. Антонином (в миру - Капустин Андрей Иванович) 364 монет (серебряных и бронзовых) 93 разновидностей эпохи Древней Греции и Рима [11, с. 40]. Архимандрит о. Антонин - археограф, археолог, историк христианского Востока; на русском участке в Иерихоне он обнаружил остатки византийского храма VI века, его мозаичных полов. В результате раскопок на русском участке на Елеоне им были найдены два мозаичных пола, один из которых представляет собой уникальный образец мозаичного искусства и датируется V-VI веками. Находки, добытые в результате раскопок, обогащали не только специально созданный о. Антонином археологический музей Миссии в Иерусалиме, но и церковно-археологические собрания российских Духовных Академий $[8]$.

В разных музеях пополнение коллекций шло с разной степенью интенсивности. Так, в Зоологическом музее в 1893 г. служили Николай Феофанович Кащенко, профессор по кафедре зоологии и сравнительной анатомии, и Василий Петрович Аникин, консерватор [13, с. 1, 3]. Они занимались комплектованием фондов профессионально во время экспедиций и командировок. Хотя единичные поступления от любителей продолжались. Фонды музея серьезно пополнились благодаря командировке профессора Н.Ф. Кащенко в Москву, Петербург и страны Европы в 18921893 гг. Часть предметов была приобретена на «особо ассигнованную для этой цели сумму» из процентов на Сибиряковский капитал, например, чучело орангутана у г-на Керца в Штутгарте, Германия; множество 
препаратов и скелеты орангутана, страуса и морской свиньи куплены у известного чешского зоолога и палеонтолога г. Фрича в Праге. В Вене от фирмы «Lenoir and Forster» были закуплены скелеты павиана, летучей собаки, черепахи [13, с. 25].

Своими коллекциями с Томским университетом обменивались благодаря личным отношениям с Н.Ф. Кащенко - Императорская Академия Наук в Санкт-Петербурге, Императорское Общество Любителей Естествознания в Москве, Московский Комитет Шелководства, Зоологический Музей Варшавского университета, Зоологический Музей Харьковского университета, известный специалист по моллюскам доктор Бранчик из Венгрии, профессора из Киева Оболенский и Совинский. Надо отметить, что практически все препараты, полученные от коллег, «точно определены», т.е. атрибутированы [13, с. 26].

Николай Феофанович с помощью своей жены, которая сопровождала его в этой поездке, собрал коллекцию раковин наземных и пресноводных моллюсков в разных местностях Италии и Европейской России из 74 экз., а также коллекцию из 92 экз. морских раковин, «отчасти лично собранных в Италии в окрестностях Неаполя, Рима, Венеции, отчасти купленных там же в розницу на собственные средства» [13, с. 27].

Зоологический музей славится тем, что в экспозиции представлено множество чучел птиц. Пернатые «слетались» в музей со всех континентов и из разных регионов Российской империи. Если «иностранцы» поступали в музей единичными экземплярами, то птицы, обитающие на территории России, целыми стаями, сотнями и тысячами.

Особого внимания заслуживает коллекция, пожертвованная в 1885 г. степным генерал-губернатором Г.А. Колпаковским: 1805 шкурок среднеазиатских птиц и 33 шкурки млекопитающих. Эта коллекция представляет «богатый зоологический материал именно по многочисленности одного и того же вида из различных еще мало известных местностей, а также и потому, что она добыта в разные времена года... каждая в отдельности имеет точное обозначение места нахождения, пол и время добывания». Коллекция была оценена по каталогам иностранных фирм на сумму 1171 руб. 02 коп. [6, с. 35]. Эта первая по времени поступления коллекция была собрана в бытность Колпаковского военным губернатором Семиреченской области по его распоряжению в Семиреченской области и Кульджинской провинции (территория Китая). Впоследствии из части шкурок были изготовлены чучела, а остальные использовались в качестве обменного фонда.

В Томском областном архиве хранится черновик Благодарственного письма от 22 марта 1886 г. на имя Г.А. Колпаковского, написанное рукой В.М. Флоринского. Завершается оно фразой: «Имею честь покорнейше просить принять уверение в истинном почтении и совершенной преданности. Вашего Высокопревосходительства покорнейший слуга» [15, л. 60-60 об.]. 
Надо сказать, что всем дарителям в обязательном порядке отправлялись письма с благодарностями за подписью В.М. Флоринского.

Очень успешным для пополнения птичьих коллекций был 1914 г., год начала Первой мировой войны. По ходатайству заведующего Кабинетом профессора М.Д. Рузского Советом Императорского Томского Университета была ассигнована сумма из Сибиряковского капитала в количестве 2500 руб. (из них было расходовано 1354 руб. 80 коп.) для пополнения коллекций «новыми объектами (спиртовыми и набитыми) из представителей иноземных фаун, а равно и оптическими инструментами для Зоологического кабинета» [14, с. 10].

Всего в 1914 г. было приобретено 52 чучела, 50 спиртовых и прочих препаратов и 2 микроскопа. Из особо ценных приобретений - настоящая жемчужница с жемчужиной. Перечислим некоторые приобретения [14, с. 10-12]. Из Южной Америки в Томск прибыл попугай сине-желтый ара с красивым ярким опереньем, так не характерным для наших сибирских птиц. Другой попугай - Жако, или серый попугай - родом из Западной Африки, он гнездится в Анголе, Конго, Гвинее и пр. странах. В Западной же Африке гнездится Ибис Каравайка с большим загнутым книзу клювом. А нелетающая морская птица - очковый пингвин - родился на островах южной оконечности Африканского континента. Э́му - крупнейшая австралийская птица, он способен бежать со скоростью 50 км/ч. Длинные ноги позволяют делать шаги до 275 см. Выходцы из Европы также оказались в этой компании. Шотландская куропатка, из семейства тетеревиных, обитала в вересковых пустошах в Великобритании или Ирландии. Вместе с ней прибыл кавказский тетерев - крупная птица семейства фазановых. Краснохвостый фаэтон Ареа гнездится на островах Индийского и Тихого океана. Мы предполагаем, что наш фаэтон обитал на острове Пасхи. Этим птицам можно было встретиться лишь в музее.

В тот же год экспозицию Зоологического музея пополнили, кроме птиц, чучела невиданных животных [14, с. 10-12]. Начнем с «иноземцев», обитающих в Южной Америке. Енот-ракоед - вид енотов, происходящий из болот и джунглей Центральной и Южной Америки, как и гигантский муравьед - самый крупный представитель в отряде неполнозубых. Оттуда же родом и обыкновенная игуана, или зелёная игуана, крупная растительноядная ящерица. Африканский континент представляет Нильский варан, крупнейшей и один из самых распространённых ящериц в Африке. Из животных, обитающих в Юго-Восточной Азии, самой необычный экстерьер у панголина или яванского ящера. Несмотря на сходство с пресмыкающимися, относится к млекопитающим. Живет в лесах, активно лазает по деревьям в поисках пищи. С далекого от России Австралийского континента в холодную Сибирь попала теплолюбивая австралийская ехидна.

Всего к концу 1914 г. в музее было поставлено на учет 1049 чучел, других препаратов (сухих и спиртовых) - 3520 единиц и 39 моделей [14, c. 7]. В конце 1889 г., согласно Отчету, в музее было всего 147 чучел, 
иных препаратов (преимущественно спиртовых) - 391 и 5 моделей [11, с. 27]. За 25 лет фонды заметно увеличились.

Музей учебного заведения существенно отличается от музея публичного. В первую очередь, музеи создавались для обучения студентов. Занятия со студентами проходили (и сейчас проходят) в помещении музеев. «Практические занятия со студентами в 1889 г. состояли: 1) во вскрытии студентами, под руководством и под наблюдением преподавателя, главнейших представителей животного царства, 2) в изучении готовых зоологических препаратов и 3) в исследовании под микроскопом одноклеточных и других мелких животных...» [11, с. 30].

Для проведения лабораторных и практических занятий нужен учебный материал. Необходимость иметь несколько одинаковых бабочек, жуков или шкурок суслика объяснялась тем, что во время занятий студенты могут недостаточно бережно обращаться с учебными материалами и привести их в негодность. Предметы Зоологического музея очень непросты в обращении. Органика подвержена процессам гниения, усыхания, разложения. Это процессы естественные, их можно замедлить, но не отменить вовсе. Поэтому фонды музея должны пополняться новыми предметами постоянно; а те чучела и препараты, сохранность которых уже не позволяет их экспонировать, подлежат списанию. В музеях университета имелись т.н. дубликаты для учебных целей и для обмена с другими музеями.

Открытие университета не могло не всколыхнуть наш город, в последующие годы влияние университета на город только усиливалось. Университетские музеи с первых дней своего существования не были оторваны от социума. Демонстрация богатейших музейных собраний широкой публике - дело необходимое, самый простой путь установления положительных контактов с горожанами. Посещение экспозиции заставляет людей проникнуться пониманием значимости роли университета в деле просвещения и приобщения к культуре. Музейные экспонаты должны быть аттрактивны, интересны для любой публики: это тоже не могло не учитываться при комплектовании фондов. Хотя для специалиста-исследователя эти предметы могут быть недостаточно информативны.

Первая университетская научная выставка открылась 27 декабря 1888 г., работала всего 13 дней - вплоть до 8 января 1889 г. и получила большой общественный резонанс. Выручка, составившая 623 руб., была направлена в пользу Общества содействия начальному образованию. Выставку посетили 1820 человек, в их числе более 200 детей [5, с. 87]. А население Томска, согласно Городской переписи 1880 г., составляло немногим более 33 тыс. человек [4, с. 119]. Следовательно, выставку посетило более $5 \%$ горожан и гостей города - это очень много для того времени.

Судя по фотографиям, на выставке экспонировались коллекции минералов, череп и кости мамонта и других древних животных, чучела зверей и птиц. Но более всего публику привлекала «...богатейшая коллекция по сибирской археологии и этнографии и совершенно своеобраз- 
ная коллекция принадлежностей быта североамериканских индейцев» [10, с. 39]. Уникальные экспонаты, помещенные в т.н. «Американскую витрину», были собраны в 1876-1877 гг. во время путешествия по США Иннокентием Петровичем Кузнецовым-Красноярским и подарены музею. В каталоге перечислено 125 предметов и фотографий этой коллекции: одежда и головные уборы с перьями, мокасины и кисеты, луки, стрелы, колчаны, томагавки, трубка мира, портсигар, аркан из конского волоса, хвост буйвола и пр. А также панорамные снимки горных перевалов, фотографии речных портов, мостов, озер, виды Ниагарского водопада и фотопортреты представителей разных индейских племен [20, с. 97103]. Увиденные фотографии навели В.М. Флоринского на размышления о поразительном сходстве в облике индейцев Северной Америки и «наших финских инородцев» [21, с. 234].

Среди дарителей, говоря иначе - жертвователей - были люди всякие, из разных сословий, с разным достатком. Были среди них и такие персоны, без участия которых Томский университет мог не состояться.

В целом «на строительство и обустройство университетских зданий было истрачено всего 814 тыс. руб., при этом купеческие пожертвования превышали 310 тыс. руб.» [3, с. 95]. Иркутский купец и золотопромышленник Сибиряков Александр Михайлович в августе 1878 г. в письме Генерал-губернатору Западной Сибири Н.Г. Казнакову сообщал: «...я решил пожертвовать сто тысяч рублей серебром на Сибирский университет в Томске... Считаю не лишним прибавить, что пожертвование это сделано мною в память моего покойного отца» [9, с. 23]. Получается, что каждый восьмой рубль, потраченный на университет, был Сибиряковский. По решению жертвователя эти деньги и проценты с них необходимо было использовать на устройство и содержание учебно-вспомогательных учреждений, на учебные пособия [19, с.77]. На протяжении многих лет приобретения для музеев делались на эти средства.

Кроме денежных вложений Александр Михайлович неоднократно делал иные подарки университету. В 1882 г. по решению А.М. Сибирякова были переданы зоологическая и ботаническая коллекция сухих растений, собранные экспедицией шведского полярного исследователя Н.А.Э. Норденшельда по Северному морскому пути. А.М. Сибиряков взял на себя почти половину расходов на снаряжение экспедиции. «Коллекция беспозвоночных, пожертвованная Норденшельдом, собранная во время экспедиции «Вега», состоит из следующих видов: ракообразных 32 склянки, моллюсков 205 склянок, плеченогих 7, мшанок в спирту 8 и сухих 65, иглокожих в спирту 8 банок» [6, с. 35].

В 1884 г. А.М. Сибиряков через своего доверенного Ф.Г. Черепанова передал музею археологии и этнографии доспехи самурая, принадлежавшие знатному самурайскому роду и изготовленный не позднее XVII в. [9, с. 27]. 
В каталоге Археологического музея под № 2167 значится: «Японское рыцарское облачение (шлем, личина, панцирь и наколенники). Доставлен А.М. Сибиряковым. (На манекене)» [20, с. 128].

Минусинский купец, краевед, собиратель древностей Георгий Павлович Сафьянов [17] пожертвовал сойотскую этнографическую коллекцию, собранную в верховьях реки Енисей и состоящую из 70 предметов. Перечень предметов, расположенных в «Сойотской витрине» занимает 4 страницы в Каталоге. Первым по списку под № 2476 значится «Халат ламы (кижинемъ токте) из бумажной ткани желтого цвета с черной плисовой оторочкой по вороту и рукавам (новый)». И далее перечисляются предметы быта из дерева и кожи, посуда, барянья лопатка, употребляемая при гадании, ножи, каягю - помет мелкого млекопитающего, употребляемый сойотами как лекарство, музыкальные инструменты, трубки, орудия пытки для защемления пальцев, украшения, седла, лошадиная сбруя, мужская и женская одежда [20, с. 142-145].

В настоящее время в экспозиции Музея археологии и этнографии ТГУ им. В.М. Флоринского размещены экспонаты из более поздних поступлений: плащ-мантия ламы и головной убор, датируемые кон. XIX в. Приобретены вещи у представителей этнической общности - сойотов, проживавших на р. Онон, привезены из Забайкалья и переданы в МАЭС в 1929 г. И.В. Атласовым. В витринах экспонируются также привезенные из Центральной Азии предметы кон. XIX - начало XX вв.: медные колокольчики - хонхо, ритуальный буддийский барабан, маленькие ручные барабаны - дамару.

Подводя итоги всему сказанному, можно утверждать, что в своей речи на торжественном открытии Томского университета 22 июля 1888 г. В.М. Флоринский имел все основания заявить: «Относительно учебных и научных пособий Томский университет может считать себя особенно счастливым. Люди, близко принимающие к сердцу потребности высшего просвещения, помогли ему подготовить к открытию учебных курсов богатые коллекции по многим отраслям естествознания... Мне особенно приятно указать здесь на эти богатые приобретения, потому что все они составились из добровольных пожертвований частных лиц, и при том не одних сибиряков, но по преимуществу ревнителей просвещения из Европейской России» [22, с. 7].

Так получилось, что данная статья - это всего лишь краткий обзор, за рамками которого осталось невероятно много уникальных коллекций и единичных экземпляров, поступивших в фонды музеев ИТУ. Чего стоит, например, прекрасная коллекция Золенгофенских сланцев с отпечатками древнейших растений и живых организмов! Или легенды вокруг попадания предметов в коллекции - не всегда все было просто и гладко. А если рассказывать о дарителях, об их судьбах - конца этому не будет никогда.

Последние двадцать с лишним лет я проектирую и создаю экспозиции разных музеев. И всегда пытаюсь придумать, как можно показать 
какой-то исторический процесс или явление музейными средствами. Например, как показать в музейной экспозиции процесс комплектования музейных собраний? Пока еще не знаю. Но вот результат можно представить очень наглядно: надо взять огромный глобус, и флажками обозначать страны и регионы огромной Российской империи, откуда поступали предметы в фонды университетских музеев. Вот это и будет полная картина. Нет никаких сомнений в том, что на глобусе не останется свободного места.

\section{Примечания}

1.Дементьев А. Д. В. М. Флоринский: проект историко-этнографического музея // Мировое культурное наследие и музеи: история, проблемы и перспективы : материалы Всерос. науч.-практ. конф. с междунар. участием / отв. ред. И.А. Сизова. Томск : Изд-во Том. ун-та, 2017. С. 1216.

2.Дмитриев-Мамонов А. К. К истории первого университета в Сибири (1875-1899): памяти В.М. Флоринского // Императорский Томский университет в воспоминаниях современников / отв. ред. С.Ф. Фоминых. Томск : Изд-во Томск. ун-та, 2014. С. 230-266.

3.Дмитриенко Н. М. Императорский Томский университет и сибирское купечество: опыт взаимодействия // Вестник Томского государственного университета. 2016. № 413. С. 94-102.

4.Дмитриенко Н. М. Сибирский город Томск в XIX - первой трети $\mathrm{XX}$ века: управление, экономика, население. Томск : Изд-во Томск. ун-та, 2000. $284 \mathrm{c}$.

5.Дмитриенко Н. М., Черняк Э. И. Музеи Императорского Томского университета: первые годы создания и деятельности // Вестник Томского государственного университета. 2015. № 397. С. 81-90.

6.Известия Императорского Томского Университета : сведения о состоянии Императорского Томского университета за первое полугодие его существования. Кн. 1, отд. 1-2. Томск, 1889. URL: http://vital.lib.tsu.ru/vital/access/manager/Repository/vtls:000196204 (дата обращения: 27.05.2019).

7.Императорский Томский университет в воспоминаниях современников / отв. ред. С. Ф. Фоминых. Томск : Изд-во Томск. ун-та, 2014. $508 \mathrm{c}$.

8.Краткая история и деятельность Русской Духовной Миссии в Иерусалиме // Московский патриархат. Русская духовная миссия в Иерусалиме. URL: https://rusdm.ru/history/392. (дата обращения: 27.05.2019).

9.Майер Г. В., Фоминых С. Ф. Александр Михайлович Сибиряков и Томский университет // «Цели развития тысячелетия» и инновационные принципы устойчивого развития арктических регионов : междунар. конгресс. Т. 2. Наследие А. М. Сибирякова в укреплении евразийского сотрудничества и утверждении общечеловеческих ценностей : науч.практ. конф., Санкт-Петербург, 13-14 нояб. 2009 г. СПб., 2009. С. 22-30. 
10.Некрылов С. А., Фоминых С. Ф., Черняк Э. И. Начало формирования музейных и ботанических коллекций первого в Азиатской России Сибирского (Томского) университета (конец 1870-х - 1888 г.) // Томские музеи : сб. док. и статей. Томск : Изд-во Томск. ун-та, 2010. С. 3-40.

11.Отчет о состоянии Императорского Томского Университета за 1889 год. Томск : Типо-Литография В. В. Михайлова и П. И. Макушина, 1890. URL: http://vital.lib.tsu.ru/vital/access/manager/Repository/vtls: 000155710 (дата обращения: 27.05.2019).

12.Отчет о состоянии Императорского Томского университета за 1890 г. Томск : Типо-Литография В.В. Михайлова и П. И. Макушина, 1891. URL: http://vital.lib.tsu.ru/vital/access/manager/Repository/vtls: 000184732 (дата обращения: 27.05.2019).

13.Отчет о состоянии Императорского Томского университета за 1893 год. Томск, 1894. URL: http://vital.lib.tsu.ru/vital/access/manager/ Repository/vtls: 000198239. (дата обращения: 27.05.2019).

14.Отчет о состоянии Императорского Томского университета за 1914 год. Отдел 2. Томск, 1915. С. 1-37. URL: http://vital.lib.tsu.ru/vital/access/manager/Repository/vtls:000247607. (дата обращения: 24.05.2019).

15.ГАТО. (Государственный архив Томской области). Ф. 126. Оп. 1. Д. 61. Л. 60-60 об.

16.Ректоры Томского университета : биогр. словарь. Т. 5 / [С. Ф. Фоминых, С. А. Некрылов, К. В. Петров и др. ; гл. ред. С. Ф. Фоминых] ; Том. гос. ун-т. Томск : Изд-во Томск. ун-та, 2003. URL: http://vital.lib.tsu.ru/vital/access/manager/Repository/vtls:000174567. дата обращения: 27.05.2019).

17.Сафьянов Георгий Павлович // Библиотека сибирского краеведения. URL: http://bsk.nios.ru/enciklodediya/safyanov-georgiy-pavlovich. (дата обращения: 27.05.2019).

18.Флоринский Василий Маркович // Ректоры Томского университета : биогр. словарь (1888-2003) / С.Ф. Фоминых, С.А. Некрылов, К.В. Петров, А.В. Литвинов, К.В. Зленко. Томск : Изд-во Томск. ун-та, 2003. T. 5. C. 20-27.

19.Флоринский В. М. Заметки и воспоминания. 1875-1880 // Императорский Томский университет в воспоминаниях современников / отв. ред. С.Ф. Фоминых. Томск : Изд-во Томск. ун-та, 2014.

20.[Флоринский В. М.] Музей Сибирской археологии и этнографии, основанный в 1882 г. при Сибирском университете // Археологический музей Томского университета : [каталог]. Томск, 1888. Пагинация 3. C.1-155. URL: http://vital.lib.tsu.ru/vital/access/manager/Repository/vtls: 000194128 (дата обращения: 27.05.2019).

21.[Флоринский В. М.] Примечания к описанию археологического музея Сибирского университета // Археологический музей Томского университета : [каталог]. Томск, 1888. Пагинация 4. С. 1-275. URL: 
http:/vital.lib.tsu.ru/vital/access/manager/Repository/vtls:000194128. (дата обращения: 27.05.2019).

22.Флоринский В. М. Речь по поводу открытия Императорского Томского университета, произнесенная 22 июля 1888 г. // Первый университет в Сибири. Томск : Тип. Сибир. вестника, 1889. С. 2 - 8. URL: https://elib.tomsk.ru/purl/1-8089/. (дата обращения: 27.05.2019) .

\section{References}

1. Dementyev A. D. V.M. Florinskij: proekt istorikoetnograficheskogo muzeja [Florinskiy V.M.: project of the historicalethnographic museum] // Mirovoje kul'turnoje nasledie i muzei: istorija, problemy i perspektivy: materialy Vserossijskoj nauchno-prakticheskoj konferencii s mezhdunarodnym uchastiem [World cultural heritage and museums: history, problems and prospects: materials of the All-Russian scientific-practical conference with international participation]. Tomsk, 2017. Pp. 12-16. [In Russ.].

2. Dmitriev-Mamonov A.K. K istorii pervogo universiteta v Sibiri (1875-1899): pamyati V.M. Florinskogo [To the history of the first university in Siberia (1875-1899): in memory of V.M. Florinsky] // Imperatorskij Tomskij universitet $\mathrm{v}$ vospominaniyakh sovremennikov [The Imperial Tomsk University in the contemporaries' memoirs] / chief ed. S.F. Fominykh. Tomsk, 2014. Pp. 230-266. [In Russ.].

3.Dmitrienko N.M. Imperatorskiy tomskiy universitet i sibirskoe kupechestvo: opyt vzaimodejstvija [Imperial Tomsk University and Siberian merchants: the experience of co-operation] // Vestnik Tomskogo gosudarstvennogo universiteta [Tomsk State University Bulettin]. 2016. № 413. Pp. 94-102. [In Russ.].

4.Dmitrienko N. M. Sibirskij gorod Tomsk v XIX - pervoj treti XX veka: upravlenije, ekonomika, naselenije [Siberian city of Tomsk in the XIX ${ }^{\text {th }}$ - first third of the $\mathrm{XX}^{\text {th }}$ century: management, economy, population]. Tomsk, 2000. 284 p. [In Russ.].

5.Dmitrienko N.M., Chernyak, E.I. Muzei Imperatorskogo Tomskogo universiteta: pervyje gody sozdanija i dejatel'nosti [Imperial Tomsk University Museums: the first years of establishment and activities] // Vestnik Tomskogo gosudarstvennogo universiteta [Tomsk State University Bulettin].2015. № 397. Pp. 81-90. [In Russ.].

6.Izvestija Imperatorskogo Tomskogo universiteta : svedenija o sostojanii Imperatorskogo Tomskogo universiteta za pervoe polugodije ego sushchestvovanija [The news of the Imperial Tomsk University: information about the state of the Imperial Tomsk University in the first half of its existence]. Book 1 (1-2). Tomsk, $1889 . \quad$ URL: http://vital.lib.tsu.ru/vital/access/manager/Repository/vtls:000196204 (27.05.2019). [In Russ.]. 
7. Imperatorskij Tomskij universitet $\mathrm{v}$ vospominaniyakh sovremennikov [The imperial Tomsk University in the contemporaries' memoirs]. Tomsk, 2014. 508 p. [In Russ.].

8. Kratkaja istorija i dejatel'nost' Russkoj Dukhovnoj Missii v Ijerusalime [Brief history and activities of the Russian Ecclesiastical Mission in Jerusalem] // Moskovskij patriarkhat : Russkaja dukhovnaja missija v Ierusalime [Moscow Patriarchate: The Russian Ecclesiastical Mission in Jerusalem]. URL: https://rusdm.ru/history/392 (27.05.2019). [In Russ.].

9.Mayer G.V., Fominykh, S.F. Aleksandr Mikhajlovich Sibirjakov i Tomskij universitet [A.M. Sibiryakov and Tomsk University] // "Tseli razvitija tysjacheletija" i innovatsionnye printsipy ustojchivogo razvitija arkticheskikh regionov. Materialy mezhdunarodnogo kongressa ["Millennium Development Goals" and innovative principles of the Arctic Regions sustainable development]. Vol. 2. S.-P., 2009. Pp. 22-30. [In Russ.].

10. Nekrylov S.A., Fominykh S.F., Chernyak E.I. Nachalo formirovanija muzejnykh i botanicheskikh kollekcij pervogo $\mathrm{v}$ Aziatskoj Rossii Sibirskogo (Tomskogo) universiteta (konec 1870-kh - 1888 g.) [The formation of museums and botanical collections in the Siberian (Tomsk) university, first in Asiatic Russia (the end of the 1870s - 1888)]. Tomskije muzei : sb. dokumentov i statej [Tomsk Museums: book of documents and articles]. Tomsk, 2010, Pp. 3-40. [In Russ.].

11.Otchet o sostojanii Imperatorskogo Tomskogo universiteta za 1889 god [Report on the Imperial Tomsk University condition in 1889]. Tomsk. URL: http://vital.lib.tsu.ru/vital/access/manager/Repository/vtls:000155710 (27.05.2019). [In Russ.].

12. Otchet o sostojanii Imperatorskogo Tomskogo universiteta za 1890 god [Report on the Imperial Tomsk University condition in 1890]. Tomsk. URL: http://vital.lib.tsu.ru/vital/access/manager/Repository/vtls:000184732 (27.05.2019). [In Russ.].

13. Otchet o sostojanii Imperatorskogo Tomskogo universiteta za 1893 god [Report on the Imperial Tomsk University condition in 1893]. Tomsk. URL: http://vital.lib.tsu.ru/vital/access/manager/Repository/vtls:000198239 (27.05.2019). [In Russ.].

14.Otchet o sostojanii Imperatorskogo Tomskogo universiteta za 1914 god [Report on the Imperial Tomsk University condition in 1914]. Tomsk. 1915. (II). pp. 1-37. URL: http://vital.lib.tsu.ru/vital/access/manager /Repository/vtls:000247607 (24.05.2019). [In Russ.].

15. GATO [The state archive of the Tomsk Region). Fund 126. Inv 1. C. 61. L.60-60 ob.

16.Rektory Tomskogo universiteta : biograficheskij slovar' [Rectors of Tomsk University: biographical dictionary]. V. 5 / [S.F. Fominykh, S.A. Nekrylov, K.V. Petrov [et al]; chief ed. S.F. Fominykh]. Tomsk,. 2003. URL: http://vital.lib.tsu.ru/vital/access/manager/

Repository/vtls:000174567

(27.05.2019). 
17. Safyanov Georgij Pavlovich. Biblioteka sibirskogo krajevedenija. [Library of the Siberian Local History]. URL: http://bsk.nios.ru/enciklodediya/ safyanov-georgiy-pavlovich (27.05.2019). [In Russ.].

18.Florinskij Vasilij Markovich. Rektory Tomskogo universiteta: Biograficheskij slovar' [Rectors of Tomsk University: biographical dictionary]. (1888-2003). Vol. 5. Tomsk, 2003. Pp. 20-27. [In Russ.].

19.Florinsky V. M. Zametki i vospominanija [Notes and memories]. 1875-1880 // Imperatorskij Tomskij universitet $\mathrm{V}$ vospominaniyakh sovremennikov [Imperial Tomsk University in the contemporaries' memoirs]. Tomsk, 2014. [In Russ.].

20.[Florinsky V. M.] Muzej Sibirskoj arkheologii i etnografii, osnovannyj v 1882 godu pri Sibirskom universitete [The Museum of the Siberian Archaeology and Ethnography founded in 1882 in the Siberian University] // Arkheologicheskij muzej Tomskogo universiteta [The archaeological museum of Tomsk University]. Tomsk. Pp.1-155. URL: http://vital.lib.tsu.ru/vital/access/manager/Repository/vtls:000194128 (27.05.2019). [In Russ.].

21.[Florinskij V. M.] Primechanija k opisaniju arkheologicheskogo muzeja Sibirskogo universiteta [The notes to the description of the Archaeological Museum of the Siberian University] // Arkheologicheskij muzej Tomskogo universiteta [The archaeological museum of Tomsk University]. Tomsk, 1988. http://vital.lib.tsu.ru/vital/access/manager/ (27.05.2019). [In Russ.].

22.Florinsky V. M. Rech po povodu otkrytija Imperatorskogo Tomskogo universiteta, proiznesennaja 22 ijulja $1888 \mathrm{~g}$. [Speech at the opening of the Imperial Tomsk University delivered on July 22, 1888]. // Pervyj universitet $\mathrm{v}$ Sibiri [The first University in Siberia]. Pp. 2-8. URL: https://elib.tomsk.ru/purl/1-8089/ (27.05.2019). [In Russ.]. 
DOI 10.31443/2541-8874-2019-2-10-38-46

УДК 581.543(571.54)

Санданов Д.В., Батоцыренов Э.А.

Sandanov D. V., Batotsyrenov E.A.

\section{ОСОБЕННОСТИ ВЕСЕННЕГО ЦВЕТЕНИЯ РАСТЕНИЙ БУРЯТИИ: АНАЛИЗ АРХИВНЫХ ФЕНОЛОГИЧЕСКИХ МАТЕРИАЛОВ FEATURES OF SPRING PLANT BLOOMING IN BURYATIA: ANALYSIS OF THE ARCHIVAL PHENOLOGICAL MATERIALS}

Приведен обзор архивных фенологических материалов, характеризующих весеннее цветение растений Бурятии. Рассмотрены типы весен, порядок зацветания весенних растений и динамика их цветения в различных районах Бурятии.

A review of the archival phenological materials characterizing spring plant blooming in Buryatia has been presented. The types of spring, order of spring plants blooming and its blooming dynamics in different districts of Buryatia are considered.

Ключевые слова: фенология растений, архивные данные.

Keywords: plant phenology, archival data.

Пора пробуждения природы после зимних холодов всегда остается интересным явлением, которое привлекает как научных исследователей, так и любителей-натуралистов. Фенологические наблюдения, особенно за ростом и ритмом весеннего развития растений, издавна хорошо фиксировались и отображались в различных отчетах, записях, полевых дневниках, фенологических бланках и т.д. Часть этого объемного материала введена в научный оборот, а другая еще ждет своих исследователей. В фондах Государственного архива Республики Бурятия и Кяхтинского краеведческого музея имени академика В.А. Обручева хранятся многочисленные фенологические материалы Иннокентия Сергеевича Котова - известного краеведа Забайкалья, руководителя фенологической комиссии Географического общества. Подробная информация о биографии И.С. Котова и проведенных им фенологических исследованиях была опубликована нами ранее [1, с. 261-265; 2, с. 123-131].

Иннокентий Сергеевич был идейным вдохновителем и хорошим организатором изучения фенологии на территории Бурятии. К сожалению, ему не удалось при жизни опубликовать данные и результаты своих долговременных фенологических наблюдений. Фенолог вел наблюдения в Троицкосавске (Кяхте) с 1923 г., а в Верхнеудинске (Улан-Удэ) с 1930 г. до самой смерти (1969 г.). Из известных публикаций И.С. Котова можно упомянуть первый раздел «Общие физико-географические условия» в книге «Агроклиматический справочник по Бурятской АССР» (1960), бро- 
шюру «Сезонные явления в природе Бурятии» $(1968,2$ издание) и публикации в местных газетах под рубрикой «Заметки фенолога» (всего более 230 кратких сообщений). В данной статье мы упомянем ряд других публикаций исследователя, в которых отражены особенности цветения весенних растений Бурятии.

\section{Материал и методы исследования}

Обработка и анализ архивных фенологических данных проводились на основе фондов Государственного архива Республики Бурятия и Кяхтинского краеведческого музея имени академика В.А. Обручева в период с 2014 по 2019 гг. Предварительный анализ имеющихся материалов выявил их большую научную ценность, которая заключается в сборе материала по единой методике (специально разработанные фенологические бланки с учетом региональных особенностей) с охватом различных районов Бурятии и наличии постоянных наблюдений за цветением весенних растений.

Проанализирован большой массив данных, включая записи и фенонаблюдения И.С. Котова и многочисленных фенокорреспондентов со всех районов Бурятии. Все имеющиеся данные объединялись в сводные таблицы. Особое внимание уделялось рядам долговременных фенологических наблюдений в окрестностях г. Улан-Удэ, которые охватывают 40летний интервал (с 1930 по 1969 гг.). Фенологические даты были трансформированы в дни года, полученные данные использовались в статистическом анализе. Сравнительный статистический анализ этих наблюдений с метеоданными проводился с использованием программы StatSoftStatistica V. 10.0 [3]. Массивы метеоданных были загружены с сайта http://meteo.ru/data/162-temperature-precipitation\# [4].

\section{Результаты и их обсуждение}

Весеннее развитие растительности на территории Бурятии начинается цветением прострела раскрытого Pulsatilla patens. Первый период весны часто называют «неодетая весна». К этому времени сходит снежный покров, почва оттаивает на глубину пахотного слоя, начинают набухать почки у многих деревьев и кустарников. Второй период весны («одетая весна») в Бурятии начинается с цветением рододендрона даурского и длится до начала зацветания черемухи обыкновенной и яблони ягодной. Окончанием весны считается конец цветения яблони ягодной и накопление суммы эффективных температур в $300^{\circ}$. Примерно в эти сроки происходит устойчивый переход среднесуточной температуры воздуха через $+15^{\circ} \mathrm{C}$ [5, с. 41]. Л.И. Малышев [6, с. 14] отмечает, что у ранневесенних растений Прибайкалья наблюдается гораздо большее запаздывание сроков цветения в сравнении с западными территориями, чем у поздневесенних растений. Это связано с более холодными и затяжными веснами в изучаемом регионе. Фенологические наблюдения с 1930 по 1964 гг. позволили И.С. Котову выделить различные типы весен в Бурятии: очень ранние, ранние, нормальные, поздние и очень поздние (табл. 1). Классификация основана на сроках наступления и продолжительности трех ос- 
новных весенних периодов. Автор отмечает, что большинство весен в Улан-Удэ и его окрестностях относятся к типу поздних и составляет $34 \%$ от общего числа, а вместе с очень поздними - $45 \%$ [5, с. 42], т.е. почти в половине случаев весны в Улан-Удэ в среднем начинаются 26-30 апреля и их продолжительность составляет 48-50 дней.

Таблица 1

Классификация весеннего периода в окрестностях г. Улан-Удэ (данные за 1930-1964 гг.) [7, Л. 11]

\begin{tabular}{|c|c|c|c|c|c|c|c|c|}
\hline Типы весен & $\begin{array}{c}\text { Очень ко- } \\
\text { роткие } \\
42-52\end{array}$ & $\begin{array}{c}\text { Короткие } \\
45-55\end{array}$ & $\begin{array}{c}\text { Средние (нор- } \\
\text { мальные) } \\
51-62\end{array}$ & $\begin{array}{c}\text { Затяжные } \\
56-62\end{array}$ & $\begin{array}{c}\text { Очень за- } \\
\text { тяжные } \\
68-70\end{array}$ & $\begin{array}{c}\text { Средняя } \\
\text { продол- } \\
\text { житель- } \\
\text { ность, } \\
\text { дни }\end{array}$ & $\begin{array}{c}\text { Кол- } \\
\text { во }\end{array}$ & $\%$ \\
\hline $\begin{array}{l}\text { Очень ранние } \\
\text { (начало 6-10.IV) }\end{array}$ & & & & & 1938,1940 & 69 & 2 & 6 \\
\hline $\begin{array}{l}\text { Ранние } \\
\text { (начало 2-17.IV) }\end{array}$ & & & & $\begin{array}{l}1939,1945, \\
1947,1948 \\
1949,1957 \\
1959,1961 \\
\end{array}$ & & 60 & 8 & 23 \\
\hline $\begin{array}{l}\text { Средние } \\
\text { (начало 18-23.IV) }\end{array}$ & & & $\begin{array}{l}1932,1933,1935, \\
1943,1944,1953, \\
1958,1960,1962\end{array}$ & & & 54 & 9 & 26 \\
\hline $\begin{array}{l}\text { Поздние } \\
\text { (начало 24-29.IV) }\end{array}$ & & $\begin{array}{l}1930,1934, \\
1937,1941, \\
1942,1946, \\
1950,1951, \\
1952,1965 \\
1963,1964\end{array}$ & & & & 50 & 12 & 34 \\
\hline $\begin{array}{l}\text { Очень поздние } \\
\text { (начало 30.IV-5.V) }\end{array}$ & \begin{tabular}{|l|}
1931,1936, \\
1954,1956
\end{tabular} & & & & & 48 & 4 & 11 \\
\hline
\end{tabular}

При этом отмечается, что годы, когда наблюдалось раннее наступление весны и благоприятное обеспечение осадками, были урожайными. В целом, весны в Бурятии засушливые, дожди выпадают только в третьей декаде июня, что не всегда обеспечивает нормальный рост и развитие растений.

Самое раннее зацветание прострела раскрытого начинается на юге Бурятии. Среднемноголетние данные цветения прострела по Кяхте составляют17 апреля, с колебаниями от 3 апреля в 1938 году, до 2 мая в 1936 году. В окрестностях Улан-Удэ цветение прострела в среднем начинается 22 апреля. Самые поздние среднемноголетние даты начала цветения вида отмечены в Кабанске (2 мая) и на станции Мысовой (9 мая). Это, несомненно, связано с влиянием Байкала и с более высоким снежным покровом, который сходит весной гораздо позже. На восточном побережье Байкала цветение прострела также начинается позже, даты для Баргузина составляют 31 апреля, Горячинска - 10 мая. В этот же период начинается цветение этого растения в Еравнинском и Закаменском районах [8, л. 51]. 
Прострел раскрытый зацветает до развития листьев, т.е. до начала ассимиляции, развертывание листьев происходит в течение 5-7 дней после начала зацветания. Цветение на более освещенных и прогреваемых участках (опушки леса, южные склоны) начинается на несколько дней раньше, чем на теневых участках. Сроки наступления и прохождения фенофаз растений в основном зависят от температуры воздуха и почв. Например, начало вегетации прострела раскрытого связано с переходом среднесуточных температур воздуха через $0^{\circ} \mathrm{C}$. Наблюдения также показывают, что у листопадных древесных видов заметное набухание почек происходит при переходе среднесуточной температуры воздуха через $5^{\circ} \mathrm{C}$.

Температурные условия обусловливают и порядок зацветания растений. Так, в среднем по Бурятии тополь душистый зацветает после прострела раскрытого на 21 день, рододендрон даурский - на 22 день, береза повислая - на 28 день, черемуха обыкновенная - на 30 день, яблоня ягодная - на 40 день (табл. 2).

Таблица 2

Порядок зацветания растений весной в окрестностях Улан-Удэ

\begin{tabular}{|c|c|c|}
\hline $\begin{array}{c}\text { Название вида на латин- } \\
\text { ском }\end{array}$ & $\begin{array}{l}\text { Название вида на рус- } \\
\text { ском }\end{array}$ & $\begin{array}{c}\text { Среднемного-летние } \\
\text { значения }\end{array}$ \\
\hline Pulsatilla patens (L.) Mill. & Прострел раскрытый & 22.IV \\
\hline $\begin{array}{l}\text { Alyssum obovatum (C.A. } \\
\text { Meyer) Turcz. }\end{array}$ & $\begin{array}{l}\text { Бурачок обратнояйце- } \\
\text { видный }\end{array}$ & 26.IV \\
\hline Thlaspi cochleariforme DC. & Ярутка ложечная & 28.IV \\
\hline Potentilla acaulis $\mathrm{L}$. & Лапчатка бесстебельная & 30.IV \\
\hline Draba nemorosa L. & Драба перелесковая & 30.IV \\
\hline $\begin{array}{l}\text { Gagea pauciflora (Turcz. ex } \\
\text { Trautv.) Ledeb. }\end{array}$ & $\begin{array}{l}\text { Гусинолук малоцветко- } \\
\text { вый }\end{array}$ & $1 . \mathrm{V}$ \\
\hline Ulmus pumila $\mathrm{L}$. & Ильм приземистый & $3 . \mathrm{V}$ \\
\hline $\begin{array}{l}\text { Carex duriuscula C.A. } \\
\text { Meyer }\end{array}$ & Осока твердоватая & $10 . \mathrm{V}$ \\
\hline $\begin{array}{l}\text { Eritrichium sericeum } \\
\text { (Lehm) DC. }\end{array}$ & $\begin{array}{l}\text { Незабудочник шелко- } \\
\text { вистый }\end{array}$ & $11 . \mathrm{V}$ \\
\hline $\begin{array}{l}\text { Androsace lactiflora Fischer } \\
\text { ex Duby }\end{array}$ & $\begin{array}{l}\text { Проломник молочно- } \\
\text { цветковый }\end{array}$ & $12 . \mathrm{V}$ \\
\hline Populus tremula $\mathrm{L}$. & Тополь дрожащий & $13 . \mathrm{V}$ \\
\hline Populus suaveolens Fischer & Тополь душистый & $14 . \mathrm{V}$ \\
\hline Rhododendron dauricum L. & Рододендрон даурский & $15 . \mathrm{V}$ \\
\hline Betula pendula Roth. & Береза повислая & $19 . \mathrm{V}$ \\
\hline Iris humilis Georgi & Ирис низкий & $24 . \mathrm{V}$ \\
\hline Padus avium Miller & Черемуха обыкновенная & $27 . \mathrm{V}$ \\
\hline Malus baccata(L.) Borkh. & Яблоня ягодная & $31 . \mathrm{V}$ \\
\hline
\end{tabular}


Наблюдаются колебания интервалов по отдельным географическим пунктам. В качестве примера можно привести архивные данные по весне 1965 года (табл. 3).

Исследованиями И.С. Котова были рассчитаны суммы эффективных температур, при которых весной происходит зацветание растений: прострел раскрытый $-36,5^{\circ}$, тополь душистый - $48^{\circ}$, рододендрон даурский $-55^{\circ}$, береза повислая $-78^{\circ}$, черемуха обыкновенная- $114^{\circ}$, яблоня ягодная $156^{\circ}$, карагана древовидная $-175^{\circ}[10$, л. 56]. Корреляционный анализ дат зацветания прострела раскрытого в окрестностях г. Улан-Удэ (с 1930 по 1969 гг.) с метеоданными выявил, что для цветения вида значимое значение имеет температура воздуха в апреле (коэффициент корреляции $-0,75205$, т.е. при высоких температурах воздуха в апреле цветение вида начинается в более ранние даты). Значение коэффициента корреляции для средних температур марта и апреля также было довольно высоким $-0,70855$. При этом параметры осадков не имеют достоверной корреляции с датами цветения растения.

Таблица 3

Фенология дикорастущих деревьев и кустарников в различных населенных пунктах Бурятии в 1965 году

\begin{tabular}{|c|c|c|c|c|}
\hline $\begin{array}{c}\text { Населенный } \\
\text { пункт }\end{array}$ & $\begin{array}{c}\text { Вид расте- } \\
\text { ний }\end{array}$ & $\begin{array}{c}\text { Начало сокодви- } \\
\text { жения } \\
\end{array}$ & $\begin{array}{c}\text { Развертывание ли- } \\
\text { стьев }\end{array}$ & $\begin{array}{l}\text { Цвете- } \\
\text { ние }\end{array}$ \\
\hline \multirow[b]{2}{*}{ Гунда } & Береза & $18 . \mathrm{V}$ & $31 . \mathrm{V}$ & 04.VI \\
\hline & $\begin{array}{l}\text { Лиственни- } \\
\text { ца }\end{array}$ & - & $18 . \mathrm{V}$ & - \\
\hline \multirow{2}{*}{$\begin{array}{l}\text { Сосново-Озер- } \\
\text { ское }\end{array}$} & $\begin{array}{l}\text { Береза (ер- } \\
\text { ник) }\end{array}$ & $20 . \mathrm{V}$ & $28 . \mathrm{V}$ & $28 . \mathrm{V}$ \\
\hline & $\begin{array}{l}\text { Лиственни- } \\
\text { ца }\end{array}$ & - & $24 . \mathrm{V}$ & - \\
\hline \multirow{3}{*}{ Баргузин } & Береза & $04 . \mathrm{V}$ & $20 . \mathrm{V}$ & $26 . \mathrm{V}$ \\
\hline & $\begin{array}{l}\text { Рододенд- } \\
\text { рон }\end{array}$ & - & $22 . \mathrm{V}$ & 22. V \\
\hline & Черемуха & - & $18 . \mathrm{V}$ & 04.VI \\
\hline \multirow{3}{*}{ Кабанск } & Тополь & - & $26 . \mathrm{V}$ & $22 . \mathrm{V}$ \\
\hline & Береза & $05 . \mathrm{V}$ & $26 . \mathrm{V}$ & - \\
\hline & Черемуха & - & $20 . \mathrm{V}$ & $28 . \mathrm{V}$ \\
\hline Нестерово & Береза & $08 . \mathrm{V}$ & $26 . \mathrm{V}$ & $31 . \mathrm{V}$ \\
\hline \multirow[b]{2}{*}{ Цакир } & Береза & - & $24 . \mathrm{V}$ & $04 . \mathrm{VI}$ \\
\hline & $\begin{array}{l}\text { Лиственни- } \\
\text { ца }\end{array}$ & - & $18 . \mathrm{V}$ & $31 . \mathrm{V}$ \\
\hline \multirow{4}{*}{ Ташир } & Шиповник & - & $20 . \mathrm{V}$ & 12.VI \\
\hline & $\begin{array}{l}\text { Лиственни- } \\
\text { ца }\end{array}$ & - & $12 . \mathrm{V}$ & $20 . \mathrm{V}$ \\
\hline & Береза & 30.IV & $20 . \mathrm{V}$ & $26 . \mathrm{V}$ \\
\hline & Черемуха & - & $20 . \mathrm{V}$ & $31 . \mathrm{V}$ \\
\hline
\end{tabular}




\begin{tabular}{|l|l|c|c|c|}
\hline & Облепиха & - & $24 . \mathrm{V}$ & $08 . \mathrm{VI}$ \\
\hline Кяхта & $\begin{array}{l}\text { Рододенд- } \\
\text { рон }\end{array}$ & - & - & $20 . \mathrm{V}$ \\
\hline Бичура & Черемуха & - & $12 . \mathrm{V}$ & $22 . \mathrm{V}$ \\
\hline
\end{tabular}

Самое обильное цветение растений отмечается в мае, по наблюдениям в этот месяц в Бурятии цветет 160-180 видов растений [11, с. 127]. Вначале мая сосновые леса становятся ярко-зелеными, набухают почки на березе, яблоне, черемухе; в долинах рек цветут ивы. Вначале мая зацветает много степных растений, а в середине мая начинается цветение рододедрона даурского. Самая ранняя дата зацветания рододендрона даурского отмечена 3 мая в 1939 и 1943 гг. Самая поздняя дата 29 мая относится к особенно поздней весне 1931 г. Таким образом, размах колебаний начала цветения рододендрона даурского равняется 26 дням. Массовое цветение вида происходит в третью декаду мая, а в период холодной и поздней весны - в первую декаду июня. На юге Бурятии (окрестности г. Кяхта) средняя дата зацветания растения наблюдается 10 мая, в Кабанске и Баргузине -21 и 22 мая (табл. 4), в Горячинске и в Сосново-Озерском на южной окраине Витимского плоскогорья -4 июня [12, с. 115].

Таблица 4

Цветение растений в различных районах Бурятии по среднемноголетним данным

\begin{tabular}{|l|c|c|c|}
\hline \multicolumn{1}{|c|}{ Вид растения } & Кяхта & Кабанск & Баргузин \\
\hline Прострел раскрытый & $17 . \mathrm{IV}$ & $2 . \mathrm{V}$ & $1 . \mathrm{V}$ \\
\hline Лапчатка бесстебельная & $17 . \mathrm{IV}$ & - & \\
\hline Ярутка полевая & $21 . \mathrm{IV}$ & - & \\
\hline Осока твердоватая & $4 . \mathrm{V}$ & - & \\
\hline Тополь душистый & $8 . \mathrm{V}$ & - & - \\
\hline Незабудочник шелковистый & $10 . \mathrm{V}$ & - & \\
\hline Рододендрон даурский & $8 . \mathrm{V}$ & $21 . \mathrm{V}$ & $22 . \mathrm{V}$ \\
\hline Береза повислая & $14 . \mathrm{V}$ & $31 . \mathrm{V}$ & $30 . \mathrm{V}$ \\
\hline Черемуха обыкновенная & $21 . \mathrm{V}$ & $4 . \mathrm{VI}$ & $5 . \mathrm{VI}$ \\
\hline Яблоня ягодная & $27 . \mathrm{V}$ & $8 . \mathrm{VI}$ & $7 . \mathrm{VI}$ \\
\hline Купальница азиатская & $1 . \mathrm{VI}$ & $2 . \mathrm{VI}$ & \\
\hline Рябина сибирская & - & $7 . \mathrm{VI}$ & - \\
\hline Карагана древовидная & $1 . \mathrm{VI}$ & $9 . \mathrm{VI}$ & $10 . \mathrm{VI}$ \\
\hline Шиповник иглистый & - & $21 . \mathrm{VI}$ & - \\
\hline
\end{tabular}

Примечание: Таблица составлена на основе данных И.С. Котова $[13$, л. 12$]$ с дополнениями и уточнениями $[14$, с. $78-79$.

Корреляционный анализ дат зацветания рододендрона даурского в окрестностях г. Улан-Удэ с метеоданными не выявил особо значимых показателей температуры и осадков. Относительно значимыми для начала цветения вида являются температура воздуха в мае (коэффициент корреляции -0,49004). Значение коэффициента корреляции для средних температур апреля и мая было на сходном уровне $-0,4593$. Это свидетельствует 
о том, что для поздневесенних видов погодные условия определенных весенних месяцев не имеют особого значения. В большей степени начало цветения этих видов связано с накоплением определенной суммы эффективных температур.

В конце второй и начале третьей декады мая в долинах рек, поостровам цветет черемуха обыкновенная, а встепных районах по теплым каменистым склонам гор - миндаль черешчатый и абрикос сибирский. В последних числах мая вюжных и центральных районахначинается цветение яблони ягодной. Цветение этого вида является сигналом окончания весенних заморозков и начала лета $[11$, с. 127].

\section{Заключение}

Архивные фенологические данные являются хорошей основой для оценки адаптации растений к условиям среды и способствуют организации дальнейших исследований. Необходимо введение этих данных в научный оборот для возможности проведения их анализа с помощью современных методов. Имеющие архивные фенологические материалы позволили выявить особенности сезонного развития весенних растений Бурятии: динамику их цветения в различные годы и разных географических пунктах, порядок зацветания растений в окрестностях г. Улан-Удэ и связь начала цветения с параметрами температуры воздуха. В дальнейшем необходимо проведение современных фенологических наблюдений для оценки влияния изменений климата на сроки зацветания весенних растений Бурятии.

\section{Благодарности}

Авторы благодарны сотрудникам Государственного архива Республики Бурятия и Кяхтинского краеведческого музея имени академика В.А. Обручева за помощь в работе с архивными материалами. Исследования поддержаны грантом РГО №23/2019-Н5.

\section{Примечания}

1. Батоцыренов Э.А., Санданов Д.В. История фенологических исследований в Бурятии // Современные тенденции пространственного развития и приоритеты общественной географии: Мат-лы межд. науч. конф. (г. Барнаул, 12-19 сентября 2018 г.). - Барнаул, 2018а. - Т. 1. - С. 261-265.

2. Батоцыренов Э.А., Санданов Д.В. Вклад И.С. Котова в фенологические исследования в Бурятии // Архивы в истории. История в архивах: Сб. научн. статей / науч. ред. Б.Ц. Жалсанова. - Иркутск: Изд-во «Оттиск», 2018б. - С. 123-131.

3. Statistica: data analysis software system, version 10.0. StatSoft Inc., 2011. [Электронный ресурc]. URL: http://www.statsoft.com/ (дата обращения: 19.04.2019).

4. Булыгина О.Н., Разуваев В.Н., Александрова Т.М. Описание массива данных суточной температуры воздуха и количества осадков на метеорологических станциях России и бывшего CCCP(TTTR). 
Свидетельство о государственной регистрации базы данных № 2014620942.

5. Котов И.С. Типы весен города Улан-Удэ и его окрестностей и календарь цветения некоторых видов растений // Географические походы (вопросы организации массового туристского и краеведческого движения): Мат-лы III науч. совещ. географов Сибири и Дальнего Востока. Иркутск, 1966. - Вып. 4. - С. 40-43.

6. Малышев Л.И. Особенности ритма весеннего развития живой природы в условиях Средней Сибири // Вопросы региональной фенологии и биогеографии. Бюллетень Восточно-Сибирской фенологической комиссии. - Иркутск: Иркутское книжное изд-во, 1960. - № 1. - С. 13-18.

7. Государственный архив Республики Бурятия (ГАРБ). ФР-1738. Д. 14. Л. 11.

8. ГАРБ. ФР-1738. Д. 14. Л. 51.

9. ГАРБ. ФР-1738. Д. 14. Л. 44.

10. ГАРБ. ФР-1738. Д. 14. Л. 56.

11. Котов И.С. Май в Бурятии // Природа. - 1959. - №5. - С. 127.

12. Котов И.С. Цветение даурского рододендрона // Природа. 1956. - №8. - C. 115-120.

13. ГАРБ. ФР-1738. Д. 14. Л. 12

14. Котов И.С. Сезонные явления в природе Бурятии. Улан-Удэ: Бурятское книжное изд-во, $1968 .-2$ изд. -80 с.

\section{References}

1. Batotsyrenov E.A., Sandanov D.V. Istorija fenologicheskikh issledovanij v Buryatii [The history of phenological studies in Buryatia] // Sovremennye tendencii prostranstvennogo razvitija i prioritety obshchestvennoj geografii [Modern tendencies of spatial development and priorities of public geography]: Proceedings of the international scientific conference (Barnaul, September 12-19, 2018). - Barnaul, 2018a. - Vol. 1. - P. 261-265. [In Russ.].

2. Batotsyrenov E.A., Sandanov D.V. Vklad I.S. Kotova v fenologicheskije issledovanija $v$ Buryatii [I.S. Kotov's contribution to the phenological studies in Buryatia] // Arkhivy $\mathrm{v}$ istorii. Istoriya $\mathrm{v}$ arhivakh [Archives in history. History in archives]: Collection of scientific articles / Sc.ed. B.Ts. Zhalsanova. - Irkutsk, 2018b. - P. 123-131. [In Russ.].

3. Statistica: data analysis software system, version 10.0. StatSoft Inc., 2011. URL: http://www.statsoft.com/ (19.04.2019). [In Eng.]

4. Bulygina O.N., Razuvaev V.N., Aleksandrova T.M. Opisanije massiva dannykh sutochnoj temperatury vozdukha i kolichestva osadkov na meteorologicheskikh stanciyakh Rossii i byvshego SSSR (TTTR) [Description of daily air temperature and precipitation data on the meteorological stations of Russia and the former USSR (TTTR)]. Certificate of the governmental registration of database No. 2014620942. [In Russ.]. 
5. Kotov I.S. Tipy vjesen goroda Ulan-Ude i ego okrestnostej i kalendar' cvetenija nekotorykh vidov rastenij [Spring types of Ulan-Ude and its surroundings and blooming calendar of some plant species] // Geograficheskie pokhody (voprosy organizacii massovogo turistskogo i krajevedcheskogo dvizhenija [Geographical expeditions (issues of organizing mass tourist and local historian movement)]: Proceedings of the III $^{\text {rd }}$ scientific meeting of the geographers from Siberia and the Far East. - Irkutsk, 1966. Issue. 4. - P. 40-43. [In Russ.].

6. Malyshev L.I. Osobennosti ritma vesennego razvitija zhivoj prirody $\mathrm{v}$ usloviyakh Srednej Sibiri [Features of wild nature spring development in conditions of Middle Siberia] // Voprosy regional'noj fenologii i biogeografii [Issues of regional phenology and biogeography]. The East-Siberian phenological committee bulletin. - Irkutsk 1960. - № 1. - P.p 13-18. [In Russ.].

7. Gosudarstvenny arkhiv Respubliki Buryatija (GARB) [The state archive of the Republic of Buryatia (SARB)]. F. 1738, C. 14, L. 11. [In Russ.].

8. GARB [The state archive of the Republic of Buryatia (SARB)]. F. 1738, C. 14, L. 51. [In Russ.].

9. GARB [The state archive of the Republic of Buryatia (SARB)]. F. 1738, C. 14, L. 44. [In Russ.].

10. GARB [The state archive of the Republic of Buryatia (SARB)]. F. 1738, C. 14, L. 56. [In Russ.].

11. Kotov I.S. Maj v Buryatii [May in Buryatia] // Priroda. - 1959. №5. - P. 127. [In Russ.].

12. Kotov I.S. Cvetenije daurskogo rododendrona [The blooming of Dahurian rhododendron] // Priroda [Nature]. - 1956. - №8. - P. 115-120. [In Russ.].

13. GARB [The state archive of the Republic of Buryatia (SARB)]. F. 1738, C. 14, L. 12. [In Russ.].

14. Kotov I.S. Sezonnye javlenija v prirode Buryatii [Seasonal phenomena in nature of Buryatia]. - Ulan-Ude, 1968. $-2^{\text {nd }}$ edition. -80 p. [In Russ.]. 
DOI 10.31443/2541-8874-2019-2-10-47-52

УДК 338.45:630(091)(571.54)

Новолодская М.С.

Novolodskaya M.S.

\author{
ИСТОРИЯ ПОВСЕДНЕВНОСТИ: \\ УРОВЕНЬ ДОХОДОВ РАБОЧИХ \\ ЛЕСНОЙ ПРОМЫШЛЕННОСТИ БУРЯТИИ \\ нач. 1930 - кон. 1950-х гг.
}

\title{
THE HISTORY OF EVERYDAY LIFE: THE INCOMES LEVEL OF FOREST INDUSTRY WORKERS OF BURYATIA AT THE BEGINNING OF THE 1930s - THE END OF THE 1950s.
}

Статья посвящена изучению уровня доходов рабочих лесной промышленности Бурятии в исследуемый период. Автор анализирует структуру доходов рабочих данной отрасли.

The article is devoted to researching the incomes level of forest industry workers of Buryatia during the studied period. The author analyzes the structure of ther incomes of that industry workers.

Ключевые слова: рабочие, уровень доходов, заработная плата.

Keywords: workers, incomes level, wages.

Важным индикатором качества жизни населения являются их денежные доходы и расходы. Понятно, что у людей, живущих на заработную плату, деньги тратятся в основном на удовлетворение повседневных нужд - материальных, а также духовных потребностей. Для полного удовлетворения указанных потребностей необходимо иметь определенный доход, источником которого является заработная плата. Несомненно, на динамику доходов промышленных рабочих, в том числе лесной отрасли, влияли плановые социально-экономические изменения, характерные для страны в целом.

Структурные изменения в советской модели экономики, происходившие в годы индустриализации, оказали влияние на уровень доходов как всего населения страны, так и промышленных рабочих. К началу 1930-х гг., несмотря на то, что основные финансовые средства и ряд отраслей промышленности работали на укрепление обороны страны в третьем пятилетнем плане развития народного хозяйства СССР, определенного на 1938-1942 гг., отмечалось то, что данная пятилетка «должна обеспечить еще более высокое удовлетворение нужд и запросов трудящихся в необходимых продовольственных, промышленных товарах и услугах...» [1, с. 126]. Для улучшения материального благосостояния рабочих третьим пятилетним планом намечалось повысить уровень национального дохода на 80 \%, а заработную плату - на 67 \%. 
Советское государство предпринимало меры по эффективному использованию материальных стимулов к труду, реализующихся через систему заработной платы. Для достижения лучших результатов производственной деятельности рабочих лесной отрасли советское руководство пыталось применять различные методы стимулирования трудовой деятельности, от дифференцируемой оплаты труда в начале 1930-х гг. до предоставления «пайка» в 1940-х гг.

Известно, что основной приходной частью семейного бюджета рабочих является заработная плата, от величины которой зависит не только материальное благополучие, но и продолжительность жизни. Уровень реальной заработной платы рабочих прямым образом зависел от так называемого бюджетного набора Госплана, который составлялся специальной комиссией Статистики Труда и в своем роде приближался к прожиточному минимуму. Бюджетный индекс составлялся на основе специальной инструкции, утвержденной Госпланом СССР, ежемесячно на первое число последующего месяца. В данных статистических обследованиях давались наиболее точные исчисления о движении розничных цен за определенный период времени. Кроме этого, бюджетный индекс являлся средним расходным бюджетом рабочего.

В данный бюджетный набор входило около двадцати четырех пунктов, которые охватывали собой основные потребности трудящихся. Продукты питания - мука ржаная, мука пшеничная, картофель, лук репчатый, капуста квашеная, мясо, молоко цельное, масло коровье, масло растительное, яйца, сахар, соль и т.д. и предметы первой необходимости - сапоги простые, ситец, полотно хлопчатобумажное, керосин, мыло твердое, табак, спички и дрова.

При этом стоимость всего бюджетного набора в 1930 г. составляла 40,54 руб., а к 1940 г. его стоимость приблизилась к 90 руб. на человека, при этом продукты питания составляли примерно 70\% от всего набора [2, л. 41]. Тем не менее, бюджетный набор, определенный Госпланом, не соответствовал всем потребностям рабочих, так как уровень реальной заработной платы не поспевал за уровнем прожиточного минимума. Стоимость набора рассчитывалась на одного человека, не учитывая того, что каждый рабочий имел в среднем по два, три иждивенца.

Советское государство, понимая данный факт, направляло свои усилия на увеличение уровня заработной платы. Если среднемесячная заработная плата рабочих лесного хозяйства в 1930-1939-х гг. составляла 18,2 руб. [3, с. 148], что, конечно, было недостаточно, то в 1940 г. в целом по народному хозяйству СССР среднемесячная заработная плата работников лесной промышленности составила уже 341 руб. [4, с. 270].

Как видно, произошло увеличение среднемесячной заработной платы работников лесной отрасли в среднем примерно на $63 \%$, что приближается к реализации задачи по повышению заработной платы, поставленной третьим пятилетним планом и уровню прожиточного минимума. Конечно, судя по показателям, можно предположить, что такую заработ- 
ную плату могли получать передовики лесного производства, выполняющие и перевыполняющие производственный план.

Высокий уровень реальной заработной платы работников лесной отрасли становится более очевидным при сравнении его с аналогичными показателями рабочих других отраслей народного хозяйства. Так, например среднемесячная заработная плата работников совхозов в 1940 г. составила 220 руб., работников в сфере торговли, общественного питания 250 руб., а промышленных рабочих - 206 руб. [3, с. 138]. Полученные данные позволяют утверждать, что рабочие лесной промышленности республики, по сравнению с другими категориями населения, имели достаточно хорошую заработную плату.

Разумеется, такое резкое повышение уровня заработной платы вызывает вопросы и представляется невозможным. Однако здесь есть моменты, на которых следует остановиться более подробно. В первую очередь, данный факт был обусловлен инфляционными изменениями, связанными с дефицитом, трудностями в снабжении и «перекосами» в оплате труда. В 1947 г. была проведена денежная реформа и отмена карточной системы, значительной была эмиссия, в результате правительство несколько раз меняло государственные цены на продукты массового потребления. Возможно, что поднятие уровня реальной заработной платы привело к росту государственных цен.

Такое положение дел в стране нашло отражение и в нашей республике. В послевоенное время Министерством трудовых резервов БМАССР велась работа по повышению реальной заработной платы промышленных рабочих, в том числе рабочих лесопромышленных предприятий. О том, что имеющаяся заработная плата не удовлетворяла запросы рабочих, свидетельствуют изученные архивные материалы. Так, в приказах и в распоряжениях по хозяйственной деятельности Горхонсого ЛПХ за 1947 г. указывается то, что в Министерство трудовых резервов БМАССР поступили жалобы от рабочих Горхонского и Челутаевского ЛПХ о низкой заработной плате. Согласно распоряжению Министерства трудовых резервов от 4 сентября 1947 г. приказано увеличить заработную плату и улучшить культурно-бытовые условия рабочих [5, л. 11].

Нужно учитывать и тот факт, что заработная плата рабочих лесозаготовительных предприятий республики носила сдельный характер. По всей видимости, в годы реализации третьего пятилетнего плана оплата труда составляла по 5 рублей в день. Однако даже эти деньги иногда рабочие не получали из-за практиковавшихся обсчетов [6, л. 29].

В целом же зарплата рабочих зависела от количества заготовленной ими древесины. Так, за каждый кубометр дров, сданный на склады у железнодорожных путей, выплачивалось по 15 коп.; при условии выполнения месячного плана заготовки и вывозки древесины по 1 руб. за каждый заготовленный и вывезенный кубометр; за выполнение и перевыполнение месячного плана выплачивалась премия в размере $10 \%$ месячной заработной платы. Мастера лесозаготовительных предприятий получали 
фиксированную заработную плату: первой категории - 700 руб., второй категории - 600 руб., третьей категории - 500 руб. [7, с. 52].

В годы Великой Отечественной войны мероприятия по дальнейшему повышению уровня доходов рабочих лесной промышленности были отложены на послевоенное время, когда произошло дальнейшее повышение заработной платы. Высокие тарифные ставки были введены для трактористов и других механизаторов лесной промышленности.

Все это не могло не отразиться на уровне заработной платы рабочих лесопромышленных предприятий. Если уровень заработной платы промышленных рабочих возрос в 1951-1959 гг. на $31 \%$, то в лесной отрасли ее уровень вырос на 56 \% [8, с. 121]. Повышение заработной платы происходило за счет надбавок к зарплате за выслугу лет и выдачи премий, полученных в результате выполнения и перевыполнения производственных заданий, что должно было сыграть важную роль в восстановлении народного хозяйства страны.

На основании инструкции, утвержденной зам. министром бумажной и лесной промышленности СССР Комаровым «О выплате надбавок» от 6 октября 1949 г., было приказано в каждом леспромхозе лично директорам создать комиссию по установлению трудового стажа каждого рабочего, которым полагается надбавка за выслугу лет. Комиссии в составе трех человек должны были до января 1950 г. проверить и установить трудовой стаж на каждого рабочего. Основным документом для его установления являлись трудовые книжки или справки, выданные леспромхозом [7, с. 323]. Можно предположить, что выплата надбавок, происходившая в это время во всех лесозаготовительных предприятиях республики, существенно повысила уровень реальной заработной платы.

В дальнейшем улучшению материального обеспечения рабочих лесной отрасли в годы пятой (1951-1955 гг.) и в годы шестой (1956-1960 гг.) пятилеток способствовали мероприятия по упорядочению и повышению уровня заработной платы в народном хозяйстве страны за счет премий. Например, в квартальном статистическом отчете о выполнении плана за 1 квартал 1959 г. по Горхонскому ЛПХ указывается факт увеличения уровня средней заработной платы рабочих лесозаготовок с 81 руб. до 140 руб. в месяц за счет премий [9, л. 15]. Следовательно, можно предположить, что данная ситуация сложилась во всех лесозаготовительных предприятий республики.

Итак, в рассматриваемый период в структуре доходов преобладает заработная плата, которая имела тенденцию роста. Использование совокупного дохода в основном уходит на питание; этот вид расходов доминирует над всеми остальными. Второй расходной частью бюджета рабочих стало приобретение тканей, одежды, обуви. Нужно отметить, что с ростом заработной платы возрастает процент расходов на покупку не только продовольственных товаров, но и непродовольственных (ткани, одежды, обуви), что свидетельствует об улучшении уровня жизни. 
Тем не менее, несмотря на существенный рост заработной платы, уровень доходов рабочих лесной отрасли оставался невысоким. Следует сказать, что рабочие лесной промышленности целиком зависели от той заработной платы, которую получали. В свою очередь, советское государство, проводило ряд мер по повышению ее уровня. При этом вторая половина 50-х гг. по отношению к 1930-1940 гг. выглядит более благополучной в плане повышения уровня доходов, что прямым образом свидетельствует об улучшении уровня жизни рабочих в целом.

\section{Примечания}

1. История советского рабочего класса : в 6 т. Т. 3. Рабочий класс СССР накануне и в годы Великой Отечественной войны.1938-1945 / под ред. С. С. Хромова [и др.]. М. : Наука, 1984. 261 с.

2. Государственный архив Республики Бурятия (ГАРБ). Ф. 196. Оп. 13. Д. 212. Л. 41.

3. Труд в СССР : стат. сб. / Гос. ком. СССР по статистике. М. : Финансы и статистика, $1988.160 \mathrm{c}$.

4. Труд и заработная плата в СССР : учеб. пособие / С. А. Кузьмин [ и др.] ; под ред. Ю. В. Яковца. М. : АНХ, 1975. 370 с.

5. Администрация муниципального образования «Заиграевский район» Республики Бурятия. ФР-65. ОП. 1. Е/Х 27. Л. 11.

6. ГАРБ. Ф. 248. ОП. 11. Д. 48. Л. 29.

7. Архив Челутаевского ЛПХ. Книга приказов по личному составу, 1943-1947 гг. Приказ № 86 от 18. 10. 1948. С. 52.

8. Семенова Е. Е., Тармаханов Е. Е. Промышленность и формирование рабочих коллективов. Улан-Удэ : Изд-во БГУ, 2005. 218 с.

9. АМО «Заиграевский район» Республики Бурятия. ФР-65. ОП. 1. Е/Х 6. Л. 15.

\section{References}

1. Istorija sovetskogo rabochego klassa : v 6 t. T. 3. Rabochij klass SSSR nakanune i v gody Velikoj Otechestvennoj vojny.1938-1945 [History of the Soviet working class: in 6 vol. Vol. 3. The working class of the USSR on the eve and during the Great Patriotic war.1938-1945] / ed. by S.S. Khromov [et. al.]. M.,1984. [In Russ.].

2. Gosudarstvennyj arkhiv Respubliki Buryatija (GARB) [The state archive of the Republic of Buryatia]. F. 196. Inv. 13, C. 212. L. 41. [In Russ.].

3. Trud v SSSR : stat. sb. [Labor in the USSR: statistical compendium / Gos. kom. SSSR po statistike [State statistical committee of the USSR]. M., 1988. 160 p. [In Russ.].

4. Trud i zarabotnaja plata v SSSR : ucheb. posobije [Labor and wages in the USSR: manual] / S.A. Kuzmin et. al.; ed. by Yu.V. Yakovts. M., 1975. 370 p. [In Russ.]. 
5. Administracija municipal'nogo obrazovanija "Zaigraevskij rajon" Respubliki Buryatija [Administration of the municipality "The Zaigraevsky district" of the Republic of Buryatia]. FR-65, Inv. 1, E/X 27, L. 11. [In Russ.].

6. GARB [SARB], F. 248, Inv. 11, 48, L. 29. [In Russ.].

7. Arkhiv Chelutajevskogo LPKh. Kniga prikazov po lichnomu sostavu, 1943-1947 gg. Prikaz № 86 ot 18. 10. 1948. S. 52 [The archive of the Chelutayevsky forestry. The book of staff orders in 1943-1947. Order No. 86 from 18. 10. 1948. P. 52]. [In Russ.].

8. Semyonova E.E., Tarmakhanov E.E. Promyshlennost' i formirovanije rabochikh kollektivov [Industry and formation of the work collectives]. Ulan-Ude, 2005. 218 p. [In Russ.].

9. Administracija municipal'nogo obrazovanija "Zaigraevskij rajon" Respubliki Buryatija [Administration of the municipality "The Zaigraevsky district" of the Republic of Buryatia]. FR-65, Inv. 1, E/X 6, L. 15. [In Russ.]. 
DOI 10.31443/2541-8874-2019-2-10-53-59

УДК 069(571.17)+719

Кравцова Л.А.

Kravtsova L.A.

АКТУАЛИЗАЦИЯ ИСТОРИКО-КУЛЬТУРНОГО НАСЛЕДИЯ УГОЛЬНОЙ ОТРАСЛИ КУЗБАССА

КАК ФАКТОР ФОРМИРОВАНИЯ ШАХТЕРСКОГО ОБРАЗА КЕМЕРОВСКОЙ ОБЛАСТИ

\section{ACTUALIZATION OF THE HISTORICAL-CULTURAL HERITAGE OF THE KUZBASS COAL INDUSTRY AS A FACTOR OF FORMING THE COAL-MINING IMAGE OF THE KEMEROVO REGION}

Статья раскрывает потребность общества в трансляции шахтерской идентичности Кузбасса. Анализ актуализации историко-культурного наследия угольной отрасли доказывает важность данного процесса в формировании шахтерского образа региона. Существенную роль при этом играют государственные и ведомственные музеи угледобывающих предприятий и компаний, Кемеровский областной общественный фонд «Шахтерская Память» имени В.П. Романова, а также повсеместная распространенность исторических памятных мест, архитектурных и монументальноизобразительных памятников, тематически посвященных горнякамугольщикам.

This article examines the necessity of the society to translate the coalmining identity of the Kuzbass region. The analysis of historical-cultural heritage actualization of the coal industry shows the process importance in forming the coal-mining image of the region. The state and government department museums, museums of coal-mining companies and entities, Kemerovo regional public foundation "Coal Miner's Heritage" named after V.P. Romanov as well as all-around spread of historical landmarks, architectural sites and monuments thematically devoted to coal miners play a significant role in this process.

Ключевые слова: историко-культурное наследие угольной отрасли, шахтерский образ Кемеровской области, музейная актуализация, шахтерские памятники, шахтерская история.

Keywords: historical-cultural heritage of the coal industry, coalmining image of the Kemerovo region, museum actualization, coal-mining monuments, history of coal mining.

Специфика регионального социокультурного пространства, обусловленная совокупностью факторов, включающих исторические, географические и социально-экономические особенности, оказывает влияние на формирование его культурного потенциала и играет существенную роль в конструировании имиджа региона. Сложившийся образ Кемеров- 
ской области как шахтерского края является не только экономически обусловленным представлением данной территории крупнейшим углепромышленным центром России. Весома роль социальной активности количественно значимого на региональном уровне профессионального сообщества горняков, реализующего свою потребность в культурной идентификации и актуализации историко-культурного опыта различными формами.

В процессе становления Кемеровской области крупнейшим углепромышленным центром страны происходило накопление историко-культурного наследия угольной отрасли [5, с. 132], сохранение и популяризация которого для жителей шахтерского края стала потребностью. Важную миссию в признании подлинных доказательств территориальной и культурной идентичности региона выполняют музеи, являющиеся информационными центрами культурного наследия и социокультурным институтом познания ценностей прошлого и современности [6, с. 56]. Это обусловило потребность актуализации наследия угольной отрасли в музеях разного профиля и разной ведомственной принадлежности. Музеи Кемеровской области в процессе своего развития стали не только хранителями, интерпретаторами, но и основой актуализации историко-культурного наследия угольной отрасли.

В контексте раскрытия темы следует подчеркнуть особую роль в социокультурном пространстве Кемеровской области ведомственных и общественных музеев угледобывающих предприятий, которые являются своеобразными центрами культурной идентификации шахтерского сообщества и центрами его представительства в городах Кузбасса [4, с. 84]. Масштабные трансформации 90-х годов XX века, негативно повлиявшие на все сферы жизни общества, для угольной отрасли обернулись не только закрытием шахт и разрезов, но и утратой многих архивов, музейных коллекций, в целом материальных свидетельств развития такой промышленной сферы деятельности как угледобыча.

Стабилизация состояния угольной промышленности России в конце 90-х гг. XX в. и ее подъем в XXI в. привели к активизации формирования музейной потребности профессионального углепромышленного сообщества горняков в сохранении и пропаганде своего социального опыта, которая нашла выражение в форме создания ведомственных музеев. Этому способствовало то, что музей как «средство, которым каждый человек может воспользоваться, чтобы получить или сверить представление о своей принадлежности к той или иной системе ценностей, культуре, социальной группе» [3], для шахтеров Кемеровской области явился важным социокультурным институтом сохранения памяти, осознания «общности с себе подобными» [3].

Угольная промышленность технически и технологически даже на современном этапе остается одним из сложнейших и опасных производственных процессов. Исторически сложилось, что мемориальная составляющая наследия угольной отрасли имеет наиболее весомое обществен- 
ное значение в процессе актуализации наследия региона и формировании его шахтерского образа. Так, увековечение героизма труда шахтеров, трагической смерти горняков Кузбасса является одним из направлений деятельности Кемеровского областного общественного фонда «Шахтерская Память» имени В.П. Романова. Под эгидой этого фонда была издана не имеющая аналогов в России «Книга Памяти погибших шахтеров Кузбасса» $[1$, с. 58$]$. К сегодняшнему дню - это многотомное издание, в котором представлены сведения о 15816 трагически погибших горняков на угольных предприятиях Кузбасса. Опубликованный массив данных был сформирован усилиями ученых, инициативных групп общественников, при участии членов семей шахтеров, на основе анализа различных документальных источников, связанных с историей угольной промышленности бассейна [2, с. 294]. Тома «Книги Памяти» содержат полную информацию о каждом человеке поименно с указанием специальности, должности, участка, предприятия, даты и обстоятельств гибели. По свидетельству основного автора книги доктора исторических наук Р. С. Бикметова, процесс выхода каждого последующего тома сопровождался все большим социально значимым резонансом, а в настоящее время книга стала «семейной реликвией среди родственников погибших, <..> явилась основой для изучения далеко не парадной истории угольной отрасли региона» [2, с. 298].

Трагическая история шахтерской профессии получила в Кузбассе разнообразные формы фиксации во всех угледобывающих городах. Так, крупным авариям с тяжелыми последствиями, произошедшими на горных предприятиях Кемеровской области посвящены часовни в память погибших на производстве шахтеров Кузбасса. Например, в г. Березовском построена мемориал-часовня «Памяти погибших шахтеров»; в г. Киселевске действует часовня «Святой великомученицы Варвары»; в 2000 г. на пожертвования горожан, шахтеров построена часовня «Памяти погибших горняков» в г. Ленинске-Кузнецком; в г. Кемерово построена, освящена и открыта для прихожан в 1994 г. часовня «Всех Скорбящих Радость» [7].

Социально-исторический и культурный опыт шахтерского края получил специфическую фиксацию в форме мемориальных досок. Являясь наиболее массовой формой увековечивания исторической памяти общества [9], в процессе актуализации наследия угольной отрасли мемориальные доски символизируют трудовые подвиги горняков, прославляют выдающихся организаторов производства, основателей шахтерских династий, способствуя сохранению и преемственности ценностных ориентиров шахтерской профессии. Так, например, в шахтерском г. Киселевске общеобразовательная школа № 23 носит имя прославленного бригадира шахты «Тайжина» [7], Героя Социалистического труда Михаила Ивановича Брагина, о чем свидетельствует установленная на ней мемориальная доска; на здании одной из шахт Киселевска расположена мемориальная доска с текстом: «На шахте № 12 в период с 1933 по 1952 гг. трудился 
первый Герой Социалистического Труда, Депутат Верховного Совета СССР - Василий Романович Семыкин». В г. Новокузнецке в честь династии семьи Сизых названа улица. Василий Егорович Сизых, Иван Егорович Сизых, Михаил Егорович Сизых, Николай Егорович Сизых, Петр Егорович Сизых, Сергей Егорович Сизых трудились на кузбасских шахтах «Абашевская», «Нагорная», «Юбилейная», «Зыряновская», «Распадская», «Новокузнецкая», заслужив общественное признание трудовыми рекордами и новаторскими подходами к профессии. Мемориальная доска, установленная на жилом доме по ул. Братьев Сизых, гласит: «Улица названа в честь шахтерской династии братьев Сизых, внесших достойный вклад в развитие угольной промышленности Кузбасса и страны» [7]. В г. Ленинске-Кузнецком, богатом шахтерской историей, только в 2011 г. мемориальные доски установлены Герою Социалистического труда Алексею Тихоновичу Попову, Дмитрию Кузьмичу Придаченко, погибшему «при посадке лавы» Якову Григорьевичу Чекмареву [7]. Таким образом, мемориальные доски получили широкое распространение как форма сохранения шахтерской истории региона и актуализации наследия угольной отрасли Кузбасса.

Воплощением образа Кемеровской области являются памятникисимволы на тему шахтерского труда, значение которых заключаются в актуализации морально-нравственных смыслов профессии горняка для общества, в поддержке социального климата городов, исторически сложившихся на базе градообразующих шахт и разрезов Кузбасса. История их появления и бытования показывает, что на современном этапе эта культурная традиция, сформировавшаяся на подъеме шахтерской профессии во второй половине XX века, продолжает свое развитие в регионе и отнюдь не является пережитком пропагандисткой деятельности советского периода. Ярким примером можно считать открытие в День шахтера в 2003 г. монумента «Память шахтерам Кузбасса» в областном центре. Многоплановую идею произведения его создатель известный скульптор Эрнст Неизвестный раскрывает словами: « ... Главный пафос здесь - сопротивление. Величие тяжелейшего и опаснейшего труда, который не зря приравнивают к ратному» [7]. Есть и ряд других примеров. Так, в 2007 г. в г. Березовском была установлена скульптура «Угольная композиция с шахтерским фонарем», ключевыми элементами которой являются отбойный молоток и шахтерская лампа, символизирующие дань уважения современного поколения шахтеров своим предшественникам 50-60 гг. $\mathrm{XX}$ в., когда рекорды угледобычи устанавливались в условиях тяжелейшего физического труда. В 2011 г. по инициативе ветеранов шахты им. С. М. Кирова руководством предприятия была поддержана и реализована идея создания монумента «Шахтеру-кировцу», посвященного всем горнякам, «поднявших» одну из крупнейших шахт Кузбасса, история которой началась в 30-е гг. прошлого века в г. Ленинске-Кузнецком [7; 8].

Таким образом, актуализация историко-культурного наследия угольной отрасли в Кемеровской области явилась одним из важнейших 
факторов формирования шахтерского образа Кузбасса. Благодаря влиянию промышленно-экономической специфики, активной социокультурной и гражданской позиции общества данный процесс стал доминирующим в представлении исторических особенностей территории, а Кузбасс получил идентификацию шахтерского края. Сегодня этот имидж поддерживается новыми поколениями жителей не только в угледобывающих городах, но и в целом во всем регионе. Будущее экономическое развитие территории на долгие годы будет связано с угольной промышленностью, экологическое и техническое состояние которой не может быть оторвано от нравственных смыслов профессии горняка и преемственности ее лучших культурных традиций современным поколением шахтеров и членами их семей.

\section{Примечания}

1. Бикметов Р. С. Возвращенные имена // Уголь Кузбасса. 2010. № Март-апрель. С. 58-59.

2. Бикметов Р. С. «Книга Памяти шахтеров Кузбасса» (научнометодический, нравственно-этический и воспитательно-образовательный аспекты) // Безопасность жизнедеятельности предприятий в промышленно развитых регионах : материалы X Междунар. науч.-практ. конф. Кемерово, 2013. С. 294-298.

3. Комлев Ю. Э. Музей как социально-культурный центр региона // Аналитика культурологи. URL: http://www. Analiculturolog.ru/journal/newnumber/item/701-the-museum-as-a-cultural-center-social.html (дата обращения: 13.09.2018).

4. Кравцова Л. А. Музеи угледобывающих компаний в социокультурном пространстве Кемеровской области в начале XXI в. // Вестник Томского государственного университета. Культурология и искусствоведение. 2014. №2(14). С. 81-85.

5. Кравцова Л. А. Теоретические аспекты исследования историкокультурного наследия угольной отрасли // Вестник Кемеровского государственного университета культуры и искусств. 2013. № 2 (23). С. $127-133$.

6. Мастеница Е. Н. Регионалистика и проблемы содержания экспозиций провинциальных музеев // Современная историография и проблемы содержания исторических экспозиций музеев: по материалам круглого стола (18 мая 2001 года, г. Орёл). М. : ГИМ, 2002. С. 52-58.

7. Памятники истории и культуры Кемеровской области // Департамент культуры и национальной политики Кемеровской области : [сайт]. URL: http://okn.depcult.ru/ (дата обращения: 15.10.2018).

8. Памятные места, посвященные шахтерскому труду // Официальный сайт администрации Ленинск-кузнецкого городского округа : [сайт]. URL: $\quad$ https://leninsk-kuz.ru/den-shakhtera/pamyatnye-mestaposvyashchennye-shakhterskomu-trudu.php (дата обращения: 20.05.2019). 
9. Рысаева С. Ф. Мемориальная доска как историческое и художественное наследие города Кемерово (вторая половина XX - начало XXI вв.) // Национальное наследие и диалог культур как исток духовности современного общества. Заочные электронные конференции : [сайт]. URL: http://econf.rae.ru/article/7471 (дата обращения: 25.10.2018).

\section{References}

1. Bikmetov R. S. Vozvrashhennye imena [The returned names] // Ugol Kuzbassa [The Kuzbass Coal]. 2010. № March-April. Pp. 58-59. [In Russ.].

2. Bikmetov R. S. «Kniga Pamjati shakhterov Kuzbassa» (nauchnometodicheskij, nravstvenno-eticheskij i vospitatel'no-obrazovatel'nyj aspekty) [«The Book of Memories of the Kuzbass coal miners» (scientificmethodological, moral-ethical and insructional-educational aspects)] // Bezopasnost' zhiznedejatel'nosti predprijatij $\mathrm{v}$ promyshlenno razvitykh regionakh: materialy X Mezhdunarodnoj nauch.-prakt. konf. [Occupational industrial safety in industrially developed regions: materials of the $X^{\text {th }}$ International scientific-practical conference]. Kemerovo, 2013. Pp. 294-298. [In Russ.].

3. Komlev Yu. E. Muzej kak social'no-kul'turnyj centr regiona [Museum as a social-cultural center of the region] // Analitika kul'turologii: Elektronnoe nauchnoe izdanie [Analytics of culturology: electronic scientific edition]. URL: http://www. Analiculturolog.ru/journal/new-number/item/701the-museum-as-a-cultural-center-social.html (13.09.2018). [In Russ.].

4. Kravtsova L. A. Muzei ugledobyvayushchikh kompanij v sociokul'turnom prostranstve Kemerovskoj oblasti v nachale XXI v. [Coal mining company museums in the sociocultural space of the Kemerovo region in the beginning of the XXI ${ }^{\text {st }}$ century] // Vestnik Tomskogo gosudarstvennogo universiteta. Kul'turologiya $\mathrm{i}$ iskusstvovedenie [Tomsk State University Bulettin of Culturology and Art History]. 2014. № 2 (14). Pp. 81-85. [In Russ.].

5. Kravtsova L. A. Teoreticheskie aspekty issledovanija istorikokul'turnogo nasledija ugol'noj otrasli [Theoretical aspects of historical and cultural legacy of coal branch research] // Vestnik Kemerovskogo gosudarstvennogo universiteta kul'tury i iskusstv [Bulletin of Kemerovo State University of Culture and Arts]. 2013. № 2 (23). Pp. 127-133. [In Russ.].

6. Mastenitsa E. N. Regionalistika i problemy soderzhanija ekspozitsij provincial'nykh muzeev [Regional studies and issues of exhibit content in the regional museums] // Sovremennaya istoriografija i problemy soderzhanija istoricheskikh ekspozicij muzeev: po materialam kruglogo stola (18 maya 2001 goda, g. Orjol) [Contemporary historiography and issues of historical exhibit content of the museums: on the materials of the round table discussion (May 18, 2001, Orel]. Moscow, 2002. Pp. 52-58. [In Russ.].

7. Pamyatniki istorii i kul'tury Kemerovskoj oblasti [Monuments of history and culture of the Kemerovo region] // Departament kul'tury i 
nacional'noj politiki Kemerovskoj oblasti. [Department of Culture and National Policies of the Kemerovo region]. URL: http://okn.depcult.ru/ (15.10.2018). [In Russ.].

8. Pamyatnye mesta, posvyashchennye shakhterskomu trudu [Memorial places dedicated to coal mining] // Oficial'nyj sait administracii Leninsk-kuzneczkogo gorodskogo okruga [Leninsk-Kuznetskiy town council official site]. URL: https://leninsk-kuz.ru/den-shakhtera/pamyatnye-mestaposvyashchennye-shakhterskomu-trudu.php (20.05.2019). [In Russ.].

9. Rysaeva S. F. Memorial'naya doska kak istoricheskoe i khudozhestvennoe nasledie goroda Kemerovo (vtoraya polovina XX - nachalo XXI vv.) [Memorial plaques as a historical and artistic heritage of the Kemerovo city (second half of the $\mathrm{XX}^{\text {th }}$ century - early $\mathrm{XXI}^{\text {st }}$ century)] // Nacional'noe nasledie i dialog kul'tur kak istok dukhovnosti sovremennogo obshchestva. Zaochnye elektronnye konferencii. [National heritage and cultures dialogue as the source of contemporary society spirituality: longdistance conference materials]. URL: http://econf.rae.ru/article/7471 (25.10.2018). [In Russ.]. 


\section{кУЛЬТУРОЛОГИЯ}

DOI 10.31443/2541-8874-2019-2-10-60-66

УДК 069(571.513)

Долгополова Л.В., Суптелова А.В.

Dolgopolova L.V., Suptelova A.V.

КОМПЛЕКС БОЯРЫ-АБАКАНО-ПЕРЕВОЗ

КАК ТУРИСТИЧЕСКИЙ РЕСУРС РЕСПУБЛИКИ ХАКАСИЯ

\section{BOYARY-ABAKANO-PEREVOZ COMPLEX AS TOURIST RESOURCE OF THE REPUBLIC OF KHAKASSIA}

В статье анализируются возможности использования археологического комплекса Бояры-Абакано-Перевоз как туристического ресурса Республики Хакасия. Авторы приводят краткую историю изучения Боярского хребта. Анализируя культурно-историческую уникальность комплекса и его потенциал, авторы приходят к выводу, что включение памятников Боярского хребта в туристические маршруты позволит их популяризировать.

The article analyzes the possibilities of the archaeological complex of Boyary-Abakano-Perevoz use as tourist resource in the Republic of Khakassia. The authors briefly describe the history of studying the Boyar ridge. Analyzing cultural and historical uniqueness of the complex and its potential, the authors conclude that for promoting the monuments of the Boyar ridge they have to be included into the tourist routes.

Ключевые слова: Бояры-Абакано-Перевоз, Республика Хакасия, Большая Боярская писаница, Малая Боярская писаница, музей под открытым небом, петроглифы, культурно-исторический туризм, туристический маршрут.

Keywords: Boyary-Abakano-Perevoz, the Republic of Khakassia, Big Boyar pisanitsa, Small Boyar pisanitsa, open-air museum, petroglyphs, cultural and historical tourism, tourist route.

На территории Республики Хакасия известно большое количество памятников наскального искусства. На сегодняшний день в регионе на базе 9 местонахождений созданы музеи под открытым небом [5, с. 111122]. Среди них - всемирно известные Боярские писаницы, входящие в состав крупного петроглифического комплекса Бояры-Абакано-Перевоз.

Этот комплекс расположен между с. Троицким и д. Абакано-Перевоз и входит в состав Боярского хребта, протянувшегося перпендикулярно Красноярскому водохранилищу. На каждой из горок, являющихся отдельными памятниками, есть рисунки, а в межгорных логах - могильни- 
ки. Все эти объекты, за исключением Малой и Большой Боярских писаниц, не поставлены на государственный учет.

Кроме того, Малая и Большая Боярские писаницы, в сравнении с другими памятниками комплекса, пользуются наибольшей известностью и являются объектами культурного наследия Республики Хакасия. Малая Боярская писаница находится в 6 км от с. Троицкого, справа от дороги, ведущей в бывшую деревню Копёны [3, с. 6, 7]. Писаница была поставлена на государственную охрану 30 августа 1960 г. [7]. Большая Боярская писаница расположена приблизительно в 400 м от Малой, выше по седловине [3, с. 6, 7]. Поставлена на государственный учет 4 декабря 1974 г. [11].

В связи с уникальностью памятников с изображениями поселков тесинского времени интерес к ним специалистов проявляется с начала ХХ в. и уже стал предметом отдельного исследования [Дэвлет, 1976, с. 6]. В 1904 г. первым, кто скопировал некоторые наскальные изображения Боярского хребта, в том числе рисунки Малой Боярской, был А. В. Адрианов $[14$, с. $53-56]$.

В 1931 г. С. В. Киселев и Л. А. Евтюхова продолжили изучение Боярских писаниц. Исследователями также был сделан эстампаж фриза Малой Боярской писаницы [4, с. 254]. В работе «Древняя история Южной Сибири» (1951) С. В. Киселевым опубликована фотография писаницы с прорисовкой и описанием (с. 191).

В 1933 г. М. П. Грязновым были опубликованы изображения Малой Боярской писаницы. Исследователь воспроизвел ее с эстампажей А. В. Адрианова [2, с. 42].

В 1962 г. члены Студенческого научного общества Московского Высшего художественно-промышленного училища фотографировали и эстампировали отдельные рисунки Боярского хребта [3, с. 7].

Наиболее полное обследование выполнила М. А. Дэвлет в 1960-х гг. В 1976 г. она опубликовала прорисовки композиций Большой и фотографии Малой Боярских писаниц, а также анализ изображений этих уникальных памятников [3, с. 28-31]. В 1978 г. ею же была открыта еще одна композиция, получившая название Новая Боярская писаница [10].

В первой половине 1980-х гг. на писанице, с целью уточнения хронологии отдельных изображений, работали Н. А. Боковенко и Н. В. Леонтьев [1, с. 192].

С начала 1990-х гг. в рамках экспедиционных исследований музеязаповедника «Томская Писаница», а позднее самостоятельных, систематическим изучением петроглифов комплекса Бояры-Абакано-Перевоз занимается И. Д. Русакова [12, с. 101-112]. Исследовательницей изучены материалы 16 местонахождений из известных на тот момент 18 , девять из которых были открыты и обследованы при непосредственном ее участии [13].

Изучение Боярского хребта И. Д. Русаковой ведется и в настоящее время [14, с. 37]. Ею осуществляется учет уже обнаруженных местополо- 
жений и продолжается поиск новых. На сегодняшний день зафиксировано 22 отдельных местоположения с наскальными рисунками, включая Малую и Большую Боярские писаницы и гору Перевозную [13]. В 2016 и 2017 гг. в этих исследованиях принимали участие авторы статьи.

В 2001 г. в рамках реализации муниципальной целевой программы «Популяризация культурного наследия и развитие культурного туризма в муниципальном образовании Боградский район на годы» и на основании Постановления главы муниципального образования Боградский район от 01.01.2001 г. был создан Музей под открытым небом «Бояры. Древняя земля», который является некоммерческой организацией и входит в структуру МБУК Районный краеведческий музей [Об отчете главы..., 2011]. На официальном сайте Боградского района Республики Хакасия представлена информация о Боярской писанице как о туристическом ресурсе. Сообщается, что на территории памятника предусмотрено благоустройство: установлен рекламный щит, выполнена отсыпка дороги, созданы пешеходные мостики [9].

Тем не менее, спустя 12 лет специалистами было отмечено, что на Боярских писаницах «ничего не музеефицировано и охрана не осуществляется» [6, с. 41]. И лишь 2016 г. в ходе осмотра писаниц авторами статьи было зафиксировано, что на территории музея действительно установлен щит с информацией о юридическом статусе памятника, но при этом физическая охрана по-прежнему отсутствует, а все мероприятия по «музеефикации», как справедливо было замечено Е. А. Миклашевич, направлены лишь на туристическое использование объектов [6]. Между тем, писаница популярна как среди местного населения, так и среди приезжих туристов. Выигрышное расположение памятника обусловлено тем, что он находится вблизи с. Троицкого и к нему есть накатанная дорога. Но, тем не менее, посещение и объектов культурного наследия, и остальных памятников никем не контролируется. Такая ситуация не только не способствует сохранности петроглифов, но и наносит им вред. Так, в 2016 г. было зафиксировано, что несколько плоскостей с изображениями пункта Абакано-Певероз I кем-то подведены белой краской, которая сохраняется до настоящего времени.

Наряду с неконтролируемым посещением, в последние годы на Малую и Большую Боярские писаницы также предусмотрены организованные экскурсии: памятники включены в экскурсионный туристический маршрут, предлагаемый Хакасским национальным краеведческим музеем им. Л. Р. Кызласова. На сайте музея размещена информация для туристов о маршруте экскурсии и ее стоимости [15].

Учитывая, что кроме наскальных изображений комплекс содержит разновременные погребальные памятники, представляющие практически все исторические периоды, актуально включить в качестве объектов показа и их. Более того, активные археологические исследования в этом районе продолжаются вплоть до настоящего времени. В 11 км от с. Троицкое расположен известный средневековый могильник Копёнский чаа- 
тас. Памятник состоит из 40 курганов различных размеров. Могильник частично был раскопан в 1939 и 1940 гг. Л. А. Евтюховой и С. В. Киселевым и датирован ими VII-VIII вв. В тайниках могил обнаружены предметы быта, керамическая посуда, оружие, золотые и серебряные ювелирные украшения [4, с. 21-54].

Недалеко от чаа-таса, в 5,5 км от с. Абакано-Перевоз, находится могильник таштыкской культуры Тесинский Залив 3, датируемый исследователями I-IV вв. н.э. [16, с. 354, 355]. Памятник был открыт археологическим отрядом под руководством А. И. Готлиба. Могильные конструкции отсутствуют. На стеле, вкопанной в центре памятника, обнаружено тамгообразное изображение. При раскопках могильника были найдены керамические сосуды, роговые булавки и головные украшения (шпильки) $[16$, c. $354-357]$.

Таким образом, совокупность археологических объектов, включающих уникальные петроглифы, чаа-тас, раскопанные и нераскопанные конструкции курганов, таштыкские склепы; а также удобное расположение памятников и наличие дороги свидетельствуют, что развивать культурно-исторический туризм в этом районе перспективно. На наш взгляд, целесообразно включать данные памятники в уже созданные и создаваемые туристические маршруты. Посещение туристами археологических объектов не должно быть бесконтрольным, так как это ведет к их порче, разрушению и, в конечном счете, полному исчезновению. Данные археологические объекты могут служить для популяризации историко-культурного наследия региона, развития туризма посредством создания перспективных и познавательных туристических маршрутов, а также повышения уровня знаний, воспитания патриотизма, как у местного населения, так и у приезжих.

\section{Примечания}

1. Боковенко Н. А., Леонтьев Н. В. Обследование петроглифов на юге Красноярского края // Археологические открытия 1983 года. М. : Наука, 1985. С. 192.

2. Грязнов М. П. Боярская писаница // Проблемы истории материальной культуры. 1933. № 7-8. С. 41-45.

3. Дэвлет М. А. Большая Боярская писаница // Советская археология. 1965. № 3. С. 5-12.

4. Евтюхова Л. А., Киселёв С. В. Чаа-тас у села Копёны // Сборник статей по археологии СССР. М. : ГИМ, 1940. С. 21-54. (Тр. ГИМ, вып. $\mathrm{XI})$.

5. Миклашевич Е. А. Музеефикация памятников памятников наскального искусства в Республике Хакасия // Российская археология. 2014. № 3. C. 111-122.

6. Миклашевич Е. А., Мухарева А. Н., Бове Л. Л. Исследования петроглифической экспедиции музея-заповедника «Томская Писаница» в 
2012-2014 гг. // Учёные записки музея-заповедника «Томская Писаница». 2015. Вып. 1. С. 29-52.

7. О дальнейшем улучшении дела охраны памятников культуры в РСФСР // Правительство Республики Хакасия. URL: https://r19.ru/news/kultura/45716/ (дата обращения: 24.02.2019).

8. Об отчете главы Боградского района о результатах деятельности администрации Боградского района за 2011 год. URL: https://pandia.ru/text/77/513/3573-5.php/ (дата обращения: 24.02.2019).

9. Описание туристических ресурсов муниципального образования Боградский район // Спорт, туризм и молодёжная политика : офиц. сайт муниципал. образования «Боградский район Республики Хакасия». URL: http://bograd-web.ru/molod_sport_turizm/tourism/176-opisanieturistskih-resursov-municipalnogo-obrazovaniya-bogradskiy-rayon.html/. (дата обращения: 6.03.2019).

10. Петроглифы Северной Евразии // Боярские писаницы. URL: http://rockart-studies.ru/?page_id=5754/_дата обращения 3.03.2019).

11. В Хакассии осуществляется мониторинг объектов культурного наследия // Правительство Республики Хакасия. URL: https://r19.ru/news/kultura/45716/ . (дата обращения: 24.02.19).

12. Русакова И. Д. Новый памятник наскального искусства на Енисее (писаница у д. Абакано-Перевоз в Хакасии) // Наскальное искусство Азии. Кемерово : Кузбассвузиздат, 1997. Вып. 2. С. 101-112.

13. Русакова И. Д. Петроглифический комплекс «Бояры-АбаканоПеревоз» в Хакасии и его место в природно-историческом ландшафте : автореф. дис. ... канд. ист. наук. Кемерово, 2003. 19с.

14. Русакова И. Д. Работы на петроглифическом комплексе БоярыАбакано-Перевоз в Хакасии в 2017 г. // Учёные записки музея-заповедника «Томская писаница». 2018. Вып. 7. С. 36-41.

15. Хакасский национальный краеведческий музей имени Л. Р. Кузласова.

URL:

http://nhkm.ru/index.php?option=com_content\&view=article $\& \mathrm{id}=340 \&$ Itemid=324\&lang=ru/ (дата обращения: 07.03.2019).

16. Начало изучения таштыкского грунтового могильника Тесинский Залив-3 (Боградский район, Республика Хакасия) / Митько О. А., Худяков Ю. С., Скобелев С. Г., Поселянин А. И., Половников И. С. // Проблемы археологии, этнографии, антропологии Сибири и сопредельных территорий. Новосибирск : Изд-во ИАЭТ СОРАН, 2017. Т. 23. С. 354-357.

\section{References}

1. Bokovenko N.A., Leontyev N.V. Obsledovanije petroglifov na juge Krasnoyarskogo kraja [The study of petroglyphs in the south of the Krasnoyarsk region] // Arheologicheskie otkrytija 1983 goda [Archaeological discoveries of 1983]. M., 1985. Pp. 192. [In Russ.] 
2. Gryaznov M.P. Boyarskaja pisanica [The Boyar pisanitsa] // Problemy istorii material'noj kul'tury [Issues of history of material culture]. 1933. № 7-8. Pp. 41-45. [In Russ.]

3. Devlet M.A. Bol'shaya Boyarskaya pisanica [Big Boyar pisanitsa] // Sovetskaya arkheologija [The Soviet archaeology]. 1965. № 3. Pp. 5-12. [In Russ.]

4. Evtyukhova L.A., Kiselev S.V. Chaa-tas u sela Kopjony [Chaa-tas nearby Kopyona village] // Sbornik statej po arkheologii SSSR [Collection of the archaeology works of the USSR]. M., 1940. №XI. Pp. 21-54. [In Russ.]

5. Miklashevich E.A. Muzeefikacija pamyatnikov naskal'nogo iskusstva $\mathrm{v}$ Respublike Khakasija [Museumification of rock art monuments in the Republic of Khakassia]// Rossijskaja arkheologija [The Russian archaeology] 2014. № 3. Pp. 111-122. [In Russ.]

6. Miklashevich E.A., Mukhareva A.N., Bove L.L. Issledovanija petroglificheskoj ekspeditsii muzeja-zapovednika «Tomskaja Pisanica» V 2012-2014 gg. [The research of the reserve museum "Tomsk Pisanitsa by the petroglyph expedition] // Uchenye zapiski muzeja-zapovednika "Tomskaja Pisanica" [Memoirs of the museum reserve "Tomsk Pisanitsa"]. 2015. № 1. Pp. 29-52. [In Russ.]

7. O dal'nejshem uluchshenii dela okhrany pamjatnikov kul'tury $\mathrm{v}$ RSFSR [On the further improvement of cultural monuments safeguarding in the RSFSR] // Pravite'stvo Respubliki Khakasija [The government of the Republic of Khakassia] URL: https://r-19.ru/news/kultura/45716/ (24.02.2019). [In Russ.]

8. Ob otchete glavy Bogradskogo rajona o rezul'tatakh dejatel'nosti administracii Bogradskogo rajona za 2011 god [About the report of the head of the Bograd district on the activities results of the administration of the Bograd district in 2011] URL: https://pandia.ru/text/77/513/3573-5.php/ (24.02.2019). [In Russ.]

9. Opisanije turisticheskikh resursov municipal'nogo obrazovanija Bogradskij rajon [The description of the tourist resources of the municipality «The Bograd district»] // Sport, turizm i molodezhnaoa politika: ofic. sait municipal. obrazovanija "Bogradskij rajon Respubliki Khakasija" [Sport, tourism and youth policy: official cite of the municipality «The Bograd district of the Republic of Khakassia] URL: http://bogradweb.ru/molod_sport_turizm/tourism/176-opisanie-turistskih-resursovmunicipalnogo-obrazovaniya-bogradskiy-rayon.html/. (6.03.2019). [In Russ.]

10. Petroglify Severnoj Evrazii [The petroglyphs of the North Eurasia] //Boyarskije pisanicy [Boyar pisanitsas]. URL: http://rockartstudies.ru/?page_id=5754/_(3.03.2019). [In Russ.]

11. V Khakassii osushchestvljaetsja monitoring ob'jektov kul'turnogo nasledija [The monitoring of the cultural heritage objects is being done in Khakassia] // Pravitel'stvo Respubliki Khakasija [The government of the Republic of Khakassia]. URL: https://r-19.ru/news/kultura/45716/. (24.02.19). [In Russ.] 
12. Rusakova I.D. Novyj pamjatnik naskal'nogo iskusstva na Yenisee (pisanica u d. Abakano-Perevoz v Khakasii [The new monument of rock art on the Yenisei (pisanitsa at Abakano-Perevoz in Khakassia] // Naskal'noe iskusstvo Azii [Rock art of Asia]. Kemerovo, 1997. № 2. Pp. 101-112. [In Russ.]

13. Rusakova I.D. Petrogloficheskij kompleks "Boyary-Abakano v Khakasii i ego mesto $\mathrm{v}$ prirodno-istoricheskom landshafte [Petroglyph complex "Boyary-Abakano-Perevoz" in Khakassia and its place in naturalhistorical landscape] // avtoref. dis. ... kand. ist. nauk [dissertation thesis ...candidate of historical sciences]. Kemerovo, 2003. 19 p. [In Russ.]

14. Rusakova I.D. Raboty na petroglificheskom komplekse BoyaryAbakano-Perevoz v Khakasii v 2017 g. [The work on the petroglyph complex Boyary-Abakano-Perevoz in Khakassia in 2017] // Uchenye zapiski muzejazapovednika "Tomskaya Pisanica" [Memoirs of the museum reserve "Tomsk Pisanitsa”]. 2018. № 7. Pp. 36-41. [In Russ.]

15. Khakasskij nacional'nyj kraevedcheskij muzej imeni L.P. Kuzlasova [Khakass national history museum named after L.P. Kuzlasov. URL: $\quad \mathrm{http}: / / \mathrm{nhkm} . \mathrm{ru} / \mathrm{index}$. php?option=com_content\&view=article $\& \mathrm{id}=340 \&$ Itemid $=324 \&$ lang=ru/ (07.03.2019). [In Russ.]

16. Nachalo izuchenija tashtykskogo gruntovogo mogil'nika Tesinskij Zaliv-3 (The Bogradskij rajon, Respublika Khakasija) [The beginning of the research of the the Tashtyk ground burial Tesinsky Bay-3 (the Bogradsky district, Republic of Khakassia / Mitko O.A., Khudyakov Yu.S., Skobelev S.G., Poselyanin A.I., Polovnikov I.S.] // Problemy arkheologii, etnografii, antropologii Sibiri i sopredel'nykh territorij [Issues of archaeology, ethnography, anthropology of Siberia and adjacent territories].Novosibirsk, 2017. Vol. 23. Pp. 354-357. [In Russ.] 
DOI 10.31443/2541-8874-2019-2-10-67-78

УДК 069(571.52)

Донгак В.Ч.

Dongak V.Ch.

\section{ОБЗОР КОЛЛЕКЦИЙ: МЕЛКИЕ МЛЕКОПИТАЮЩИЕ ТАКСИДЕРМИЧЕСКИХ РАБОТ В ФОНДАХ НАЦИОНАЛЬНОГО МУЗЕЯ РЕСПУБЛИКИ ТЫВА

\author{
THE COLLECTION REVIEW: TAXIDERMY WORKS ON SMALL \\ MAMMALS BASED ON THE FUND MATERIALS OF THE \\ NATIONAL MUSEUM OF THE REPUBLIC OF TUVA
}

В статье рассматривается история комплектования коллекций мелких млекопитающих, дана краткая характеристика видовых разнообразий.

The article deals with the history of compiling the collections of small mammals, presents a brief description of species diversity.

Ключевые слова: Национальный музей им. Алдан-Маадыр Республики Тыва, таксидермист, мелкие млекопитающие, коллекция, экспозиция, диорама, комплектование музейного фонда, хранение музейных предметов, экспонирования.

Keywords: the National Museum named after Aldan-Maadyr in the Tuva Republic, taxidermist, small mammals, collection, exposition, diorama, compiling a museum fund, storage of museum objects, exhibiting.

Мелкие млекопитающие в силу своей многочисленности являются важнейшим элементом экосистем, а также массовыми потребителями растительности и насекомых. Относительная многочисленность, а также широкое распространение делают их более удобной моделью для изучения вопросов популяционной экологии [1]. Данная группа животных благодаря высокой численности и широкому распространению имеет большое практическое значение и является неотъемлемой частью практически любого биоценоза [8]. Эти животные являются основным кормовым ресурсом для многих млекопитающих, дневных и ночных хищных птиц, а также некоторых пресмыкающихся, норы грызунов являются убежищем для других животных - ящериц, змей [3].

Животный мир Тувы, занимающей промежуточное положение между Восточной Сибирью и Центральной Азией, весьма разнообразен. Этому способствует мозаичность ландшафтов, создающих различные экологические условия для существования животных: сухие и полупустыни, светло- и темнохвойные леса, субальпийские и альпийские луга и горная тундра. В Туве насчитывается 136 видов млекопитающих. Многие животные полупыстынь и пустынь - дзерен, корсак, заяц-толай, даурская пищуха, ушастый еж, мохнатый тушканчик и другие виды, обитающие в 
Убсунурской котловине, не могли преодолеть этой преграды и севернее хребта Танну-Ола не встречаются $[2,5,6,7,10]$.

В фондах Национального музея Республики Тыва представлено разнообразие и богатство региональной флоры и фауны. В фондах отдела природы имеются чучела практически всех представителей отряда млекопитающих, изготовленные мастером, известным таксидермистом Сибири Иваном Матвеевичем Путинцевым. В нашей статье предпринята попытка дать обзор таксидермических работ мелких млекопитающих, хранящихся в музейных фондах.

История комплектования фондов млекопитающих началась с 1950х гг. Согласно первой книге поступления (ОФ) музейных предметов регистрация коллекций происходит с 1954 г. Сегодня в фондах хранятся 222 чучела млекопитающих, относящихся к 34 видам, 10 семействам, 4 отрядам. Млекопитающие зафиксированы в Книгах поступлениях под №№ 1 , $2,3,7,8,9,11,12,16$ основного и научно-вспомогательного фонда. Одним из первых поступивших является млекопитающее под №204 - выдра. Заметное место занимает коллекция млекопитающих, состоящая из серии экспонатов, добытых из районов Республики Тыва: Монгун-Тайгинский, Эрзинский, Пий-Хемский, Овюрский, Кызылский, Сут-Хольский. Все коллекции млекопитающих были сформированы в последние десятилетия XX века И.М. Путинцевым. Тушки млекопитающих (98 ед.) поступили в музей от преподавателя Тувинского Государственного университета Николая Ивановича Путинцева, который в результате многочисленных научных экспедиций во все уголки республики собрал значительный материал по видовому составу и экологии многих групп животных Тувы. Сегодня коллекция млекопитающих представляет собой одну из самых ценных и востребованных естественнонаучных коллекций тувинского музея.

Основная часть (83 \%) мелких млекопитающих была передана в разные годы в дар музею И.М. Путинцевым. Единичные экземпляры были выполнены Д.Н. Зверевым и В.И. Шмаковым. Особая роль и непосредственно активное участие по сбору материалов для комплектования коллекций мелких млекопитающих принадлежит сотрудникам отдела природы Национального музея. Пополнение фондов музея таксидермическими работами мелких млекопитающих шло на общих основаниях, в качестве дара, передачи и закупки.

Рассмотрим таксидермические работы по основным видам мелких млекопитающих, хранящихся в фондах Национального музея РТ.

Отряд Грызуны (сем. мышовковые, сем. тушканчики, сем. хомяковые, сем. мышиные, сем. беличьи, род сурки, сем. бобровые). К этому отряду относятся млекопитающие мелких и средних размеров. Лапы грызунов пятипалые, реже четырехпалые. На каждой челюсти по два резца, лишенные корней и растущие в течение всей жизни. Клыков нет. Обитают в различных ландшафтах и приспособлены к разнообразным условиям существования. Есть наземные, древесные, полуводные, подземные 
грызуны. Приспособлены к различным способам передвижения: бег, прыжки, планирующий полет, продвижение в почве.

Семейство бобровых. Среди грызунов, обитающих в нашей стране, бобр - самый крупный представитель, его вес превышает 20 кг. Животные приспособлены к обитанию в замерзающих зимой водоемах. Полуводному образу жизни отвечают его форма тела, строение волосяного покрова, хвоста, ротового аппарата. Задние лапы короткие, пятипалые, между пальцами имеется кожистая плавательная перепонка [3].

В зале №7 Национального музея РТ «Тайга: в единстве с природой» в разделе «Сезонные изменения в природе» представлена единственно сохранившаяся по всей Сибири колония Азасских бобров. Это типичные обитатели рек и озер, берега которых поросли ивой, осиной, тополем, березой и другими лиственными деревьями, и кустарниками. Тувинский бобр занесен в Красную книгу Республики Тыва как редкий вид и охраняется в Государственном природном заповеднике «Азас». Основная цель создания заповедника - это сохранение и изучение в естественном состоянии уникальных экосистем, редких и исчезающих видов растений и животных, эталонных горных ландшафтов северо-восточной Тувы $[4,9]$.

Обитатели cmenных котловин приспособились к условиям жизни на открытых пространствах. Большинство из них - подземные обитатели, а копание нор это основное занятие степных млекопитающих. Поэтому у них длинные формы тел, мощные когти передних лап, маскирующая окраска, ночной образ жизни, способность впадать в спячку. Крупные степные животные хорошо бегают.

Хорь обыкновенный - Kырза - Mustela - небольшой зверек, обитает в степной и лесостепной местности, часто встречается на лугах и зарослях кустарников. Поселяется в норах сусликов, раскапывая их. Питается степными грызунами, приносит пользу сельскому хозяйству, истребляя массу сусликов и других грызунов [4].

Монгольский сурок - Тарбаган - Marmota sibiric, встречается в степях от предгорий до высоты 3800 м над уровнем моря, в том числе на горных, альпийских лугах, в высокогорье, горных редколесьях. Монгольский сурок из Тувы и Забайкальского края входит в Красную книгу РФ [9]. Популяция сурка Юго-Восточного Забайкалья находится под угрозой исчезновения; в Туве и Северо-Восточном Забайкалье также их численность сокращается.

Спячка у сурков длится с последней декады сентября до конца марта-начала апреля, молодые появляются на поверхности во второй половине июня. В прошлом сурок являлся популярным объектом спортивной и традиционной охоты [4]. В Туве встречаются два вида сурков: алтайский и монгольский. В музее они экспонируются в первом зале второго этажа в диораме «Высокогорные экосистемы». Однако сегодня требуются меры по сохранению как находящегося под угрозой исчезновения и сокращающегося в численности вида. Сурок добывается ловушками и 
капканами, иногда при ружейной охоте. Товарами являются мех (шкурки) и жир всех видов сурков, без особого различия. Жир используется как лечебное средство.

Пятипальй карликовый тушканчик - Беш салаальгг алак-таагы Cardiocranius paradoxus, встречается на юге Тувы. Обитает в щебнистых полупустынях с участками песков и разреженной растительностью. На поверхности выходит после захода солнца и активен всю ночь. Питается семенами, зелеными частями растений, особенно в засуху, насекомыми. Усы очень длинные. Задние ноги пятипалые, со «щеткой» из жестких волос на ступне. Хвост очень толстый, поскольку в нем откладывается жир на зиму. Кроме того, хвост используется как объект осязания (он покрыт чувствительными волосками) и как опора при рытье нор. Забравшись в нору, тушканчик хвостом сгребает к ней песок. Умеет лазать по кустарникам. При опасности затаивается или быстро скрывается в норе. Оба вида занесены в Красную книгу России и Тувы. Находится под охраной Государственного биосферного заповедника «Убсунурская котловина» как неопределённый по статусу и как сокращающийся в численности вид [4].

Насекомоядные - самая древняя группа млекопитающих в нашей стране, они появились на Земле, еще во времена первых динозавров. Это ежи, кроты, землеройки и выхухоли - мелкие зверьки, живущие на земле, в почве, лесной подстилке или в пресных водоемах. Все они плохо видят и находят добычу по запаху или звуку. Кроме насекомых они едят всех мелких животных, которых могут поймать, а иногда также семена и сочные части растений. Насекомоядные - носители инфекций, опасных для человека, клещевого энцефалита, лептоспироза и т.д.

В Туве встречается 2 вида ежей: обыкновенный еж-Чараа-чеченErinaceus europaeus u ушастый еж - Кулактыг чараа-чечен Hemiechinus auritus. Одно чучело ежа экспонируется в холле, в вводном зале в честь 85-летия Национального музея Республики Тыва.

Ежи отличаются от всех зверей по колючей спине. При встрече с хищником ёж сворачивается в колючий колобок. Ежи обладают очень высокой устойчивостью к некоторым ядам, в частности к змеиному. Колючий панцирь не всегда спасает ежа от хищников. Медведь, барсук, степной орел и филин могут развернуть зверька.

Кроты - мелкие подземные зверьки с мощными широкими передними лапами и маленькими глазками, ушных раковин нет. Мех короткий, мягкий, одинаково легко ложится и вперед, и назад. Такой мех позволяет кроту свободно двигаться по своим ходам в любую сторону. Кроты активны круглые сутки и круглый год, но зимние ходы лежат очень глубоко ниже уровня промерзания почвы или под снегом. Мех кротов - ценное пушное сырье. Запах кротов привлекает дождевых червей, которые сами собираются в ходах, так что кроту остается только «собирать урожай». Многолетняя роющая деятельность кротов приводит к улучшению почвы и способствует возобновлению леса [3]. 
В музее хранятся тушки 2 видов кротов: обыкновенный крот - дедир даван - Talpa eиropаеа и алтайский крот - алтай дедир-даваны. Одна единица экспонируется в первом зале в разделе «Природные зоны Тувы» и 2 вида тушек экспонируются в зале №7, в диораме «Таёжные экосистемы».

Таблица 1

Реестр таксидермических работ мелких млекопитающих Национального музея Республики Тыва

\begin{tabular}{|c|c|c|c|c|c|}
\hline № & № КП & $\begin{array}{l}\text { Дата за- } \\
\text { писи }\end{array}$ & $\begin{array}{l}\text { Источник по- } \\
\text { ступления }\end{array}$ & Наименование & $\begin{array}{c}\text { Кол } \\
\text { во }\end{array}$ \\
\hline 1 & 204 & $\begin{array}{l}17.03 . \\
1954 \text { г }\end{array}$ & & $\begin{array}{l}\text { Выдра (Lutra lutra) - отряд } \\
\text { хищные, семейство куньи. }\end{array}$ & 1 \\
\hline 2 & 229 & & & $\begin{array}{l}\text { Бобр (Castor fiber) - отряд } \\
\text { грызуны, семейство бобро- } \\
\text { вые. }\end{array}$ & 1 \\
\hline 3 & 2355 & & & $\begin{array}{l}\text { Бобр (Castor fiber) - отряд } \\
\text { грызуны, семейство бобро- } \\
\text { вые. }\end{array}$ & 1 \\
\hline 4 & 2357 & & & $\begin{array}{l}\text { Рысь (Lynx lynx) - Отряд } \\
\text { хищные, семейство кошачьи. }\end{array}$ & 1 \\
\hline 5 & 2366 & & & $\begin{array}{l}\text { Бобр (Castor fiber) - отряд } \\
\text { грызуны, семейство бобро- } \\
\text { вые. }\end{array}$ & 1 \\
\hline 6 & 2048 & & & $\begin{array}{l}\text { Заяц (Lepus) - отряд зайцеоб- } \\
\text { разные, семейство зайцевые. }\end{array}$ & 1 \\
\hline 7 & 2049 & & & $\begin{array}{l}\text { Хомяк (Cricetus cricetus) - от- } \\
\text { ряд грызуны, семейство хо- } \\
\text { мяковые. }\end{array}$ & 1 \\
\hline 8 & 2050 & & . & $\begin{array}{l}\text { Тушканчик (Dipodidae) - от- } \\
\text { ряд грызуны, семейство туш- } \\
\text { канчиковые. }\end{array}$ & 1 \\
\hline 9 & 2365 & $\begin{array}{l}20.03 . \\
1955 \text { г. }\end{array}$ & & $\begin{array}{l}\text { Росомаха (Gulo gulo) - отряд } \\
\text { хищные, семейство куньи. }\end{array}$ & 1 \\
\hline 10 & 2367 & & & $\begin{array}{l}\text { Рысь (Lynx lynx) - Отряд } \\
\text { хищные, семейство кошачьи. }\end{array}$ & 1 \\
\hline 11 & 2368 & & & $\begin{array}{l}\text { Соболь (Martes zibellina) - } \\
\text { отряд хищные, семейство ку- } \\
\text { ньи. }\end{array}$ & 1 \\
\hline 12 & 2934 & $\begin{array}{l}13.05 .1954 \\
\text { г. }\end{array}$ & От Похорукова & $\begin{array}{l}\text { Соболь (Martes zibellina) - } \\
\text { отряд хищные, семейство ку- } \\
\text { ньи. }\end{array}$ & 1 \\
\hline 13 & 2936 & & & $\begin{array}{l}\text { Колонок (Mustela sibirica) - } \\
\text { отряд хищные, семейство ку- } \\
\text { ньи. }\end{array}$ & 1 \\
\hline 14 & 2937 & & & $\begin{array}{l}\text { Соболь (Martes zibellina) - } \\
\text { отряд хищные, семейство ку- } \\
\text { ньи. }\end{array}$ & 1 \\
\hline 15 & 2939 & & & $\begin{array}{l}\text { Лиса (Vulpes) - семейство } \\
\text { псовое. }\end{array}$ & 1 \\
\hline 16 & 2940 & & & $\begin{array}{l}\text { Заяц (Lepus) - отряд зайцеоб- } \\
\text { разные, семейство зайцевые. }\end{array}$ & 1 \\
\hline
\end{tabular}




\begin{tabular}{|c|c|c|c|c|}
\hline $\begin{array}{l}17- \\
20\end{array}$ & 2964 & $\begin{array}{l}08.04 . \\
1958 \Gamma .\end{array}$ & $\begin{array}{l}\text { Белка (Sciurus) - отряд гры- } \\
\text { зуны, семейство беличьи. }\end{array}$ & 4 \\
\hline $\begin{array}{l}21- \\
22\end{array}$ & 2965 & & $\begin{array}{l}\text { Колонок (Mustela sibirica) - } \\
\text { отряд хищные, семейство ку- } \\
\text { ньи. }\end{array}$ & 2 \\
\hline 23 & 2966 & & $\begin{array}{l}\text { Горностай (Mustela erminea) } \\
\text { - отряд хищные, семейство } \\
\text { куньи. }\end{array}$ & 1 \\
\hline $\begin{array}{l}24- \\
26\end{array}$ & 3163 & & $\begin{array}{l}\text { Ондатра (Ondatra zibethicus) - } \\
\text { отряд грызуны, семейство хо- } \\
\text { мяковые. }\end{array}$ & 3 \\
\hline 27 & 3290 & $\begin{array}{l}29.11 . \\
1958 \text { г. }\end{array}$ & $\begin{array}{l}\text { Бурундук (Tamias) - отряд } \\
\text { грызуны, семейство беличьи. }\end{array}$ & 1 \\
\hline 28 & 3291 & & $\begin{array}{l}\text { Тарбаган-Сурок (Marmota) - } \\
\text { отряд грызуны, семейство бе- } \\
\text { личьи. }\end{array}$ & 1 \\
\hline 29 & 3306 & & $\begin{array}{l}\text { Хорь перевязка (Vormela } \\
\text { peregusna) - отряд хищные, } \\
\text { семейство куньи. }\end{array}$ & 1 \\
\hline 30 & 3326 & $\begin{array}{l}11.02 . \\
1959 \text { г. }\end{array}$ & $\begin{array}{l}\text { Белка (Sciurus) - отряд гры- } \\
\text { зуны, семейство беличьи. }\end{array}$ & 1 \\
\hline 31 & 3343 & & $\begin{array}{l}\text { Манул (Otocolobus manul) - } \\
\text { отряд хищные, семейство ко- } \\
\text { шачьи. }\end{array}$ & 1 \\
\hline 32 & 3344 & & $\begin{array}{l}\text { Белка-летяга (Pteromys } \\
\text { volans) - отряд грызуны, ce- } \\
\text { мейство беличьи. }\end{array}$ & 1 \\
\hline 33 & 3446 & $13.05 .1959 \Gamma$ & $\begin{array}{l}\text { Ежик (Erinaceus europaeus) - } \\
\text { отряд насекомоядные, семей- } \\
\text { ство ежовые. }\end{array}$ & 1 \\
\hline 34 & 3509 & $\begin{array}{l}08.09 . \\
1959 \text { г. }\end{array}$ & $\begin{array}{l}\text { Хорь (Mustela putorius) - от- } \\
\text { ряд хищные, семейство ку- } \\
\text { ньи }\end{array}$ & 1 \\
\hline $\begin{array}{l}35- \\
36\end{array}$ & 3512 & $\begin{array}{l}23.09 . \\
1959 \text { г. }\end{array}$ & $\begin{array}{l}\text { Суслик (Spermophilus) - от- } \\
\text { ряд грызуны, семейство бе- } \\
\text { личьи. }\end{array}$ & 2 \\
\hline 37 & 3513 & & $\begin{array}{l}\text { Крыса водяная (Rattus) - от- } \\
\text { ряд грызуны, семейство мы- } \\
\text { шиные. }\end{array}$ & 1 \\
\hline 38 & 3608 & & $\begin{array}{l}\text { Тарбаган-Сурок (Marmota) - } \\
\text { отряд грызуны, семейство бе- } \\
\text { личьи. }\end{array}$ & 1 \\
\hline 39 & 3701 & $\begin{array}{l}28.12 . \\
1960 \text { г }\end{array}$ & $\begin{array}{l}\text { Барсук (Meles meles) - отряд } \\
\text { грызуны, семейство куньи. }\end{array}$ & 1 \\
\hline 40 & 3706 & & Хомяк & 1 \\
\hline 41 & 3754 & $\begin{aligned} 04.05 . \\
1961 \text { г. }\end{aligned}$ & $\begin{array}{l}\text { Заяц (Lepus) - отряд зайцеоб- } \\
\text { разные, семейство зайцевые. }\end{array}$ & 1 \\
\hline 42 & 3755 & & $\begin{array}{l}\text { Хорь (Mustela putorius) - от- } \\
\text { ряд хищные, семейство ку- } \\
\text { ньи. }\end{array}$ & 1 \\
\hline $\begin{array}{l}43- \\
44\end{array}$ & 3859 & $\begin{array}{l}05.07 . \\
1961 \text { г. }\end{array}$ & $\begin{array}{l}\text { Мышь серая (Mus musculus) - } \\
\text { отряд грызуны, семейство } \\
\text { мышиные. }\end{array}$ & 2 \\
\hline
\end{tabular}




\begin{tabular}{|c|c|c|c|c|}
\hline 45 & 3895 & $\begin{array}{l}12.10 . \\
1961 \text { г. }\end{array}$ & $\begin{array}{l}\text { Тушканчик (Dipodidae) - от- } \\
\text { ряд грызуны, семейство туш- } \\
\text { канчиковые. }\end{array}$ & 1 \\
\hline 46 & 3896 & & $\begin{array}{l}\text { Тушканчик (Dipodidae) - от- } \\
\text { ряд грызуны, семейство туш- } \\
\text { канчиковые. }\end{array}$ & 1 \\
\hline 47 & 3905 & & $\begin{array}{l}\text { Тушканчик (Dipodidae) -от- } \\
\text { ряд грызуны, семейство туш- } \\
\text { канчиковые. }\end{array}$ & 1 \\
\hline 48 & 3906 & & $\begin{array}{l}\text { Хомяки́ (Cricetinae) - отряд } \\
\text { грызуны, семейства хомяко- } \\
\text { вых. }\end{array}$ & 1 \\
\hline $\begin{array}{c}49- \\
54\end{array}$ & 3907 & & $\begin{array}{l}\text { Мышь серая (Mus musculus) - } \\
\text { отряд грызуны, семейство } \\
\text { мышиные. }\end{array}$ & 6 \\
\hline 55 & 3908 & & $\begin{array}{l}\text { Тарбаган-Сурок (Marmota) - } \\
\text { отряд грызуны, семейство бе- } \\
\text { личьи. }\end{array}$ & 1 \\
\hline 56 & 3959 & $\begin{array}{l}25.05 . \\
1962 \text { г. }\end{array}$ & $\begin{array}{l}\text { Ласка (Mustela nivalis) - от- } \\
\text { ряд хищные, семейство ку- } \\
\text { ньи. }\end{array}$ & 1 \\
\hline 57 & 4388 & & $\begin{array}{l}\text { Белка (Sciurus) - отряд гры- } \\
\text { зуны, семейство беличьи. }\end{array}$ & 1 \\
\hline 58 & 4389 & & $\begin{array}{l}\text { Белка (Sciurus) - отряд гры- } \\
\text { зуны, семейство беличьи. }\end{array}$ & 1 \\
\hline 59 & 4569 & $\begin{array}{l}08.02 . \\
1967 \text { г. }\end{array}$ & $\begin{array}{l}\text { Соболь (Martes zibellina) - } \\
\text { отряд хищные, семейство ку- } \\
\text { ньи. }\end{array}$ & 1 \\
\hline 60 & 5904 & $\begin{array}{l}08.12 . \\
1973 \text { г. }\end{array}$ & $\begin{array}{l}\text { Бурундук (Tamias) - отряд } \\
\text { грызуны, семейство беличьи. }\end{array}$ & 1 \\
\hline 61 & 6931 & $\begin{array}{l}22.12 . \\
1977 \text { г. }\end{array}$ & $\begin{array}{l}\text { Белка-летяга (Pteromys } \\
\text { volans) - отряд грызуны, ce- } \\
\text { мейство беличьи. }\end{array}$ & 1 \\
\hline $\begin{array}{c}62- \\
65\end{array}$ & 6944 & & $\begin{array}{l}\text { Суслик (Spermophilus) - от- } \\
\text { ряд грызуны, семейство бе- } \\
\text { личьи. }\end{array}$ & 4 \\
\hline $\begin{array}{c}66- \\
67 \\
\end{array}$ & 6957 & & $\begin{array}{l}\text { Белка (Sciurus) - отряд гры- } \\
\text { зуны, семейство беличьи. }\end{array}$ & 2 \\
\hline $\begin{array}{c}68- \\
70\end{array}$ & 7227 & $\begin{array}{l}23.11 . \\
1978 \text { г. }\end{array}$ & $\begin{array}{l}\text { Заяц (Lepus) - отряд зайцеоб- } \\
\text { разные, семейство зайцевые. }\end{array}$ & 3 \\
\hline 71 & 7470 & $\begin{array}{l}09.08 . \\
1979 \text { г. }\end{array}$ & $\begin{array}{l}\text { Заяц (Lepus) - отряд зайцеоб- } \\
\text { разные, семейство зайцевые. }\end{array}$ & 1 \\
\hline 72 & 7458 & & $\begin{array}{l}\text { Хорь (Mustela putorius) - от- } \\
\text { ряд хищные, семейство ку- } \\
\text { ньи. }\end{array}$ & 1 \\
\hline 73 & 7746 & $\begin{array}{l}16.12 . \\
1980 \text { г. }\end{array}$ & $\begin{array}{l}\text { Колонок (Mustela sibirica) - } \\
\text { отряд хищные, семейство ку- } \\
\text { ньи. }\end{array}$ & 1 \\
\hline 74 & 8013 & & $\begin{array}{l}\text { Белка-летяга (Pteromys } \\
\text { volans) - отряд грызуны, ce- } \\
\text { мейство беличьи. }\end{array}$ & 1 \\
\hline
\end{tabular}




\begin{tabular}{|c|c|c|c|c|}
\hline 75 & 8014 & & $\begin{array}{l}\text { Норка (Mustela lutreola) - от- } \\
\text { ряд хищные, семейство ку- } \\
\text { ньи. }\end{array}$ & 1 \\
\hline 76 & 8226 & & $\begin{array}{l}\text { Крот (Talpidae) - отряд насе- } \\
\text { комоядные, семейство крото- } \\
\text { вые. }\end{array}$ & 1 \\
\hline $\begin{array}{l}77- \\
78\end{array}$ & 9197 & $\begin{array}{c}\text { Акт № } 65 \text { от } \\
28.10 . \\
1985 \text { г. } \\
\end{array}$ & $\begin{array}{l}\text { Белка-летяга (Pteromys } \\
\text { volans) - отряд грызуны, ce- } \\
\text { мейство беличьи. }\end{array}$ & 2 \\
\hline 79 & $9218 / 12$ & $\begin{array}{c}\text { Акт №5 от } \\
12.03 .1986 \text { г. }\end{array}$ & $\begin{array}{l}\text { Ежик (Erinaceus europaeus) - } \\
\text { отряд насекомоядные, семей- } \\
\text { ство ежовые. }\end{array}$ & 1 \\
\hline 80 & $9419 / 1$ & $\begin{array}{c}\text { Акт № } 117 \text { от } \\
24.11 . \\
1987 \text { г. }\end{array}$ & $\begin{array}{l}\text { Куница (Martes) - отряд хищ- } \\
\text { ные, семейство куньи. }\end{array}$ & 1 \\
\hline $\begin{array}{l}81- \\
82\end{array}$ & $9419 / 2-3$ & & $\begin{array}{l}\text { Норка (Mustela lutreola) - от- } \\
\text { ряд хищные, семейство ку- } \\
\text { ньи. }\end{array}$ & 2 \\
\hline 83 & 9438 & & $\begin{array}{l}\text { Белка (Sciurus) - отряд гры- } \\
\text { зуны, семейство беличьи. }\end{array}$ & 1 \\
\hline 84 & $10388 / 2$ & $\begin{array}{l}\text { Акт № } 12 \text { от } \\
01.02 .1996 \text { г }\end{array}$ & $\begin{array}{l}\text { Корсак (Vulpes corsac) - от- } \\
\text { ряд хищные, семейство псо- } \\
\text { вые. }\end{array}$ & 1 \\
\hline 85 & $10388 / 3$ & & $\begin{array}{l}\text { Барсук (Meles meles) - отряд } \\
\text { грызуны, семейство куньи. }\end{array}$ & 1 \\
\hline 86 & $10388 / 6$ & & $\begin{array}{l}\text { Горностай (Mustela erminea) } \\
\text { - отряд хищные, семейство } \\
\text { куньи. }\end{array}$ & 1 \\
\hline 87 & $10503 / 1$ & $\begin{array}{l}\text { Акт № } 26 \text { от } \\
06.09 .1999 \text { г }\end{array}$ & $\begin{array}{l}\text { Манул (Otocolobus manul) - } \\
\text { отряд хищные, семейство ко- } \\
\text { шачьи. }\end{array}$ & 1 \\
\hline 88 & $10503 / 2$ & & $\begin{array}{l}\text { Тарбаган-Сурок (Marmota) - } \\
\text { отряд грызуны, семейство бе- } \\
\text { личьи. }\end{array}$ & 1 \\
\hline 89 & $10503 / 3$ & & $\begin{array}{l}\text { Заяц-тоолай (Lepus tolai) - } \\
\text { отряд зайцеобразные, семей- } \\
\text { ство зайцевые. }\end{array}$ & 1 \\
\hline 90 & $10503 / 4$ & & $\begin{array}{l}\text { Корсак (Vulpes corsac) -отряд } \\
\text { хищные, семейство псовые. }\end{array}$ & 1 \\
\hline 91 & HB 466 & $\begin{array}{l}\text { Акт № } 65 \text { от } \\
28.05 .1985 \text { г }\end{array}$ & $\begin{array}{l}\text { Белка-летяга (Pteromys } \\
\text { volans) - отряд грызуны, ce- } \\
\text { мейство беличьи. }\end{array}$ & 1 \\
\hline $\begin{array}{c}92- \\
93\end{array}$ & $\begin{array}{c}\mathrm{HB} \\
610 / 1-2 \\
\end{array}$ & $\begin{array}{l}\text { Акт № } 153 \\
\text { от12.09.1988г }\end{array}$ & $\begin{array}{l}\text { Заяц (Lepus) - отряд зайцеоб- } \\
\text { разные, семейство зайцевые. }\end{array}$ & 2 \\
\hline 94 & $\begin{array}{c}\mathrm{HB} \\
623 / 1\end{array}$ & $\begin{array}{c}\text { Акт № } 9 \text { от } \\
15.02 .1989 \text { г }\end{array}$ & $\begin{array}{l}\text { Рысь (Lynx lynx) - отряд } \\
\text { хищные, семейство кошачьи. }\end{array}$ & 1 \\
\hline 95 & $\begin{array}{c}\mathrm{HB} \\
623 / 3 \\
\end{array}$ & & $\begin{array}{l}\text { Заяц (Lepus) - отряд зайцеоб- } \\
\text { разные, семейство зайцевые. }\end{array}$ & 1 \\
\hline $\begin{array}{c}96- \\
98 \\
\end{array}$ & $\begin{array}{c}\mathrm{HB} \\
623 / 4-6 \\
\end{array}$ & & $\begin{array}{l}\text { Заяц (Lepus) - отряд зайцеоб- } \\
\text { разные, семейство зайцевые. }\end{array}$ & 3 \\
\hline $\begin{array}{l}99- \\
100\end{array}$ & $\begin{array}{c}\mathrm{HB} \\
683 / 1-2\end{array}$ & $\begin{array}{c}\text { Акт № } 133 \text { от } \\
05.10 .1989 \text { г. }\end{array}$ & $\begin{array}{l}\text { Тушканчик (Dipodidae) - от- } \\
\text { ряд грызуны, семейство туш- } \\
\text { канчиковые. }\end{array}$ & 2 \\
\hline
\end{tabular}




\begin{tabular}{|c|c|c|c|c|}
\hline $\begin{array}{l}101- \\
102\end{array}$ & $\begin{array}{c}\mathrm{HB} \\
683 / 3-4\end{array}$ & & $\begin{array}{l}\text { Землеройка (Soricidae) - от- } \\
\text { ряд насекомоядные, семейст- } \\
\text { во млекопитающих. }\end{array}$ & 2 \\
\hline 103 & $\begin{array}{c}\mathrm{HB} \\
683 / 5\end{array}$ & & $\begin{array}{l}\text { Мышь серая (Mus musculus) - } \\
\text { отряд грызуны, семейство } \\
\text { мышиные. }\end{array}$ & 1 \\
\hline 104 & $\begin{array}{c}\mathrm{HB} \\
683 / 6\end{array}$ & & $\begin{array}{l}\text { Ласка (Mustela nivalis) - от- } \\
\text { ряд хищные, семейство ку- } \\
\text { ньи. }\end{array}$ & 1 \\
\hline 105 & $\begin{array}{c}\mathrm{HB} \\
684 / 1\end{array}$ & $\begin{array}{l}\text { Акт № } 134 \text { от } \\
05.10 .1989 \text { г }\end{array}$ & $\begin{array}{l}\text { Бурундук (Tamias sibiricus) - } \\
\text { отряд грызуны, семейство бе- } \\
\text { личьи. }\end{array}$ & 1 \\
\hline 106 & $\begin{array}{l}\mathrm{HB} \\
867 / 1\end{array}$ & $\begin{array}{lll}\text { Акт № } 33 & \text { от } \\
26.04 .1994 & \text { г }\end{array}$ & $\begin{array}{l}\text { Белка (Sciurus) - отряд гры- } \\
\text { зуны, семейство беличьи. }\end{array}$ & 1 \\
\hline 107 & $\begin{array}{l}\mathrm{HB} \\
867 / 2\end{array}$ & & $\begin{array}{l}\text { Горностай (Mustela erminea) } \\
\text { - отряд хищные, семейство } \\
\text { куньи. }\end{array}$ & 1 \\
\hline 108 & $\begin{array}{c}\mathrm{HB} \\
867 / 3\end{array}$ & & $\begin{array}{l}\text { Соболь (Martes zibellina) - } \\
\text { отряд хищные, семейство ку- } \\
\text { ньи. }\end{array}$ & 1 \\
\hline $\begin{array}{c}109- \\
110\end{array}$ & $\begin{array}{c}\text { HB } \\
886 / 1-2\end{array}$ & $\begin{array}{l}\text { Акт № } 15 \text { от } \\
23.03 .1995 \text { г }\end{array}$ & $\begin{array}{l}\text { Белка (Sciurus) - отряд гры- } \\
\text { зуны, семейство беличьи. }\end{array}$ & 2 \\
\hline 111 & $\begin{array}{c}\mathrm{HB} \\
886 / 10\end{array}$ & & $\begin{array}{l}\text { Бурундук (Tamias sibiricus) - } \\
\text { отряд грызуны, семейство бе- } \\
\text { личьи. }\end{array}$ & 1 \\
\hline 112 & HB 952 & $\begin{array}{l}\text { Акт №12 от } \\
01.02 .1996 \text { г } \\
\end{array}$ & $\begin{array}{l}\text { Белка (Sciurus) - отряд гры- } \\
\text { зуны, семейство беличьи. }\end{array}$ & 1 \\
\hline 113 & $\begin{array}{c}\mathrm{HB} \\
958 / 2\end{array}$ & & $\begin{array}{l}\text { Колонок (Mustela sibirica) - } \\
\text { отряд хищные, семейство ку- } \\
\text { ньи. }\end{array}$ & 1 \\
\hline 114 & $\begin{array}{c}\mathrm{HB} \\
997 / 7\end{array}$ & $\begin{array}{l}\text { Акт № } 43 \text { от } \\
26.11 .1997 \text { г }\end{array}$ & $\begin{array}{l}\text { Колонок (Mustela sibirica) - } \\
\text { отряд хищные, семейство ку- } \\
\text { ньи. }\end{array}$ & 1 \\
\hline 115 & HB 1194 & $\begin{array}{l}\text { Акт № } 31 \text { от } \\
23.02 .2002 \text { г }\end{array}$ & $\begin{array}{l}\text { Кабарга (Moschus } \\
\text { moschiferus) - отряд Парно- } \\
\text { копытные, семейство кабар- } \\
\text { говые. }\end{array}$ & 1 \\
\hline 116 & $\begin{array}{c}\mathrm{HB} \\
1265\end{array}$ & $\begin{array}{l}\text { Акт № } 25 \text { от } \\
12.03 .2003 \text { г }\end{array}$ & $\begin{array}{l}\text { Норка (Mustela lutreola) - от- } \\
\text { ряд хищные, семейство ку- } \\
\text { ньи. }\end{array}$ & 1 \\
\hline 117 & $\begin{array}{c}\mathrm{HB} \\
1278 / 1\end{array}$ & $\begin{array}{l}\text { Акт № } 41 \text { от } \\
29.04 .2003 \text { г }\end{array}$ & $\begin{array}{l}\text { Заяц (Lepus) - отряд зайцеоб- } \\
\text { разные, семейство зайцевые. }\end{array}$ & 1 \\
\hline 118 & $\begin{array}{c}\mathrm{HB} \\
1278 / 2\end{array}$ & & $\begin{array}{l}\text { Белка (Sciurus) - отряд гры- } \\
\text { зуны, семейство беличьи. }\end{array}$ & 1 \\
\hline 119 & $\begin{array}{c}\mathrm{HB} \\
1288\end{array}$ & $\begin{array}{l}\text { Акт № } 58 \text { от } \\
24.07 .2003 \text { г }\end{array}$ & $\begin{array}{l}\text { Соболь (Martes zibellina)- } \\
\text { отряд хищные, семейство ку- } \\
\text { ньи. }\end{array}$ & 1 \\
\hline 120 & $\begin{array}{l}\mathrm{HB} \\
1302\end{array}$ & $\begin{array}{l}\text { Акт № } 84 \text { от } \\
08.09 .2003 \text { г }\end{array}$ & $\begin{array}{l}\text { Норка (Mustela lutreola) - от- } \\
\text { ряд хищные, семейство ку- } \\
\text { ньи. }\end{array}$ & 1 \\
\hline 121 & $\begin{array}{c}\mathrm{HB} \\
1341 / 3\end{array}$ & $\begin{array}{l}\text { Акт № } 3 \text { от } \\
20.01 .2004 \text { г }\end{array}$ & $\begin{array}{l}\text { Белка (Sciurus) - отряд гры- } \\
\text { зуны, семейство беличьи. }\end{array}$ & 1 \\
\hline
\end{tabular}




\begin{tabular}{|c|c|l|l|l|c|}
\hline 122 & $\begin{array}{c}\text { HВ } \\
1342 / 1\end{array}$ & & $\begin{array}{c}\text { Акт № 4 от } \\
26.01 .2004 \text { г }\end{array}$ & $\begin{array}{l}\text { Белка (Sciurus) - отряд гры- } \\
\text { зуны, семейство беличьи. }\end{array}$ & 1 \\
\hline 123 & HВ & & Акт № 42 от & Заяц (Lepus) - отряд зайцеоб- & 1 \\
& $1368 / 1$ & & 07.06 .2004 г & разные, семейство зайцевые. & \\
\hline 124 & HB & & Акт № 95 от & Крот (Talpidae) - отряд насе- & 1 \\
& 1533 & & 12.10 .2005 г & $\begin{array}{l}\text { комоядные, семейство крото- } \\
\text { вые. }\end{array}$ & \\
& & & Акт № 39 от & Тушка млекопитающих & 98 \\
\hline $125-$ & НВ & & 28.07 .2006 г & & \\
222 & 1654 & & & &
\end{tabular}

По инвентарной книге отдела фондов отмечено, что из всех имеющихся в коллекции предметов 85 ед. описаны, не описаны - 152 ед. Это означает, что менее половины экспонатов (44 \%) не прошли научную инвентаризацию, научные паспорта на них не составлены, что определяет задачи дальнейшей работы.

Проведенный количественный и качественный обзор коллекции будет полезен для составления планов по дальнейшему комплектованию и каталогизации фондовых материалов. Также значительная часть мелких млекопитающих рекомендована для активного использования в экспозиционной работе, что должно способствовать существенному повышению наглядности экспозиции и достоверности представленных в ней научных данных. В настоящее время, в связи с нехваткой экспозиционных площадей Национального музея, показана лишь малая часть млекопитающих в разделе «Природные зоны Тувы» постоянной экспозиции «Тыва - жемчужина Центра Азии» в зале № 1 (2 этаж), в разделе «Таежные экосистемы» и «Сезонные изменения в природе» постоянной экспозиции «Тайга: в единстве с природой» в зале № 7 (2 этаж) и постоянной экспозиции «Степные экосистемы Тувы. Природопользование в степи» в зале № 2 (2 этаж).

Для популяризации и сохранения историко-культурного и природного наследия сотрудниками тувинского музея используются разные формы научно-просветительной работы - тематические экскурсии, беседы, лекции, выездные формы выставок. Аудиторией выступает самый широкий круг населения - дети, молодежь и люди старшего поколения. Также сотрудниками активно ведется работа по информационному освещению деятельности музея в сети Интернет. Ведется активная интеграция как экологического, так и гуманитарного и культурно-эстетического направлений в образовательной деятельности музея. Также приоритетной задачей для Национального музея Республики Тыва должна стать большая работа по вводу в научный оборот коллекций через публикацию каталогов, альбомов, путеводителей, написание научных работ с целью популяризации объектов наследия среди молодого поколения. 


\section{Примечания}

1. Аракчаа Л.К. Истоки экологического воспитания. Кызыл, 2004.

2. Банников А. Г. Млекопитающие Монгольской народной республики. - М.: АН СССР, 1954. - 669 с. М.: 1998.

3. Динец В., Ротшильд Е. Энциклопедия природы России. Звери. -

4. Животный мир Енисейской равнины / Савченко А.П., Сидоркин В.Н., Беляков А.В.. Том 1. - Красноярск, 2001.

5. Наумов Н.П. Типы поселений грызунов и их экологическое значение// Зоологический журнал. - 1954.- Т. 33. №2. - С. 268-275.

6. Наумов Н.П. Структура популяций и динамика численности наземных позвоночных // Зоологический журнал. - 1967. - Т. 46, №10. - С. $1470-1486$.

7. Наумов Н.П. Биологические (сигнальные) поля и их значение в жизни млекопитающих // Успехи современной териологии / Под ред. В.Е. Соколова. - М.: Наука, 1977. - С. 93-110.

8. Охотничье-промысловые животные Западной Сибири, их охрана и воспроизводство / А.М. Адам, 3.В. Гайдуенко, Е.М. Гришина и др. ; Ред. к. б. н., доц. А.М. Гынгазов. - Томск : Изд-во Том. ун-та, 1979. - 90 с.

9. Красная книга РСФСР. М., 1983. 423 с.

10. Кузякин А. П. Зоогеография СССР // Учен. зап. Моск. обл. пед. ин-та им. Н.К. Крупской, 1962. Т. 109: Биогеография, вып. 1. С. 3-182.

\section{References}

1. Arakchaa L.K. Istoki ekologicheskogo vospitanija. [The sources of environmental education]. Kyzyl, 2004. [In Russ.]

2. Bannikov A. G. Mlekopitayushchije Mongol'skoj narodnoj respubliki [The mammals of the Mongolian People's Republic]. - M., 1954. 669 p. [In Russ.]

3. Dinets V., Rotshild E. Enciklopedija prirody Rossi. Zveri [The nature encyclopedia of Russia. Animals] - M., 1998. [In Russ.]

4. Zhivotnyj mir Ejnisejskoj ravniny / Savchenko A.P., Sidorkin V.N., Belyakov A.V. Tom 1.- Krasnoyarsk, 2001. [In Russ.]

5. Naumov N. P. Tipy poselenij gryzunov i ikh ekologicheskoje znachenije [Types of rodent settlements and their ecological significance] // Zoologicheskij zhurnal [Zoological journal].- 1954. - Vol. 33, № 2. Pp. 268275. [In Russ.]

6. Naumov N. P. Struktura populyacij i dinamika chislennosti nazemnyh pozvonochnykh [Population structure and dynamics of the number of terrestrial vertebrates] // Zoologicheskij zhurnal [Zoological journal]. -1967. -Vol. 46, № 10. Pp. 1470-1486. [In Russ.]

7. Naumov N. P. Biologicheskie (signal'nye) polya i ikh znachenie $v$ zhizni mlekopitayushchikh [Biological fields and their importance in the life of mammals] // Uspekhi sovremennoj teriologii [Success of modern theriology] / Ed. V. E. Sokolova. -M., 1977. Pp. 93-110. [In Russ.] 
8. Okhotnich'je-promyslovye zhivotnye Zapadnoj Sibiri, ikh okhrana i vosproizvodstvo [Hunting animals of Western Siberia, their protection and reproduction] / A.M. Adam, Z.V. Gaiduenko, E.M. Grishina [et al]; ed. by Ph.D. in Biology, assoc. prof. A.M. Gyngazov. - Tomsk, 1979. - 90 p. [In Russ.]

9. Krasnaya kniga RSFSR. [The red book of the RSFSR]. M., 1983. 423 p. [In Russ.]

10. Kuzyakin A. P. Zoogeografija SSSR [Zoogeography of the USSR] // Uchen. zap. Mosk. obl. ped. in-ta im. N. K. Krupskoj [Memoirs of the Moscow reg. ped. Institute named after N.K. Krupskaya].1962. Vol. 109: Biogeography, № 1. Pp. 3-182. [In Russ.]. 
DOI 10.31443/2541-8874-2019-2-10-79-88

УДК 069(571.52-4)

Монгуш Ш.Х.

Mongush Sh.Kh.

ТУВИНСКИЕ ПОДУШКИ В СОБРАНИИ НАЦИОНАЛЬНОГО

МУЗЕЯ ИМ. АЛДАН-МААДЫР РЕСПУБЛИКИ ТЫВА

\section{TUVAN PILLOWS IN THE COLLECTION OF THE NATIONAL MUSEUM OF THE TUVA REPUBLIC NAMED AFTER ALDAN- MAADYR}

В статье рассказывается о коллекции тувинских подушек, хранящихся в фондах Национального музея им. Алдан-Маадыр Республики Тыва.

Даны научное описание и информация о комплектовании коллекций тувинских подушек в фондах этнографии «Ткань. Кожа», также рассматривается их связь и значение с тувинской национальной традицией. По ходу изучения коллекции выявлены и описаны отличия подушек по материалу и технике изготовления.

Важнейшими источниками для рассмотрения данного материала являются научные труды исследователей Тувы, музейные материалы, воспоминания информантов.

В заключение статьи сделаны выводы о значимости коллекции тувинских подушек как уникальной части историко-культурного наследия Тувы и о ее значении как источника для дальнейшего изучения материальной культуры Тувы первой половины XX века.

The article describes the collection of the Tuvan pillows stored in the funds of the National Museum of the Tuva Republic named after AldanMaadyr.

The scientific description and information about the collections of the Tuvan pillows compiling in the funds of ethnography "Fabric. Leather" are given, their importance and connection with the Tuvan national tradition are considered. In the course of studying the collection the differences in material and manufacturing techniques are identified and described.

The most important sources for considering such a material are the scientific works of the Tuvan researchers, museum materials and informants' memories.

In conclusion, the author draws conclusions about the importance of the Tuvan pillows collection as a unique part of the historical and cultural heritage of Tuva and its significance for the further study of the material culture of Tuva in the first half of the $\mathrm{XX}^{\text {th }}$ century. 
Ключевые слова: Национальный музей Республики Тыва, коллекция подушек, этнографический фонд музея, лицевая часть тувинской подушки, материальная культура

Keywords: National Museum of the Republic of Tuva, collection of pillows, ethnographic fund of the museum, front part of the Tuvan pillow, material culture.

Подушка - постельная принадлежность в виде зашитого со всех сторон мешка, набитого мягким материалом. Само слово «подушка» произошло от русского слова «под ухо». Служит для опоры головы лежащего человека, для удобства сидения на диване или для декоративных целей [1, c. 703]. Различают разные виды подушек по назначению: ночные (для сна), декоративные (для украшения интерьера), подушки безопасности (в автомобиле), ортопедические и т.д.

История подушек на территории нынешней Тувы уходит в глубь веков. В первую очередь, это проявляется в погребальной обрядности народов Сибири.

В скифских захоронениях распространен ритуал помещения под голову умершего седла, уложенного наподобие подушки. Следует отметить, что седло играло важную роль в культуре скотоводческих народов и являлось обязательным атрибутом сопроводительного инвентаря.

Именно для этого периода в Туве археологи зафиксировали размещение черепов, погребенных на плоских камнях или плитках, иногда обложенных травой.

Позднее в хуннских и средневековых погребениях Тувы каменные «подушки» отмечаются уже эпизодически [2, с. 296].

В фондах Национального музея Республики Тыва сосредоточены ценнейшие, порой уникальные, свидетельства материальной и духовной культуры населения, проживающего на территории Тувы на протяжении многих веков. Важнейшее место в них занимает коллекция, представляющая быт и традиционную культуру тувинцев. Начало ей положено в 30 -е годы XX века, когда представители РСТК, члены партийной организации ТНР и назначенный на заседании Политбюро ЦК ТНРП первый директор тувинского музея В.П. Ермолаев организовали сбор экспонатов для будущего музея во всех кожуунах и населенных пунктах, а также на чабанских стоянках республики. Наиболее активно она комплектовалась в 6070-е годы прошлого столетия, приобрела широту и системность, пополнилась сотнями музейных вещей.

Сегодня значительную часть этнографического фонда «Ткань. Кожа» составляют изделия из меха - зимняя (и летняя) женская и мужская одежда, обувь, головные уборы, сумки, подушки, конская упряжь, всего около 13350 единиц хранения музейных предметов. Хронологические рамки коллекции: середина XIX - конец XX вв. 
Одной из самой уникальной коллекцией фонда этнографии является коллекция тувинских подушек, которая представляет культурную ценность музея и свидетельствует о мастерстве тувинских мастериц.

В коллекции подушек музея собрано около 23 единиц разных видов и размеров, из них 16 единиц является тувинскими национальными подушками, сделанными местными мастерами, представляющими несколько районов Тувы, также г. Кызыл. Сбор коллекции датируется 19572018 гг. Фонды музея и в особенности этнографическая коллекция пополнялись на протяжении всей его истории, благодаря деятельности ветеранов музея: М.Б. Кенин-Лопсана, Е.Ш. Байкара, К.Ш. Монгуш, Т.С. Нурзат, С.С. Баян-оол и др.

Первое поступление коллекции тувинских подушек в фонды музея зафиксировано в книге поступлений сектора учета музея в 1957 г. Запись сделана от 26.07.1957 г. Скаковой Т.М. Подушка приобретена сотрудниками музея во время командировки в Улуг-Хемский и Чаа-Хольский районы.

Коллекцию тувинских подушек в фондах тувинского музея разделили на три группы, это три периода поступления коллекции:

I. Подушки, поступившие в 1950-1960-е гг.

II. Подушки, поступившие в 1970-1990-е гг.

III. Подушки, поступившие в 2003-2018-е гг.

Подушки из первой группы отличаются от последующих подушек из коллекции техникой изготовления, материалом и сохранностью. Все они покрыты хлопчатобумажной тканью, есть подушки, использующие в основе войлок ручного валяния и очень простого декора с помощью комбинирования разноцветных тканей без вышитых пуговиц и тесьмы. Шелк пришивали только на лицевую часть или для комбинирования.

Одним из интересных материалов, присутствующих в декоре этих подушек, это самодельные маленькие белые пуговицы-тана, изготовленные из морских ракушек местными мастерами. Привозили морские ракушки из Китая, Индии. Приобретали их также как и большинство товаров, путем обмена на скот, пушнину у приезжих купцов и торговцев. Украшения пуговицами тана встречаются только на тувинских подушках, в национальных головных уборах и на свадебных нарядах. Также в декоре подушки первой группы использованы бляшки, которые являются украшением подушек более раннего периода. 


\section{I. Подушки, поступившие в 1950-1960-е гг.}

1. Самое первое поступление, как мы ранее

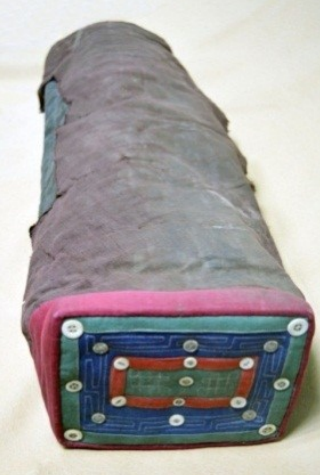
писали, это подушка КП 2722 из Улуг-Хемского района, поступила в музей в 1957 г., сбор музейного сотрудника Т. М. Скаковой [3].

Из-за долгого бытования сохранность данной подушки очень плохая, загрязненная поверхность и порванные места, узор на лицевой части небогатый, ограничен только тремя рядами четырехугольных поясков разных цветов, украшена всего двадцатью пришитыми пуговицами белого цвета разных размеров. Несмотря на это, лицевую часть этого экземпляра дополняют вышивки, простроченные белой ниткой на швейной машинке, чего нет на других подушках. Это геометрический меандр, пришитый на синем фоне. А по центру на голубом фоне также белыми нитками с двух сторон прострочен узор «узел счастья» (по тув. олчей удазыны). Узор «узел счастья» один из излюбленных узоров у тувинцев, его можно увидеть везде: на предметах быта, на одежде, на посудах и на заборах и т. д. Многие знаки и узоры появились в Туве вместе с буддизмом в XIII веке. Узел счастья это один из восьми знаков буддизма, который символизирует бесконечность и долговечность жизни.

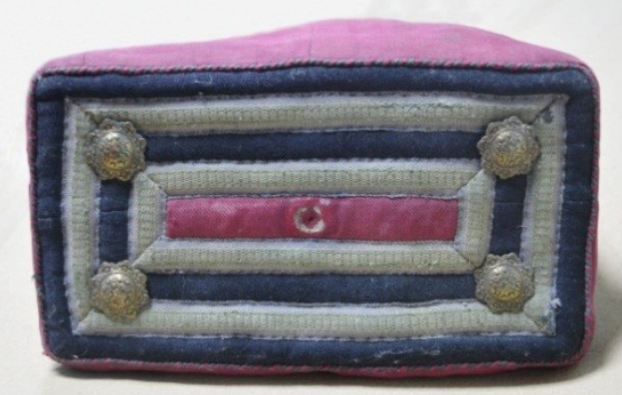

2. ТРКМ инв. 165 [4].

Подушка очень необычная, не похожая на большинство тувинских подушек из коллекции музея. Основа подушки сшита из выделанной шкуры теленка с коричневым мехом, сверху покрыта хлопчатобумажной тканью талемба желтого цвета. Края лицевой, задней зауженной стороны и вдоль длины нижней стороны комбинированы тканью малинового цвета. Внутри лицевой стороны подушки вставлена и зашита прямоугольная дощечка, для придания плоской формы. На черном фоне лицевой стороны по самому краю пришита веревочка из закрученных ниток двух цветов, черной и малиновой. Далее пришиты два пояска прямоугольной формы из широкой голубой тесьмы. По центру внутреннего пояска пришита аппликация из ткани малинового цвета. Украшена она по четырем углам маленькими бляшками в форме восьмилепестковых цветов из желтого металла. Пятая центральная бляшка утеряна, остался только след. Зауженная задняя сторона овальной формы украшена точечными стежками из черной нитки ручного шитья.

Изучив данную подушку, мы обнаруживаем ее сходство с описанием тувинских подушек более раннего периода, который описывает С.И. Вайнштейн в своей книге «Мир кочевников Центра Азии»»». Эта подушка 


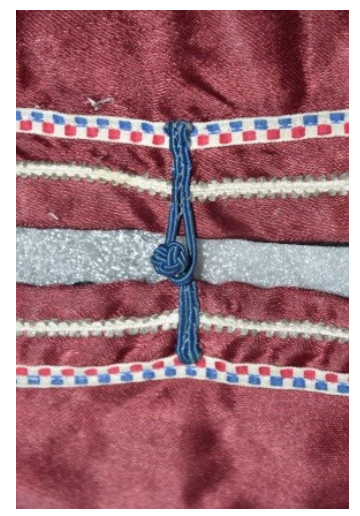

сшита из выделанной ручным способом шкуры теленка, лицевая сторона украшена металлическими бляшками. Нет ни одной подушки среди коллекции тувинских подушек музея, сшитой из шкуры и украшенной металлическими бляшками. Учитывая использованные материалы для шитья данной подушки, можно сказать о состоятельности хозяина, так как простой арат (крестьянин) не стал бы тратить выделанную шкуру на подушку, а не на одежду и заказывать кузнецу такие недешевые бронзовые бляшки. Также, несмотря на отсутствие информации, отнесли ее в первую группу подушек из-за сходства ранними видами тувинских подушек по материалу и декору.

Во вторую группу включили шесть подушек из коллекции, поступившие в 1970-1990-ые гг., изготовленные и бытовавшие в разгар развития торгово-промышленной индустрии советского периода. Оформлены они очень богато. Отличаются они от предыдущей группы подушек из коллекции техникой шитья - машинная, богатым разнообразием используемых материалов и декора. Использованы такие материалы, как китайский шелк, бархат, плюш, богатое разнообразие тесьмы, большое количество уже заводских пуговиц разного размера и цвета. Оформлены они более свободной авторской фантазией, придерживающей традиционную технологию. Улучшилась сохранность.

II. Подушки, поступившие в 1970-1980-е гг.

1. КП 7247 поступила в музей в 1971 г. [5]. Это одна из богато украшенных и нарядных экземпляров среди коллекции тувинских подушек. Она покрыта атласной тканью коричневого цвета.

Лицевая сторона подушки украшена девятью плотно пришитыми

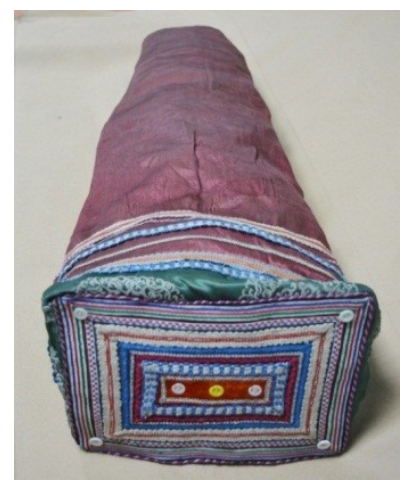
друг к другу разноцветными тесьмами четырехугольной формы. По самому краю ее пришит шнурок из закрученных двух ниток фиолетового и сиреневого цветов. Итого на лицевой стороне подушки девять поясков - кожаа, как обязательный атрибут декора тувинского сундука. По центру пришита плюшевая ткань красного цвета. На ней пришиты три маленькие пуговицы, две белые и одна посередине желтая, также по четырем углам пришиты по одной маленькой белой пуговице. Итого нашиты на лицевой стороне семь пуговиц. Край лицевой части вокруг обшит зеленым шелком шириной 4 см и на ширине 12 см от лицевой части она украшена пятью разноцветными тесьмами разной ширины.

На нижней стороне пришита полоска из зеленого шелка длиной 25 см от края, откуда сделан разрез, который обшит вокруг двумя рядами тесьмы и застегнут на пуговице - дошка, плетенной из тесьмы синего цвета с петлей. Внутри подушка полая, не наполнена, обшита полностью 
тканью черного цвета. Зауженный другой конец подушки овальной формы, украшен пришитыми тесьмами в виде решетки.

Плетеную пуговицу дошка тувинские мастерицы вплетали сами из самодельной круглой веревки, сшитой из шелка или ткани, когда не было возможности заказать кузнецам тувинские серебряные или бронзовые круглые пуговицы на ножках. Поэтому мы их видим в основном на на-

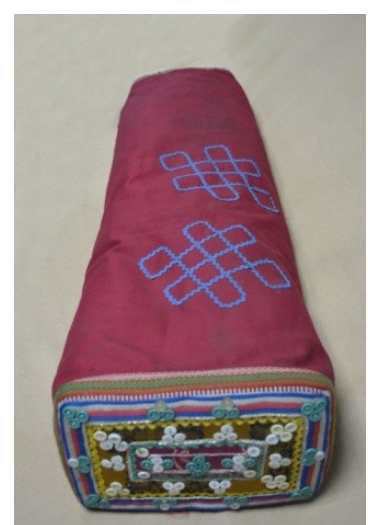
циональной одежде, на безрукавках. Также дошка без петли для пуговицы как обязательный атрибут национального головного убора пришивалась на верхушке тувинских шапок. Дошка на подушке, случай единичный среди предметов коллекции музея и даже среди работ современных мастериц. По традиционной технологии шитья тувинских подушек на внутренних разрезах пришивали завязки из ткани. Мы видим в данном предмете широкую фантазию мастера, богатый декор работы и уникальность.

2. КП $9341 / 5$ поступила в музей в 1987 г. от

Адам И.Ч. п. Бай-Тал [6].

Национальная подушка, покрытая хлопчатбумажной тканью $m a$ лемба бордового цвета, закуплена фондово-закупочной комиссией музея за пятьдесят рублей. Внутри лицевой стороны подушки вставлена и зашита прямоугольная дощечка, для придания плоской формы.

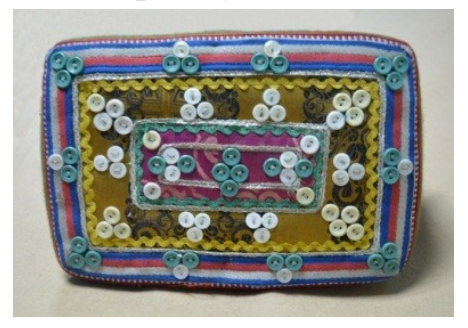

На лицевой стороне подушки пришиты аппликации из двух цветов шелка желтого и малинового по центру. Обрамлена она по краю, и середине по три ряда поясков прямоугольной формы. На нем пришиты белые и зеленые пуговицы маленького размера в виде треугольников и ромбиков. Всего пришито пуговиц на по-

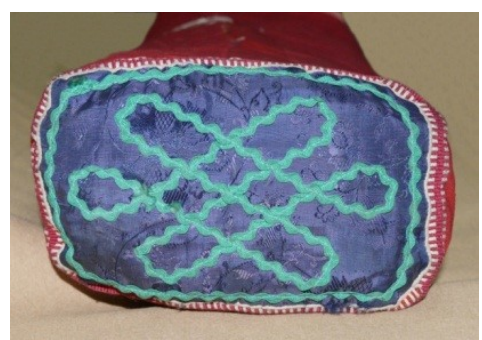
душке семьдесят девять.

На зауженной узкой стороне она комбинирована шелком синего цвета и украшена узором олчей удазыны из волнистой тесьмы бирюзового цвета. Внутри подушка полая, не наполнена, обшита тканью пестрого цвета. На верхней стороне подушки волнистой тесьмой синего цвета пришиты два узора олчей удазыны. Подушка КП 9341/5 богато декорирована с задних и верхних сторон.

Третья группа состоит из пяти подушек, поступивших в фонды музея в 2003-2018 гг. Отличаются они от предыдущих групп коллекции новизной оформления декора, ручной вышивкой узоров, вышивкой бисером, использованием более дорогих материалов, таких как парча, шелк. Например, если раньше национальный шелк могли использовать только на аппликацию, то здесь подушка шелком покрыта полностью. Раньше 
лицевую часть подушки украшали в основном тесьмой и самодельными пуговицами тана или простыми заводскими белыми пуговицами, то здесь появились бисер, бусы и обилие цветных ниток для современной ручной вышивки. Хорошая сохранность.

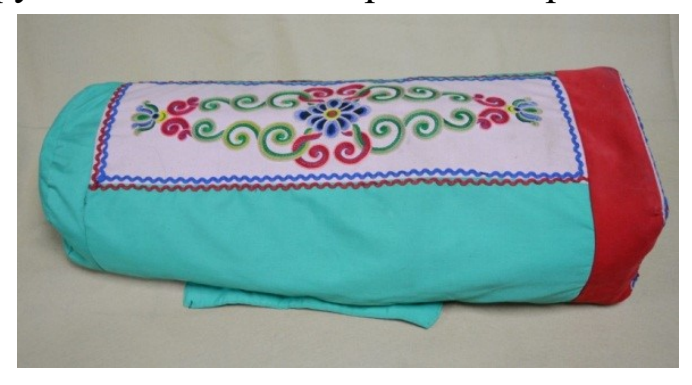

III. Подушки, поступившие в 2003-2018 гг.

КП 10739/3 поступила в музей в 2003 г., автор Тас-оол Раиса Копеековна, мастерица из Бай-Тайгинского района [7]. Тыва сыртык - национальная подушка, покрытая тканью светло-зеленого цвета, края лицевой стороны красного цвета шириной 6,8 см.

Общий фон лицевой стороны и

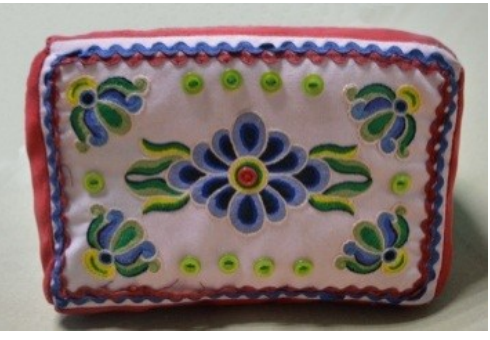
вставка на верхней части из ткани розового цвета вышиты цветочными узорами. Края их обрамлены одинаковой волнистой тесьмой красного и синего цветов. Вышивку лицевой стороны подушки дополняют пришитые маленькие зеленые пуговицы, по четыре штуки сверху и снизу, и по одному справа и слева, а посередине цветка пришита одна красная пуговица. Всего на лицевой части подушки пришито одиннадцать пуговиц. На нижней стороне сделан разрез с клапаном, который застегивается на трех пуговицах. Внутри белый войлок ручного валяния. Дизайн декора состоит уже из современных узоров, общий вид и основа традиционной подушки сохранена.

В таком порядке хранится коллекция тувинских подушек Национального музея Республики Тыва, представляя историю и современное состояние прикладного искусства Тувы, участвуя в различных стационарных, передвижных и выездных выставках по республике и за ее пределами.

Каждая из них уникальна, так как сделана в единственном экземпляре и представляет большую историко-культурную и художественную ценность.

Из воспоминаний информаторов мы можем дополнить следующее. Изучая коллекцию тувинских подушек, мы часто задаемся вопросом, почему они в основном все полые, чем их наполняли тувинцы. Информатор Ооржак Д.К-Х.: «Да, я помню подушку своей матери, она была заполнена лоскутками от выделанных шкур чурук, прятала она туда свою мизерную зарплату, составляющую 1, 2 рубля. Еще там находилась ее игольница и нитки, скрученные из сухожилий, расческа и какие-то украшения».

Шивит-Хуурак Ч.Х.: «Мы очень любили ходить с братом в гости к бабушке, она достанет из своей тувинской подушки мешочек и оттуда нам раздает кусочки каменного сахара». 
Сюрюн С.С.: «Да, в юрте моих родителей были тувинские подушки, но чем они были наполнены, не знаю, не видела. У меня в детстве постоянно были проблемы с глазами, мама находила среди своих пуговиц ту самую пуговицу, что сделана из ракушки, проскабливала лезвием ножа и лечила мне глаза».

Монгуш В.С.: «Я видел в юрте бабушки тувинскую подушку, красиво украшенную маленькими пуговицами тана, сделанными местными мастерами из ракушек курm xabbl. А что внутри - не знаю, не разрешали трогать подушку детям».

Майны Б.С.: «Я видел тувинские подушки у родственников, красивые такие с пуговицами и с разноцветными поясками - кожаа как на сундуках, а что внутри - не знаю, видно, детям не разрешали их трогать».

Исходя из этого, мы можем сделать следующие выводы: понятие подушка для тувинца довольно обширное. В первую очередь, конечно, у очевидцев вырисовывается красиво вышитая подушка с лицевой стороны, которая аккуратно сложена у изголовья единственной деревянной кровати, которая стоит на правой женской стороне юрты. Во-вторых, это та шкатулка матери или бабушки, где она хранит самые ценные вещи, втретьих, это священный предмет, на котором спит только мама и никто не имеет право трогать ее.

Подушка - предмет, который хранит покой и придает силу спящему на нем человеку. Также она охраняет дух ребенка, именно у изголовья кровати висит колыбель для детей, которая на душке в маленьких подушечках зашиты пуповины всех детей семьи. Тувинцы всегда гордились количеством детей, несмотря на бедность в семье. В Туве и по сей день уважают и почитают многодетных семей, так как с древних времен богатством и счастьем семьи тувинца являлись дети.

В книге «Традиционная культура тувинцев» М. Б. Кенин-Лопсан поясняет некоторые обряды и традиции тувинцев, связанные с детьми и подушкой. «По тувинскому обычаю праздник подстригания волос ребенка проводился, когда ему исполнялось три года с учетом того, что он был в утробе матери девять месяцев. Фактически в два года. Родители специально обращались к шаману или ламе, чтобы они установили день подстригания волос мальчика или девочки.

Основная цель проведения праздника - наделить ребенка личным имушеством. Мальчика подстригает старший дядя. Когда три года исполнялось девочке, самая старшая тетя ножницами с белым платком на руке подстригала ее волосы. Остриженные волосы хранит мать как священную вещь, в специальном мешочке, спрятав его в свою подушку, пуповину ребенка придавливали козьим сальником (эдир), предварительно сделав дырочку, в которую просовывалась ее верхушка, аккуратно перевязывали. Через три или четыре дня этот кончик отпадает. Его кладут на чистую ткань. Шьется маленькая прямоугольная подушечка, куда вкладывают пуповину и зашивают со всех сторон. 
Ритуал с пуповиной означает пожелание иметь много детей. Маленький мешочек с загнутой пуповиной подвешивается на дужке колыбели. Родила мать один раз - вешается одна подушечка, родила девятерых девять подушечек свисают с дужки» [8, с. 232].

Также о тувинских подушках пишет в своей книге «История народного искусства Тувы» Севьян Израилевич Вайнштейн.

«Вплоть до недавнего времени тувинцы-скотоводы пользовались своеобразной валиковой подушкой (сыртык), которую обычно шили из кожи (реже из ткани). Боковую лицевую сторону таких валиковых подушек делали плоской, зашивая в нее прямоугольную дощечку, которую обтягивали орнаментированной кожей или тканью (20X15 см). Эта подушка, лежавшая в изголовье постели, всегда была обращена украшенной стороной к центру юрты и привлекала внимание. В ней же хранили различные мягкие вещи. Аппликации и тиснения, украшавшие кожаные сыртыки, включали в основном модификации узла, различные завитки, реже меандр. Довольно часто нашивались на сыртыки круглые металлические бляхи, монеты, пуговицы. Декоративные схемы на этих подушках аналогичны расписным орнаментальным композициям на сундуках» [9, c. 88].

\section{Информаторы}

Ооржак Дандар-оол Кок-Хунаевич, 82 года, родился в 1937 г., житель г. Кызыл.

Шивит-Хуурак Чечекмаа Хонук-ооловна, 62 года, родилась в 1956 г., жительница с. Дурген Тандинского кожууна.

Сюрюн Светлана Салчаковна, 73 года, жительница г. Кызыл.

Монгуш Вячеслав Сундуй-оолович, 60 лет, житель г. Чадан.

Майны Биче-оол Салчакович, научный сотрудник отдела краеведения и туризма Национального музея Республики Тыва.

\section{Примечания}

1. Ожегов С. И. Словарь русского языка. М. : Просвещение, 1989.

2. Вайнштейн С. И. Мир кочевников центра Азии. М., 1991.

3. Национальный музей Республики Тыва (НМ РТ). Кн. поступления основного фонда № 1.

4. НМ РТ. Инвентарная книга № 2.

5. НМ РТ. Кн. поступления основного фонда № 7.

6. НМ РТ. Кн. поступления основного фонда № 11.

7. НМ РТ. Кн. поступления основного фонда № 17. 2006.

8. Кенин-Лопсан М. Б. Традиционная культура тувинцев. Кызыл,

9. Вайнштейн С. И. История народного искусства Тувы. М.,1974.

\section{References}

1. Ozhegov S.I. Slovar' [Dictionary]. M., 1989. [In Russ.]. 
2. Vainshtein S.I. Mir kochevnikov centra Azii [The nomads' world of the Center of Asia]. M., 1991. [In Russ.].

3. Nacional'nyj Muzej Respubliki Tyva [The National Museum of the Republic of Tuva (NM RT). The books entries of the main fund \#1. [In Russ.].

4. NM RT. Inventory book № 2. [In Russ.].

5. NM RT. The books entries of the main fund № 7. [In Russ.].

6. NM RT. The books entries of the main fund № 11. [In Russ.].

7. NM RT. The books entries of the main fund № 17. [In Russ.].

8. Kenin-Lopsan M.B. Tradicionnaja kul'tura tuvincev [Traditional culture of the Tuvan people]. Kyzyl, 2006. [In Russ.].

9. Vainshtein S. I. Istorija narodnogo iskusstva Tuvy [History of folk art of Tuva]. M., 1974. [In Russ.].

\section{Informants}

1a. Oorzhak Dandar-ool Kok-Khunaevich, 82 y.o., born in 1937, resident of Kyzyl.

2a. Shivit-Khuurak Chechenmaa Khonuk-oolovna, 62 y.o., born in 1956, villager of Durgen of the Tandinsky kozhuun.

3a. Siuriun Svetlana Salchakovna, 73 y.o., resident of Kyzyl.

4a. Mongush Viacheslav Sundui-oolovich, 60 y.o., resident of Chadan

5a. Mainy Biche-ool Salchakovich, researcher of the Department of Local History and Tourism, National Museum of the Republic of Tuva. 
DOI 10.31443/2541-8874-2019-2-10-89-99

УДК 069:39(571.63)

Свистов Н.Л.

Svistov N.L.

\section{МУЗЕЙНО-ОБРАЗОВАТЕЛЬНЫЙ КОМПЛЕКС «ПАЛЕОДЕРЕВНЯ» КАК ПРИМЕР ИНТЕГРАЦИИ В СОЦИОКУЛЬТУРНОЕ ПРОСТРАНСТВО ЮГА ДАЛЬНЕГО ВОСТОКА}

\section{MUSEUM-EDUCATIONAL COMPLEX «PALEODEREVNYA»AS AN EXAMPLE OF INTEGRATION INTO THE SOCIO-CULTURAL SPACE OF THE FAR EAST SOUTH}

«Палеодеревня» - это музейно-образовательный комплекс, образованный в 2006 г. на базе детского археологического лагеря. Создан в формате музея под открытым небом, где главными экспонатами являются реконструкции жилищ различных временных эпох. Комплекс располагается на территории Партизанского района Приморского края.

На базе комплекса круглый год проводятся интерактивные образовательные программы. Отдельно стоит отметить событийные мероприятия комплекса. Наиболее яркие и посещаемые - это этнические праздники - «Масленица» и «Иван Купала». В отличие от образовательных программ, эти мероприятия вызывают наибольший интерес у одиночного посетителя.

Сейчас наблюдается стабильный поток посетителей, что говорит о сформированном запросе общества и о включенности комплекса в социокультурное пространство региона.

«Paleoderevnya» is a museum-educational complex established on the basis of the children's archeological camp in 2006. It was created in the format of an open-air museum where the main exhibits are the dwellings reconstructions of different time periods. The complex is located on the territory of the Partizansky district of the Primorsky region.

Interactive educational programs are held here annually. The complex events are worth special attention. The brightest and most visited ones are ethnic holidays Maslenitsa and Ivan Kupala. Unlike educational programs, these events are of considerable interest to the sole visitors.

There is a steady stream of visitors at present that indicates that the complex is in demand and has been integrated into the socio-cultural space of the region.

Ключевые слова: музей под открытым небом, реконструкция, археология, Скансен, Приморский край, этнография, удэгейцы.

Keywords: open-air museum, reconstruction, archaeology, Skansen, the Primorsky Region, ethnography, Udegei. 
Музейно-образовательный комплекс «Палеодеревня» расположен на территории бывшей воинской части в нескольких километрах от деревни «Боец Кузнецов» Партизанского района Приморского края (25 км. от г. Находка). Проект «Палеодеревня» реализован Муниципальным бюджетным учреждением культуры «Музейно-выставочным центром г. Находка» при поддержке партнеров - Приморской региональной молодежной краеведческой общественной организации «КЛИО», МБОУ ДОД «Дом детского и юношеского туризма и экскурсий» г. Находка, Института истории, археологии и этнографии народов Дальнего Востока ДВО РАН.

Основой для реализации проекта послужил детский археологический лагерь, с 1998 г. организуемый Музейно-выставочным центром и Институтом истории и археологии, существующий и по сей день. Участники лагеря занимаются изучением территории Екатериновского городища - поселения эпохи империи Цзинь и государства Восточное Ся (XIII в.) [3]. Руководит раскопом научный сотрудник сектора средневековой археологии Института Т.А. Васильева.

Археологический памятник Екатериновское городище - это классическое горное городище, построенное в чашеобразном склоне сопки. Городище Площадь городища примерно 27 гектаров. По периметру возведен оборонительный вал, длиною около 2,2 км. Городище было построено по заранее разработанному плану и служит хорошим примером укрепленных поселений XIII века в Приморье. Интересен тот факт, что городище, скорее всего, не было разграблено - нет следов сражений и крупных пожаров. Вероятнее всего, население организованно покинуло город и перешло для обороны в более крупный населенный пункт [3].

Первоначально, еще до появления идеи строительства комплекса, на тер-

Реконструкция жилища Кроуновской культуры раннего железного века. 2005 г.

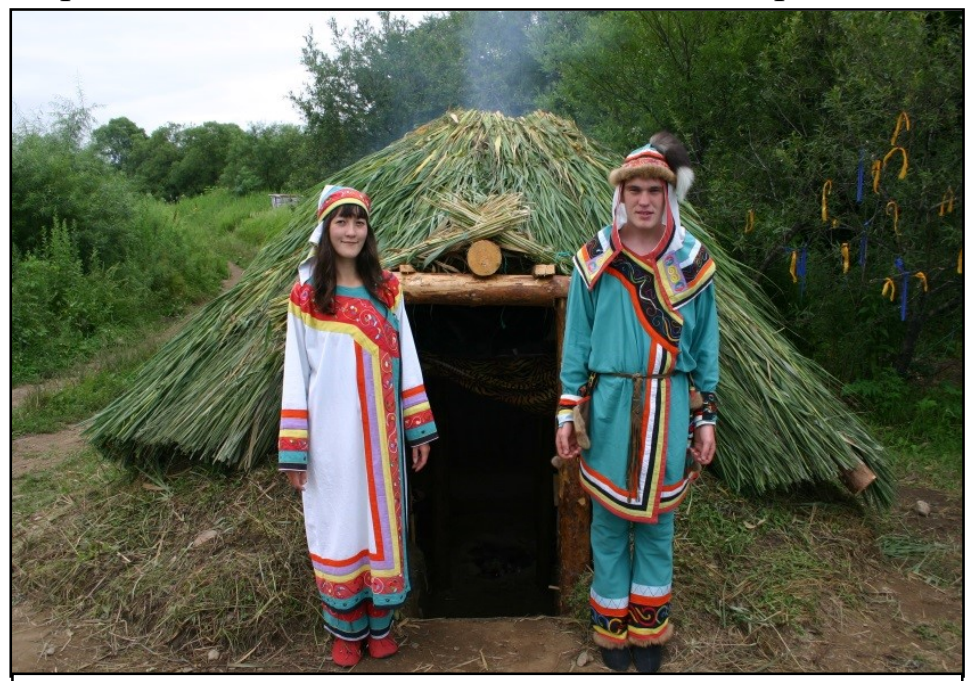

ритории археологического лагеря летом 2005 г. было реконструировано жилище раннего железного века Кроуновской археологической культуры. Руководил постройкой преподаватель ДДЮТиЭ и археолог В.В. Анохин. Жилище было небольшим - всего 3,5 м на 3,5 м. Процесс реконструкции и получившаяся в результате постройка вызвали живой интерес у участников лагеря. 
Успешный опыт 2005 г. стал основой для новых реконструкций. В 2006 г. появилась концепция музея под открытым небом, состоящего из реконструкций сразу нескольких эпох. Как место для реализации была выбрана расформированная военная часть №13025, расположенная в 350 м от главных ворот Екатериновского городища.

Основной идеей проекта стало создание интерактивного комплекса археологических архитектурных реконструкций, который бы стал не только музеем, но и образовательным центром. Важная роль здесь отводилась детям. Они должны были стать не только посетителями, но и активными участниками жизни будущего музея. Проект разработали В.В. Анохин и М.Б. Нургалиева.

Юг Российского Дальнего Востока всегда имел сложный этнический состав. Фактическое закрепление этой территории происходило за счет переселения сюда людей из других регионов страны. Согласно переписи, проведенной в 2010 г., в Приморском крае проживали представители 40 народов. Большая часть всего населения - русские $(85,66 \%)$, на втором месте находятся украинцы $(2,55 \%)$ и корейцы $(0,96 \%)$. Еще 15 народов имеют численность более 1000 человек [5]. Культурная фузия стала причиной формирования особой региональной идентичности. Знание истории региона является её важным элементом.

Проект был направлен на решение следующих проблем:

1. Недостаточное использование в регионе историко-культурного и ландшафтного потенциала, как ресурса территории.

2. Отсутствие наглядности в изучении местной истории в образовательных учреждениях всех уровней.

3. Слабое использование прикладных, деятельных форм в музейном образовании.

4. Ограниченный объём научно-исторических знаний у детей, молодёжи и взрослых. Местному населению практически неизвестны история, культура, обычаи и быт древних народов и аборигенов Приморского края.

5. Отсутствие культуры и навыков общения с природой и природными материалами у детей и подростков.

Целью проекта стало создание экспериментальной площадки для поиска новых форм исторического, этнографического и экологического образования:

- изучения и реконструкции древних технологий домостроительства и ремесел,

- изучения духовной культуры аборигенов Южного Приморья,

- формирования экологической и этнической культуры у детей и молодежи.

Для достижения этой цели были поставлены следующие задачи:

1. Построить музейный ландшафтный комплекс «Палеодеревня», состоящий из нескольких реконструированных жилищ разных исторических эпох. 
2. Разработать механизм образовательной и научной деятельности на базе комплекса «Палеодеревня»: образовательные программы, мастерские (археологические, гончарные, художественные, древних ремёсел), опыты по экспериментальной археологии.

3. Переоборудовать территорию бывшей военной части, расположенной у подножия Екатериновского городища, в образовательное пространство детского научно-оздоровительного археологического лагеря «Палеодеревня».

Проект «Палеодеревня» был поддержан администрацией Находкинского городского округа и Партизанского муниципального района. В 2006 г. он был подан на грантовый конкурс Благотворительного фонда В.О. Потанина «Меняющийся музей в меняющемся мире» в номинации «Музей и новые образовательные программы». Конкурс проводился при поддержке Министерства культуры и массовых коммуникаций РФ и Ассоциации Менеджеров культуры. Победа в конкурсе и полученный денежный грант, вместе с имеющимися средствами организаций и партнеров, дали возможность воплотить идею в жизнь. Надо сказать, что подобные площадки, занимающиеся историческими и этнографическими реконструкциями, существуют во многих странах мира, в том числе и в России. Но в Приморском крае на тот момент не было еще ни одного подобного культурного объекта.

Строительство комплекса началось 1 июня 2006 г. В строительстве активное участие приняли дети-участники археологического лагеря. Участие в реконструкции жилых и хозяйственных построек сопровождалось лекциями о реконструируемых эпохах.

Музей был построен в течение 1 месяца и 20 дней и отрылся 9 августа 2006 г., в международный день коренных народов мира. К откры-

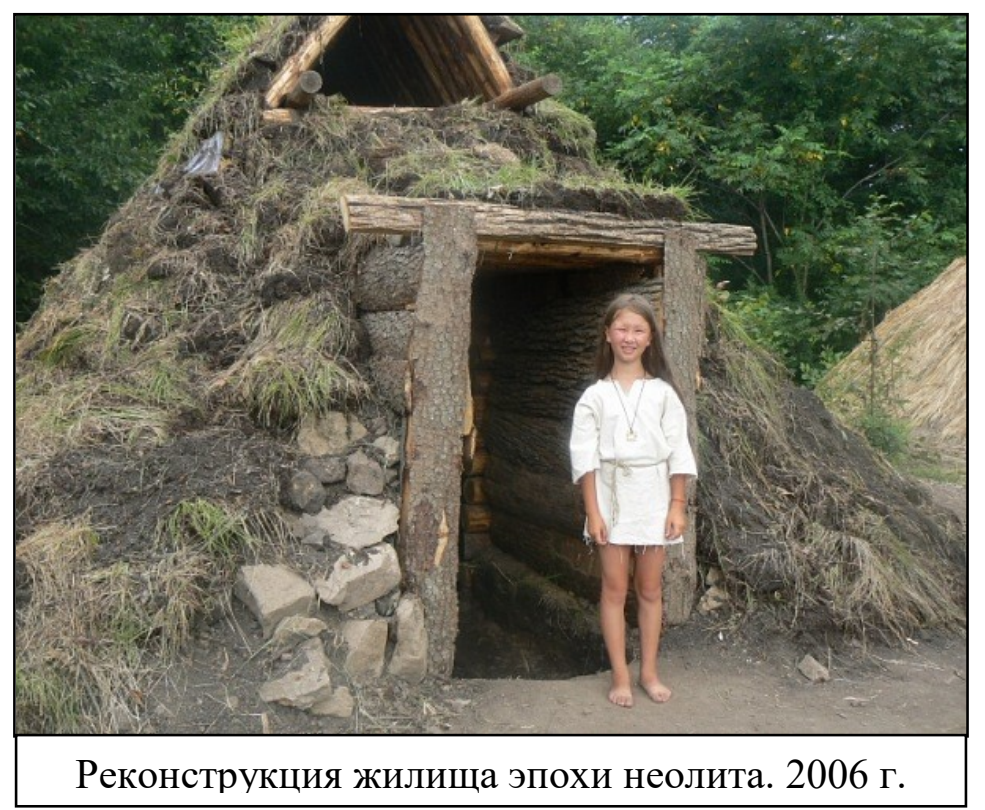

тию были построены:

- два легких шалаша эпохи верхнего палеолита (38000-9000 л.н.) [6],

- жилище эпохи неолита (80007000 л.н.) [7],

- жилище раннего железного века кроуновской культуры (25001900 л.н.) [10], и - три средневековых (XII-XIII 
вв.) постройки: жилое строение, навес и печь для обжига глиняных изделий, и амбар-летник. Строительство сразу трех реконструкций средневековья обусловлено близостью к Екатериновскому городищу

В последующие годы музей был несколько раз обновлен: заново отстроены реконструкции, постепенно пришедшие в негодность под воздействием приморского климата, жилище эпохи неолита и шалаши палеолита были перенесено на другое место для улучшения логистики. Кроме того, были достроены сцена и большой жилой дом, сейчас использующийся как хозяйственное помещение и для принятия туристов в зимнее время.

За первые три месяца работы, с августа по октябрь 2006 г., были проведены экскурсии для более 3000 посетителей. Основным туристическим продуктом стала экскурсионно-образовательная программа «Секреты древних». Кроме отмеченных выше эпох, программа рассказывала также и о коренных малочисленных народах дальнего востока - прежде всего удэгейцах.

Дети - участники строительства - выступили в роли аниматоровэкскурсоводов. Они находились внутри реконструкций и были одеты в соответствующую времени одежду. Приходящим посетителям они рассказывали о той эпохе, к которой относилась реконструкция, отвечали на вопросы, проводили простые демонстрации и мастер-классы.

Была разработана образовательная программа «Деревня мастеров». Эта программа делает акцент на мастер-классах по работе с природными материалами, прежде всего с глиной. Под руководством мастера дети учатся лепить сосуды ленточно-жгутовым способом и на ручном гончарном круге. Кроме того экскурсоводы рассказывают об обработке

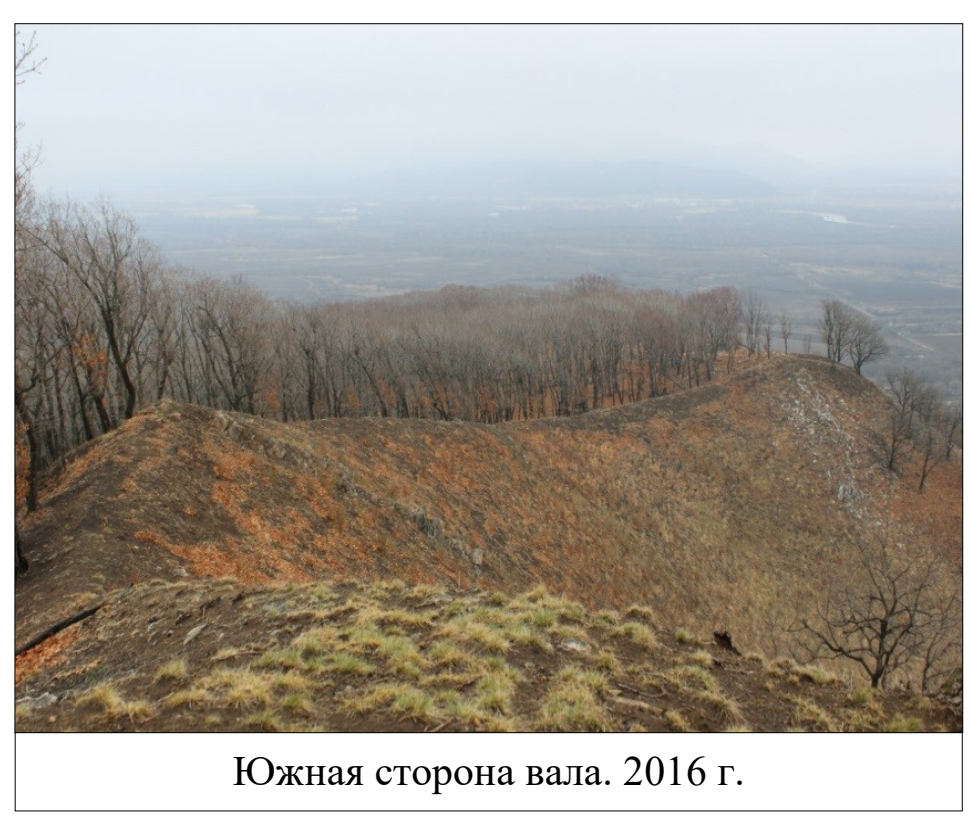
рыбьей кожи, распространенной $\mathrm{y}$ аборигенов Дальнего Востока как материал для одежды и обуви, а также о ткачестве и разжигании огня.

Большую популярность приобрели экскурсии по Екатериновскому городищу. Для их проведения на территории памятника было намечена экскурсионная тропа. Она идет от центральных ворот вдоль одной из улиц, между террасовидными площадка- 
ми, постепенно поднимаясь к юго-восточному внутреннему городу, и выходит на южную сторону вала. Отсутствие деревьев по этой стороне помогает гостю лучше понять оборонительные возможности крепости. С этой же стороны вала открывается вид на Золотую долину и Екатериновский скальный массив, в котором располагается археологический памятник верхнего палеолита - пещера им. Географического общества.

Пещера была открыта в 1963 г. спелеологами-любителями, членами Приморского филиала Всесоюзного географического общества Е. Г. Лешком и В. И. Шабуниным. При обследовании в ней были найдены кости ископаемых животных. Научное исследование этой пещеры началось в 1964 г. Во время раскопок так же были обнаружены каменные изделия человека и расколотые им кости. Благодаря этим находкам впервые появилась возможность датировать палеолит Приморья [8].

Основную часть посетителей составляют организованные группы учащихся школ и вузов городов и поселков юга Приморского края. Комплекс очень удобен для организации выездных уроков в начале учебного года, когда важно не только дать учащимся новые знания, но и сплотить учебный коллектив.

Большую роль в жизни комплекса играют событийные мероприятия. К настоящему моменту сложилась система 4-х основных праздников, каждый из которых проводится в определенный момент годового цикла:

- «Новогодние гуляния в Палеодеревне», празднующиеся в первые дни нового года;

- «Масленица» проводимый в масленичную неделю; - «Ивана Купала» отмечаемый в первые выходные ию-

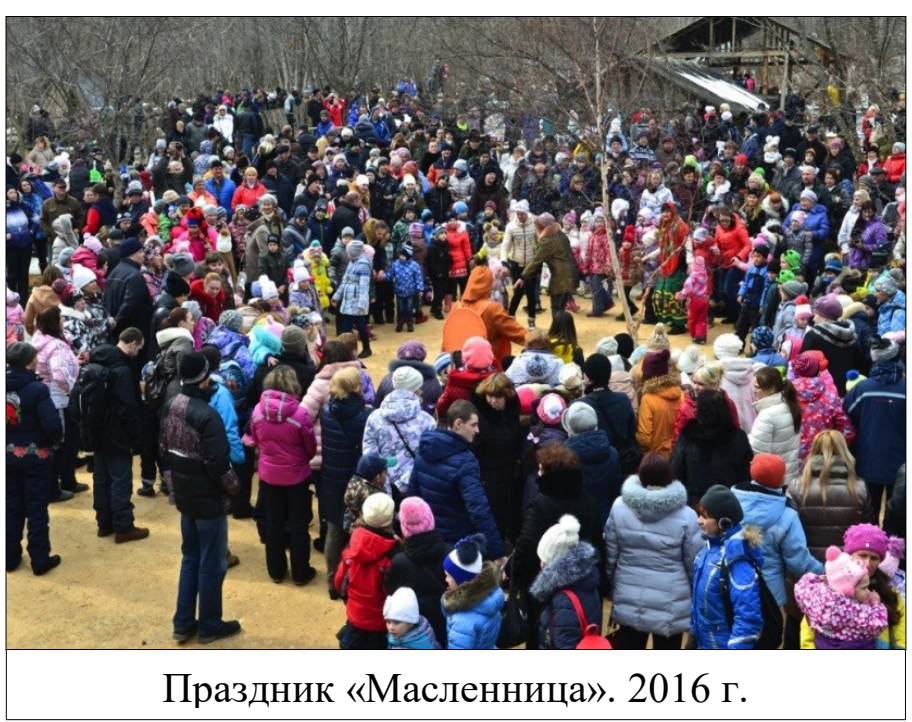
ля;

- «День Тигра», приходящийся на конец сентября.

В эти дни основная часть посетителей - это семьи с детьми разного возраста либо одиночные посетители. Для удобства приезжающих на площадку приглашаются кухни различных этнических диаспор - прежде всего татар и корейцев. В праздниках обязательно участвуют мастера декоративно-прикладного творчества, которые не только представляют свои изделия на ярмарке, но и проводят мастер-классы. 
Для организованных школьных групп, желающих самостоятельно отпраздновать «День Тигра» и «Масленицу», в течении недели до события проводятся тематические программы.

На площадке комплекса были реализованы несколько крупных проектов. Первым стал проект «Найди в себе КЛАД», реализованный в 2008 г. в рамках грантовой программы «Новый день», организованной ОАО АКБ «РОСБАНК» совместно с Детским фондом ООН (ЮНИСЕФ). Участники проекта проводили свои небольшие исследования по археологии, экологии, прикладному или художественному творчеству. Результаты этих исследований были опубликованы в созданном для этого журнале «КЛАД».

Второй номер этого журнала был посвящен первому крупному событийному мероприятию комплекса - детскому этническому фестивалю «Живой источник». Фестиваль прошел в июле 2009 г. на средства Программы «Новый день» ОАО АКБ «Росбанк», в дальнейшем фестиваль получил финансовую поддержку администрации Находкинского городского округа. Участниками фестиваля стали детские этнические коллективы, представляющие культуры разных народов: русских, татар, корейцев, нанайцев, удэгейцев, дагестанцев, украинцев, индийцев и т.д.

Фестиваль проходил ежегодно с 2009 по 2018 гг, а в 2019 г. программу фестиваля совместили с реализацией проекта «Этностиль Приморья».

Проект «Этностиль Приморья» был реализован Находкинской татаро-башкирской общественной организацией "Туган тел" совместно с Приморской региональной молодежной краеведческой общественной организации «КЛИО». Проект стал победителем конкурса "Фонда Президентских грантов» в 2017 г. [9]. Целью проекта было привлечь внимание молодого поколения к своей этнической культуре через исследовательскую и творческую работу. Участники занимались разработкой ряда аксессуаров и предметов одежды на основе и с использованием материалов культуры народов Приморского края. Для презентации результатов работы летом 2019 г. в программу фестиваля «Живой источник 2019» было включено дефиле, а осенью того же года пошла выставка созданных коллекций в Музейно-выставочном центре г. Находка.

Комплекс неоднократно становился победителем и призером различных туристических и музейных конкурсов. «Палеодеревня» признана лучшим реализованным проектом конкурса «Меняющийся музей в меняющемся мире» в 2007 г., получила диплом 1 степени в Российском конкурсе этнокультурных проектов в 2008 г., стала обладателем диплома конкурса «Лидер турбизнеса Приморья» в 2009 г.

Необходимо осветить также и проблемы комплекса, возникшие за время строительства и работы комплекса. Для комплекса особенно остро стоит земельный вопрос. Изначально территория военной части принадлежала министерству обороны, но позднее была частично передана лесному хозяйству Партизанского муниципального района. Неопределен- 
ность границы переданных земель значительно усложнила процедуру взятия в аренду необходимой территории. Несмотря на все усилия руководства «Палеодеревни», земельный вопрос до сих пор остается не решенным. Неопределенность с землей заставляет руководство ограничивать объем средств, вкладываемых в благоустройство территории и строительство долговременных капитальных сооружений. Вопрос финансирования также стоит достаточно остро. Большую часть времени комплекс находится на самоокупаемости. Из-за этого персонал комплекса зачастую вынужден отдавать предпочтение финансово выгодным событиям и программам в ущерб научной и, в меньшей степени, образовательной части.

С другой стороны, сам факт самоокупаемости комплекса говорит о его важности для культурного пространства территории. Количество людей, за год посетивших комплекс, достаточно стабильно и колеблется от 2834 ч. (2012 г.) до 4625 ч. (2015 г.) Из этого можно сделать вывод о востребованности предлагаемых комплексом услуг. Хотя стоит отметить постепенное сокращение интереса к экскурсиям и образовательным программам общего плана в сторону событийных мероприятий и приуроченных к ним тематических программ. Комплекс вынужден учитывать эту тенденцию, чтобы сохранить финансовую эффективность. Для исправления этой ситуации необходима государственная финансовая поддержка комплекса и кооперация с коммерческими структурами.

Еще одним важным фактом, доказывающим глубокое проникновение в культурную среду Приморского края, является использование названия комплекса «Палеодеревня» как нарицательного имени, обозначающее архитектурные реконструкции под открытым небом. Этот термин звучит не только в устной речи. Его можно увидеть в тексте новостных изданий, например, в статье ««Восточные лета»: магия Изумрудной долины»: «...Палеодеревня «Изумрудная долина» была выбрана организаторами этно-фестиваля «Восточные лета» неспроста, какое место может лучше подойти для подобного мероприятия, если не поляна, на которой 40 тысяч лет назад жили приморские племена....» [1]; в художественной литературе «...Слухов вокруг этого необычного проекта ходило много. Поначалу непонятно было: то ли этническое поселение, то ли очередной спортивно-развлекательный центр. А теперь ясно: безалкогольная зона! Причем «древнеприморский» сектор здесь - настоящая палеодеревня...» [4]. Кроме того этот термин можно увидеть и в научной среде - например статья о создании комплекса реконструкций на о. Попова в Приморском крае называется «Палеодеревня на острове Попова». Хотя нельзя сказать, что в регионе он стал русскоязычным аналогом термину «скансен», как называют в Европе музеи под открытым небом, состоящий из реконструкций и оригинальных построек [2].

Завершая статью, можно сделать следующий вывод: комплекс «Палеодеревня», построенный в 2006 г. стал совершенно новым явлением в культурной среде Дальнего Востока. Об этом говорит количество 
людей, посетивших комплекс в первые годы его существования. В дальнейшем же поток посетителей стал немного меньше. Но стабильность этого потока на протяжении последних лет говорит о твердых позициях комплекса на рынке образовательных услуг и сформированном за эти годы интересе общества к работе «Палеодеревни». За 12 лет своей работы комплекс стал важной частью социокультурного пространства Приморского края.

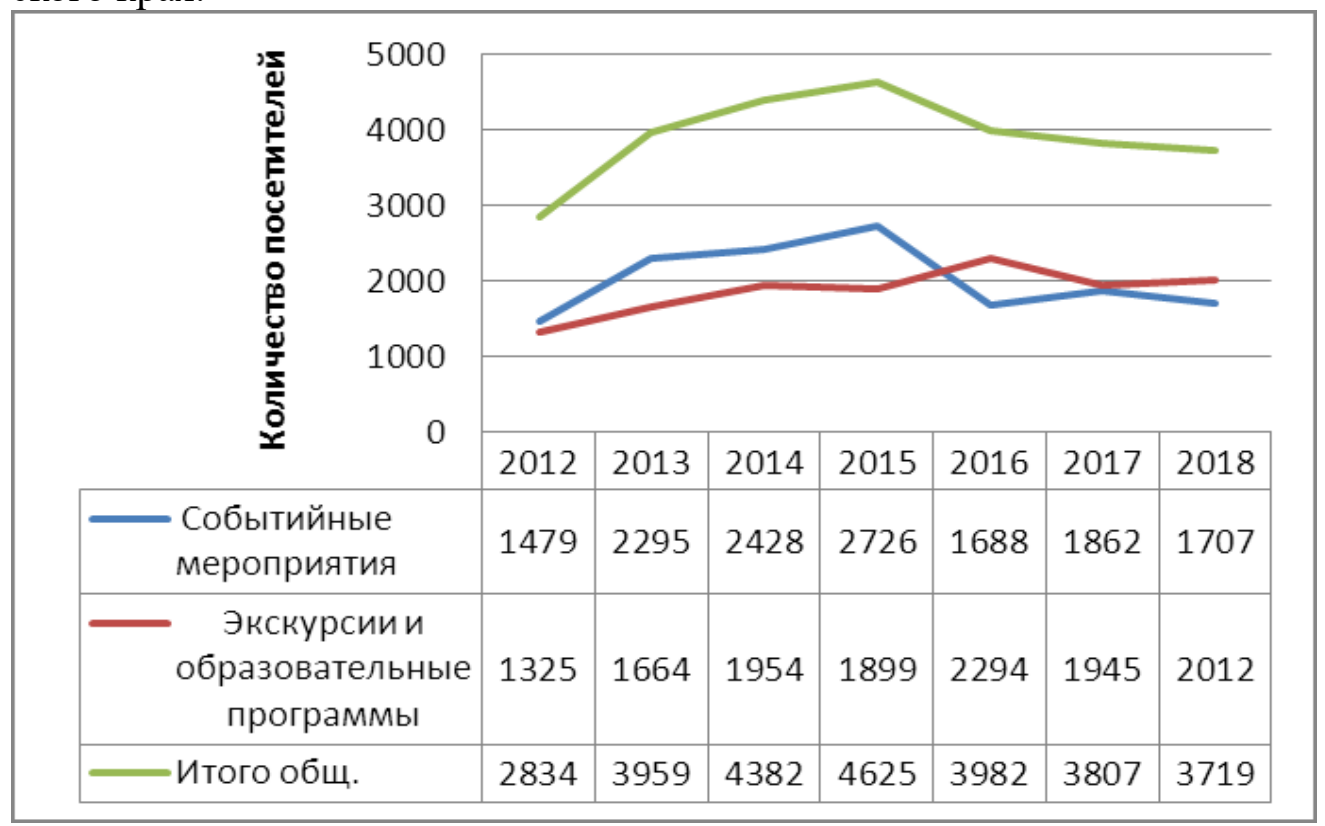

Таблица 1. Статистика посещаемости комплекса «Палеодеревня»

\section{Примечания}

1. «Восточные лета»: магия Изумрудной долины // Примпогода. URL: https://primpogoda.ru/news/ecology/vostochnye_leta (дата обращения: 2.04.2019).

2. Палеодеревня на острове Попова / Белоглазова С. Б. [и др.] // Вестник Дальневосточного отделения РАН. 2009. №1 .

3. Васильева Т. А. Итоги исследования Екатериновского городища // Средневековые древности Приморья. Владивосток : Дальнаука, 2016. Вып. 4. С. 110-126.

4. Кузьмин В. Изумрудная долина // Литературный меридиан. 2013. №5 // ЛитБук. URL: http://litbook.ru/article/3321 (дата обращения: 27.05.2019).

5. Итоги Всероссийской переписи населения 2010 года в отношении демографических и социально-экономических характеристик отдельных национальностей // Федеральная служба государственной статистики. URL: http://www.gks.ru/free_doc/new_site/perepis2010/croc/results2.html (дата обращения: 2.04.2019). 
6. Крупянко А. А. Палеолит Приморья: проблемы периодизации // Вестник Бурятского государственного университета. 2015. №7. С. 101109.

7. Некоторые проблемы каменного века Приморья (по материалам совместных российско-японских экспедиций) / Кузнецов А. М. [и др.] // Вестник Дальневосточного отделения РАН. 2005. №4. 113-124.

8. Окладников А. П., Деревянко А. П. Далекое прошлое Приморья и Приамурья. Владивосток : Дальневост. кн. изд-во, 1973. 440 с.

9. Проект «Этностиль Приморья» // Фонд Президентских грантов. URL: https://xn--80afcdbalict6afooklqi5o.xn--p1ai/public/application/item?id $=$ dcbc645d-d1af-48c8-8ab3-093039359091. (дата обращения:02.04.2019).

10. Сергушева Е. А., Морева О. Л. Земледелие в Южном Приморье в I тыс. до н.э. : карпологические материалы поселения Черепаха-13 // Вестник археологии, антропологии и этнографии. 2017. №4 (39). С. 195204.

\section{References}

1. «Vostochnye leta»: magija Izumrudnoj doliny ["Eastern summer": The magic of the Emerald valley] // Primpogoda (Primpogoda]. URL: https://primpogoda.ru/news/ecology/vostochnye_leta (2.04.2019). [In Russ.].

2. Paleoderevnja na ostrove Popova [Paleovillage on Popov's island] / Beloglazova S. B. [et al] // Vestnik DVO RAN [Bulletin of the Far Eastern Branch of the Russian Academy of Sciences]. 2009. №1. [In Russ.].

3. Vasilyeva T.A. Itogi issledovanija Ekaterinovskogo gorodishchja [The study results of the Catherine Settlement] // Srednevekovye drevnosti Primor'ja [Medieval Antiquities of Primorye]. Issue 4. Vladivostok, 2016. Pp. 110 - 126. [In Russ.].

4. Kuzmin V. Izumrudnaja dolina [Emerald Valley] // Literaturnyj meridian [The literary meridian]. 2013. № 5 // LitBuk [Litbook]. URL: http://litbook.ru/article/3321/ (27.05.2019). [In Russ.].

5. Itogi Vserossijskoj perepisi naselenija 2010 goda $\mathrm{v}$ otnoshenii demograficheskikh i social'no-ekonomicheskikh kharakteristik otdel'nykh nacional'nostej [Results of the 2010 All-Russian Population Census regarding the demographic and socio-economic characteristics of some nationalities] //Federal'naja sluzhba gosudarstvennoj statistiki [Federal State Statistics Service]. URL: http://www.gks.ru/free_doc/new_site/perepis2010 /croc/results2.html (2.04.2019). [In Russ.].

6. Krupyanko A.A. Paleolit Primor'ja: problemy periodizacii [The Paleolithic Age in Primorye: problems of periodization] // Vestnik Burjatskogo gosudarstvennogo universiteta [Bulletin of the Buryat State University]. 2015. №7. Pp. 101 - 109. [In Russ.].

7. Nekotorye problemy kamennogo veka Primor'ja (po materialam sovmestnykh rossijsko-japonskikh ekspedicij) [Some problems of the Stone Age in Primorye (based on joint Russian-Japanese expeditions)] / Kuznetsov 
A.M. [et al] // Vestnik DVO RAN [Bulletin of the Far Eastern Branch of the Russian Academy of Sciences]. 2005. №4. S. 113-124. [In Russ.]

8. Okladnikov A.P., Derevyanko A.P. Daljokoe proshloe Primor'ja i Priamur'ja [The distant past of Primorye and Priamurye]. Vladivostok, 1973. 440 p. [In Russ.]

9. Proekt «Etnostil' Primor'ja» [Project "Ethnostyle of Primorye"] // Fond Prezidentskikh grantov [The Presidential Grants Fund]. URL: https://xn-80afcdbalict6afooklqi5o.xn--p1ai/public/application/item?id=dcbc645d-d1af48c8-8ab3-093039359091 (2.04.2019). [In Russ.]

10. Sergusheva E.A., Moreva O.L. Zemledelije v Yuzhnom Primor'e v I tys. do n.e.: karpologicheskie materialy poselenija Cherepakha-13 [Agriculture in the Southern Primorye in the I millennium BC: carpological materials of Cherepakha-13 settlement] // Vestnik arkheologii, antropologii i etnografii [Archaeology, Anthropology and Ethnography Bulletin]. 2017. №4 (39). Pp. 195 - 204. [In Russ.] 
DOI 10.31443/2541-8874-2019-2-10-100-104

УДК 069.015:378.4(571.51)

Румянцева А.С., Епина М.Б., Терскова А.А.

Rumyantseva A.S., Epina M.B., Terskova A.A.
КУЛЬТУРНО-ПРОСВЕТИТЕЛЬСКАЯ, ОБРАЗОВАТЕЛЬНАЯ И МЕМОРИАЛЬНАЯ ДЕЯТЕЛЬНОСТЬ МУЗЕЯ СИБИРСКОГО ФЕДЕРАЛЬНОГО УНИВЕРСИТЕТА

\section{CULTURAL, EDUCATIONAL AND MEMORIAL ACTIVITIES OF THE MUSEUM OF THE SIBERIAN FEDERAL UNIVERSITY}

Музей Сибирского федерального университета сегодня осуществляет широкую культурно-просветительскую, образовательную и мемориальную работу, направленную на сохранение памяти о выдающихся ученых университета, о ветеранах, работавших в разные годы в стенах вуза, а также популяризацию научного и культурного наследия вуза, города и края. Из наиболее значимых проектов Музея СФУ можно назвать создание мемориальных именных аудиторий, подготовку цикла программ «Ректоры-фронтовики», работу клуба интересных людей «Персона» и другие.

The Museum of the Siberian Federal University (SFU) today carries out wide cultural, educational and memorial work aimed at preserving the memory about the outstanding scientists and veterans having worked in different years at the University as well as at promoting the scientific and cultural heritage of the higher educational institution, the city and the region. Among the most significant projects of the SFU Museum are the creation of memorial nominal classrooms, preparation of a series of programs "Rectorswar veterans", the work of the club of interesting people "Person" and others.

Ключевые слова: Музей СФУ, мемориальные аудитории, университетский музей.

Keywords: museum of the Siberian Federal University, memorial auditoriums, university museum.

Университетский музей - это особое явление в культурном пространстве России, Сибири и края. Первый сибирский университетский музей был образован при Томском Императорском университете в 80-е г. XIX в. Действовал он, опираясь на общественную инициативу. С 20-х гг. $\mathrm{XX}$ в. начинается полоса «государственного» формирования университетских музеев, что приводит к значительному росту числа музеев при вузах страны. Сегодня создание университетских музеев продолжается. Только на территории Западной Сибири функционирует 75 музеев высших учебных заведений [1, с. 242].

Музей Сибирского федерального университета - это молодой музей, недавно отметивший свое десятилетие. Базой для создания музея 
стали «Музей геологии» и «Музей истории» Государственного университета цветных металлов и золота, вошедшего в состав Сибирского федерального университета в 2006 году. Позже в состав музея был включен Сектор археологии и этнографии, созданный на основе лаборатории археологии и этнографии Гуманитарного института СФУ, занимающейся не только хранением собранных материалов, но и активной научно-исследовательской деятельностью. СФУ.

В статье будут представлены основные направления работы Музея

Следует подчеркнуть, что деятельность любого музея связана с сохранением исторической памяти. Музейная работа имеет разную направленность и состоит из документирующего, научно-просветительского, воспитательного, идеологического, аксиологического направлений, позволяющих сохранять, транслировать и передавать накопленный опыт, интерпретировать культурное наследие [2, с. 85]. Главными задачами Музея СФУ, как музея университетского, в первую очередь, являются образовательная и культурно-воспитательная. Целевой аудиторией музея, в интересах которой музей проводит выставочно-экспозиционную и образовательную работу, в основном, выступает студенческая молодежь.

Попадая в музей, посетители принимают участие в экскурсиях, во время которых их знакомят с историей вузов-предшественников, вошедших в состав СФУ, и самого Сибирского федерального университета, с историческими событиями страны, которые происходили в период образования этих вузов, получают ответы на появившиеся в ходе экскурсии вопросы. История Сибирского федерального университета воспитывает у молодежи гордость за Альма-матер, уважение к науке и осознание научного потенциала родного вуза.

Одним из значимых проектов Музея СФУ является создание именных аудиторий. Мемориальное обустройство подобных аудиторий направлено на знакомство и формирование памяти университетского сообщества и широкого круга лиц о прошлом СФУ, моделирует отношение к будущему, формирует университетскую идентичность. Именные аудитории обеспечивают сохранение и пропаганду научного наследия выдающихся деятелей науки и образования, работавших в СФУ и являвшихся его гордостью, дают доступ к информации об их жизненном пути, научной и трудовой деятельности студентам, преподавателям и самой широкой аудитории, помогают трансляции знаний о развитии науки и образования в городе и крае. Подобные аудитории поддерживают репутацию СФУ в среде профессионального сообщества, развивают его положительный имидж. В настоящий момент таких действующих аудиторий девять, среди них именные аудитории д.ф.-м.н., профессора В.С. Соколова, д.ф.м.н., академика Л.В. Киренского, д.т.н., профессора Л.В. Енджиевского, д.т.н. Н.П. Абовского, д.т.н., профессора Н.Х. Загирова, к.т.н, профессора В.Д. Наделяева, к.т.н., профессора С.А. Подлесного, член-корр. РИА В.Н. Гулидова. Именные аудитории - это лекционные залы, кабинеты-библио- 
теки, компьютерные классы, которые посещает большой поток студентов, преподавателей, гостей СФУ. Работа в этом направлении активно продолжается. На выходе проекты именных аудиторий ректоров В. Борисова, А. Ставера, почетного профессора, лауреата Нобелевской премии Осаму Шимомуры, мемориальный объект, посвященный Д.И. Менделееву и его периодической таблице.

Сегодня Музей СФУ выступает как центр научно-исследовательской работы, которая имеет большой образовательный и просветительский потенциал. Особенно активная научно-исследовательская работа Музея СФУ касается поиска, сохранения и популяризации информации памяти о ветеранах Великой Отечественной войны. К 70-летию Победы СССР в Великой Отечественной войне Музеем, совместно с ТВ СФУ, был создан проект «Ректоры-фронтовики», посвященный руководителям вузов-предшественников СФУ: Василию Борисову, Владимиру Дарьяльскому, Александру Дрокину, Наилю Загирову. Сектором истории Музея СФУ были собраны материалы о 189 участниках боевых действий в годы ВОВ, работавших в вузах, вошедших в состав Сибирского федерального университета. Огромную помощь в такой работе оказывают студенты, направленные в музей в целях закрепления теоретического материала на практике. Активная научно-исследовательская работа ведется со студентами в рамках военно-исторических чтений, проводимых сектором истории Музея СФУ и военно-патриотическим клубом «Витязь» Гуманитарного института СФУ. Студенты и преподаватели СФУ имели возможность встретиться с ветеранами Великой Отечественной войны, из первых уст узнать об особенностях быта и жизни солдат на фронте, прикоснуться к военной повседневности, что вызывает большой интерес и положительный отклик. В программу работы клуба «Витязь» так же включены конференции, квесты, интеллектуально-артистические турниры.

Большое культурно-просветительское и образовательное значение имеет проект Музея СФУ - клуб интересных людей «Персона», начавший свою работу в 2014 г. Работа клуба в виде неформальных встреч предоставляет возможность познакомиться и пообщаться с наиболее выдающимися деятелями культуры и науки Красноярска и края. В рамках работы клуба были проведены встречи с заслуженным художником России Владимиром Зеленовым, народным художником России Валерьяном Сергиным, заслуженным архитектором России Арэгом Демирхановым, д.б.н. Н. Сетковым, основателем высшего архитектурного образования в Красноярском крае Галиной Лашук, преподавателем Академии музыки и театра Евгением Лауком, актером театра и кино Яковом Аленовым, д.т.н., профессором СФУ Петром Поляковым, народным художником Бурятии Даши Намдаковым.

Немаловажное значение имеет эстетическое воспитание молодежи посредством организации регулярных художественных выставок, встреч и мастер-классов в галереях музея «Презентация», «Акцент», других выставочных площадках Музея. За годы этой деятельности публике были 
представлены работы известных художников, скульпторов и мастеров декоративно-прикладного искусства города, края, ближнего и дальнего зарубежья. Проводятся ежегодные отчетные выставки студенческих работ института Архитектуры и дизайна, выставки детского рисунка.

Проект Музея под названием «Наши», имеет культурно-образовательное значение, воспитывающее уважение к университету и научному сообществу педагогов и студентов, направлен на знакомство с достижениями и уникальными творческими возможностями сотрудников университета и самих студентов. Проект действует с 2012 г. В его рамках студенты познакомились с творчеством преподавателей СФУ: заведующего лабораторией художественной ковки ИЦМиМ С.А. Колчина, доцентов кафедры рисунка, живописи и скульптуры Н.В. Муриной, Д.О. Шавлыгина, профессора кафедры С.Е. Лошакова, старшего преподавателя Ю. Абаева, зав. кафедрой Е.Г. Карепова, д.ф.н., профессора А. Свитина, старейшего преподавателя кафедры А.В. Зражевского, одного из основателей высшего архитектурного образования в Красноярском крае Галины Лашук, с выставками студенческих работ ИАД «Скульптурная композиция в архитектурной среде», «Города из шелка», выставкой ювелирных и декоративно-прикладных работ кафедры литья Политехнического института. Мероприятия, регулярно проходящие в выставочных залах Музея СФУ, дают возможность молодым людям прикоснуться к творчеству талантливых художников, скульпторов, своих педагогов, воспитывают гордость за университет.

Популяризация эстетического воспитания продолжена в издании ежегодных настольных календарей, в публикациях иллюстраций в Гуманитарном научном журнале университета, в готовящемся к печати подарочном каталоге произведений из художественного фонда Музея.

В 2016 г. в Музее начал работу клуб любителей кино «КинОкеан», который предлагает всем желающим принять участие в просмотре и обсуждении интересных кинофильмов и наиболее ярких шедевров мирового кино. В течение трех лет прошло более двух десятков встреч, на которых были показаны картины «Мужчина и женщина» (реж. Клод Лелуш), «Дирижер» (реж. Павел Лунгин), «Изгнание» (реж. Андрей Звягинцев) и другие. Кинокартины заставляют задуматься о философии жизни не только молодежь, но и старшее поколение.

В феврале 2019 г., накануне открытия Зимней универсиады, на кампусе СФУ была установлена скульптура «Трансформация» всемирно известного Даши Намдакова. Это культурное событие стало грандиозным не только для СФУ, но и для города, края и страны в целом.

Рассмотрев далеко не все направления работы музея и подводя итоги, можно сказать, что Музей СФУ значительное внимание уделяет мемориальной работе, осуществляет широкую культурно-просветительскую и образовательную деятельность, активно участвуя в формировании культурного ландшафта университетской среды и городского сообщества. 


\section{Примечания}

1. Белоусова Н.А. Музеи высших учебных заведений юга Западной Сибири. Кемерово : КемГУ, 2016. 415 с.

2. Овчинникова 3. А. Роль музеев в формировании, поддержке и трансляции исторической и культурной памяти // Вестник культуры и искусств. 2018. № 1 (53). С. 82-89.

\section{References}

1. Belousova N.A. Muzej vysshikh uchebnykh zavedenij juga zapadnoj Sibiri [Museums of higher educational institutions of the South of Western Siberia.] Kemerovo, 2016. 415 p. [In Russ].

2. Ovchinnikova Z.A. Rol' muzeev $v$ formirovanii, podderzhke $i$ transljacii istoricheskoj i kulturnoj pamjati [The role of museums in the formation, support and translation of historical and cultural memory // Vestnik kultury $i$ iskusstv [Bulletin of culture and arts]. 2018. № 1 (53). Pp. 82-89. [In Russ]. 
DOI 10.31443/2541-8874-2019-2-10-105-114

УДК 069.12(571.63)

Гульбина А.А., Жущиховская И.С.

Gulbina A.A., Zhushchikhovskaya I.S.

\author{
ИНТЕРАКТИВНЫЙ ПОДХОД \\ К ПОПУЛЯРИЗАЦИИ НАУЧНЫХ ЗНАНИЙ \\ (ОПЫТ МУЗЕЯ «ПРИРОДА МОРЯ И ЕЕ ОХРАНА») \\ INTERACTIVE APPROACH \\ TO POPULARIZING SCIENTIFIC KNOWLEDGE \\ (THE EXPERIENCE OF THE MUSEUM \\ “THE SEA NATURE AND ITS PROTECTION")
}

Статья рассматривает формы и приемы интерактивного взаимодействия с посетителями, которые практикует единственный в России музей, посвященный природе моря и ее охране. Тематическая структура музея включает различные направления и носит междисциплинарный характер. Интерактивная методика, которая используется для каждого из направлений, значительно повышает эффективность просветительско-образовательной работы.

The article considers the forms and approaches of interaction with the visitors practiced by the only museum in Russia devoted to sea nature and its protection. The museum thematic structuring includes different directions and is of interdisciplinary character. The interactive methodic applied for each thematic direction significantly increases the efficiency of educational work.

Ключевые слова: музейно-образовательная среда, интерактивность, морская и прибрежная экология, междисциплинарный подход.

Keywords: museum educational environment, interactivity, marine and coastal ecology, interdisciplinary approach.

Одним из важнейших инструментов просветительско-образовательной деятельности современного музея является интерактивный подход, позволяющий значительно повысить эффективность представления и восприятия тематической информации. Интерактивные приемы успешно используются в работе музеев разного профиля - краеведческих, исторических, естественнонаучных, художественных, мемориальных. Существующие сегодня формы коммуникативного диалога между музеем и его аудиторией весьма разнообразны: мастер-классы, игровые и учебные программы, инсценировки, праздники, квест-проекты, программы для самостоятельного информационного поиска с помощью компьютерных технологий и др. Все они направлены на создание оптимальных условий для погружения экскурсантов и посетителей в содержательное пространство музея, для популяризации научных знаний и их лучшего усвоения, для развития исследовательских навыков. Интерактивный диалог может осу- 
ществляться как через посредство специалиста-экскурсовода, так и без его участия $[1 ; 4 ; 5 ; 10 ; 12 ; 13]$.

Внедрение и использование принципов интерактивного подхода имеет большое значение и для самого музея, способствуя росту его творческо-инновационного потенциала. Постоянный поиск новых возможностей и решений является главным условием динамичного развития, соответствующего быстро меняющимся реалиям современного мира. В этой связи обобщение и анализ опыта разных музеев в области интерактивных методов работы представляет практический и в определенной степени теоретический интерес. Задача нашей статьи - рассмотреть возможности использования форм и приемов музейной интерактивной коммуникации на примере музея «Природа моря и ее охрана».

Музей «Природа моря и ее охрана», созданный в 1977 г., входит в состав «Дальневосточного морского заповедника» филиала Национального научного центра морской биологии ДВО РАН и в настоящее время относится к ведомству Министерства науки и высшего образования Российской Федерации. Музей находится на о-ве Попова Владивостокского городского округа Приморского края, часть территории которого выделена Дальневосточному морскому заповеднику, для создания островного ботанического сада и ведения просветительской деятельности. В России нет другого города, в составе которого находилась бы территория самого высокого природоохранного статуса - государственный природный заповедник. Это обстоятельство в значительной мере определяет тематический профиль музея. По своему общественному назначению музей «Природа моря и ее охрана» как и большинство российских музеев, является научно-просветительским учреждением. Адресная аудитория музея учащиеся школ и ВУЗов, представители различных возрастных и социальных групп населения, семейные коллективы. По ежегодным данным учета посещаемости, 60-70\% экскурсантов составляют дети младшего, среднего и старшего школьного возраста. Активный экскурсионный сезон в музее продолжается с мая по октябрь, поскольку в теплое время года о-в Попова является одним из любимейших мест отдыха как для жителей региона, так и его гостей. В мае, сентябре и октябре музей в рамках маршрута выходного дня активно посещают школьники.

Важнейшей составляющей деятельности музея с первых лет его работы является популяризация научных знаний в области экологии морских акваторий и прибрежных территорий юга Дальнего Востока. Этой задаче было изначально подчинено создание постоянной тематической экспозиции в залах музея. Заметным событием в жизни музея стала организация в 1996 г. Центра экологического просвещения, в который вошли учебный кабинет, комната для проведения массовых мероприятий, небольшая гостиница, столовая. Были созданы условия, позволяющие принимать туристов-экскурсантов с целью просвещения по экологическим программам на маршруты выходного дня с проживанием на базе Центра [6]. 
С конца 1990-х гг. отдельным направлением стала разработка серии туристическо-познавательных маршрутов по острову, представляющих собой своего рода продолжение музейной экспозиции, но уже в «живой» природе. В 2007-2009 гг. на территории музея «Природа моря и ее охрана» был реализован инновационный проект историко-культурного музейного комплекса под открытым небом «Наследие» («Палеодеревня») [11]. Таким образом, информационное пространство музея за годы его работы существенно расширилось и в настоящее время носит междисциплинарный характер, что позволяет не только показать разнообразие природы моря и морского побережья, обозначить актуальные проблемы его сохранения, но и совершить экскурс в историю взаимоотношений человека и окружающей среды на территории юга Дальнего Востока.

Музей постоянно ищет и внедряет новые методы и направления работы с акцентом на интерактивные и междисциплинарные подходы к организации просветительско-образовательного процесса [6; 9]. Далее мы рассмотрим некоторые приемы и формы интерактивного подхода к популяризации научных знаний в музее «Природа моря и ее охрана».

Постоянная экспозиция. Сегодня экспозиция в залах музея включает разделы: «История заповедного дела в России», «Дальневосточная наука - морю», «Животные и растения залива Петра Великого», «Экосистемы коралловых рифов», «Рыбное хозяйство Дальнего Востока», «Марикультура», «Дальневосточный морской заповедник», «Экология древнего человека». Видеоряд экспозиции состоит из натурных экспонатов фауны и флоры моря и суши, макетов, моделей, графическо-текстовых материалов, фотоматериалов. Раздел «Животные и растения залива Петра Великого» дополнен специальными бассейнами-аквариумами с морской водой и обитающими в них животными - морскими звездами, крабами, моллюсками и др.

Знакомство с основной, постоянной, экспозицией включает два вида коммуникации между посетителем (экскурсантом) и той информацией, которую несут музейные экспонаты. Первый вид может быть обозначен условной схемой «посетитель - экскурсовод - музейный экспонат». С первых лет работы музея практикуется организация групповых экскурсий с обязательным сопровождением специалистом-лектором, который должен не только профессионально рассказать о представленных в витринах экспонатах, но и объяснить природные явления и процессы. Важная роль отводится умению вовлечь посетителей в активную беседу, вызвать ответную реакцию на полученную информацию, пробудить любопытство к пониманию природы моря и осознание своей ответственности за ее сохранение. В конце экскурсии посетителям предлагается не просто оставить запись в Книге отзывов, а выразить свои впечатления в образной форме - написать пожелания морю на листочке и приклеить его на силуэтный макет кита, размещенный возле входа в музей.

Второй вид музейной коммуникации мы обозначаем как «nосетитель - музейный экспонат». Роль экскурсовода в этом случае минималь- 
на, акцент делается на самостоятельное восприятие и анализ музейной информации.

Предлагаются различные текстовые формы диалога между экскурсантом и музеем. Большое внимание уделяется детской и подростковой аудитории, которая является наиболее многочисленной среди посетителей музея. Несколько лет назад сотрудницей музея О.Г. Алексеенко была разработана игра-квест «Музей вопросов и ответов», рассчитанная на детей среднего и старшего школьного возраста [2]. В основе игры лежит вопросно-поисковый метод, развивающий творческую активность и способность к восприятию информации, позволяющий глубже понять язык музейной экспозиции. Суть игры состоит в том, что за отведенное время - 30 минут - надо самостоятельно найти в музейной экспозиции ответы на вопросы, указанные в карточке участника.

Для другой адресной аудитории - семейных групп с детьми 5-9 лет в рамках проекта «Наука в путешествии Приморье» были разработаны квесты по музею - «Этажи моря, или как Циприсы ${ }^{1}$ себе местожительство искали» и «Круговорот воды в природе, или Путешествие капельки». Для обеспечения маршрута-квеста экспозиция музея была адаптирована под целевую семейную группу. Для экспонатов, задействованных в маршруте, создавались специальные детские этикетки. При этом важно было подчеркнуть, что главную роль в маршруте по музею играют экспонат и экспозиция, а дополнительные этикетки только глубже раскрывают их суть. Для самостоятельной работы на маршруте были созданы путеводители. Основная задача путеводителя - создать ситуацию интерактивного общения с музейными экспонатами при помощи интересных и несложных заданий. Так, путеводитель «Этажи моря» и адаптированная экспозиция помогали узнать, что море, как многоэтажный дом, заселено различными обитателями сверху донизу. И каждое животное само определяет место своего обитания: толщу воды или дно, прибрежные воды или глубины. Игровой путеводитель «Круговорот воды в природе, или Путешествие капельки» в образной форме представлял последовательность этого природного цикла. Путеводитель, которым можно пользоваться без помощи экскурсовода, содержит задания для выработки навыка ориентации в музейной экспозиции (план маршрута по залам), доступные объяснения, иллюстрации [8].

Особой формой коммуникации «посетитель - музейный экспонат» является знакомство с обитателями бассейнов-аквариумов с морской водой. В них живут относящиеся к охраняемым видам дальневосточный трепанг, приморский гребешок, гигантская устрица, а также морские звезды, ежи, крабы, рыбы. Один из бассейнов устроен таким образом, что посетители могут, не доставая из воды, подержать в руках заинтересовавшее их животное, понаблюдать за его поведением. Можно

1 Циприс - личинка Морского желудя (морское животное из подотряда усоногих раков). 
увидеть, как передвигается по песку еж, убегает от морской звезды гребешок, искусно маскируется на дне камбала. Такое непосредственное прикосновение к живой природе моря интересно посетителям всех возрастов и позволяет не только лучше усвоить полученные во время экскурсии знания, но и получить огромный эмоциональный заряд.

В качестве заключительного этапа посещения музея экскурсантам предлагается просмотр документального видеофильма «Дальневосточному морскому заповеднику посвящается» (авторы - Г.Н. Шаликов и А.В. Ратников). Фильм знакомит с биоразнообразием морской среды и уникальными прибрежными ландшафтами южного Приморья.

Туристическо-познавательные маршруты. Маршруты по экскурсионным тропам на о-ве Попова мы рассматриваем как продолжение процесса экологического просвещения и воспитания, который начинается в залах музея. Специфика этих экскурсий состоит в органичном соединении отдыха и восприятия новой информации. Рекреация и обучение вовсе не исключают, а хорошо дополняют друг друга при грамотной организации экскурсии, когда усвоение новых знаний происходит в непринужденной обстановке, в окружении природы. Привлекательность природных троп заповедников вообще и Дальневосточного морского биосферного заповедника в частности, состоит в возможности проводить экскурсии в условиях хорошо сохранившейся природной среды и демонстрировать редкие, а зачастую и уникальные природные объекты. В процессе экскурсии на маршруте экскурсовод решает следующие задачи: образовательную - дает информацию о природных или историко-культурных объектах; просветительскую - учит слушателей замечать различные факторы антропогенного воздействия и оценивать воздействие человека на окружающую среду; воспитательную - способствует воспитанию экологической культуры поведения человека на природе [7; 14].

Тематика экскурсионных маршрутов по о-ву Попова: «Геологическое прошлое и настоящее острова Попова», «Растительный мир острова Попова», «Обитатели литорали и сублиторали», «История открытия и освоения островов залива Петра Великого русскими мореплавателями». Были также разработаны два маршрута по наиболее интересным историко-культурным местам острова - «Экология древнего человека (экскурсия по археологическим памятникам)» и «Фортификационные сооружения начала XX века». Программа познавательных маршрутов соединяет естественнонаучную и гуманитарную составляющие [7].

Экскурсия «Обитатели литорали и сублиторали» приглашает посетителей музея совершить вместе с экскурсоводом небольшое путешествие по приливно-отливной зоне морского побережья. Во время наибольшего отлива можно, даже не замочив ног, наблюдать, фотографировать и зарисовывать морских животных и растения в естественных условиях их обитания. Комментарии экскурсовода помогают увидеть особенности адаптации живых организмов к осушению и прибою, вертикальную зональность, плотность поселения, обеспечивающую размножение и дру- 
гие экологические проявления. В многочисленных выбросах на берегу моря можно собрать небольшую коллекцию раковин моллюсков, панцирей морских ежей и крабов. Затем в учебном кабинете специалисты помогают сделать определения этих животных и написать этикетки.

Экскурсия «Геологическое прошлое и настоящее острова Попова» включает знакомство с разделом «Геология острова Попова» в экспозиции музея и прогулку по тематическому маршруту, проходящему по живописному побережью с выходами горных пород. Участникам маршрута раздаются информационные карточки, на которых обозначены основные этапы геологической истории Земли для лучшего восприятия рассказа экскурсовода, на туристической тропе выстраивается геологическая шкала. Геологическое строение о-ва Попова позволяет увидеть свидетельства разных этапов формирования морского побережья и слагающих его горных пород, проследить изменения природных условий в течение длительного времени - периоды похолодания и потепления климата, колебания уровня моря и изменения береговой линии. Особое внимание уделяется тем изменениям ландшафта, которые обусловлены деятельностью человека в недавнем прошлом и настоящем. Во время экскурсии ее участники могут собрать коллекцию камней (морская галька, обломки горных пород) и затем определить их, используя коллекцию горных пород, представленных в музее.

Экскурсия «Экология древнего человека» проходит по местам археологических памятников. Это остатки одного крупного поселения и нескольких прибрежных стоянок. Памятники относятся к янковской археологической культуре эпохи палеометалла и датируются 1 тыс. до н.э. Отличительной особенностью этой культуры была ориентация на активный морской промысел. Свидетельства этому в виде раковинных куч есть в нескольких местах на острове. Небольшая экспозиция материалов из археологических памятников (артефакты, кости рыб, раковины моллюсков) представлена в музее, с нее начинается знакомство с первыми обитателями острова.

Очень часто продолжением экскурсионного маршрута становится мастер-класс по изготовлению глиняной посуды методами древних гончаров. Это одно из самых популярных интерактивных занятий, предлагаемых музеем. Его задача - научить работать с одним из основных сырьевых материалов, освоенных человеком в далеком прошлом. Программа мастер-класса была разработана в 2002 г. И.С. Жущиховской [9]. Проводит мастер-класс сотрудник музея Г.Б. Корниенко. Для лепки посуды используется достаточно качественная глина, залегающая в непосредственной близости от места большого поселения янковской культуры. Судя по составу керамики из памятника, эта глина использовалась когда-то первобытными гончарами. Занятие включает не только лепку сосудов, но и обработку их поверхности и декорирование различными узорами. Практическое занятие сопровождается рассказом об истории происхождения и 
развития навыков изготовления глиняной посуды, о ее месте в жизни древних людей.

Передвижная выставка-театр «Море - наш дом». Это особая форма интерактивной популяризации знаний в области экологии моря, являющаяся инновационным проектом музея «Природа моря и ее охрана». Период наиболее активной работы выставки пришелся на 2000-2010 гг. Выставка-театр демонстрировалась в дошкольных и школьных учреждениях Приморского края.

Выставка-театр построена на сочетании видеоряда, состоящего из стендов и натурных экспонатов, и театрального действия, создающего атмосферу художественной коммуникации. Экскурсовод рассказывает об экспонатах видеоряда, а спектакль-сказка «оживляет» рассказ, наполняет его выразительными образами обитателей моря. В качестве актеров задействованы школьники. Персонажи спектакля - морские звезды, рыбы, крабы и др. По ходу спектакля в него активно вовлекаются маленькие зрители, перевоплощающиеся в тех или иных морских животных и принимающие участие в сказочном действии. Таким образом, возникает эмоциональный эффект сопереживания, сочувствия живым обитателям моря, что является важным условием воспитания у детей гуманного отношения к природе, желания сохранить и защитить ее.

Музейный комплекс под открытым небом «Наследие». Создание музейных комплексов историко-культурной направленности под открытым небом изначально предполагает их интерактивный характер: в таких местах посетитель получает возможность почувствовать себя частью нового для него пространства культуры. Это может быть культура древних времен, реконструированная по археологическим источникам, либо культура традиционная, известная по материалам этнографии [3].

Наш музейный комплекс под открытым небом представляет собой размещенный в природном ландшафте ансамбль моделей в натуральную величину жилых, хозяйственных и ритуальных объектов древних и традиционных культур юга Дальнего Востока, созданный по оригинальным археологическим и этнографическим материалам [11]. Дополняют картину копии и подлинные образцы предметов материальной и духовной культуры - керамическая посуда, национальные костюмы, шаманские атрибуты и др. На территории комплекса, помимо познавательных экскурсий, проводятся различные игровые занятия, праздники, задача которых пропаганда идеи неразрывной связи человека и природы, экологическое воспитание. Например, для школьников младшего и среднего возраста проводится праздник «День мигрирующего лосося», тематика которого связана с морской и речной экологией, исконно традиционным для населения юга Дальнего Востока рыболовным промыслом. Интерактивный сценарий праздника включает элементы игры, соревнования и театрализации.

В заключение отметим, что в статье рассмотрено далеко не все разнообразие интерактивных приемов коммуникации с посетителями, ко- 
торые использует в своей работе музей «Природа моря и ее охрана». Поиск инноваций идет постоянно, их подсказывает сама практика общения с музейной аудиторией и динамичные реалии современного мира. Как показывает наш опыт, интерактивные методы музейной работы весьма востребованы сегодня и имеют огромный потенциал для дальнейшего развития.

\section{Примечания}

1. Алексеева Н. Д., Рябова Е. В. Квест-экскурсия как инновационная форма экскурсионной деятельности // Вектор науки ТГУ. Серия: Педагогика, психология. 2015. № 1 (20). С. 14-17.

2. Алексеенко О. Г. Изучаем музей с детьми // IX Дальневосточная конференция по заповедному делу. Владивосток, 20-22 окт. 2010 г. : материалы конф. Владивосток : Дальнаука, 2010. С. 37-40.

3. Афанасьев О. Е., Вольхина В. В. Роль, значимость и функции скансенов как туристского ресурса территории и репрезентантов народных традиций природопользования // Современные проблемы сервиса и туризма. 2015. № 4. С. 12-21.

4. Баранова Н. П. Воспитание историей. Интерактивные программы в детском историческом музее // Вестник детско-юношеского туризма. 2011. №2. С. 60-63.

5. Биксалеев А. А. Интерактивные формы взаимодействия с посетителями как современные тенденции развития музея // Молодой ученый. 2016. №22. C.236-238. URL: https://moluch.ru/archive/126/34966/ (дата обращения: 23.03.2019).

6. Гульбина А. А. Интерактивные методы работы в музее «Природа моря и ее охрана» // IV Дальневосточная конференция по заповедному делу. Владивосток : Дальнаука, 1999. С.54-55.

7. Гульбина А. А. Интерпретация экспозиции музея и природных троп Дальневосточного морского заповедника // Материалы межрегиональной научно-практической конференции по экологическому образованию, воспитанию и просвещению. Ч. 1. Биробиджан : ДВГСГА, 2007. С. $120-123$.

8.Гульбина А. А. Путешествие в науку: первый семейный межмузейный маршрут по музеям Дальневосточного отделения РАН // ХІІ Дальневосточная конференция по заповедному делу : материалы конф. Биробиджан : ИКАРП ДВО РАН, 2017. С. 157-159.

9. Гульбина А. А., Жущиховская И. С. Музей «Природа моря и ее охрана» // Вестник ДВО РАН. 2003. №4. С. 175-179.

10. Гусейнова А. Г. Особенности интерактивных форм работы музеев образовательных организаций Ярославской области // Современные проблемы сервиса и туризма. 2016. Т. 10, №2. С. 64-70.

11. Палеодеревня на острове Попова / Жущиховская И. С., Белоглазова С. Б., Гульбина А. А. Данилова О. Н. // Вестник ДВО РАН. 2009. № 1. C. 121-126. 
12. Макаров Д., Егунова О. Интерактивные технологии в работе современного музея и их влияние на культуру и образование // Власть. 2013. № 5. C. 56-58.

13. Сапанжа О. С. Турист в современном музее: философия просвещения, технология развлечения // Вопросы музеологии. 2010. №2. С. 103-106.

14. Чижова В.П. Школа природы. Экологическое образование в охраняемых природных территориях. М. : Эколого-просветительский центр «Заповедники», 1997. 160 с.

\section{References}

1. Alekseeva N.D., Ryabova E.V. Kvest-ekskursija kak innovacionnaja forma ekskursionnoj dejatel'nosti [Quest-excursion as an innovative form of excursion activity] // Vektor nauki TGU. Serija: Pedagogika, psikhologija [Science vector of TSU. Series: Pedagogy, Psychology]. 2015. № 1 (20). Pp. 14-17. [In Russ.].

2. Alekseenko O.G. Izuchaem muzej s det'mi [Museum study with children] // IX Dal'nevostochnaja konferencija po zapovednomu delu. Vladivostok, 20-22 Okt., 2010 : materialy konf. [IX Far Eastern conference in reserve management and studies: conference proceedings]. Vladivostok, 2010. Pp. 37-40. [In Russ].

3. Afanasyev O. E., Volkhina V. V. Rol', znachimost' i funkcija skansenov kak turisticheskogo resursa territorii i representantov narodnykh tradicij prirodopol'zovanija [The role, significance and functions of skansenmuseums as touristic resource of the territory and representatives of environmental management folk traditions] // Sovremennyje problemy servisa i turizma [Modern problems of service and tourism]. 2015. № 4. Pp. 12-21. [In Russ.].

4. Baranova N.P. Vospitanije istoriej. Interaktivnye programmy $\mathrm{v}$ detskom istoricheskom muzee [Education through history. Interactive programs in the children's historical museum] // Vestnik detsko-junosheskogo turizma [Bulletin of children-youth tourism]. 2011. №2. Pp. 60-63. [In Russ.].

5. Biksaleev A.A. Interaktivnyje formy vzaimodejstvija s posetitelyami kak sovremennye tendencii razvitija museja [Interactive forms of communication with visitors as modern tendencies of museum development] // Molodoj uchenyj [Young scientist]. 2016. №22. Pp.236-238. URL: https://moluch.ru/archive/126/34966/ (23.03.2019). [In Russ.].

6. Gulbina A.A. Interaktivnyje metody raboty v muzee "Priroda morya i ejo okhrana" [Work interactive methods in the museum "The sea nature and its protection"] // IV Dal'nevostochnaja konferencija po zapovednomu delu [Far Eastern conference in reserve management and studies]. Vladivostok, 1999. Pp.54-55. [In Russ.].

7. Gulbina A.A. Interpretacija ekspozicii museja i prirodnykh trop Dal'nevostochnogo morskogo zapovednika [The interpretation of museum exposition and natural routes of the Far East marine reserve] // Materialy 
mezhregional'noj nauchno-prakticheskoj konferencii po ekologicheskomu obrazovaniju, vospitaniju i prosveshcheniju. Ch.1. [Materials of the international scientific-practical conference in ecological education]. Part 1. Birobidzhan. 2007. Pp. 120-123. [In Russ.].

8. Gulbina A.A. Puteshestvje v nauku: pervyj semejnyj mezhmuzejnyj marshrut po musejam Dal'nevostochnogo otdelenija RAN [Journey into science: first family inter-museum route over the museums of the Far Eastern branch of the Russian Academy of Sciences] // XII Dal'nevostochnaja konferencija po zapovednomu delu: Materialy konferencii [XII ${ }^{\text {th }}$ Far Eastern conference in reserve management and studies: conference proceedings]. Birobidzhan. 2017. Pp. 157-159. [In Russ.].

9. Gulbina A.A., Zhushchikhovskaya I.S. Muzej “ Priroda morya i ejo okhrana" [The museum "The sea nature and its protection"] // Vestnik DVO RAN [Bulletin of the RAS FEB]. 2003. № 4. Pp. 175-179. [In Russ.].

10. Guseynova A.G. Osobennosti interaktivnykh form raboty muzeev obrazovatel'nykh organizacij Yaroslavskoj oblasti [The features of the educational institutions museum work of the Yaroslavl region] // Sovremennye problemy servisa i turizma [Modern problems of service and tourism]. 2016. Vol. 10, №2. Pp. 64-70. [In Russ.].

11. Paleoderevnja na ostrove Popova [The Paleo-village at Popov's island]/ Zhushchikhovskaya I.S., Beloglazova S.B., Gulbina A.A., Danilova O.N. // Vestnik DVO RAN [Bulletin of RAS FEB]. 2009. № 1. Pp. 121 - 126. [In Russ.].

12. Makarov D., Egunova O. Interaktivnye tekhnologii $\mathrm{v}$ rabote sovremennogo muzeja i ikh vlijanie na kul'turu i obrazovanije [Interactive technologies in the activity of modern museum and their influence on culture and education] // Vlast' [Power]. 2013. № 5. Pp. 56-58. [In Russ.].

13. Sapanzha O.S. Turist $\mathrm{v}$ sovremennom muzeje; filosofija prosveshchenija, technologija razvlechenija [A tourist in the modern museum: the philosophy of education, technology of entertainment] // Voprosy muzeologii [Museology issues]. 2010. №2. Pp. 103-106. [In Russ.].

14. Chizhova V.P. Shkola prirody. Ekologicheskoje obrazovanije v okhranyaemykh prirodnykh territorijakh [The school of nature. Ecological education at the protected natural territories]. M., 1997. 160 p. [In Russ.]. 
DOI 10.31443/2541-8874-2019-2-10-115-121

УДК 069(571.54-4)+379.8.092-056.24

Бальжитова О.М.

Balzhitova O.M.

\section{МУЗЕЙ В СОЦИАЛЬНО-КУЛЬТУРНОЙ РЕАБИЛИТАЦИИ ЛЮДЕЙ С ОГРАНИЧЕННЫМИ ВОЗМОЖНОСТЯМИ ЗДОРОВЬЯ MUSEUM IN THE SOCIAL AND CULTURAL REHABILITATION OF THE PEOPLE WITH DISABILITIES}

В представленной статье автор рассматривает деятельность музея на современном этапе развития в рамках актуальной на сегодняшний день проблемы по доступности историко-культурного наследия для людей с ограниченными возможностями здоровья. Приводится опыт работы Национального музея республики Бурятия по обеспечению доступности музея для инвалидов.

The author of the article considers the activities of a museum at the present stage of the development within the framework of the actual problem of accessibility of historical and cultural heritage for people with disabilities nowadays. The experience of the National Museum of the Republic of Buryatia in ensuring the accessibility of the museum for people with disabilities is described.

Ключевые слова: музей, музейная деятельность, социально-культурная реабилитация, инвалиды, доступная среда.

Keywords: museum, museum activities, social and cultural rehabilitation, disabled people, accessible environment.

Современный музей, как показывает практика, превращается из традиционного учреждения, обеспечивающего сохранность и изучение исторических и культурных ценностей в многофункциональное учреждение культуры, способного решать общественно значимые задачи. В связи с этим меняется подход к организации музейного пространства, включающего в себя экспозиции, выставки, рекреационные зоны, входные зоны. Музеи начинают отходить от практики использования статичных, постоянных экспозиций и выставок, традиционных витрин с несменяемыми десятилетиями экспонатами. Меняется формат посещения музеев посетителями. Если раньше для большинства людей посещение музея рассматривалось через организованную экскурсию или «индивидуальный» осмотр экспозиции, тематической выставки, то сегодня формы посещения музея, методы работы с посетителями видоизменяются. Наряду с традиционными формами все больше популярными становятся: музейный праздник, музейная игра-викторина, мастер-класс, выездные мероприятия музея, семейные абонементы выходного дня и др. В стенах музея начинают проводить конференции, круглые столы, олимпиады, кружки. И 
количество этих форм постоянно меняется: одни формы появляются, другие исчезают, переставая соответствовать интересам аудитории.

Одновременно с поиском и организацией не только новых форм работы с посетителем, появляется необходимость в организации и самого времени пребывания посетителя в музее. В связи с этим разрабатываются рекреационные зоны для комфортного отдыха посетителя во время посещения музея. Рекреационные зоны могут иметь различные формы. Так на территории современного музея часто есть кафе, сувенирный магазин или киоск, холл с удобными сиденьями, пуфиками. Зоны рекреации могут иметь медиа-сопровождение, включающее в себя трансляцию музейных видеоматериалов на экраны: фильмы, информационные ролики, фотографии и др. Обязательным атрибутом зоны отдыха является возможность свободного доступа к сети Интернет.

Все это в целом делает работу музея эффективной, а сам музей «привлекательным» для посещения, в ходе которого у посетителя формируется позитивный музейный опыт.

Статистические данные последних лет свидетельствует о том, что, несмотря на сложное экономическое положение в стране, численность музеев увеличивается. Так за период 2001-2016 гг. число музеев, находящихся в ведении Министерства культуры России выросло на 30,1\% (с 2027 ед. до 2637 ед.). Соответственно идет рост посещаемости музеев находящихся в ведении органов управления в сфере культуры, которая увеличилась с 69,6 8 млн чел. в 2008 г. до 111,8 млн чел. в 2016 г.[3].

Также на результативность музейной деятельности влияет тот фактор, что сотрудники музея все больше применяют элементы музейной интерпретации, интерактивные способы подачи информации в экспозиции, выставке, экскурсии, путем выявления интересов и потребностей различных категорий посетителей. Довольно большую группу потенциальных посетителей музея составляют люди с ограниченными возможностями здоровья. И на сегодняшний день важной проблемой для современного музея является необходимость сделать возможным доступ к предметам культуры и искусства посетителям данной категории, так как все более актуальным становится решение проблем социально-культурной реабилитации граждан с ограниченными возможностями здоровья, в том числе и музейными средствами.

По данным Федеральной службы государственной статистики на 1 января 2018 года в России зарегистрировано 12,1 млн человек всех групп инвалидности (8,2\% населения России). Сегодня под понятием «инвалид» определяют лицо, имеющее нарушения здоровья, приводящие к ограничению жизнедеятельности и вызывающее необходимость его социальной защиты.

Под социокультурной реабилитацией инвалидов согласно стандартным правилам Организации объединённых наций $(\mathrm{OOH})$ по обеспечению равных возможностей для инвалидов, понимают комплекс мероприятий и условий, позволяющих им адаптироваться в стандартных со- 
циокультурных условиях: не только заниматься посильной работой, но и пользоваться накопленными человечеством достижениями культуры [2].

В 2008 году вступил в силу важнейший международный документ - Конвенция ООН о правах инвалидов, одобренная Генеральной Ассамблеей ООН. Конвенция призывает страны к решению задач безбарьерной среды - системы физической доступности для инвалидов общественных зданий, культурных мест отдыха, спортивных сооружений, транспорта [1]. Создание безбарьерной среды для лиц с ограниченными возможностями здоровья является одной из приоритетных задач социальной политики любого развитого общества, государства. Российская Федерация ратифицировала этот документ в 2012 году в Ф3-46 от 03.05.2012г. «О ратификации Конвенции о правах инвалидов». Также в нашей стране требования к работе с людьми с ограниченными возможностями были введены в рамках государственной целевой программы «Доступная среда» на 20112020 годы. Впоследствии Распоряжением Правительства РФ от 23 февраля 2018 г. №308-р срок действия программы был продлен до 2025 года включительно.

Принятие подобных нормативных актов, направленных на повышение качества разных сфер жизни людей с ограниченными возможностями здоровья дают положительные результаты. Так за последние годы в России наблюдается увеличение количества музеев, предоставляющих доступ к своим коллекциям посетителям с нарушениями слуха, зрения, опорно-двигательного аппарата, а также людям с умственными отклонениями; в музеях создаются тактильные галереи, отделы, экспозиции и выставки, появляются интерактивные экспонаты; разрабатываются специализированные музейные программы, разрабатываются новые экскурсионные маршруты. Подобная работа проводится в известных музейных учреждениях: Государственном Дарвиновском музее, музее-заповеднике «Царицыно», музее - гуманитарном центре «Преодоление» им. Н.А. Островского, музеях Московского Кремля, Мемориальном музее космонавтики, Государственном историческом музее, Государственном музее изобразительных искусств им. А.С. Пушкина, Государственном Эрмитаже и др. $[4]$.

Все больше российских музеев поддерживают и принимают участие в инклюзивной акции «Музей для всех!», посвященной вопросу вовлечения людей с инвалидностью и особенностями развития в активную культурную и социальную жизнь. Если в 2017 году в акции приняло участие 250 музеев из 65 регионов страны, то в 2018 году уже 350 музеев из 74 регионов. В рамках данной акции проходят экскурсии на жестовом языке, специальные 3D-копии картин, спектакли и выступления, подготовленные людьми с особенностями развития, тактильные мастер-классы и другие мероприятия, направленные на создание доступной и комфортной культурной среды для всех категорий посетителей.

ГАУК РБ «Национальный музей Республики Бурятии» в рамках реализации государственной программы «Доступная среда» активно ве- 
дет работу по обеспечению доступности музея, музейных выставок и мероприятий для лиц с ограниченными возможностями здоровья.

Для посещения музея маломобильными гражданами, в том числе инвалидами-колясочниками центральный вход художественного центра им. Ц.С. Сампилова и вход в выставочные залы оборудованы пандусом, приобретены переносные пандусы для лестничных маршей историкокраеведческого центра им. М. Н. Хангалова, имеется мобильный лестничный подъемник ROBY TO9 на гусеничном ходу. В помещениях выставочных залов усилиями музейных сотрудников по мере возможности обеспечивается пространство, необходимое для передвижения инвалидов-колясочников. В центрах оборудованы санитарные комнаты.

Художественный центр им. Ц. С. Сампилова оснащён современным звуковым оборудованием для проведения экскурсий посетителям с проблемами слуха - индукционной петлей, предназначенная для адаптации пространства для слабослышащих людей и помогающая человеку, пользующемуся слуховым аппаратом услышать речь экскурсовода. Помимо данного технического оборудования при посещении музея лица с проблемами слуха могут воспользоваться услугой мобильный видео-гид. Мобильный видео-гид представляет собой мобильное устройство (планшет), с помощью которого посетители с нарушениями слуха могут самостоятельно ознакомиться с видеофильмами, записанными на русском жестовом языке, не нуждаясь в сопровождении сурдопереводчика. Размещенный на планшете видео-гид состоит из десяти видеофильмов по разделам постоянных экспозиций художественного центра, снабжен звуковой дорожкой и направлен на знакомство с творчеством бурятских художников и с произведениями, представленными в музейных залах. Также в музее проходят выставки работ людей с ограниченными возможностями здоровья. Например, выставка творческих работ глухих художников России «На ладони Господней», выставка народных мастеров Баира Яндакова и Бадма-Доржо Тыкшеева «Маленькая страна».

В естественнонаучном центре (музей природы Бурятии) посетители с проблемами слуха могли самостоятельно ознакомиться с постоянной экспозицией «Путешествие по Бурятии» с помощью аудиогида. В настоящее время музей природы Бурятии размещается в художественном центре им. Ц. С. Сампилова, где ему было предоставлено помещение для построения новой экспозиции «Таёжная, озерная, степная». При проектировании новой экспозиции подъёмы и спуски экскурсионного маршрута были заложены с учётом их доступности для маломобильных граждан. В экспозиции музея природы представлен тактильный интерактив в виде стенда с экспонатами из разнообразных материалов для тактильного осмотра, некоторые экспонаты в экспозиции снабжены тактильными меховыми этикетками. С помощью данного интерактива посетители с проблемами зрения могут через осязание познакомиться с природой, ее разнообразными формами и видами. Знакомство с природой Байкальского регио- 
на также идет через аудиовизуальное сопровождение: фильмы, презентации, звуки птиц и животных.

Историко-краеведческий центр им. М. Н. Хангалова ведет постоянное пополнение коллекции экспонатов интерактивно-тактильной юрты, их насчитывается уже 41 предмет. В юрте через музейное экспозиционное пространство и тактильное изучение этнографических предметов можно получить дополнительные знания об истории, традиционной культуре бурят людьми с проблемами зрения через тактильное восприятие. Интерактив даёт возможность слабовидящим людям «увидеть», осязать предметы истории и традиций народа кончиками пальцев. Несомненно, важной стороной проекта является то, что роли экскурсовода могут примерить на себя люди с проблемами зрения. Так на ежегодной акции «Ночь музеев-2018» Национальный музей и РОФ «Общество без барьеров» представили инклюзивный проект «Закройте глаза и не бойтесь посмотреть на мир и заглянуть в себя» в тактильной юрте, где люди с проблемами зрения сопровождали обычных посетителей с повязкой на глазах как экскурсоводы и рассказывали об экспонатах, которые можно было потрогать руками. Проект «Тактильная юрта», пройдя серьёзную конкурсную комиссию, был участником международного фестиваля «Интермузей-2018 - Музеи и общество».

Многие из перечисленных проектов были претворены в жизнь в результате активного сотрудничества ГАУК РБ «Национальный музей республики Бурятии» с Региональным общественным фондом инвалидов-колясочников «Общество без барьеров», Бурятским Региональным Отделением Общероссийской Общественной Организации Инвалидов «Всероссийское Общество Глухих», Бурятской республиканской организацией «Всероссийское общество слепых». Члены общественных организаций не только принимали участие в реализации тех или иных проектов, но и апробировали их на практике.

Еще одним результатом совместной работы является доступность ежегодной музейной акции «Ночь в музее» для инвалидов. Общественники провели обучающий семинар для сотрудников музея, где рассказали об особенностях сопровождения людей с инвалидностью и продемонстрировали на практике приемы оказания услуг.

Национальный музей Бурятии активно участвует в процессе социализации и адаптации лиц с ограниченными возможностями здоровья и школьного возраста. Так МАОУ СОШ № 60 социальной адаптации детей-инвалидов г. Улан-Удэ, ГКОУ «Специальная (коррекционная) общеобразовательная школа-интернат I-II вида» являются постоянными участниками специально разработанных стационарных и выездных музейных программ для данной категории. Так для учащихся МАОУ СОШ № 60 сотрудниками музея разработана программа «Музей и дети».

Официальный сайт ГАУК РБ «Национальный музей республики Бурятия» снабжен версией для слабовидящих лиц. Имеется вкладка «Ау- 
диоэкскурсии». Аннотации к постоянным экспозициям переведены на шрифт Брайля.

К сожалению, многие музеи по-прежнему остаются недоступными для посещения большинству инвалидов в силу ряда причин. Так часть музеев расположена в зданиях, являющихся памятниками архитектуры и получить разрешение на строительство пандусов и лифтов, перепланировку помещений, расширение коридоров не всегда удается. Многие здания, в которых размещены музеи, построены до 1990-х гг., когда не существовало рекомендаций по созданию доступной среды, отсюда и сложности с переоборудованием зданий культурных учреждений. Экспозиции и выставки нуждаются в указателях, аудиогидах, этикетках, выполненных шрифтом Брайля, тактильных экспонатах и т.д. Инвалидам, желающим посетить тот или иной музей, не хватает информации о предстоящем визите. Несмотря на то, что у всех музеев есть свои официальные интернетсайты с подробным описанием проводимых мероприятий, на них не хватает информации касательно того, насколько конкретный музей, выставка, мероприятие адаптированы для посещения людей с ограниченными возможностями здоровья. Такое упущение заставляет потенциальных посетителей отказываться от посещения ими музея. Для самих сотрудников музея нужна специальная подготовка по обслуживанию инвалидов-посетителей, заключающаяся в изучение их психофизиологических особенностей (возраст, пол, патология и др.) и потребностей в тех или иных видах музейной деятельности. Так, например, подготовленные сотрудники по обслуживанию инвалидов-посетителей могут разрабатывать специальные маршруты движения по залам музея со специально разработанной экскурсией по данным маршрутам.

Музей во все времена являлся тем самым необходимым звеном между индивидом и культурной средой. И современные музеи не только должны сохранять связь, но расширять и укреплять свое присутствие в жизни общества и каждого человека. Активное участие музеев в социально-культурной реабилитации граждан с ограниченными возможностями здоровья может внести свой весомый вклад в приобщении к культурному и природному наследию человечества, в повышение качества жизни людей с ограниченными возможностями и особенностями развития.

\section{Примечания}

1. Булгакова В. В. Теоретические и методологические аспекты социокультурной интеграции инвалидов в музейной среде // Вестник Кемеровского государственного университета культуры и искусств. 2015. № 30. C. $96-106$.

2. Методические рекомендации по проведению в музеях социокультурной реабилитации инвалидов различных категорий. URL: http://muzeumhome.tosbs.ru/metodicheskie-materialy/muzei/79. (дата обращения: 05.03.2019). 
3. Статистика культуры 2016 : ежегод. справ. изд. о состоянии культуры Российской Федерации в цифрах. М. : 2017. 292 с. URL: https://stat.mkrf.ru/upload/statdoc/20180116.pdf (дата обращения: 05.03.2019).

4. Умеркаева С. Ш. Социально-культурная реабилитация инвалидов музейными средствами // Современные наукоемкие технологии. 2016. № 9, ч. 1. С. 171-175.

\section{References}

1. Bulgakova V.V. Teoreticheskije i metodologicheskije aspekty sociokulturnoj integracii invalidov $\mathrm{v}$ muzejnoj srede [Theoretical and methodological aspects of sociocultural integration of the peoples with disabilities in the museum environment] // Vestnik Kemerovskogo gosudarstvennogo universiteta kultury $i$ iskusstv [Bulletin of Kemerovo state university of culture and arts]. 2015. № 30. Pp. 96 - 106 [In Russ.].

2. Metodichekije rekomendacii po provedeniju $\mathrm{v}$ muzejakh sociokulturnoj reabilitacii invalidov razlichnykh kategorij [Methodic recommendations of sociocultural rehabilitation of different categories of people with disabilities]. URL: http://muzeumhome.tosbs.ru/metodicheskiematerialy/muzei/79 (05.03.2019) [In Russ.].

3. Statistika kultury 2016: ezhegodnoje spravochnoje izdanije o sostojanii kultury Rossijskoj Federacii v cifrakh [Culture statistics of 2016: annual reference book about the culture condition of the Russian Federation in figures]. M., 2017. 292 p. URL: https://stat.mkrf.ru/upload/statdoc/ 20180116.pdf (05.03.2019) [In Russ.].

4. Umerkaeva S.Sh. Social'no-kul'turnaja reabilitacija invalidov muzejnymi sredstvami [Socio-cultural rehabilitation of the people with disabilities by museum means] // Sovremennye naukojemkije tekhnologii [Modern scientific technologies]. 2016. № 9, p. 1. Pp. 171-175 [In Russ.]. 
УДК 069(571.54)

\section{Васильев В.М.}

Vasilyev V.M.

\section{ФОРМИРОВАНИЕ ЭКОЛОГИЧЕСКОЙ КУЛЬТУРЫ МУЗЕЙНЫМИ ТЕХНОЛОГИЯМИ FORMATION OF ECOLOGICAL CULTURE BY MUSEUM TECHNOLOGIES}

Статья посвящена опыту разработки и практике проведения экскурсии-лекции «Красная книга Республики Бурятия». Экскурсия и лекция основана на естественнонаучных исследованиях институтов СО РАН, расположенных в Бурятии, в области мониторинга редких видов млекопитающих и птиц, а также растений Республики Бурятия. Результаты этих исследований отражены в разделе экспозиции в музее.

The article is devoted to the experience of working out and practice of holding the excursion-lecture "The Red Book of the Buryatia Republic". The excursion-lecture is based on natural science research of the Institutes of the Siberian branch of the Russian Academy of Sciences situated in Buryatia in the area of monitoring rare species of mammals, birds and also the plants of the Republic. The results of this research are reflected at the exposition section in the museum.

Ключевые слова: Красная книга Республики Бурятия, экскурсия, лекция, экология, образование.

Keywords: the Red book of the Republic of Buryatia, excursion, lecture, ecology, education.

В наши дни чрезвычайно важным становится экологическое образование как подрастающего поколения, так и взрослых; формы его становятся все более разнообразными, в том числе применяются и музейные технологии. Термин «экологическое образование» введен на конференции, организованной Международным союзом охраны природы (МСОП) в 1970 г. и подразумевает «процесс и результат усвоения систематических знаний, умений и навыков в области воздействия на окружающую среду, состояния окружающей среды и последствий изменения окружающей среды» [5].

Экскурсия как нечто законченное, целостное, имеющее свои специфические функции и признаки, своеобразную индивидуальную методику, характеризуется как неотъемлемая часть идейно-воспитательной и культурно-массовой работы. Экскурсии могут конкретизировать уже имеющиеся знания, давать новые, развивать умение подходить к явлениям из жизни природы им людей, усиливать интерес к изучаемому и вызывать переживания в области чувств. 
Особенный развивающий и образовательной эффект имеет тематическая экскурсия, которая позволяет увидеть объект в совокупности других природных, исторических и культурных феноменов.

Байкальский регион - важная туристическая дестиниция, отличающаяся богатым культурно-историческим и природным наследием, важнейшим элементом которой выступает озеро Байкал - объект мирового культурного наследия.

Музей Бурятского научного центра Сибирского отделения Российской академии наук - подразделение БНЦ СО РАН, занимающееся проблематикой взаимодействия Природы и Человека в ее историческом развитии. В Музее действуют пять постоянных экспозиций. Их основу составляют результаты научных исследований бурятских ученых. В качестве основных направлений научной деятельности музея выступают: история развития науки в Бурятии; естественноисторическое развитие региона; взаимодействие человека и природы, этногенез и культурогенез народов Центральной Азии. В настоящее время взаимодействие школы и музея как эколого-образовательного и воспитательного института является одним из наиболее актуальных и приоритетных направлений работы естественнонаучных музеев. Решение проблемы ориентации музейного экологического образования на систему общественно значимых ценностей, выступающих в качестве стержня экологической культуры, является наиболее приоритетным направлением деятельности музея. Система ценностей определяет позицию человека по отношению к окружающему миру, регулирует его положение в обществе и проявляется в многообразной ориентации, деятельности и поведении человека. Музееведческие разработки в этой области имеют особое значение.

В настоящее время всё вышеизложенное подчеркивает актуальность разработки и внедрения экскурсии-лекции «Красная книга Республики Бурятия» в Музее БНЦ СО РАН», так как несет в себе познавательную и образовательно-воспитательную функции.

Наиболее приоритетной задачей музея Бурятского научного центра стало представление специализированной научной информации в том качестве, которое было бы комфортно для восприятия различными категориями посетителей.

Для формирования представления о фундаментальных естественнонаучных исследованиях и инновационных разработках институтов СО PАН, расположенных в Бурятии, в марте 2015 г. был создан пилотный вариант экспозиции «Естественнонаучные исследования Бурятского научного центра СО РАН: современность и перспективы», а в 2017 г. окончательный вариант [1].

Следует отметить, что среди школьников особый интерес вызвал один из наиболее аттрактивных разделов экспозиции - «Красная книга Республики Бурятия», посвященный подготовке и созданию региональной Красной книги (2013 г.) [6]. В данном разделе представлены коллекции чучел животных и гербарных образцов, в состав которых входят 
«краснокнижные» виды (Рис. 1.). Учитывая данный факт, на основе вышеупомянутого раздела была разработана экскурсия-лекция для учащихся СОШ, целью которой, наряду с информированием о подготовке, процессе естественнонаучных исследований и демонстрацией их результатов, было формирование чувства ответственности за будущую сохранность природных богатств региона [1].

Новаторским для музея явилось совмещение лекции и экскурсии с использованием метода диалогического общения. Такой, качественно новый, формат проведения экскурсии подразумевает размещение слушателей непосредственно в экспозиционном зале музея, где экскурсанты рассаживаются на заранее подготовленные места (изначально скамьи располагались рядами, но позже было принято решение о полукруговом расположении для создания комфортной обстановки - беседы), информация ведущего дополняется видеосюжетами о научно-исследовательской работе по мониторингу редких видов млекопитающих и птиц, а также растений Республики Бурятия. В перерывах экскурсанты могут пройти к экспонатам и задать вопросы, возникшие во время беседы.

Немаловажным в достижении поставленной цели можно по праву считать введение в экскурсию аудиосопровождения. Для этого была собрана коллекция аудиозаписей звуков животных, существенным образом, посредством web-cерфинга всемирной сети. Так, посетители во время экскурсии могут услышать голоса таких животных как: Длиннохвостая неясыть (Strix uralensis, Pallas, 1771), Кедровка, или ореховка (устар.) (Nucifraga caryocatactes, Linnaeus, 1758), Красноголовый нырок (Аythya ferina, Linnaeus, 1758), Сойка (Garrullus glandarius, Linnaeus, 1758), Хохлатая чернеть (Aythya fuligula, Linnaeus, 1758), Серебристая чайка (Larus argentatus, Pontoppidan, 1763), Шилохвость (Anas acuta, Linnaeus, 1758), Белка обыкновенная (Sciurius vulgaris, Linnaeus, 1758), Могильник (Aquila heliaca, Savigny, 1809), Мохноногий сыч (Aegolius funereus, Linnaeus, 1758). Наиболее экспрессивно экскурсанты реагируют на звуки, издаваемые Сойкой, в силу разнообразия имитируемых ею голосов [2].

Наряду с этим, особое внимание школьников привлекают уникальные сюжеты, полученные с камер слежения и фотоловушек (Рис. 3.). Возможность демонстрации вышеуказанных видеоматериалов возникла вследствие того, что сотрудниками Центра по изучению и охране снежного барса совместно с корейскими учеными в Восточных Саянах на вершине горы Мунку-Сардык, на высоте 3000 метров была впервые в Бурятии установлена видеоловушка. Среди попавших в кадр животных оказались одни из самых редких зверей, занесенных в Красную книгу: снежный барс (Uncia uncial Schreber); сибирский горный козел (Capra sibirica Pall.), алтайский улар (Tetraogallus altaicus Gebler) и др. Материалы, полученные с видеоловушек были переданы сотрудникам Института общей и экспериментальной биологии СО РАН и с успехом применены в обновленной экспозиции Музея БНЦ СО РАН. 
У учащихся есть возможность не только увидеть и полистать Красную книгу, но и представить, как выглядят некоторые «краснокнижные» животные и растения в реальности: Мохноногий сыч (Aegolius funereus L.), Даурский ёж (Erinaceus dauricus) (Рис. 2.), Могильник (Aquila heliaca S.), а также переведенный в бионадзорный список - Сурок монгольский (Marmota sibirica) (Рис. 6.). Редкие виды растений представлены в музее гербарными образцами Луносемянника даурского (Menispermum dauricum), Родиолы розовой (Rhodíola rosea), Орехокрыльника монгольского (Caryopteris mongholica), Гармалы чернушкообразной (Peganum nigellastrum), Солодки Уральской (Glycyrrhiza uralensis), Тонкотрубочника скального (Stenosolenium saxatile) [4].

В завершение в фоновом режиме воспроизводится клип с фотографиями животных из Красной книги России и животных с «Черных страниц» Красной книги, сопровождаемые песней «Красная книга» Олега Газманова, что способствует на наш взгляд более глубокой рефлексии аудитории [3].

Динамичному характеру лекции-экскурсии, несомненно, способствует разнообразное мультимедийное сопровождение вкупе с натурными образцами и фотоматериалами. Особую эмоциональную нагрузку несет аудиосопровождение, которое позволяет добиться необходимого воздействия на ассоциативную память экскурсантов.

Разработка лекции-экскурсии была проведена в соответствие с общепринятой экскурсионной методикой, состоящей из нескольких разделов - подготовки новой экскурсии, проведения экскурсии, послеэкскурсионной работы. В процессе подготовки новой экскурсии осуществлены ряд этапов, объединенные в несколько блоков: начальные этапы подготовки экскурсии, ключевые этапы подготовки экскурсии, текстово-документационное обеспечение экскурсионного проекта, проведение пробной экскурсии.

Содержательным стержнем экскурсии стала тема, обусловившая отбор объектов экскурсионного показа и рассказа. Была разработана концепция экскурсии; информация по теме извлекалась из литературных, изобразительных, вещественных и аудиальных источников. Экскурсионные объекты классифицированы по тематическому признаку, функциональному назначению, степени сохранности. Для оценки экскурсионных объектов использованы такие их качества, как соответствие теме экскурсии, познавательная ценность, известность, экзотичность, выразительность, акустическая среда, сохранность, месторасположение, временное ограничение показа объекта. Экскурсионный проект обеспечен необходимой документацией: паспорт объекта, контрольный и индивидуальные тексты, «портфель экскурсовода», технологические карты №№ 1, 2.

Разработанная экскурсия органично вписывается в систему экологического образования; позволяет рассказать о природоохранных организациях и исследованиях окружающей среды, а также о результатах этих исследований - официальных изданиях, содержащих описание и состоя- 
ние животных и растений, которым в большей или меньшей степени угрожает опасность исчезновения (Красной книге Международного союза охраны природы, Красной книге России, Красной книге Бурятии) (Рис. 4.). Экскурсия позволяет познакомить с редкими и исчезающими видами животных и растений Республики Бурятия, показать редкие растения и животных коллекции Музея БНЦ СО РАН, внесенных в Красную книгу Республики Бурятия.

В начале и в конце экскурсии на широкоформатном LED-телевизоре воспроизводится клип с фотографиями животных из Красной книги России и животных с «Черных страниц» Красной книги, сопровождаемые песней «Красная книга» Олега Газманова. Во время экскурсии активно используется метод показа и рассказа и метод вопросов и ответов; в экспозиционном зале размещаются скамьи и стулья, но экскурсанты периодически покидают свои места для знакомства с натурными образцами экспозиции (Рис. 5.). В качестве дополнительного эпизода, возможна организация встречи экскурсантов с научными сотрудниками Лаборатории флористики и геоботаники Института общей и экспериментальной биологии СО РАН. Содержание и длительность экскурсии-лекции варьируется соответственно возрасту: детская аудитория (средний школьный возраст 12-15 лет; старший школьный возраст 15-18 лет.), студенты (1820 лет).

Экологическая ситуация во многих районах земли, в том числе и в России, не может считаться благополучной. Экологическая ситуация в стране определяется количеством и качеством антропогенных изменений в природе, последствиями техногенного вмешательства в природу.

Необходимо стремиться к тому, чтобы сформировать у населения чувство ответственности за будущую сохранность животного и растительного мира, воспитывать чувство сопереживания за экологическое состояние региона, пропагандировать разумное и бережное отношение подрастающего поколения к природным богатствам родного края. Именно эти цели были поставлены при разработке лекции-экскурсии «Красная книга Республики Бурятия» в Музее Бурятского научного центра. Как итог по праву можно считать возрастающий спрос на проведение данной лекции-экскурсии.

\section{Примечания}

1. Бураева С. В., Васильев В. М. Специфика популяризации естественнонаучных знаний в контексте системы «Музей-школа» (из опыта работы Музея Бурятского научного центра) // Сборник научных трудов молодых ученых, аспирантов, студентов и преподавателей по результатам проведения Пятого молодежного экологического Конгресса «Северная Пальмира», 19-20 нояб. 2013 г. Санкт-Петербург. СПб. : НИЦЭБ РАН, Лингвист. центр «Тайкун», 2013. С. 136-138. 
2. Васильев В. М. Аудиовизуальная коммуникация в естественнонаучной экспозиции музея Бурятского научного центра // Современные тенденции в развитии музеев и музееведения : материалы III Всерос. науч.-практ. конф. (Новосибирск, 9-12 окт. 2017 г.) / отв. ред. В.А. Ламин [и др.]. Новосибирск, 2017. С. 201-204.

3. Васильев В. М. Красная книга Бурятии : интерактивная лекцияэкскурсия в Музее БНЦ СО РАН // Проблемы изучения, сохранения и интерпретации историко-культурного наследия Байкальского региона : материалы науч.-практ. краевед. конф., посвящ. 35-летию со дня образования Музея народов Севера Бурятии им. А.Г. Позднякова, 2016 г. с. Багдарин. Улан-Удэ, 2016. С. 39-41.

4. Васильев В. М. Экскурсия-лекция «Красная книга Республики Бурятия», как форма диалога между экскурсоводом и школьником (из опыта разработки музея БНЦ СО РАН) // Миссия музея в мультикультурном мире : Междунар. музейный форум в Казани, 8-12 сент. 2015 г : тезисы. Казань, 2015. С. 43.

5. Зубкова Т. Н. О необходимости интеграции естественнонаучного и гуманитарного подходов в экологическом образовании (из опыта создания выставочных проектов) // Труды Государственного Дарвиновского музея. М., 2007. Вып. 10. С. 276-283.

6. Красная книга Республики Бурятия. Редкие и находящиеся под угрозой исчезновения виды животных, растений и грибов. Изд. 3-е, перераб. и доп. / отв. ред. Н. М. Пронин. Улан-Удэ : Изд-во БНЦ СО РАН, $2013.688 \mathrm{c}$.

\section{References}

1. Buraeva S.V., Vasilyev V.M. Specifika populjarizacii estestvennonauchnykh znanij v kontekste sistemy «Muzej-shkola» (iz opyta raboty Muzeja Burjatskogo nauchnogo centra) [The specifics of natural science knowledge popularization in the context of "Museum-school" (from the experience of the Museum of the Buryat scientific center)] // Sbornik nauchnykh trudov molodykh uchenykh, aspirantov, studentov i prepodavatelej po rezul'tatam provedenija Pjatogo molodezhnogo ekologicheskogo Kongressa «Severnaja Pal'mira», 19-20 nojabrja 2013 g. Sankt-Peterburg [Proceedings of the $\mathrm{V}^{\text {th }}$ youth ecological Congress «The Northern Palmira» of the young scientists, post-graduates and teachers, 19-20 November 2013, SaintPetersburg]. S.-P., 2013. Pp. 136-138 [In Russ.].

2. Vasilyev V.M. Audiovizual'naja kommunikacija v estestvennonauchnoj ekspozicii muzeja Burjatskogo nauchnogo centra [Audiovisual communication in the natural science exposition of the Buryat science center Museum] // Sovremennye tendencii $v$ razvitii muzeev i muzeevedenija: mat-ly III Vseros. nauch.-prakt. konf. (Novosibirsk, 9-12 oktjabrja 2017 g.) [Modern tendencies in the development of museums and museum science: materials of the III $^{\text {rd }}$ All-Russian scient.-pract. conf. 
(Novosibirsk, October 9-12 2017) / chief editor V.A. Lamin [and others]. Novosibirsk, 2017. Pp. 201-204. [In Russ.].

3. Vasilyev V.M. Krasnaja kniga Burjatii: interaktivnaja lekcijaekskursija v Muzee BNC SO RAN [The Red book of Buryatia: interactive lecture-excursion in the Museum of the BSC SB RAS] // Problemy izuchenija, sokhranenija i interpretacii istoriko-kul'turnogo nasledija Bajkal'skogo regiona: materialy nauch.-prakt. kraevedcheskoj konferencii, posvjashchennoj 35-letiju so dnja obrazovanija Muzeja narodov Severa Burjatii im. A.G. Pozdnjakova, 2016 g. s. Bagdarin [Problems of studying, preserving and interpreting historical-cultural heritage of the Baikal region : materials of the scientific-practical conf. devoted to $35^{\text {th }}$ anniversary of the foundation of the Museum of the peoples of the North of the Republic of Buryatia named after A.G. Pozdnyakov, 2016, village Bagdarin. Ulan-Ude, 2016. Pp. 39-41 [In Russ.].

4. Vasilyev V.M. Ekskursija-lekcija «Krasnaja kniga Respubliki Burjatija», kak forma dialoga mezhdu ekskursovodom i shkol'nikom (iz opyta razrabotki muzeja BNC SO RAN) [The excursion-lecture "The Red book of the Republic of Buryatia" as a form of a dialogue between a guide and a pupil (from the experience of the development of the Museum BSC SB RAS)] // «Missija muzeja $\mathrm{v}$ mul'tikul'turnom mire»: mezhdunar. muzejnyj forum $\mathrm{v}$ Kazani», 8-12 sentjabrja $2015 \mathrm{~g}$. [Museum mission in the multicultural world : intern. museum forum in Kazan, 8-12 September 2015: abstracts]. Kazan, 2015. P. 43. [In Russ.].

5. Zubkova T.N. O neobkhodimosti integracii estestvennonauchnogo i gumanitarnogo podkhodov v ekologicheskom obrazovanii (iz opyta sozdanija vystavochnykh proektov) [About the necessity of natural science and humanitarian approaches integration in the environmental education (from the experience of creating exhibition projects)] // Trudy Gosudarstvennogo Darvinovskogo muzeja. [The works of the State Darvin museum]. M., 2007. Issue 10. Pp. 276-283. [In Russ.].

6. Krasnaja kniga Respubliki Burjatija: Redkie i nakhodjashchiesja pod ugrozoj ischeznovenija vidy zhivotnykh, rastenij i gribov [The Red book of the Republic of Buryatia: Rare and endangered species of animals, plants and fungi]. $3^{\text {rd }}$ ed., revised and enlarged. / chief ed. N.M. Pronin. Ulan-Ude, 2013. 688 s. [In Russ.]. 
Приложение 1

Рис. 1. Раздел «Красная книга Республики Бурятия»

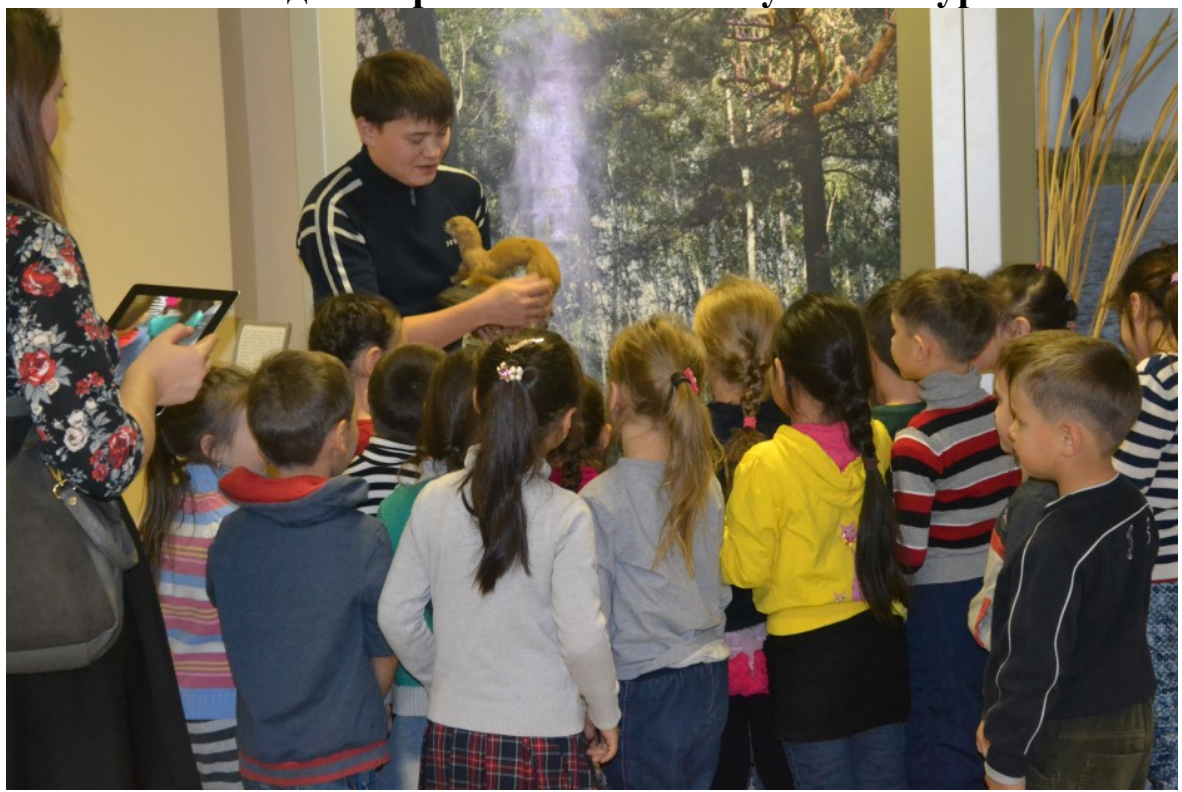

Рис. 2. Знакомство с Даурским ежом

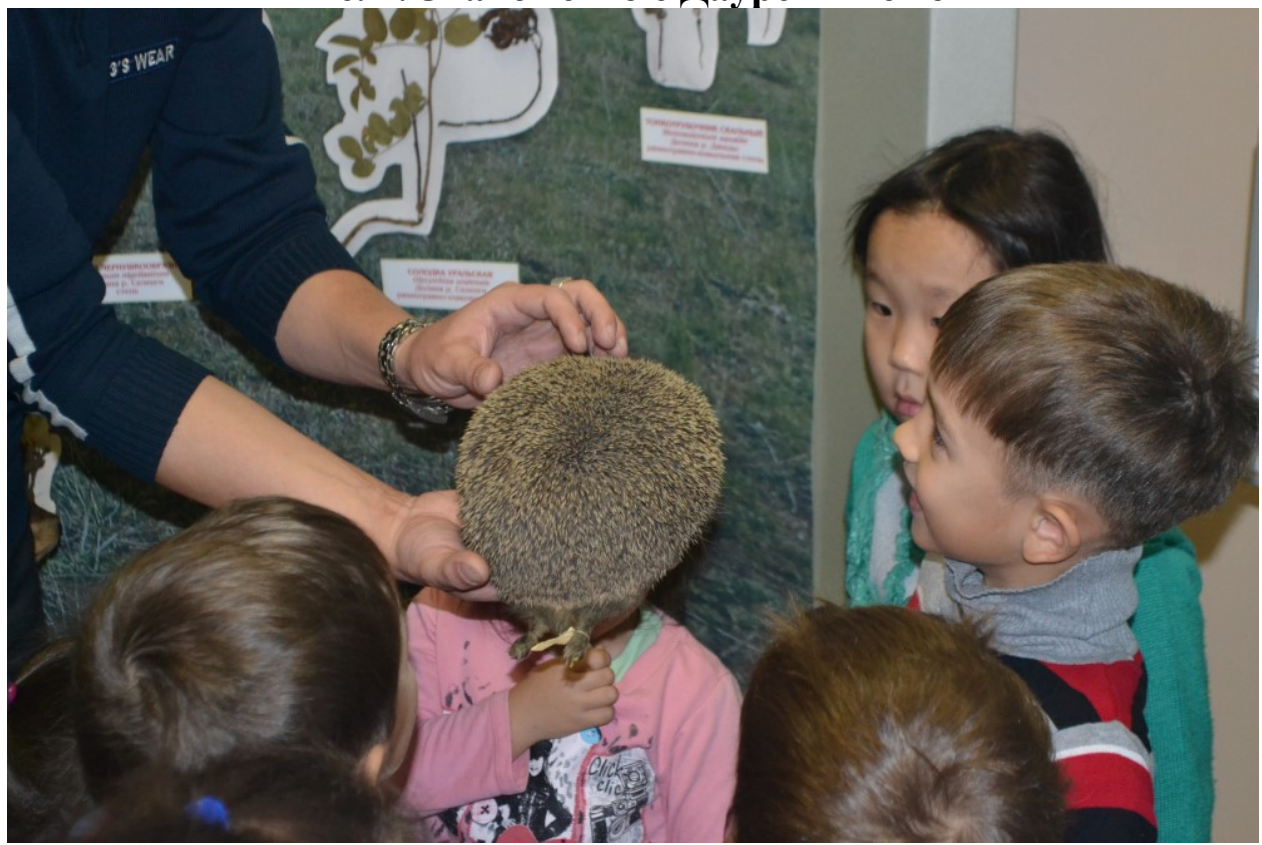


Рис. 3. Демонстрация сюжета о Снежном барсе

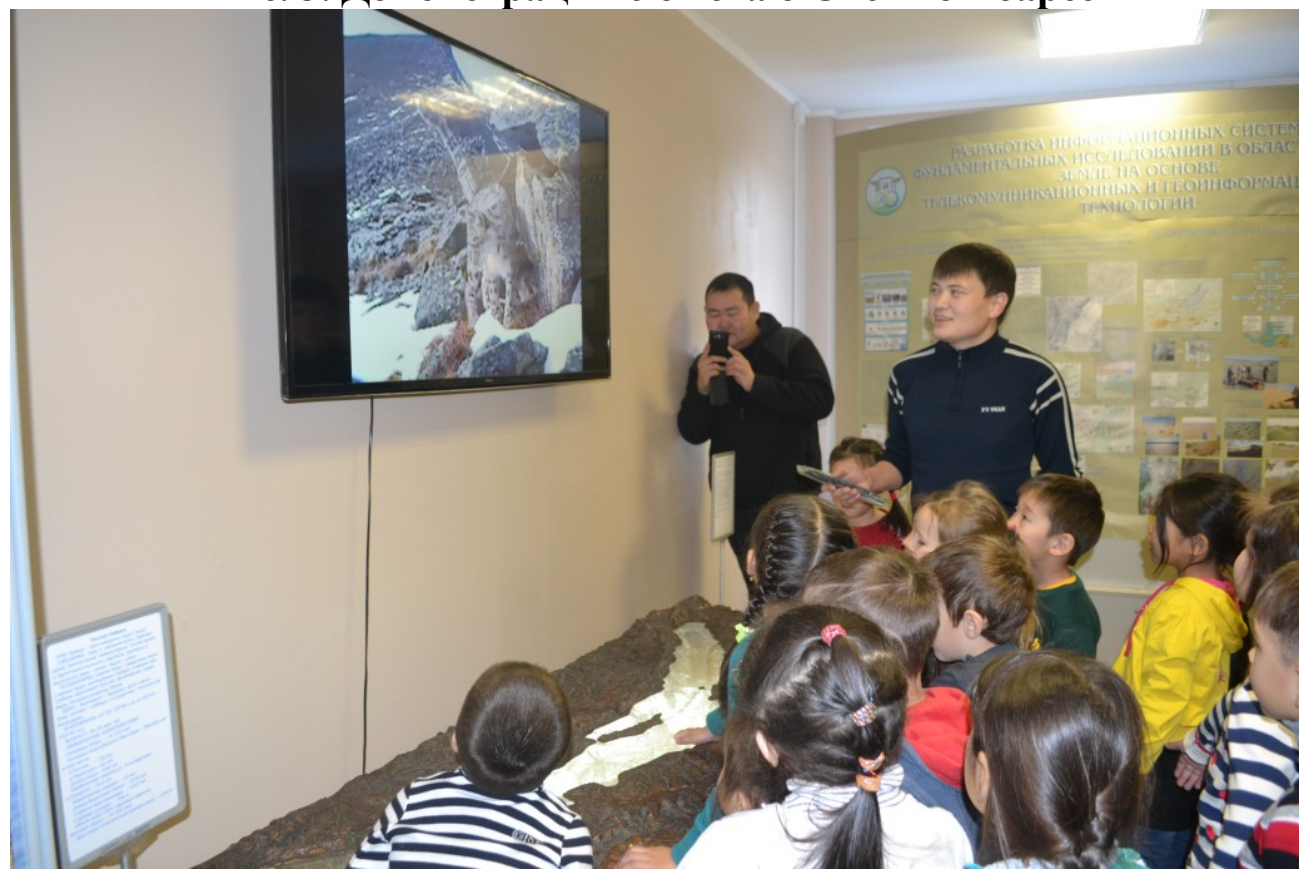

Рис. 4. Демонстрация Красной книги Республики Бурятия

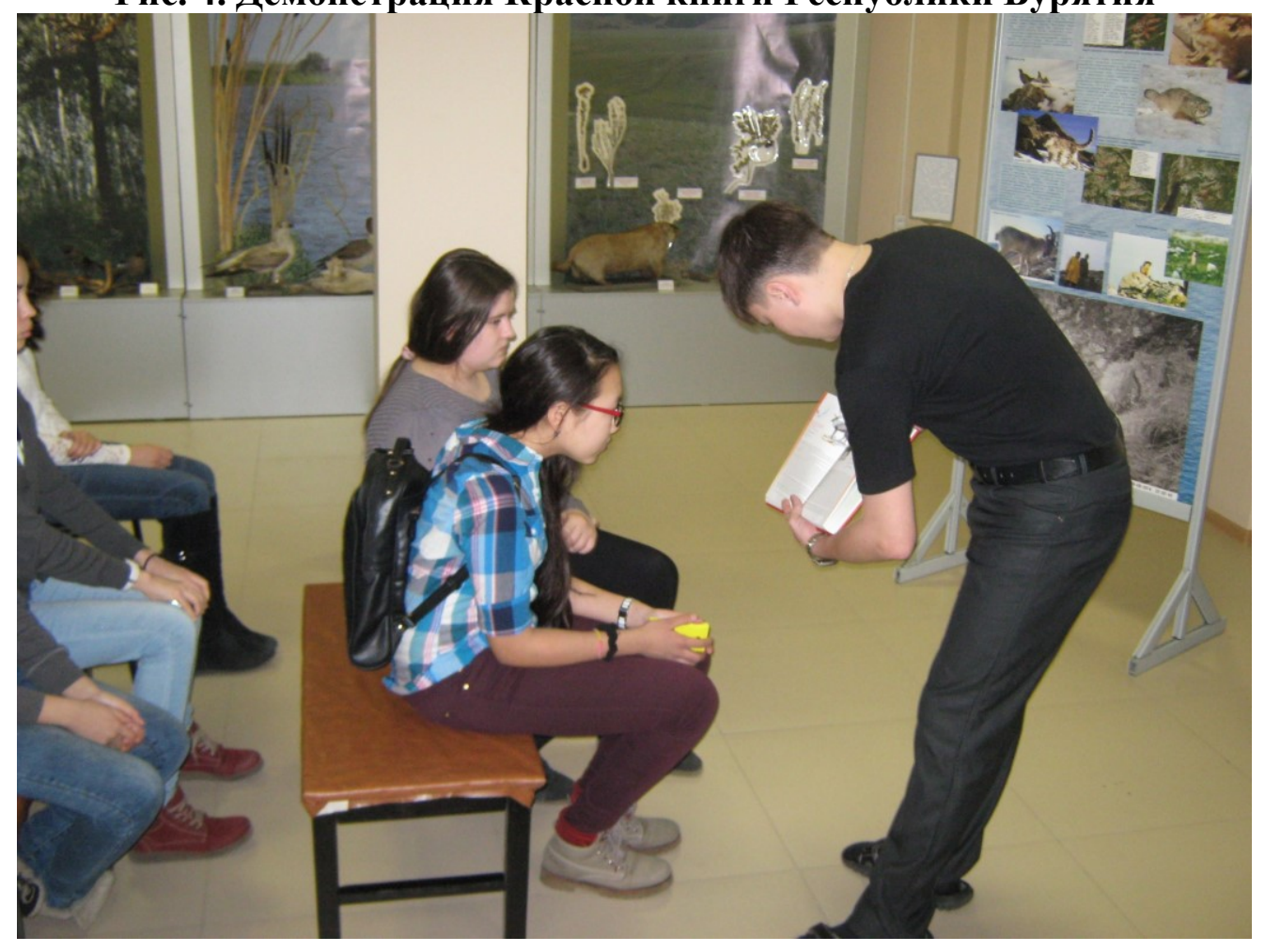


Рис. 5. Экскурсия по залу

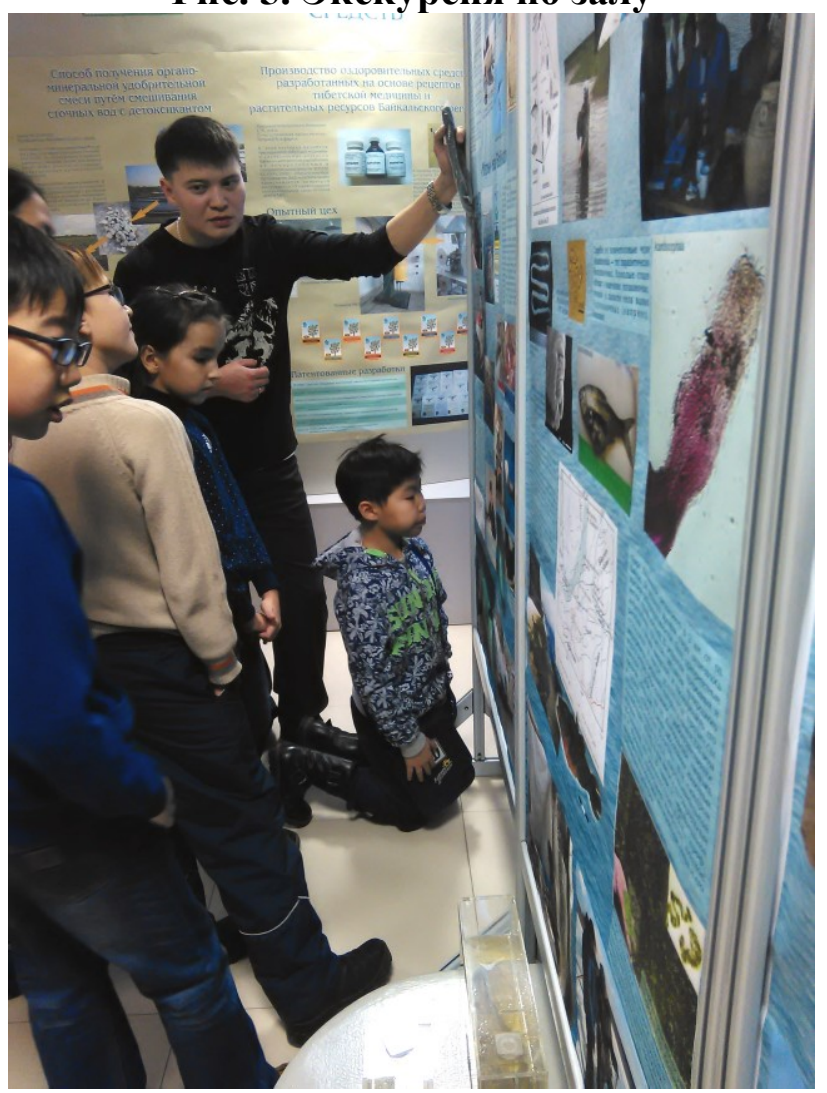

Рис. 6. После рассказа легенды о Монгольском сурке

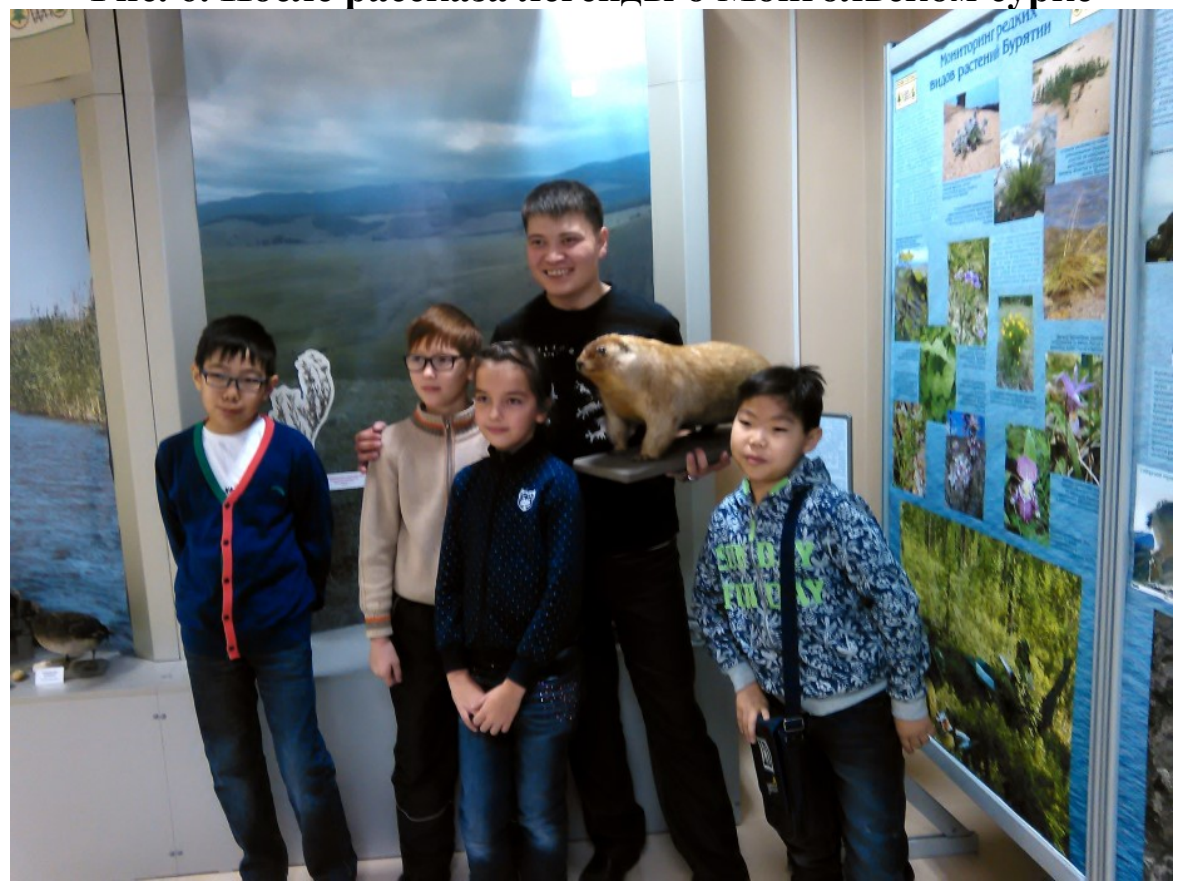




\title{
ИСКУССТВОВЕДЕНИЕ
}

\author{
DOI 10.31443/2541-8874-2019-2-10-132-137 \\ УДК 78.071.4(571.54)
}

\section{Цибудеева Н.Ц. \\ Tsibudeeva N.Ts.}

\section{НАУЧИТЬ ПОНИМАТЬ ПРЕКРАСНОЕ TO TEACH TO UNDERSTAND THE BEAUTIFUL}

В статье говорится о жизненном и творческом пути преподавателя фортепиано детской музыкальной школы №1 В.С. Соколовой (19071996), оказавшейся в республике в начале XX в. Время, отмеченное крутым сломом всех сторон политической, экономической, культурной жизни, обернулось тем, что в Бурятии, на фоне всеобщей разрухи и голода, стихийно возник очажок музыкального просвещения, который со временем разросся и дал жизнеспособные ростки в виде разветвлённой системы музыкального образования из музыкального училища (ныне колледжа искусств), а также 73-х музыкальных школ при советской власти и школ искусств.

The article tells about the life and creative work of V.S. Sokolova (1907-1996), a piano teacher of children's school of music No. 1, who came to the republic at the beginning of $\mathrm{XX}^{\text {th }}$ century, the time marked by a steep breakdown of political, economic and cultural life. At this particular time, however, despite general ruin and hunger a centre of musical enlightenment arose spontaneously. It eventually gave birth to an extensive system of musical education including the music college (now the College of Arts) as well as 73 schools of music under the Soviet regime .

Ключевые слова: свободный художник, новояз, гармонифлют, фисгармония, монпансье, керенки, контрвалюта, Транссибирская магистраль, «Синяя блуза», агитационный театр, купец, гильдия, папанинцы.

Keywords: freelance artist, newspeak, harmonic flute, harmonium, fruit drops, Kerenkas, counter currency, Trans-Siberian Railway, «Blue Blouse», agitation theater, merchant, guild, papanintsy.

Близится 100-летие со времени зарождения и становления музыкального образования в республике, которое состоится в 2020 г. и связано с именем его основоположницы Веры Дмитриевны Обыденной (18871972) [1]. Уроженка г. Витебска, она окончила в 1912 г. Петербургскую консерваторию со званием «свободный художник», согласно образовательному уставу того времени. В Верхнеудинск (тогдашнюю столицу ДВР) её занесло ветрами великих социальных потрясений, так как её мужа, предположительно подпоручика Белой армии и соратника адмирала 
А.В. Колчака, поглотил безжалостный пламень гражданской междоусобицы 1917-1922 гг.

Уже в октябре 1920 г. на ул. Троицкой (ныне Куйбышева) открылись музыкальные классы для взрослых и детей. Музыке обучались все желающие, независимо от возраста и занимались с раннего утра и до позднего вечера в единственной, отведённой для этого, комнатке. Постоянного жалования ещё не было, но руководитель правительства ДВР П.П. Постышев (1887-1939) помогает школе дровами, её оснащении инструментами и нотами. Его имя впоследствии было присвоено городскому Дому пионеров по ул. Ленина, 20.

Одной из первых учениц музыкальных классов стала Валентина Соколова (1907-1996) из Кудымкара Коми-Пермяцкого округа, семью которой сдвинул с насиженного места послереволюционный хаос. Наделённая природным наблюдательным умом, она умела учиться, впитывала в себя мельчайшие крупицы знаний и щедро делилась ими с людьми. Она живо откликалась на всё, что касалось музыки, театра, истории края и страны. События большой политики, как и суета вокруг малой, были в стороне от её жизненных интересов.

В советские времена она была носителем и живым воплощением культуры, свойственной российской дореволюционной интеллигенции. Её несколько старомодная речь с оборотами пролетарского новояза вербально и интонационно характеризовала человека другой эпохи, нечто неуловимо сходного с профессором Преображенским из к/ф «Собачье сердце» по М. Булгакову. Крайне интересный собеседник, она хорошо помнила дореволюционные названия улиц, разбиралась в особенностях застройки города, исторических памятников. На всё имела самостоятельное суждение.

Валентина многое унаследовала от мамы - довольно начитанной библиотекарши и отца - железнодорожного инженера, интересовавшегося техническими новинками и строительством в те годы Транссиба (18911905 гг.).

В родительском доме стоял гармонифлют, т.е. фисгармония - небольшой органчик, на котором одной рукой жмут на клавиши, а другой на педали для нагнетания воздуха в мехи. Самой большой бедой для девочки был отказ старших помогать в нажатии педалей, а значит, невозможность играть на инструменте.

Учиться музыке Валентина начинала в г. Сарапуле недалеко от Ижевска: овладевала игрой на фортепиано и скрипке, изучала теорию музыки, сольфеджио, музыкальную энциклопедию и т.д. В городе было отделение ИРМО (Императорского русского музыкального общества), а значит, и более или менее развитые очаги культуры. Там она впервые услышала оперу «Евгений Онегин» П. Чайковского, там выдержала испытания в музыкальную школу в присутствии преподавателя Петербургской консерватории - эстонского композитора и пианиста Артура Лембы (1885-1963). По окончании экзаменов гость дал концерт, в программе ко- 
торого значился труднейший по исполнению «революционный» этюд А. Скрябина.

... 20-е гг. XX в. отмечены в России мощным переделом власти с новыми центрами силы, ожесточённым их противостоянием и вовлечением в этот крутой водоворот разных слоёв населения. Государственная машина, рухнувшая в Петрограде, раздробилась и переместилась за Урал под знамёна лидеров, стихийно возникавших в Уфе, Екатеринбурге, Омске и т.д. Будучи сторонником мирного обывательского уклада, семья Соколовых, не разделяя ничьих убеждений, искала лучшей доли где-нибудь на Востоке.

Добравшись до Читы, решили, что Верхнеудинск лучше расположен вдоль магистрали и поехали назад. Это отвечало источникам середины XIX в., где значилось, что наш городок на Селенге и Уде самый красивый из уездных в Сибири [2].

Уже осенью 13-летняя Валентина пошла в музыкальную школу и оказалась единственной среди 70-ти её воспитанников, кто останется со своим педагогом навсегда, став её единомышленником, сподвижницей, коллегой, разделяя общие производственные и житейские радости и неурядицы.

C первых дней учёбы она начинает давать уроки, сначала частные, т.к. семья нуждалась в помощи, а нечленов профсоюза на работу не принимали. Купеческие семьи, коих в городе было немало, занятия оплачивали, когда катушками ниток, когда баночками монпансье (леденцами). Иногда рассчитывались казначейскими билетами, среди которых были керенки, американские, царские, контрвалюта.

Люди, изведавшие участь социального или профессионального изгоя, умеют сочувствовать друг другу. Так и Вера Дмитриевна, понимавшая, что новенькая нуждается в членстве в профсоюзах, а такой билет могла дать работа с общественниками-синеблузниками.

Местный филиал «Синей блузы» находился в подвале Дворца Труда (ныне - здание музея Природы и театра «Ульгэр»). Отвечая задачам времени, этот вид художественной самодеятельности, работал на агитацию установившейся власти и привлекал на её сторону ещё не определившиеся, колеблющиеся народные массы. Основой его сюжетов были международные события на злобу дня, производственная и бытовая тематика, монтировавшиеся по подобию «живой газеты». Синеблузники вели активную общественную жизнь, участвуя в строительстве моста над Селенгой в районе Кабанска, в торжественном открытии Дома отдыха на Верхней Берёзовке среди змей и другой лесной живности. Долго в архиве Валентины Сергеевны хранилась афиша: «Добро пожаловать!» с программой выступлений драматических актёров в сопровождении рояля в её исполнении. Были у них замечательные коллективы - хор и оркестр народных инструментов, которые вечерами репетировали, а днём выступали. 
Наша героиня рассказывала, что в проектировании города участвовал губернский архитектор А.И. Лосев, назвавший ныне Коммунистическую улицу Лосевской по имени купца 2-ой гильдии, переименованную затем в Юного коммунара, затем - Сталинскую. На фасаде магазина «Ткани» (угол б. Большой и б. Базарной) до сих пор остались две ниши в человеческий рост от уличных зеркал, в которые мог посмотреться прохожий. Балконы зданий купцов Второвых украшались по всей Сибири резными чугунными решётками. В доме купца С.И. Розенштейна (здание факультета иностранных языков БГУ), где в 20-е гг. располагалась частная труппа, выступал тенор с итальянской постановкой голоса, устраивались выставки местных художников-футуристов. На месте Геологического музея находился Дом науки, искусства и литературы (ДНИЛ), перед которым в дни пролетарских праздников выставлялись струганные столы с лавками - угощали сладостями и хлебом. По подписному листу собирали всем городом деньги на памятник борцам Революции, который находится на ул. Кирова (бывшая Базарная - Коммунальная). В посёлке Ленина (на Верхней Берёзовке) находилась частновладельческая заимка купца Железникова. Ещё долго оставались мельничные жернова и медные пластины с именами, выгравированными на их могилах по дорожке к ручью. Она не вспоминала, а продолжала оставаться в том времени, где прошла лучшая часть её жизни.

В 1926 г. Валентина Сергеевна поступает в Томское музыкальное училище по направлению РАБИСа (профсоюз работников искусства). Там она учится у Феофании Борисовны Тютрюмовой - невысокой кудрявой женщины с абсолютным слухом, внезапно исчезнувшей в 1937 г. «Важно привить человеку любовь к музыке. Она рано или поздно проявится в виде понимания этого вида искусства или тяги к нему», говорила педагог. Этот наказ старалась выполнить воспитанница и верно ему следовала на протяжении своего долгого педагогического пути.

Окончив суз по трём специальностям: фортепиано, дошкольное воспитание и клубное дело, Валентина Сергеевна даёт публичные концерты, работает тапёром немого кино. А это далеко непросто, т.к. требует знания огромного объёма музыки, используемой в зависимости от той или иной драматургической ситуации. Произведений для озвучивания фильмов набирается у неё на два сеанса. Пробуя разные виды деятельности, она постоянно ищет, чему отдать предпочтение.

Однако пересиливает жажда к совершенству, и в 1934 году она отправляется в Ленинград, чтобы брать уроки у консерваторских педагогов. А чтобы их оплачивать, работает в музыкальной школе. Интересуется, чем живут обе столицы, уезжает в Москву.

Сильнейшее впечатление на Валентину Сергеевну произвела постановка во МХАТе пьесы «Дни Турбиных» М. Булгакова («Как же любили Россию царские офицеры, и что им пришлось пережить в эту жуткую полосу всеобщего одичания!»). В филармонических залах слушает выступления признанных пианистов Якова Флиэра, Эмиля Гилельса, «Хро- 
матическую фантазию и фугу» в исполнении Марии Юдиной, американскую негритянскую певицу Мариам Андерсон. Встречается с героическими покорителями Арктики в 1937-1938 гг. - папанинцами и хранит шёлковый шнур, которым крепились их палатки. В театре Вс. Мейерхольда застаёт знаменитую Зинаиду Райх в «Даме с камелиями» по А. Дюма.

Но республика нуждается в специалистах, и Валентину Сергеевну отзывают. По возвращении в Улан-Удэ она работает в музыкальном училище и в детских садах. Приходит в родную ДМШ №1, ставшей теперь 7леткой с профессиональным уклоном.

Полученные знания стали настоящей базой для преподавания. Теперь она передаёт их детям. Первые шаги на этом поприще делались под наблюдением Веры Дмитриевны, заметившей в ней педагогическую жилку, умение вдумчиво и тонко работать с учениками.

«Научить ребёнка не только уметь играть на инструменте, но и любить музыку, понимать прекрасное - такую цель я ставлю, начиная заниматься с каждым новичком. Стараюсь внушить ребёнку с первого его прикосновения к фортепиано, что звук должен обладать певческими качествами», - писала мама Риты Елисеевой, одной из её лучших учениц, окончившей после Валентины Сергеевны Улан-Удэнское музыкальное училище и Уральскую консерваторию [3].

Поскольку музыкальное искусство отличается большим консерватизмом по сравнению с остальными, то людям из этого мира свойственна некоторая старомодность во взглядах, в манерах, одежде. Когда поведение юных музыкантов противоречило её пониманию хорошего тона, она беззлобно пеняла им по поводу щёлканья семечек на людях. Отработав по расписанию, могла зайти в соседний класс и терпеливо разъяснять, что пианино следует закрывать. И не дай Бог, если заставала посиделки на крышке инструмента! Тогда беседа затягивалась до полного взаимопонимания, полного признания ошибок.

Такое же взаимопонимание достигалось контактами с семьями учеников, контролем на дому во время каникул, беседой с родителями за чашкой чая. Об этих эпизодах говорит заслуженный работник культуры РФ и РБ С.Б. Грешилова, директор МГЛ им. Д.Д. Аюшеева: «В моей душе остались тёплые воспоминания о Валентине Сергеевне - в высшей степени добром и ласковом человеке. Я всегда буду благодарна тем интересным занятиям, которые многому меня научили и которым я обязана своим сегодняшним положением».

В свою очередь Валентина Сергеевна с любовью и вниманием следила за успехами своих питомцев, о чём свидетельствуют письма от Евгения Ржанова (1938) - лауреата Международного конкурса пианистов им. королевы Елизаветы в Брюсселе. Оказавшись с родителями в нашем городе в эвакуации, он четыре года здесь обучался. Затем продолжил учёбу в Киевской спецшколе-десятилетке, затем в Московской консерватории и аспирантуре у Я.В. Флиэра (1912-1977) и Л.Н. Власенко (19281996). Став доцентом Киевской консерватории, он много концертировал 
по стране и за рубежом. Программу гастрольной поездки по Португалии 1977 г. с исполнением европейской классики и украинских композиторов Валентина Сергеевна хранила в своём архиве. И как эстафету передала своей ученице Ольге Бард, с семьёй которой дружила.

Привычка слушать «живую» музыку привела Валентину Сергеевну в оперный театр на выступление Святослава Рихтера в его последнем концертном турне по Сибири и Дальнему Востоку. «Я здесь самый старый музыкальный работник и счастлива, что дожила до того времени, что услышала Вас», выразила она своё отношение к величайшему пианисту современности в этой знаменательной встрече за кулисами [4].

\section{Примечания}

1. Цибудеева Н. Ц. Тропинка первая моя, лети от школьного порога... : творческие портреты преподавателей музыкальных школ г. УланУдэ. Улан-Удэ : Улзы, 2003. 44 c.

2. Гурьянов В. К., Гурьянов М. В. Верхнеудинск XVII - начала XX века. Улицы, городские усадьбы и их обитатели. Улан-Удэ, 2012. 224 с.

3. Елисеева Г. Войти в мир музыки // Правда Бурятии. 1977. 12 нояб.

4. Чемберджи В. Дороги Святослава Рихтера // Советская культура. 1986. 16 дек.

\section{References}

1. Tsibudeeva N.Ts. Tropinka pervaja moja, leti ot shkol'nogo poroga ...: tvorcheskie portrety prepodavatelej muzykal'nykh shkol g. Ulan-Ude [My first footpath, fly away from the school threshold...: creative portraits of the teachers of Ulan-Ude schools of music]. Ulan-Ude, 2003. 44 p. [In Russ.].

2. Guryanov V.K., Guryanov M.V. Verkhneudinsk XVII - nachala XX veka. Ulicy, gorodskie usad'by $\mathrm{i}$ ikh obitateli [Verkhneudinsk in the XVII ${ }^{\text {th }}$ at the beginning of the $\mathrm{XX}^{\text {th }}$ centuries. Streets, estates and their inhabitants]. Ulan-Ude, 2012. $224 \mathrm{p}$.

3. Eliseeva G. Voiti v mir muzyki [Enter the world of music] // Pravda Burjatii [Pravda of Buryatia]. 12 November. 1977.

4. Chemberdzhi V. Dorogi Svjatoslava Rikhtera [Ways of Svyatoslav Rikhter] // Sovetskaja Kul'tura [Soviet Culture]. 16 December. 1986. 
УДК 339.138

\section{Цыренжапова Л. М.}

Tsyrenzhapova L. M.

\section{МАРКЕТИНГОВАЯ ПОЛИТИКА АРТ-МЕНЕДЖМЕНТА В АРТ-ИНДУСТРИИ \\ MARKETING POLICY OF ART-MANAGEMENT IN THE ART-INDUSTRY}

Изучение потребителей важно для эффективной работы учреждения искусства, так как предлагаются необычные специфические, художественные продукты нематериальной ценности.

The study of consumers is important for the effective work of an art institution as it offers unusual specific artistic products of intangible value.

Ключевые слова: маркетинг, психографика, сегментация, лояльность, потребители, арт-менеджмент, арт-индустрия, арт-рынок, потребительское поведение.

Keywords: marketing, psychographics, segmentation, loyalty, consumers, art-management, art-industry, art-market, consumer behavior.

Научно-технический прогресс вносит огромные структурные изменения во все сферы жизнедеятельности человека. Общество нового тысячелетия полностью зависит от технологических новинок, остро реагируя на потребительский рынок. Современный художественный мир меняется в зависимости от технологического предложения продуктов времени. Вкусы и предпочтения потребляемого продукта современного общества формируются и развиваются благодаря маркетинговым установкам, новым разработкам маркетинговых инструментов.

Маркетинговая политика крупного бизнеса агрессивного завоевания сознания потребителей вышла на новый уровень развития по внедрению инноваций в продвижении продукции, в рекламных войнах по завоеванию новых рынков сбыта товаров и услуг. Если в прошлом столетие маркетинговые технологии были направлены на захват сегмента промышленных и продовольственных рынков, третье тысячелетие ознаменовало борьбу за нишу творческого продукта на рынке мировой арт-индустрии.

Экономические и управленческие функции в искусстве гармоничным образом поставили в единый ряд мир ощущений, осязания, зрительного, эстетического удовольствия, радости творчества с категорией продаж и финансовых потоков. Финансы, экономика и художественная область стали главными партнерами на рынке потребительского сознания творческого продукта. Бизнес осознал, что борьба за конкурентоспособ- 
ность на потребительском рынке, за потребителя, начинается с культуры и искусства.

Чтобы закрепиться и отстоять свою нишу рынка, а тем более получить долю рынка на новом направлении, необходимо использовать маркетинговые инструменты, пересмотреть старые подходы создания имиджа и лояльности компании, обратившись к искусству. Через стратегическую политику взаимодействия экономической системы и творчества создается новое направление в бизнесе арт-индустрия. С приходом нового рынка арт-бизнеса, наблюдаем появление новых профессий, рожденных жизненной необходимостью.

Творчество и бизнес открыли путь креативным профессиям в артиндустрии: импресарио, концертный промоутер, имиджмейкер, концертный агент, клипмейкер, продюсер, тур - менеджер - роуд менеджер, персонал - менеджер - личный менеджер артиста или творческого коллектива, бизнес-менеджер, продакшн-менеджер. Это не полный список нового плана специалистов, работающих на рынке творческих услуг, по созданию художественных продуктов. Развитие художественной индустрии невозможно представить без финансовой составляющей арт-бизнеса, базирующейся в арт-менеджменте на основах правовых и трудовых договорных отношениях между арт-менеджментом и искусством, как двух основных игроков арт-индустрии.

Новые профессии в арт-индустрии, специалисты в определенной области организации всех этапов создания продукта, способны обеспечить эффективное функционирование учреждений театральной, музыкальной, художественной сферы деятельности. В обязанность профессионалов арт-индустрии входит организация реализации шоу-проектов различных масштабов и технической сложности.

Проведение культурных мероприятий, независимо от массовости, масштабности зрительской аудитории, сопряжены с соблюдением меры безопасности. Поэтому арт-специалисты обязаны владеть обширным запасом знаний и практическими навыками в различных областях арт-индустрии, в соответствие с требованиями современного мира. Современные технологии ворвались в концертные залы, стали неотъемлемой частью развития нового искусства.

Проведение массовых шоу-мероприятий, рассчитанных на расширение зоны зрительского охвата, повлекло за собой необходимость модернизации площадей концертного пространства. В связи с этим многие концертные залы устарели как морально, так и технически. Расширение концертного пространства в ногу со временем перемен потребовало прибегнуть к техническому переоснащению залов, помещений учреждений искусства и культуры.

Появилась возможность оснащения достижениями современного технического прогресса механизмами машинерии, усилить функционирование театров, концертных залов лазерными, компьютерными и прочими техническими новинками. Чтобы удержать зрительскую аудиторию про- 
шлых поколений, учреждениям искусства необходимо работать профессионально и стабильно предоставлять качественные художественные продукты искусства, имея в репертуаре шедевры мировой классики, выдающихся солистов, профессиональный оркестр, нормальный фонд финансирования проектов.

Другая ситуация с целевой аудиторией поколения Y, зрителей рожденных в 80-90-е годы, которые в основной массе полностью отличаются безразличием к высокому искусству, предпочитая «легкие» развлечения классическому искусству. Поэтому перед арт-менеджментом поставлена серьезная задача «выращивания», «прикормка» целой возрастной категории общественного социума, нынче потерянного для рынка арт-индустрии. В современных экономических взаимоотношениях творчество - арт - бизнес - экономика - финансы, внедрение методов технологий спонсоринга и фандрайзинга имеют важные элементы эффективности развития учреждений искусства, активного продвижения значимых проектов художественного творчества, в основе которых непосредственное финансовое участиепринимают представители поколения Ү.

Видоизменение целевой зрительской аудитории сказывается на продажах билетов в учреждениях искусства и культуры. Арт-менеджменту необходимо менять стратегию завоевания потребительского рынка нематериальных услуг, перестраивать в первую очередь тактику маркетинговой политики продажи творческого продукта обществу. Необходимость изменения подходов в использовании маркетинговых технологий для продвижения творческого продукта на рынок арт-индустрии продиктована резким снижением продажи билетов, активный доступ к интернет-ресурсам, переориентация зрительской аудитории на большее доступный сектор развлечений. Применяя маркетинговые инструменты арт-менеджмент должен получить лояльность потребителей творческого продукта, создавая положительный имидж учреждения через торговый брэнд предприятия искусства, предлагая уникальную марку и легко запоминающийся логотип художественного товара.

Для устойчивого роста предприятия, маркетинговому отделу учреждения искусства необходимо постоянно изучать, анализировать потребителя мероприятий, разрабатывать плановые мероприятия по социологическому опросу населения. Изучение потребителей важно для эффективной работы учреждения искусства, так как предлагаются необычные специфические, художественные продукты, нематериальной ценности. Соответственно и потребители творческого продукта арт-индустрии необычные посетители, которые намного образованнее, требовательнее массового обычного потребителя. Сегментирование творческого потребителя является важной задачей для маркетингового отдела учреждения искусства.

При изучении потребителей творческого продукта необходимо применить подходы по сегментированию зрителей научными исследованиями методики определения характеристик потребителей, имеющих оп- 
ределенную реакцию на товар или услугу. Объяснение и предсказание потребительского поведения, как практическое применение поведенческих и социальных наук к маркетинговому исследованию - это направление в прикладном маркетинге собрало научно-практические навыки в Психографике. Наука оценки действий человека, исходя из его личностных черт характера, поможет определить количественные показатели характеристики образа жизни человека, поведение в быту, работе, отдыхе, используемые в ходе маркетингового анализа. Психографика через анализ личностных качеств - уверенность в себе, лидерство, общительность, настойчивость, застенчивость и т.П., даст объяснения реакции жизненных моделей потребителей на потребление творческого продукта.

Маркетинговые исследования потребительского поведения помимо индивидуальных личностных черт, при сегментировании потребителей арт-индустрии с учетом демографических данных потребителя: доход, возраст, образование, место проживания, социальный статус, семейное положение и т.д., могут прибегнуть к методике определения сегментирования потребителей, взяв за основу результаты научного исследования ученых Барри Гантера и Адрианом Фернхама [1]. Из классификационной таблицы «Сегментация потребителей», «консерваторы» по отношению к продукту, которые в основной массе имеют непосредственное отношение к искусству, либо являются любителями, в частности, оперы и балета и составляют 16\% от общего процента изученных потребителей нематериальных ценностей. Процент невелик, но ведь в сегментирование потребителей художественного продукта попадает 38\% «богатых, образованных, ориентированных на элитарный досуг». Именно эти проценты возможно и есть тот потенциал зрительского поля в арт-индустрии.

Несмотря на то, что психографический подход имеет больше описательный характер исследования сегментации потребителей, для изучения потребительского рынка арт-индустрии он подходит определенно, так как именно психографические разработки в свое время помогли активному развитию учреждениям культуры Европы.

Выстраивая правильно взятую стратегическую линию на закрепление приверженности постоянной зрительской аудитории, учреждение искусства тем самым построит фундамент стабильного объема продаж художественного продукта. Потому что результаты творческого труда коллектива в конечном итоге определяют успешность организации, мотивируя персонал предприятия на развитие творческого потенциала. Лояльность зрителя, который на протяжении длительного времени будет преданным потребителем творческого продукта предприятия, необходимо завоевать раз и навсегда, постоянно поощрять различными маркетинговыми акциями: скидки, возможность выбрать лучшие места, бесплатная буклетная продукция и прочее.

Абсолютная лояльность, абсолютный потребитель, «верный» зритель и почитатель избранного единожды одного солиста или творческий коллектив, не сойдет с дистанции до последнего вздоха, увлекая своим 
вдохновенным почитанием своего кумира художественного продукта всех, кто напрямую или косвенным образом находится в окружении с ним. Абсолютных лояльных приверженцев в настоящий период развития арт-индустрии мало, поэтому необходимо выявлять и поощрять данный сегмент зрительской аудитории. Абсолютные лояльные зрители это прогрессивная часть потребительского сегмента ценителей художественных продуктов арт-рынка искусства.

За уникальными, абсолютными лидерами, поклонниками приверженности определенных солистов, жанра в искусстве, устремляются зрители, которые привлечены именно страстными поклонниками духовного брэнда высокохудожественного продукта арт-индустрии. «Верность» зрительской аудитории выражается в отношение одного жанра, исполнителя, солиста, художника, или еще какого-то направления художественного продукта. Этот вид потребительской лояльности достоин высших похвал, потому что на протяжении всего жизненного цикла продукта, никогда этот тип потребительского предпочтения, потребительского спроса не покинет раз и навсегда полюбившийся художественный продукт на рынке арт-индустрии.

Приглашенные однажды, возможно, за компанию, эта целевая аудитория постепенно втягивается в художественный процесс потребления высокохудожественного продукта искусства. Постепенно, от спектакля к спектаклю, воспитывается художественный вкус, проявляются ростки проявления интереса к высокому искусству, так зарождается класс относительно лояльного потребителя продукта искусства, впоследствии возможно переходящие в разряд абсолютной лояльности потребления художественного продукта или услуги арт-индустрии.

Отсутствие лояльности в предпочтении потребления художественного продукта говорит о «болезни» общественного сознания, потери правильной ориентации этноса, изменение нравственных ориентиров взаимоотношения внутри семейного уклада и общества в целом. С изменениями финансово-экономических отношений в обществе этот вид потребительской лояльности встречается очень редко, но в перестроечный период имел значительное проявление в обществе, когда распадались целые сельские поселения, народ терял жизненную ориентацию, теряя смысл дальнейшего существования, рушилась не только духовная основа мироздания, но и сама жизнь человека. В упомянутые «забытые» годы население республики металось от одного способа выживания к другому, о какой-либо лояльности потребительского предпочтения не могло быть и речи, ввиду полного отсутствия лояльности потребительского спроса определенной продукции. Народ хотел просто выжить физически, было не до высокого искусства.

Относительный вид потребительской лояльности продукта не устойчивый, но при правильной маркетинговой стратегии возможен переход в абсолютный тип лояльности потребителей - зрителей учреждений искусства. Если отработать в данном направлении по завоеванию лояль- 
ности потребителя, повысится процент посещаемости учреждения искусства, повышение доходности мероприятий, увеличится оборот деятельности предприятия, что будет доказывать эффективность деятельности учреждения искусства.

Маркетинг арт-искусства специфическая отрасль, направленная на предложение продажи разработанного специфического продукта нематериальной ценности, при потреблении которого он не теряет смысл, не несет материальный ущерб, а наоборот становится лучше, ярче, мотивируя создателей на еще большее творческое отношение к своей деятельности. Поэтому маркетинговые инструменты, как реклама, мерчендайзинг, промоушн-акции, прочно вошедшие в повседневную жизнь арт-индустрии, гармонично приживаются в художественном мире искусства, позволяя творческий процесс улучшить для привлечения большего чила потребителей.

\section{Примечания}

1. Гантер Б., Фернхам А. Типы потребителей: введение в психографику. СПб. : Питер, 2001.

\section{References}

1. Gunter B., Furnham A. Tipy potrebitelej: vvedenije v psikhografiku [Types of consumers: an introduction to psychographics]. S.-P. 2001 [In Russ.]. 


\section{ОБРАЗОВАНИЕ В СФЕРЕ КУЛЬТУРЫ И ИСКУССТВА}

DOI 10.31443/2541-8874-2019-2-10-144-147

УДК 001:1

Дандарон М. Б., Замоева Е. К.

Dandaron M.B., Zamoeva Ye.K.

\section{РОЛЬ НАУКИ В СОВРЕМЕННОМ ОБРАЗОВАНИИ THE ROLE OF SCIENCE IN MODERN EDUCATION}

В статье освещается роль изучения науки и философии науки в современном образовании и формировании личности. Проанализирована роль изучения истории и методологии науки в формировании общей картины мира и мировоззрении. Подчеркнут поворот в образовании от экономической и технической ориентации на гуманитарную, экологическую и духовную составляющую образования.

The article highlights the role of the science study and philosophy of science in modern education and personality formation. The role of studying the history and methodology of science in shaping the overall picture of the world and outlook is analyzed. The shift in education from the economic and technical orientation to the humanitarian, ecological and spiritual components of education is emphasized.

Ключевые слова: образование, наука, философия науки, методология, парадигма, ценности, культура, гипотеза, истина, эксперимент, доказательство.

Keywords: education, science, philosophy of science, methodology, paradigm, values, culture, hypothesis, truth, experiment, proof.

В современном высшем образовании на уровнях бакалавриата, магистратуры введена дисциплина "История и методология науки", в аспирантуре "Философия науки". Образование - это многокомпонентный целостный процесс, который должен служить интересам общества. Главная задача состоит в формировании современного типа личности. При этом процесс не может представлять собой простую передачу тех или иных знаний. "Это процесс окультуривания, возделывания личности учащегося" [1, с. 46]. Процесс образования объединяет в себе и обучение и воспитание, направлен на приобщение к базовым ценностям культуры. В процессе образования идет необходимая подготовка личности к выполнению социальных и профессиональных задач.

Образование - это интегративный процесс, который включает и обучение, и передачу и сохранение традиций, а также это творческий процесс, предполагающий эвристическую и творческую деятельность. Процесс образования длится непрерывно, включает в себя как образова- 
ние в учебных заведениях, так и самообразование в течение всей жизни человека.

Система образования опирается на науку. Новые достижения, открытия, изменения в науке диктуют необходимость внесения изменений в учебные планы. В свою очередь повышения качества и уровня образовательной подготовки напрямую влияет на развитие науки, техники, современных технологий.

Не стоит отодвигать на второй план гуманитарную составляющую образовательного процесса. Это ориентация на толерантность, на грамотные межкультурные, межконфессиональные взаимодействия, а также на духовное содержание личности.

Слово "наука" - означает научение знанию. Наука в ее современном виде, экспериментальная, доказательная, изменила жизнь человечества коренным образом. Она дает возможность решать человеку трудные задачи, обеспечивает информацией, жизнь человека во многом зависит от научных открытий. Наука работает с фактами об окружающем нас мире, полученными в ходе опытов, экспериментов и наблюдений. Наука дает конкретные знания о чем-либо. Наука постоянно ищет и предлагает способы подтверждения истинности и достоверности научных открытий. Начиная с XVII века таким критерием становится экспериментальная проверка научных гипотез. Причем эксперимент должен быть объективным и повторяемым. Это дает возможность отсекать субъективные неподтвержденные представления об окружающей действительности.

Чем же занимается философия науки? Философия науки определяет границу между истинным и ложным знанием. Изучает принципы и методы, на основе которых ученые выдвигают гипотезы и истолковывают факты, исследует процесс развития науки. Философия науки рассматривает внутреннее, логическое функционирование научного механизма. Определяет роль теории познания в выявлении соотношения ощущений человека с реальностью. Исследует влияние науки на этическую сторону человеческих взаимоотношений.

Американский философ Мел Томсон [2, с. 13], рассматривая связи между философией и наукой, определяет два проблемных вопроса:

1. Существуют ли такие аспекты реальности, которые не способна объяснить наука, но может истолковать философия?

2. Если философия и наука имеют дело с одним и тем же объектом исследования, то каким образом философия дополняет то, что в состоянии нам сказать о нем наука?

На наш взгляд, в целом философия науки представляет собой область общей философии, изучающей научные методы для выдвижения гипотез и формулирования законов учеными. Но ученые в своей деятельности занимаются кругом конкретных интересов, ограниченных проблемами окружающего мира, природы, техники, технологий. Философы ищут единые принципы в науке, стремятся нарисовать общую картину мира, в которой обязательно учитывается присутствие человека. Если 
наука опирается на строгую доказательность о подлинности научного утверждения, то человек из картины мира должен был бы быть исключен. Наука выстроила аргументацию на том, что любые методы изучения реальности, не получившие статуса научных, не должны учитываться в описании картины мира, так как они крайне субъективны. К таким способам описания мира относятся все виды искусства, духовные практики и учения, личные эмоциональные оценочные суждения. Возникает вопрос: а как же сам ученый-исследователь? Куда поместить его в этой строгой научной картине мира.

Здесь необходим краткий экскурс в историю науки. Известно, что до XVII века весь длительный период называют "донаучным периодом". Начиная с XVII века, в Новое время в Европе идет становление современной науки, которая, наконец, выработала основной критерий научности экспериментальная проверка гипотез и утверждений. XVII-XIX вв. это время расцвета классической науки, жесткой линейности и однозначности, в том числе критериев истинности в науке.

С самого начала XX века с бурным ростом экспериментальной физики, атомной физики, квантовой механики начинается пересмотр принципов, методологий в науке. Это ознаменовало возникновение новой науки - неклассической. Одним из важнейших принципов неклассической науки становится принцип неопределенностей Гейзенберга, в котором говорится, что субъект-исследователь всегда влияет на результат исследования, уже только благодаря своему присутствию, он изменяет ход событий, который без его присутствия мог иметь другой результат. Этот принцип имеет широкую экстраполяцию не только в исследованиях физики микромира, но и в любых естественнонаучных, гуманитарных и социальных исследованиях. Таким образом, неклассическая наука уже допускает непредвиденное влияние человека, субъекта-исследователя на текущий ход событий, на достоверность исследования реальности.

Последняя четверть ХХ в. считается точкой отсчета постнеклассической науки. Методологическими основаниями становятся исследования в области синергетики. Это исследования процессов в сложных открытых системах, которые находятся в постоянном взаимодействии с внешней средой, которые подвергаются флуктуациям и случайным непредвиденным воздействиям. В результате которых система из критической точки бифуркации внезапно скачком может оказаться в совершенно новом непохожем на прежнее состоянии. Постнеклассическая наука радикально отходит от жесткой линейности классической науки, и утверждает, что нельзя полностью игнорировать фактор случайностей и незначительных внешних воздействий на систему. Возможно, задача современных научных технологий заключается в том, чтобы уметь рассчитать и учесть непредвиденные обстоятельства, чтобы иметь нужный результат с заранее заданными свойствами.

Таким образом, философия науки отводит важное место человеку в исследовании реальности. Именно человек познает реальность, опреде- 
ляет критерии истинности, делает выбор между теориями, по мере развития науки, меняет теории и представления о мире. Выдвигая теории, ученые сталкиваются с проблемами языка: как описать явление, как быть правильно понятым? Философия науки связана с мировоззренческими проблемами (общая картина мира), с проблемами познания - гносеологией, с семиотикой. Она объясняет смысл практического приложения научных достижений.

В образовательном процессе философия науки выполняет несколько функций. Это, во-первых, ценностные ориентации на выживание человечества, на заботу о будущих поколениях. Во-вторых, это экологическая функция, направленная на сохранение природных ресурсов и экологических условий для существования человека. В целом современная образовательная система должна стремиться к изменению парадигмы образования от техногенно-экономической к гуманистической, экологической и культурологической.

\section{Примечания}

1. Философия науки в вопросах и ответах : учеб. пособие для аспирантов / Кохановский В. П. [и др.]. Ростов н/Д : Феникс, 2008. 346 с.

2. Томсон М. Философия науки / пер с англ. А. Гарькавого. М. : ФАИР-ПРЕСС, 2003. 304 с.

\section{References}

1. Filosofija nauki $\mathrm{v}$ voprosakh $\mathrm{i}$ otvetakh : ucheb. posobije dlja aspirantov [Philosophy of science in questions and answers : manual for the post-graduates] / Kokhansky V.P. [et al]. Rostov n/D, 2008. 346 p. [In Russ.].

2. Tomson M. Filosofija nauki [Philosophy of science] / transl. from English by A. Garkavy. M., 2003. 304 p. [In Russ.]. 
Jan Li

\section{ПРИМЕНЕНИЕ ЛЕКСИЧЕСКОГО ПОДХОДА «ИЕРОГЛИФ КАК ОСНОВНАЯ ЕДИНИЦА» ПРИ ОБУЧЕНИИ КИТАЙСКОМУ ЯЗЫКУ КАК ИНОСТРАННОМУ \\ THE APPLICATION OF THE LEXICAL APPROACH «HEIROGLYPH AS A BASUC UNIT» IN TEACHING CHINESE AS A FOREIGN LANGUAGE}

В течение многих лет преподавание китайского языка как иностранного всегда основывалось на подходе «слово как основная единица», хотя данный подход достиг в определенной степени признания специалистами, но в целом результат обучения по данному методу не очень оптимистичен, и существует проблема, что устные способности учащихся не соответствуют письменным. Автор считает, что метод обучения «иероглиф как основная единица» должен быть принят в лексическом подходе обучения, то есть «иероглиф» является основной единицей, и следует принцип «из иероглифа создавать слово, а из слова образовывать предложение». В этой статье рассматривается применение подхода «иероглиф как основная единица» в преподавании для начинающих изучать китайский язык, а также выдвигаются предложения по улучшению способностей понимания и чтения у учащихся, эффективности преподавания китайскому языку.

For many years, teaching Chinese as a foreign language has always been based on the "word as a basic unit" approach, although this approach has achieved a certain degree of recognition of the experts, but in general, the result of training, according to this method, is not very optimistic, and there is a problem that oral abilities of students do not correspond to the written ones. The author believes that the teaching method "hieroglyph as a basic unit" should be adopted in the lexical approach of teaching, that is, "hieroglyph" is the basic one and the principle that follows is "to create a word from a hieroglyph and form a sentence from a word". The article considers the use of the "hieroglyph as a basic unit" approach in teaching Chinese to beginners, and suggestions are made to improve learners' understanding and reading skills and the efficiency of teaching that language.

Ключевые слова: основная единица, иероглиф, подход «иероглиф как основная единица», подход «слово как основная единица», метод преподавания китайскому языку как иностранному

Keywords: basic unit, hieroglyph, "hieroglyph as a basic unit"approach, "word as a basic unit" approach, method of teaching Chinese as a foreign language. 
Язык - это важнейший аспект культуры, который отражает ценности и образ мышления разных народов и выражается звуками. Китайские иероглифы представляют собой идеограммы в уникальной конфигурации. Тем не менее, при преподавании китайского языка долгое время пренебрегали иероглификой, копируя западную языковую теорию. В практике преподавания была ситуация, когда «аудирование и говорение лидируют, а написание и чтение отстают». В последние годы это положение стало улучшаться, и были достигнуты некоторые результаты исследований, но они все еще недостаточны и требуют дальнейшего изучения. С этой целью мы намерены выяснить связь основной единицы с китайским языком, а также связь между основной единицей обучения китайских иероглифов, разграничить концепции «иероглиф как основная единица» и метод обучения «иероглиф как основная единица».

\section{1. Значение основной единицы}

Начиная с 20-го века, «основная языковая единица» была одной из важных тем в исследованиях китайского языка. Значение данной единицы многие ученые определяют следующим образом: единица языка первого уровня, теоретическое ядро изучения структуры языка и определение позиции других единиц в языковой системе. Со времен основания Нового Китая западные лингвистические теории оказывали влияние на преподавание китайского языка как иностранного в родной языковой среде [2]. В то же время слово было основной единицей обучения, последовательность обучения была составлена в соответствии с частотой употребления слов, и подчеркивалась коммуникативная функция слов. В 1980-х годах некоторые ученые выяснили взаимосвязь между китайским иероглифом и его звучанием и предложили метод обучения «иероглиф как основная единица», это привело к мысли о преподавании китайских иероглифов. Существует множество противоречивых взглядов на основную структурную единицу китайского языка, и на взаимосвязь между словом и иероглифом. До сих пор нет ясности в определении значения «основная единица» и её различных методов обучения [3]. Фактически, любое успешное обучение языку должно всесторонне исследовать различные элементы языковой структуры, и обучение языку должно включать одновременное освоение идеограмм и фонетиков. Если мы сможем правильно понять единицу языковой структуры, мы сможем глубоко проанализировать законы языковой системы и достичь лучших результатов в преподавании языка. Поэтому мы считаем, что «основная единица» в преподавании китайского языка как иностранного это:

- важная основа для преподавания китайского языка;

- базовая единица для преподавания китайского языка;

- органическая комбинация компонентов китайских иероглифов.

2. Теория «слово как основная единица» и её метод обучения

В процессе взаимодействия китайского языка и западных языков была обнаружена структурная единица, отличная от иероглифа - слово. 
Понятие слова впервые появилось в «Объяснении правил письменного языка господина Ма», опубликованном в 1898 году. Ма Цзяньчжун не использовал термин «слово» в своей книге, но использовал термин «иероглиф». Поэтому «иероглиф» в работе господина Ма имеет два значения: одно относится к китайскому иероглифу, второе относится к слову, то есть к языковой единице, которую можно использовать независимо. С тех пор понятие «слово» вошло в китайский язык и была создана теория китайской грамматики, которая использовала концепцию «слово как основная единица». В 1956 году была введена временная система преподавания китайской грамматики, которая разбила китайскую грамматику на три единицы - слово, фраза и предложение - и определила, что слово является основной единицей китайского языка. Под влиянием этого обучение китайскому языку как иностранному основывается на методе обучения «слово как основная единица».

\section{1. Грамматический центризм}

Слово - это единица, которая используется в качестве обучения китайскому языку, принимает структурную последовательность китайской грамматики в качестве базы, согласно грамматической структуре частоты слов упорядочивает последовательность обучения, и, следовательно, не заметен тот факт, что слова состоят из иероглифа и закона внутренней семантической структуры. Поэтому в прошлом столетии изучение грамматики китайского языка находилось под влиянием теории «слово как основная единица».

2.2. Грамматика важнее написания

Слово - это не только единица китайского языка первого уровня, но и форма письменности, то есть «文». Некоторые люди выступают за изучение китайского языка с помощью пиньинь (транскрипция китайских иероглифов латинскими буквами). Некоторые люди даже выступают за замену китайских иероглифов на пиньинь. Они даже предлагают компьютерное обучение китайскому языку, которое распознает и пишет только пиньинь, и напрямую исключающее написание китайских иероглифов. В то время преподавание китайского языка как иностранного дошло до концепции «грамматика важнее написания», что привело к мнению, что достаточно изучения грамматики без написания иероглифа [6, с. 106].

Фактически, китайский и индоевропейский языки - это две совершенно разные языковые системы. Соссюр считает, что в мире существует два типа систем письменности: идеографическая и фонографическая системы. Китайский язык представляет первый тип, а индоевропейские второй. В 1975 году известный лингвист Чжао Юаньжэнь подчеркнул, что «До недавнего времени в китайском языке не считалось слово. В концепции китайского народа иероглиф является центральной единицей. Роль иероглифа и «слово» в английском языке тождественны. «Некоторые ученые постепенно обнаружили различные недостатки метода обучения «слово как основная единица»: обучение лексики игнорирует характеристики китайского словаря, игнорирует закон конфигурации китай- 
ских иероглифов и семантические особенности морфем как смысловых единиц и способность словообразования. Статус метода обучения «слово как основная единица» начал колебаться» [5, с. 13].

3. Теория «иероглиф как основная единица» и её метод обучения

Недостатки теории «слово как основная единица» и её методы обучения привели к тому, что научные круги стали искать другой путь развития и изменять грамматически-ориентированный подход. В работе «Языковые беседы» Люй Шусян упомянул, что для индоевропейских языков базовая грамматическая единица очень очевидна - это слово. В китайском языке наоборот, считается, что иероглиф - это основная единица. Лингвистическая проблема заключается в изучении определения сложных иероглифов как слова или как словосочетания [1, с. 45].

Сюй Тунцян официально выдвинул теорию «иероглиф как основная единица» в работе «Теории языка» (1997). Он считает, что наименьшей единицей письменности в китайском языке является иероглиф, которое является троицей (форма, звучание и значение). В последние годы некоторые ученые опубликовали серию статей о теории «иероглиф как основная единица». Некоторые поддержали теорию «иероглиф как основная единица», обсудили её применение в преподавании китайского языка как иностранного, особенно на словарном обучении. Другие основывались на методе обучения «иероглиф как основная единица». В статье обсуждается ее применение в преподавании китайского языка как иностранного [4, с. 13].

В 1989 году французский китаист Жоэль Беллассен выдвинул теорию «иероглиф как основная единица» в китайском учебнике на французском языке, написанном вместе с Чжаном Пэнпэном. На его взгляд мнения китайских ученых также неоднозначны и противоречивы. Профессор Лу Цзяньмин высоко оценил метод обучения «иероглиф как основная единица», предложенный Жоэль Беллассеном: «Способ обучения «иероглиф как основная единица» господина Жоэль Беллассена заключается в том, что обучение китайским иероглифам - это не только аккуратное написание, но и объяснение каждой черты в иероглифе, порядка написания графем, ключей, комбинации компонентов и структур, источников слов, эволюции каждого иероглифа, культуры иероглифа, значения и звучания иероглифа, комбинация иероглифа в слове» [8, с. 102]. Ван Жоцзян поддержал данный учебник и еще раз подчеркнул принцип расширения слов на основе иероглифов. Можно видеть, что метод обучения «иероглиф как основная единица» подчеркивает, что обучение китайскому языку основано на «иероглифах» и соблюдает экономический принцип «образование слов из иероглифов» в преподавании китайского языка, то есть предшествует выбор иероглифа, а затем следует образование слова. Подход обучения китайскому языку «иероглиф как основная единица» придерживается характеристик китайского языка, ориентированности на учащихся. Данный метод осуществим и практичен при обучении начинающего уровня [7, с. 65]. 
4. Применение метода обучения «иероглиф как основная единица» в иероглифическом обучении китайскому языку как иностранному

Наименьшая единица в китайском языке - это иероглиф, а китайский иероглиф - это главным образом односложная идеограмма, имеющая квадратную форму. В китайском языке много одинаково звучащих иероглифов и иероглифов с одинаковым написанием. Чтобы по-настоящему выучить китайский язык, иностранные студенты должны глубоко понимать китайские иероглифы. Преподавание китайской иероглифики очень важно при обучении китайскому языку как иностранному в целом.

4.1. Последовательность преподавания иероглифики.

Во-первых, начать нужно с черт иероглифа. Черты - это самая маленькая непрерывная единица, составляющая форму китайского иероглифа. Существует 28 черт китайских иероглифов, и выделяют пять основных: горизонтальная, вертикальная, откидная влево, точка, ломанная. В процессе обучения следует показывать черты китайских иероглифов и их порядок черт для запоминания обучающимися. В процессе обучения студенты должны одновременно познакомиться с простыми и высокочастотными иероглифами для прочного закрепления базовых черт. Такая графема как “口” поможет обучить вертикальным, горизонтальным и ломанным чертам. Дальше студент составляет иероглиф “吃、喝”и т.д., чтобы помочь студентам установить концепцию «словесный род».

Кроме того, мы должны подчеркнуть порядок написания: учащиеся, не имеющие базовых знаний по культуре китайских иероглифов, часто пишут их, слепо копируя, и черты получаются неправильные. Иногда даже «горизонтальная» идет справа налево, поэтому на начальной стадии обучения важно понять порядок написания иероглифа.

Во-вторых, взять в качестве ключевого звена комбинацию графем.

Большинство древних китайских иероглифов представляют собой пиктограммы, идеограммы и указательные иероглифы, которые являются простыми иероглифами. На более позднем этапе он превратился в сложный иероглиф и пиктофонетическую категорию, но большинство ключей были получены из простых иероглифов.

Ключи являются основными единицами, которые составляют сложный иероглиф. Есть много китайских иероглифов, но количество графем ограниченно. Согласно статистике, 11834 китайских иероглифа имеют 648 одинарных графем. Анализ графем для изучения и применения китайских иероглифов может получить неожиданный результат. В первую очередь должно быть объяснено основное значение каждой графемы, представлены иероглифы, образованные из этих графем, чтобы позволить студентам понять значение этих иероглифов. Кроме того, необходимо правильно представить гадательные надписи на костях и черепашьих панцирях, чтобы студенты могли понять эволюцию китайских иероглифов и повысить интерес к учебе. 
В-третьих, ввести четыре комбинации графем, например левую и правую комбинации, верхнюю и нижнюю комбинации, окружающую комбинацию, комбинацию обрамления, например, такие как: левая и правая комбинация (汉、脚), комбинация верхнего и нижнего (导、带), окружающая комбинация (床、旬、题、闻、凶、臣、国), комбинация обрамления (爽、哥). Это позволит студентам понять комбинации этих компонентов, овладеть структурой написания китайских иероглифов и писать китайские иероглифы правильно и красиво.

4.2. Обучение значению иероглифов.

После того, как студенты овладеют формой и значением простых иероглифов, станет легче понимать значение сложных иероглифов. Иероглиф пиктофонетической категории является важным символом развития китайских иероглифов и состоит из графем значения и звучания. При обучении иероглифам пиктофонетической категории студентам нужно объяснить, что является графемой значения и графемой звучания. Хотя значение графем иногда далеко от значения иероглифа, оно может объяснить значение по форме иероглифа, что создает образ мышления по-китайски. Также необходимо ознакомить студентов с древней формой и значением и объяснить роль графем-звучания иероглифа в произношении. Несмотря на то, что существуют определенные ограничения в графемах значения и звучания, это позволяет студентам понимать некоторые правила, которые помогают различать значение и произношение иероглифа.

5. Применение подхода обучения «иероглиф как основная единица» в лексическом преподавании китайского языка как иностранного

Количество наиболее распространенных китайских иероглифов около 2500. Неограниченное количество слов является наиболее активным фактором в языке. Иероглиф в качестве основной единицы и в качестве отправной точки для обучения является быстрым способом развития у студентов способности познания языка. Благодаря иероглифам и сочетанию иероглифов словарный запас студентов растет всё больше, развивается способность учащихся улучшать понимание прочитанного. Даже если они встречают неизвестные китайские иероглифы, они могут догадываться о значении иероглифа, основываясь на форме и контексте. Овладев начальными знаниями о китайском языке, они будут разделять структурные единицы составляющих иероглиф, объяснять их значение, а затем образовывать слова из иероглифов, показывать словообразовательную способность иероглифов, расширять словарный запас.

Конкретные практики обучения заключаются в следующем:

5.1. Расширение словарного запаса, используя части речи и члены предложения.

Слово в китайском языке может являться несколькими частями речи, но отличатся по значению с неизменным произношением. Как разные части речи, одно и то же слово может иметь разные произношения, указывая на разные значения. В процессе обучения нужно сознательно 
преподавать слова, выступающие в качестве разных частей речи и приводить соответствующие примеры в сочетании с контекстом.

5.2. Обогащение словарного запаса при помощи синонимов

В китайском языке существует много синонимов и близких по смыслу слов, которые обогащают словарный запас и повышают точность выражения языка. Разница между синонимами и близкими по значению словами только в стилистической окраске.

5.3. Усвоение способов словообразования в китайском языке

При обучении лексике преподаватель должен обращать внимание на расширение словарного запаса учащихся на любом этапе (начальном, среднем и продвинутом). В соответствии с семантической связью слов, это позволяет учащимся понимать значение и его использование в разных контекстах. Также нужно обратить внимание на усвоение лексики учащихся, тем самым развивать способность образовывать слова, разделять близкие по значению слова, частоте употребления, определенному и общему, словосочетанию, эмоциональной окраске, стилистической окраске и по частям речи, анализировать тонкие семантические различия между ними, различать и повышать точность использования слов.

\section{4. Преподавание китайской культуры}

В практике преподавания, для того, чтобы студенты активно и с интересом учились, нужно полное погружение в другую культурную действительность. Знакомство с культурой должно идти на протяжении всего обучения. В практике преподавания необходимо применять пространственно-временной и ассоциативный методы, которые способствуют развитию представления обучающихся о связи языка и культуры.

Соответственно, преподаватель в обучении лексике должен проследить, чтобы студенты овладели не только значением слов, но и знаниями о культуре Китая.

\section{6. Выводы}

Таким образом, на начальном этапе изучения китайского языка при обучении китайским иероглифам и словарному запасу эффективен метод обучения «иероглиф как основная единица», это позволяет в полной мере использовать ассоциативные связи, а также познакомиться основами китайской письменной культуры. Включение иероглифов в преподавание лексики позволяет студентам образовывать новые слова из иероглифов, а затем формировать семантическое поле. Это не только помогает учащимся расширять словарный запас, но также помогает распознавать синонимы, обогащать свою речь, углублять понимание и применение китайского языка, и, целом, понять культуру Китая.

\section{Примечания}

1. Люй Шусян. Юйвэнь чантань. [Языковые беседы. Пекин : Саньлянь, 1980. 45 с.] (на китайском языке: 吕叔湘. 语文常谈[M]. 北京.三 联书店,1980). 
2. Пань Вэньго. Ханьюй яньцзю: шицзи чжи цзяодэ сыкао. [Исследования по китайскому языку: рассуждения на рубеже веков // Лингвистические исследования. 2002. №1.] (на китайском языке: 潘文国. 汉语研究 :世纪之交的思考 [J].语言研究, 2000,(1).

3. Пань Вэньго. Цзытивэй юй ханьюй яньцзю. [Исследования подхода «иероглиф как основная единица» в китайском языке // Вестник Восточно-китайского педагогического университета, 2002.] (на китайском языке: 潘文国.字本位与汉语研究 $[\mathrm{M}]$.上海: 华东师范大学出版社, 2002).

4. Сюй Тунцян. Юйянь лунь. [Лингвистическая теория] // Вестник Северо-восточного Пекинского педагогического университета, 1997.] (на китайском языке: 徐通铭. 语言论[M].东北师大出版社, 1997).

5. Чжао Юаньжэнь. Чжао Юаньжэнь юйяньсюэ лунь вэньсюань // Собрание статей по языкознанию Чжао Юаньжэна. Пекин, Коммерческое изд-во, 2002.] (на китайском языке: 赵元任. 赵元任语言学论文选 [C]. 北京, 商务印书馆, 2002).

6. Ши Чжэнюй. Цун ханьцзы цзяосюэ каньдуй вай ханьюй цзяосюэ чжундэ бэньвэй вэньти. [Вопросы по основной единице в практике преподавания иероглифики в китайском языке // Национальное образование. 2010. № 6. С. 105.] (на китайском языке: 施正宇. 从汉字教学 看对外汉语教学中的本位问题 $[\mathrm{J}]$. 民族教育研究, 2010, (06).

7. Ван Жоцзян. Ю фаго «цзытивэй» ханьюй цзяоцай иньфадэ сыкао. [Размышления напечатанные в французском учебном пособии по китайскому языку подхода «иероглиф как основная единица» // Преподавание китайского языка в мире. 2003. №3. С. 91-96.] (на китайском языке: 王若江. 由法国“字本位”汉语教材引发的思考 $[\mathrm{J}]$.世 界汉语教学, 2000, (3).

8. Лу Цзяньмин. Во гуаньюй «цзытивэй» дэ цзибэнь гуаньдянь. [Моя точка зрения на подход «иероглиф как основная единица» // Исследование в практике преподавания языка. 2011. № 3. С. 225-228.] (на китайсокм языке: 陆俭明. 我关于 “字本位” 的基本观点 [J. 语言教学与研 究, 2011, (3).

\section{References}

1. Lui Shusyan. Language conversations. Beijing: Sanlian Publishing House, 1980. 45 p. [In Engl.].

2. Pan Wengo. Studies on the Chinese language: reasoning at the turn of the century // Linguistic research. 2002. №1 [In Engl.].

3. Pan Wengo. Research approach "Hieroglyph as a basic unit" in Chinese // Bulletin of East China Pedagogical University, 2002 [In Engl.].

4. Xu Tongqiang. Linguistic Theory // Bulletin of Northeast Beijing Pedagogical University, 1997 [In Engl.]. 
5. Zhao Yuanren // Collection of articles on linguistics by Zhao Yuanren. Beijing, Commercial Publishing House, 2002 [In Engl.].

6. Shi Zhenyui. Questions on the basic unit in the practice of teaching hieroglyphics in Chinese // National Education. 2010. No. 6. p. 105 [In Engl.].

7. Wang Jojiang. Reflections printed in the French textbook on the Chinese language approach "hieroglyph as the basic unit" // Teaching Chinese in the World. 2003. №3. Pp. 91-96 [In Engl.].

8. Lu Jianming. My point of view on the approach "hieroglyph as a basic unit" // Research in the practice of language teaching. 2011. No. 3. P. 225-228 [In Engl.]. 
DOI 10.31443/2541-8874-2019-2-10-157-160

УДК 378.147.88:791.6

Николаева Н.В.

Nikolaeva N.V.

О НЕКОТОРЫХ ПРОБЛЕМАХ ОРГАНИЗАЦИИ ПРАКТИКИ В ПРОЦЕССЕ ОБУЧЕНИЯ СТУДЕНТОВ ПО НАПРАВЛЕНИЮ ПОДГОТОВКИ «РЕЖИССУРА ТЕАТРАЛИЗОВАННЫХ ПРЕДСТАВЛЕНИЙ И ПРАЗДНИКОВ»

\section{SOME PROBLEMS OF ORGANIZING PRACTICAL TRAINING IN THE PROCESS OF EDUCATING THE STUDENTS MAJORING IN DIRECTING OF THEATRICAL PERFORMANCES AND HOLIDAYS}

Статья посвящена некоторым проблемам организации практики в процессе обучения студентов по направлению подготовки «Режиссура театрализованных представлений и праздников» и способы их решения.

The article is devoted to some problems of organizing practical training in the process of educating the students majoring in directing of theatrical performances and holidays and the ways of their solution.

Ключевые слова: учебная практика, производственная практика, преддипломная практика, культурно-досуговое учреждение, база практики.

Keywords: educational practical training, practical training at work, pre-graduation practical training, leisure cultural institution, practical training base.

Проблемы подготовки режиссеров-сценаристов - специалистов праздничной индустрии - не теряют своей актуальности. Одной из них, несомненно, является усиление практической направленности обучения, поскольку в современных условиях меняются парадигмы театрализованных форм праздничной культуры; освоение современных инноваций в этой сфере является залогом успешной самостоятельной профессиональной деятельности выпускников.

На кафедре режиссуры театрализованных представлений и праздников ВСГИК уделяется большое внимание как организации, так и содержанию практики. Практика организуется в соответствии с Федеральным государственным образовательным стандартом высшего образования, Положением о порядке проведения практики студентов ФГБОУ ВО ВСГИК, утвержденным приказом ректора от 2018 г., учебным планом направления подготовки 51.03.05 «Режиссура театрализованных представлений и праздников». Учебный план, разработанный на основе ФГОС, предусматривает прохождение студентами нескольких видов практики в процессе их обучения: учебной, производственной и преддипломной, общим объемом 10 недель. 
Учебная практика (по получению первичных профессиональных умений и навыков, в том числе первичных умений и навыков научно-исследовательской деятельности), производственная практика (по получению профессиональных умений и опыта профессиональной деятельности) и производственная (преддипломная) практика организуются с целью закрепления и совершенствования профессиональных навыков, полученных во время теоретического обучения и освоения практических умений и навыков сценарно-режиссерской продюсерской и других видов деятельности [1]. Эти знания, умения и навыки закрепляются практической деятельностью в условиях реального осуществления театрализованных культурно-досуговых проектов.

Данные виды практики направлены на формирование общепрофессиональных и профессиональных компетенций, определяемых ФГОС в разделе стандарта «Требования к результатам освоения программ бакалавриата по направлению подготовки» [2].

Поэтому практика студентов, организуемая кафедрой РЭТП ВСГИК, в концентрированном виде содержит тот набор практических профессиональных знаний, умений и навыков, который позволит студенту в будущем состояться как профессионалу в сфере культуры, в целом и режиссуре ТПиП, в частности. В связи с этим актуальным становится и вопрос о повышении продуктивности практики.

На кафедре в последние годы активно проводится работа по организации прохождения практики не только в учреждениях культуры Республики Бурятия, но и за ее пределами: в Иркутской, Тюменской, Новосибирской, Оренбургской областях, Приморском, Забайкальском и Красноярском краях, республиках Саха (Якутия) и Тыва. В 2018 г. кафедра вышла на международный уровень, организовав практику студентов в Монголии, Китайской Народной Республике, республиках Беларусь и Казахстан.

Одним из примеров успешной организации практики является Краевое государственное бюджетное учреждение культуры «Центр культурных инициатив» г. Красноярска. В течение пяти лет данное учреждение ежегодно является основной базой практики студентов кафедры РЭТП.

Руководство центра всегда готово к взаимодействию с руководителем практики от образовательного учреждения, обеспечивает всеобъемлющую методическую помощь практикантам и помогает им легко пройти период адаптации. Практикантов активно включают во все виды деятельности учреждения. И во многом, как отмечают студенты в своих отчетах, эта практика предоставляет возможность еще раз убедиться в правильности выбора профессии, освоить различные виды деятельности, а также способствует трудоустройству в данной организации.

По нашему мнению, база практики должна быть стартом для личностного и профессионального роста студентов, для успешной профессиональной деятельности в области режиссуры театрализованных представлений и праздников. 
Вузом заключены долгосрочные договоры со многими потенциальными работодателями на прохождение всех видов практик. Осуществляются выезды на базы практик, где студенты активно участвуют в культурно-досуговой деятельности предприятий и учреждений, анализируют организационно-методические материалы, проводят профориентационную работу на местах прохождения практики, проявляют инициативу по внедрению инноваций. В результате нередко студентов, обучавшихся по направлению подготовки «Режиссура ТПиП», приглашают впоследствии в качестве специалистов в учреждение, где они проходили практику. Все это говорит о конкурентоспособности наших выпускников на рынке труда, а также о позитивном настрое на совместную работу с кафедрой со стороны руководства и специалистов баз практик.

Однако, несмотря на успешный в целом опыт взаимодействия с учреждениями культуры, образования, спорта и молодежной политики, организации и проведению практик студентов данного направления подготовки, необходимо указать и на имеющиеся проблемы.

Во-первых, это касается адаптации студентов на базе прохождения практики. За две недели студенту трудно освоиться в новых условиях, глубоко ознакомиться со структурой и конкретными видами деятельности культурно-досугового учреждения, его специалистами, организационноправовыми документами, регламентирующими деятельность учреждения. Попадая в реальные условия, практикант не всегда справляется с поставленными задачами различного организационно-управленческого, творческо-постановочного, коммуникативного и иного характера, тем самым попадая в определенный «зажим», что приводит к недостаточно качественным результатам практики.

Поэтому стоит рассмотреть вариант с внедрением этапа прохождения учебной практики уже на первом курсе без отрыва от учебного процесса с тем, чтобы студенту было легче адаптироваться и привыкнуть к новым условиям, а также ознакомиться с различными профессиональными ситуациями, которые возникают в процессе прохождения практики и которые могут прокомментировать и дать соответствующие рекомендации преподаватели кафедры.

Во-вторых, проблемой является недостаточная продолжительность периода прохождения всех видов практики. По учебным планам предусмотрены две недели для организации учебной практики, четыре недели для производственной практики и четыре - для производственной (преддипломной) практики, что явно недостаточно. Как правило, при подготовке мероприятия театрализованных форм праздничной культуры обязательны организационно-подготовительный и творческо-постановочный этапы, которые подчас занимают немалое время, и уложить эту работу в периоды, отведенные программой прохождения практики не всегда возможно.

Увеличение длительности всех видов практики, несомненно, улучшит качество ее прохождения и поднимет уровень освоения компетенций, предусмотренных программой практики. 
В-третьих, мы сталкиваемся с излишне формальным отношением руководителей баз практики. Нередки случаи, когда перед студентом встает вопрос об организации непосредственного взаимодействия со специалистами учреждений. Практиканту не всегда доверяют решение профессиональных задач. Поэтому эффективность прохождения практики в этом случае является довольно низкой. Зачастую прохождение практики сводится к определенной формальности. Здесь возможен такой вариант, как отсутствие необходимой мотивации должностных лиц, ответственных за практику в профильных организациях.

В-четвертых, несоответствие вузовских программных требований к прохождению практики, возможностям и сиюминутным задачам баз практики. Здесь необходимо более глубокое взаимодействие кафедры с базами практики и учет их возможностей при формировании планов-графиков и программ практики.

Таким образом, при решении указанных проблем можно добиваться более эффективных результатов учебной, производственной и преддипломной практик.

\section{Примечания}

1. Федеральный государственный образовательный стандарт высшего образования по направлению 51.03.05. Режиссура театрализованных представлений и праздников : от 25.09.2015. URL: http//fgosvo.ru/510305 (дата обращения: 12. 04.2019).

2. Положение о порядке проведения практики обучающихся, осваивающих основные профессиональные образовательные программы высшего образования ФГБОУ ВО ВСГИК : утв. 02.02.2018. URL: http://www.vsgaki.ru/download-5937. (дата обращения: 12.04.2019).

\section{References}

1. Federalnyj gosudarsvennyj obrazovatelnyj standart vysschego obrazovanija po napravleniju 51.03.05 Rezhissura teatralizovannykh predstavlenij i prazdnikov [Federal state educational standard of higher education for the specialty 51.03.05 Directing of theatrical performances and holidays]. URL: http//fgosvo.ru/510305 (12. 04.2019) [In Russ.].

2. Polozhenije o poryadke provedenija praktiki obuchajuschikhsja, osvaivajuschikh osnovnye professionalnye obrazovatelnye programmy vysschego obrazovanija FGBOU VO VSGIK [Regulations on the procedures for conducting practical training of the learners mastering major professional educational programs of higher education at FSBEI HE ESSIC: approved 02.02.2018. URL: http://www.vsgaki.ru/download-5937 (12.04.2019) [In Russ.]. 
DOI 10.31443/2541-8874-2019-2-10-161-168

УДК 159.947.5:378

Покацкая Е. И.

Pokatskaya Ye.I.

\section{ДИНАМИКА МОТИВАЦИИ СТУДЕНТОВ ТВОРЧЕСКОЙ СПЕЦИАЛЬНОСТИ В ПРОЦЕССЕ ОБУЧЕНИЯ В ВУЗЕ

\author{
DYNAMICS OF MOTIVATION OF THE STUDENTS OF \\ CREATIVE SPECIALTY IN THE PROCESS OF STUDYING AT A \\ HIGHER EDUCATIONAL INSTITUTION
}

В статье описаны результаты психологического исследования особенностей мотивации учебно-профессиональной деятельности студентов 1-4 курсов направления подготовки «Режиссура театрализованных представлений и праздников». Определены мотивы актуальные, перспективные, а также мотивы, имеющие тенденцию к угасанию. Проведена интерпретация взаимосвязи преобладающих мотивов в соответствии с задачами обучения на каждом курсе.

The article describes the results of the psychological research of the motivation particulars of the educational and professional activities of the students of the $1^{\text {st }}-4^{\text {th }}$ courses majoring in «Directing of theatrical performances and holidays». Certain motives are defined as actual and promising as well as those motives that tend to be fading. The interpretation of the relationship of the prevailing motives in accordance with the objectives of training at each course has been made.

Ключевые слова: учебно-профессиональная деятельность, мотивация, мотив, актуальные мотивы, перспективные мотивы.

Keywords: educational and professional activities, motivation, motive, actual motives, promising motives.

Проблема профессиональной подготовки и последующей адаптации личности молодого специалиста в современных условиях является актуальной темой для исследований в области гуманитарных наук. Основной проблемой профессионального образования, как отмечает А.А. Вербицкий [1], является переход от учения к труду, заключающийся в зарождении и формировании профессиональной деятельности в рамках деятельности учебной. Оптимизация данного процесса невозможна без опоры на главную детерминанту деятельности субъекта - мотивацию. Мотивация к деятельности предполагает готовность реализовать целесообразное поведение и принимать на себя ответственность за соблюдение соответствующих нормативных требований и даже санкций за их несоблюдение в связи с осознанием необходимости деятельности и получения желаемого результата [4]. Следовательно, необходимым условием успешности учебно-профессионального процесса, а также будущей профессио- 
нальной деятельности является изучение мотивов профессионального выбора и формирование самой профессиональной мотивации студента.

Данная статья посвящена изучению мотивации учебно-профессиональной деятельности студентов творческой специальности, а также ее изменению в процессе обучения в вузе.

Творческая деятельность заключается в создании нового, ранее не существовавшего (оригинального) и требует от субъекта соответствующих личностных установок и качеств. С одной стороны, это способности к творчеству, как, например творческое мышление, особенности его структуры и уровневой организации $[5,6]$, с другой - сама потребность в творческом акте. Е.П. Ильин [2], описывая мотивацию творческой деятельности, выдвигает два основных положения: во-первых, познавательный интерес, во-вторых, стремление человека к значимости собственной личности, стремление сделать что-то качественно лучше, чем другие и не так, как все, в результате чего человек ищет возможность приложения своих сил и способностей. В связи с этим человек, занимающийся творческой деятельностью, находится в состоянии постоянной и систематической работы, направленной на совершенствование своего профессионального мастерства.

Для эмпирического изучения особенностей мотивации обучения студентов творческой специальности, мы определили выборку из числа студентов очного отделения 1-4 курсов направления подготовки 51.03.05 «Режиссура театрализованных праздников и представлений», численность выборки составила 40 человек.

В качестве психодиагностического инструментария мы использовали психографический тест, разработанный под руководством В.Г. Леонтьева [3] на кафедре психологии Новосибирского государственного педагогического университета. Студентам предлагался список мотивов, включающий в себя перечень внешних, внутренних, познавательных, социальных и профессиональных мотивов. Тест определяет, на какой стадии развития находятся определенные мотивы (зарождение, актуальное состояние, потенциал развития, тенденция к регрессии), а также то, какие мотивы выполняют главные побудительные функции. Для проведения интерпретации мы учитывали процент совпадений по выбору мотива в каждой группе курса, на основании чего мы имеем возможность проанализировать преобладающие мотивы в каждом поле: актуальная зона, перспективная зона, зона низкой мотивации.

Зона актуальных мотивов, по определению авторов, есть «пространство высокого уровня мотивации». В данной зоне находятся сильные, динамично развивающиеся мотивы, являющиеся главным побудительным фактором деятельности. Перспективная зона - «пространство потенциала мотивации» [3, с. 139]. В этом поле находятся мотивы, которые субъект пока не реализует в активном плане действий, они представлены в виде желаний. В зоне низкой мотивации находятся мотивы, которые либо утратили свое значение (регрессия), либо еще его не приобрели. 
Приведем описание полученных результатов.

В структуре мотивов студентов первого курса (см. рис. 1) преобладают мотивы, связанные со стремлением к самосовершенствованию и реализации в творческой деятельности («свободный дух профессии»). Мы считаем, что данные стремления выходят на первый план вследствие основной характеристики кризиса перехода к юности - становление человека как субъекта собственного развития. В соответствии с задачами возрастного периода, юноша переступает порог самостоятельной взрослой жизни, что связано с построением перспективных планов и присвоением учебной деятельности нового смысла [7]. В соответствии с этим, мы находим закономерным нахождение в актуальной зоне мотива «реализация жизненной цели», а также мотива, связанного со статусной характеристикой («престиж профессии»).

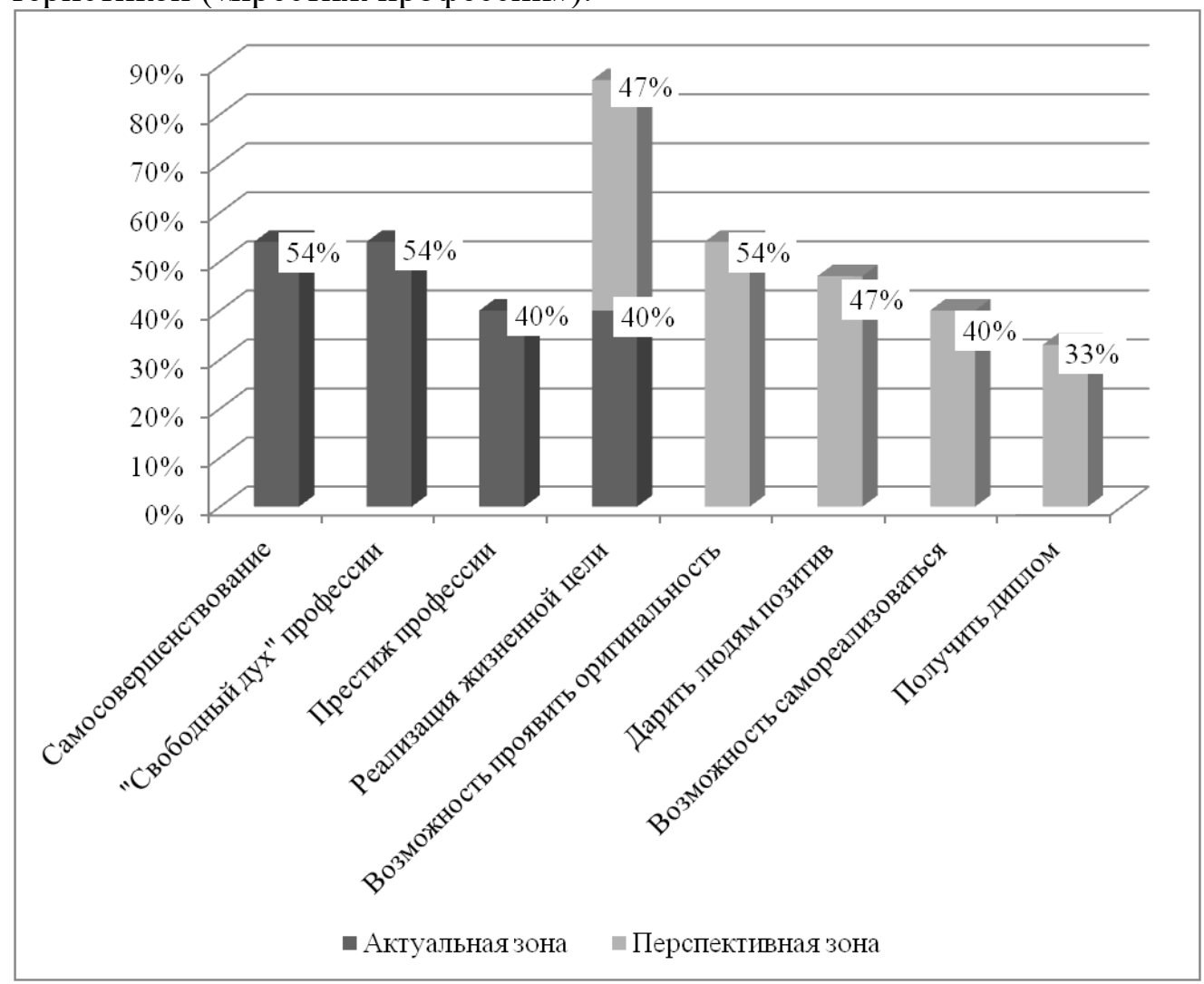

Рис. 1. Преобладающие мотивы студентов 1 курса, \%

В зоне перспективы преобладают мотивы, которые связаны с задачами самоактуализации, и мы предполагаем, что это отражает ожидания студентов от обучения на выбранном направлении подготовки, а также может быть следствием особых потребностей творчески одаренных личностей в саморазвитии и достижении высоких результатов.

В зоне низкой мотивации такие мотивы, как «общение в коллективе» $(54 \%)$ «легкость в учебе» $(47 \%)$, «отсутствие возможности поступить 
туда, куда хотелось» (47\%). Это может свидетельствовать о развитии внутренней мотивации и/или ее доминировании над мотивацией внешней.

По результатам выбора мотивов на втором курсе (рис. 2), мы наблюдаем сохранение в актуальной зоне мотивов «реализация жизненной цели», «дарить людям позитив». Отмечаем появление мотива «признание и успех» и определенным образом связанного с ним материального мотива «хороший заработок». В зоне перспективы мотивы, связанные со стремлением приступить к профессиональной деятельности («закончить вуз», «стремление работать по специальности», «дарить людям позитив»). Мы связываем этот факт с появлением в учебном процессе большого количества дисциплин, которые непосредственно раскрывают специфику режиссуры театрализованных праздников и представлений.

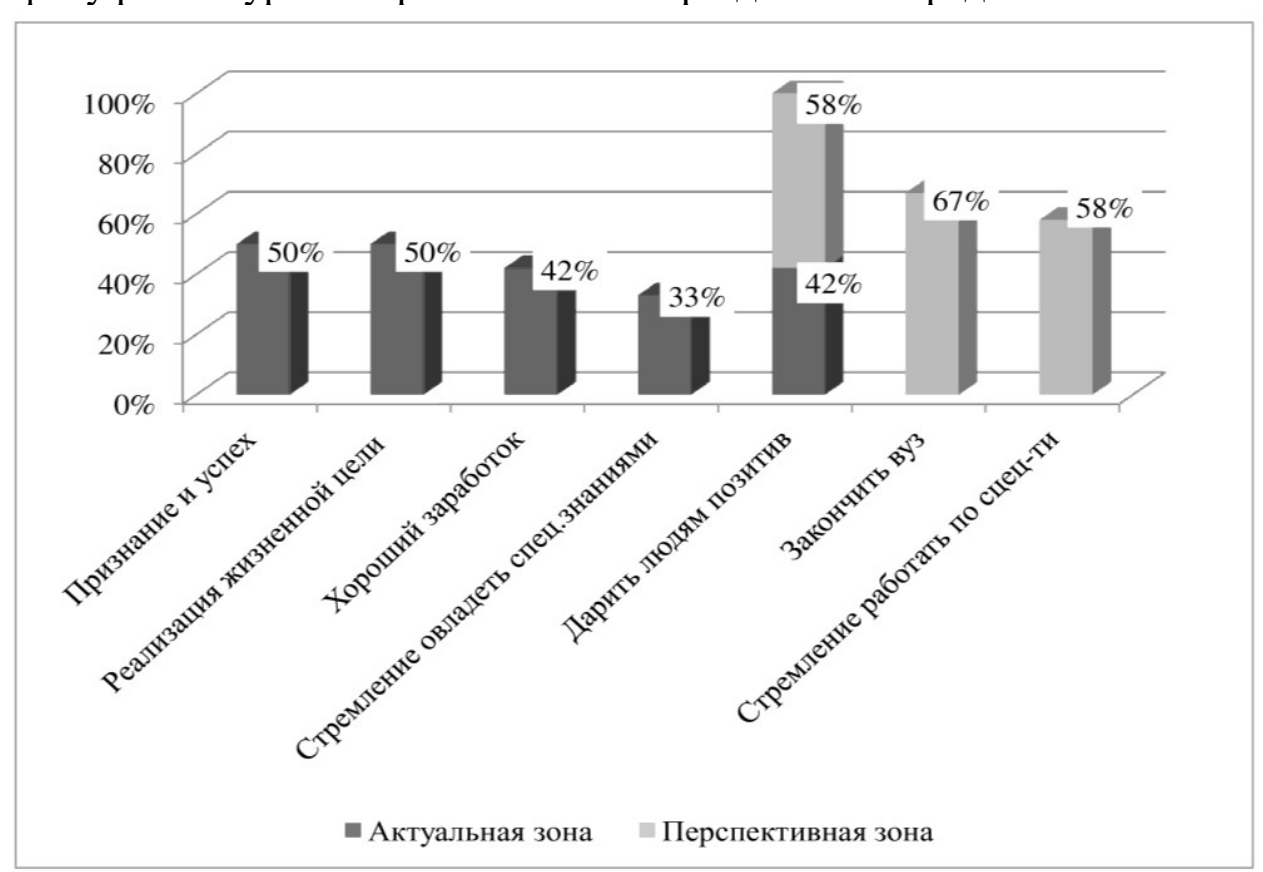

Рис. 2. Преобладающие мотивы студентов 2 курса, \%

В зону низкой мотивации помещены мотивы «гибкий график работы» (42\%), «отсутствие возможности поступить туда, куда хотел» (42\%), «возможность самореализоваться» $(42 \%)$ и и «наличие склонностей» (42\%). Мы обратили внимание на нахождение в данной зоне двух последних мотивов и предполагаем, что, учитывая актуализацию мотива «овладение специальными знаниями», это может указывать на смещение акцентов с самовыражения на приобретение опыта во взаимодействии с мастерами (своеобразная «вспышка конформизма»). Анализ расписания учебных занятий показал, что самое большое количество аудиторных занятий приходится на второй год обучения, что позволяет нам определить 
интенсификацию учебного процесса как стимулирующий фактор мотива «овладение специальными знаниями».

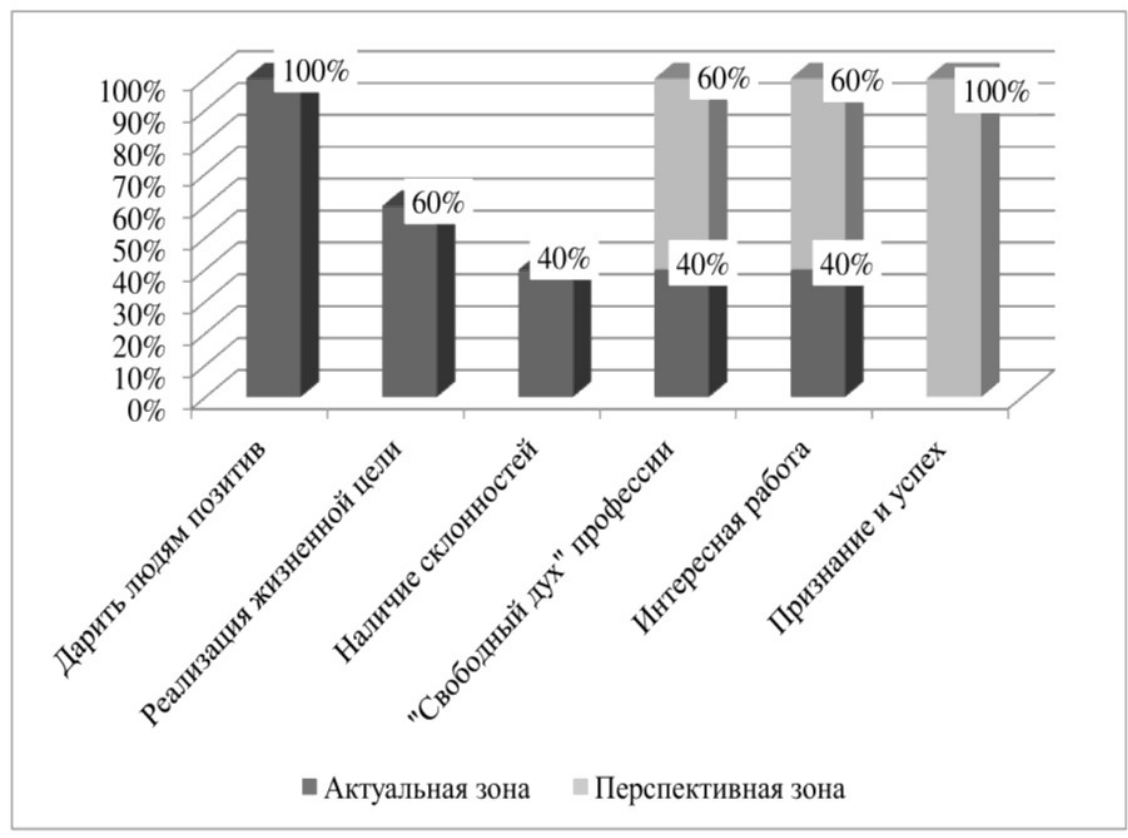

Рис. 3. Преобладающие мотивы студентов 3 курса, \%

В структуре мотивов студентов третьего курса (см. рис. 3) на первом месте характерные для всей выборки мотивы «дарить людям позитив» и «реализация жизненной цели». Студенты уже имеют опыт практического приложения полученных знаний, проявляется вера в собственную компетентность («наличие склонности»), отмечается положительный настрой на будущую деятельность («интересная работа», «свободный дух» профессии). В перспективе ярко выражено стремление достичь высоких результатов в деятельности («признание и успех»), а также мотивы, связанные с привлекательностью содержания будущей профессиональной деятельности.

В низкой зоне мотивации «легкость в учебе» $(60 \%)$, «общение в коллективе» (60\%), подтверждающие доминирование внутренней мотивации.

В структуре мотивов студентов выпускной группы в актуальную зону перешли мотивы, связанные с завершением обучения и положительным образом будущей работы (см. рис. 4). Мотив «интересная работа» характеризуется как особо побудительный (совпадающий с так называемой «линией жизни» в тесте). Зона перспективы представлена зарождением мотива «овладение основами профессионального мастерства». 


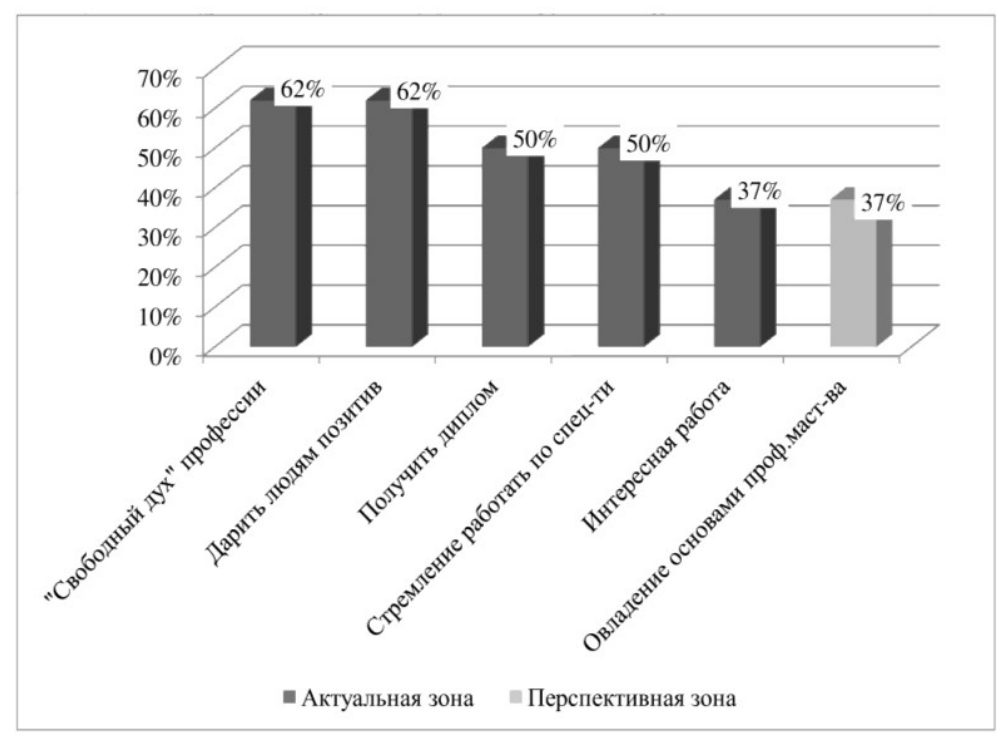

Рис. 4. Преобладающие мотивы студентов 4 курса, \%

Студенты-выпускники подводят итоги, оценивают результаты своей учебно-профессиональной деятельности, происходит переориентация с мотивов учебно-профессиональных на мотивы собственно профессиональные.

Также мы проследили, в каком соотношении находятся выраженность актуальной и перспективной зон мотивации на каждом курсе (см. рис.5.).

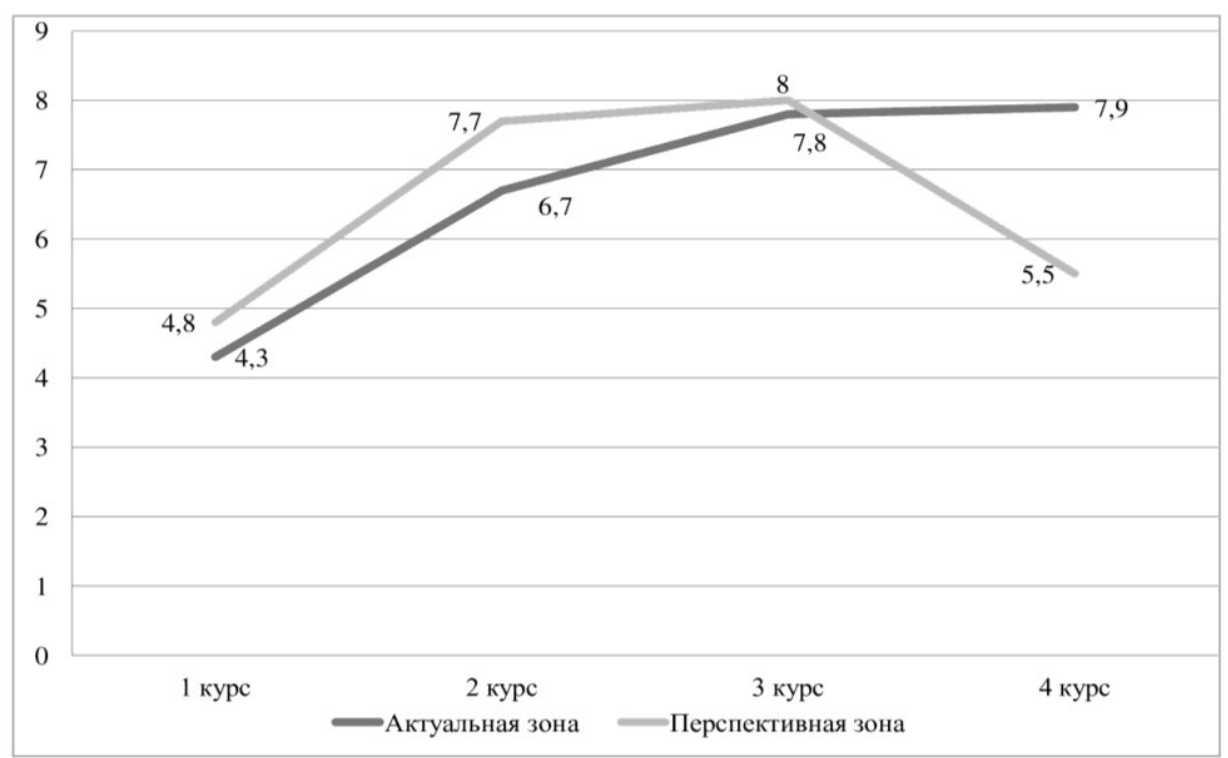

Рис. 5. Выраженность зон мотивации (средний расчет на 1 чел.)

На графике наглядно представлено, что, если с 1 по 3 курсы больше представлена сфера будущего, как пространство потенциала мотивации (мотивация в виде желаний), то для студентов-выпускников 
это будущее практически наступило, что закономерно отразилось на большей выраженности актуальной зоны.

Результаты проведенного исследования позволяют увидеть, что потребности и мотивы студентов творческих направлений подготовки меняются в зависимости от этапа обучения в вузе. Полученные выводы могут позволить выстроить содержание процесса обучения таким образом, чтобы стимулировать и поддерживать внутреннюю мотивацию студента и его самостоятельную работу по профессиональному и личностному росту.

\section{Примечания}

1. Бакшаева Н. А., Вербицкий А. А. Психология мотивации студентов : учеб. пособие. М. : Логос, 2006. 184 с.

2. Ильин Е. П. Психология творчества, креативности, одаренности. СПб. : Питер. 2009. 443 с.

3. Леонтьев В. Г. Мотивация и психологические механизмы ее формирования. Новосибирск : Новосиб. полиграфкомбинат, 2002. 264 с.

4. Петерсон Л. Г., Агапов Ю. В. Мотивация и самоопределение в учебной деятельности. М. : Ювента, 2013. 64 с.

5. Чернецкая Н. И. Творческое мышление и творчество: к проблеме соотношения понятий // Вестник ТвГУ. Серия «Педагогика и психология». 2013. Вып.1. С. 6-10. URL: https://elibrary.ru/item.asp?id=21272765 (дата обращения: 20.03.2019).

6. Чернецкая Н. И. Творческое мышление как единство процессуальных и личностных психических составляющих // Сибирский педагогический журнал. 2010. №11. С. 203-211. URL: https://elibrary.ru/item.asp?id=18041222 (дата обращения: 20.03.2019).

7. Шаповаленко И. В. Возрастная психология (психология развития и возрастная психология). М. : Гардарики, 2004. 349 с.

\section{References}

1. Bakshaeva N. A., Verbitskiy A. A. Psikhologija motivacii studentov [Psychology of students' motivation] : manual. M., 2006. 184 p. [In Russ.].

2. Ilyin E. P. Psikhologija tvorchestva, kreativnosti, odarennosti [Psychology of creativity, creativity, giftedness]. S.-P., 2009. 443 p. [In Russ.].

3. Leontyev V. G. Motivacija i psikhologicheskije mekhanismy jejo formiroivanija [Motivation and psychological mechanisms of its formation]. Novosibirsk, 2002. 264 p. [In Russ.].

4. Peterson L. G., Agapov Yu. V. Motivacija i samoopredelenije v uchebnoj dejatel'nosti [Motivation and self-determination in the educational activity]. M., 2013. 64 p. [In Russ.].

5. Chernetskaya N. I. Tvorcheskoje myshlenije i tvorchestvo: $\mathrm{k}$ probleme sootnoshenija ponyatij [Creative thinking and creativity: to the problem of concepts ratio // Vestnik of Tver' stejt junivesiti. Serija "Pedagogika i psikhologija" [Bulletin of Tver State University. Series 
"Pedagogy and Psychology"].2013.Issue 1. Pp. 6-10. URL: https://elibrary.ru/item.asp?id=21272765 (20.03.2019) [In Russ.].

6. Chernetskaya N. I. Tvorcheskoje myshlenije kak edinstvo processualnykh i lichnostnykh psikhologicheskikh sostavljauschikh [Creative thinking as a unity of procedural and personal mental components] //Sibirskij pedagogicheskij zhurnal [Siberian pedagogical journal]. 2010. No. 11. Pp. 203-211. URL: https://elibrary.ru/item.asp?id=18041222 (20.03.2019) [In Russ.].

7. Shapovalenko I. V. Vozrastnaja psikhologija (psikhologija razvitija i vozrastnaja psikhologija [Age psychology (developmental psychology and age psychology]. M., 2004. 349 p. [In Russ.]. 


\section{РЕЦЕНЗИЯ}

DOI 10.31443/2541-8874-2019-2-10-169-172

УДК 94(438+571.1/.5)+94(=162.1)

Семенов Е.В.

Semeynov Ye. V.

РЕЦЕНЗИЯ НА КНИГУ: NIEBELSKI E. JÓZEF PILSUDSKI NA

SYBERII 1887-1892. - LUBLIN : POLIHYMNIA, 2018. -319 C. $=$ НЕБЭЛЬСКИЙ Е. ЮЗЕФ ПИЛСУДСКИЙ В СИБИРИ. 1887-1892 ГГ. - ЛЮБЛИН : POLIHYMNIA, 2018. - 319 С.

THE BOOK REVIEW: NIEBELSKI E. JÓZEF PILSUDSKI NA SYBERII 1887-1892. - LUBLIN : POLIHYMNIA, 2018. -319 p.= NEBELSKI Ye. JOSEPH PILSUDSKY IN SIBERIA. 1887-1892. LUBLIN : POLIHYMNIA, 2018. - 319 p.

2018 г. в истории Польши был отмечен важным юбилеем - 100-летием независимости государства. Ключевую роль в завоевании независимости сыграл Юзеф Пилсудский, находившийся в ссылке в 1887-1892 гг. в Сибири. Именно этому периоду жизни видного государственного деятеля Польши начала XX в. посвящена рецензируемая работа. В числе многочисленных публикаций, посвященных Ю. Пилсудскому, в том числе переведенных на русский язык [1], эта работа занимает особое место, поскольку охватывает один из ключевых моментов его жизни, сыгравших важную роль в становлении Ю. Пилсудского как политика и государственного деятеля.

Автором-составителем работы «Юзеф Пилсудский в Сибири. 1887-1892 гг.» является доктор исторических наук, профессор Люблинского католического университета (Люблин, Польша) Евгений Небэльский. Исследователь вот уже на протяжении многих лет занимается изучением вопросов пребывания ссыльных поляков в Байкальском регионе.

В последнее десятилетие Е. Небэльским опубликован ряд работ, отражающих основные моменты ссылки поляков в Сибирь, в их числе «Тунка. Сибирские судьбы ссыльных священников 1863 года» [5], «Лучше пуля, чем такая жизнь!» Польское восстание на Байкале 1866 года» [4], «Матращ С. Дорога в Сибирь по московским этапам в 1863 и 1864 гг.» [2].

Его новая работа посвящена одному из малоизученных аспектов биографии Ю. Пилсудского. Хотя этот период жизни основателя современного польского государства был рассмотрен еще в 30-е гг. XX в. личным адъютантом Ю. Пилсудского М. Лепецким, совершившим поездку по местам ссылки основателя польского государства, но, тем не менее, эта тема не была полно представлена в современной польской и россий- 
ской историографии. Настоящая работа, опирающаяся на широкий круг источников, в том числе впервые вводимых в научный оборот, значительно дополняет и расширяет представленную тему.

Сам автор отмечает, что данная работа является совместным трудом пяти авторов: собственно автора работы Евгений Небэльского; одного из ведущих специалистов в области изучения истории польской политической ссылки в Сибири и вклада польских исследователей в изучение этого региона Збигнева Вуйчика; современников Ю. Пилсудского - Владимира Бурцева и Юзефа Кобылянского и, конечно же, самого героя книги - Юзефа Пилсудского.

Первая глава «Братья Пилсудские в сибирской ссылке» подготовлена 3. Вуйчиком и рассказывает о пребывании Бронислава и Юзефа Пилсудских в ссылке в Восточной Сибири и на острове Сахалин. Оба брата, обвиненные в участии на покушение на жизнь императора, были направлены в разные места для отбывания наказания: Юзеф - в Киренск, а впоследствии в Тунку, Бронислав - в Корсаковский пост (совр. Корсаков) на Сахалине. Автор раздела описывает дорогу обоих братьев к месту отбывания наказания и условия отбывания наказания. Время пребывания Ю. Пилсудского в Киренске и Тунке было отмечено встречами с другими ссыльными, значительно повлиявшими на его мировоззрение и формирование социалистических взглядов. Особое влияние на молодого Ю. Пилсудского имел Б. Шварце. Позднее сам Ю. Пилсудский вспоминал: «Брат отправился на каторгу, меня приговорили к пяти годам ссылки в Восточной Сибири. И только здесь, я смог спокойно подумать надо всем, что пережил, я стал тем, кем являюсь» [3, с. 26].

Значительный фрагмент раздела посвящен научно-исследовательской деятельности Б. Пилсудского на Сахалине и в Японии по изучению культуры аборигенного населения Сахалина - айнов.

Второй раздел «Юзеф Пилсудский в кругу ссыльных» включает в себя ряд очерков как Е. Небэльского, так и воспоминания Юзефа Пилсудского и его современников о пребывании главного героя книги в Сибири.

В первом очерке Е. Небэльский описывает дорогу Ю. Пилсудского в ссылку, опираясь не только на воспоминания Ю. Пилсудского, но также включает анализ статейного списка на «государственного преступника Иосифа Пилсудского». Второй очерк посвящен пребыванию Ю. Пилсудского в Тунке в 1890-1892 гг. и характеристике взаимоотношений, сложившихся у польского ссыльного с другими польскими и российскими «государственными преступниками», находившимися на поселении в Тунке.

Во время пребывания Ю. Пилсудского в Тунке там находилось 19 ссыльных, из которых Ю. Пилсудский был самым молодым. Наиболее близкие отношения у него сложились с членами польской партии «Пролетариат» С. Юшчинским и М. Манцевичем, Б. Шварце, а также российскими революционерами В. Рклицким и Л. Лойко. Практически всем чле- 
нам тункинской общины ссыльных Ю. Пилсудский давал меткие характеристики.

В раздел включены воспоминания Ю. Пилсудского о бунте польских ссыльных в Иркутске, в котором он принял активное участие, пострадал и за что понес дополнительное наказание.

Юзеф Кобылянский записал со слов Ю. Пилсудского несколько рассказов об охоте в Тункинской долине. По воспоминаниям современников и ссыльных, находившихся в одно время с Пилсудским в Тунке, охота была одним из его наиболее любимых занятий.

Завершают раздел воспоминания Владимира Бурцева «Мои встречи с Пилсудским (в тюрьме, в Сибири и за границей)». В. Бурцев следовал в одной группе политических ссыльных с молодым Ю. Пилсудским и достаточно близко познакомился с ним. В то же время он отмечает какоето особое качество польских ссыльных, в особенности Ю. Пилсудского, выделявшее его из среды и польских ссыльных. По словам В. Бурцева: «Пилсудского и Гомолецкого объединяли в тюрьме особые чувства. Оба были польскими националистами - неуступчивыми, «железобетон» как потом таких называли в революционных кругах - фанатики» [3, с. 155]. Впоследствии В. Бурцев и Ю. Пилсудский также встречались, в том числе после завоевания Польшей независимости, и, несмотря на различие в политических взглядах сохраняли добрые отношения.

Содержание этого раздела, по моему личному мнению, призвано показать Ю. Пилсудского как обычного человека, ссыльного, оказавшегося в тяжелых условиях, вдали от родных и друзей, старавшегося всеми силами найти себя в новой реальности, в которой он оказался по воле судьбы.

Третья глава «Сибирские письма Юзефа Пилсудского 1887-1892 гг.» содержат письма, отправленные Ю. Пилсудским из Киренска и Тунки своим родным и друзьям, а также впервые публикуемые письма Ю. Пилсудского, которые адресованы его возлюбленной Леонарде Левандовской, с которой он познакомился во время ссылки в Киренске.

Автор справедливо замечает: «Стоит сожалеть, что в сумме этих писем сохранилось немного. А Пилсудский писал интересно и эти уцелевшие (письма) подтверждают, что мы могли бы узнать в многочисленных подробностях интересную сегодня для нас сибирскую жизнь Пилсудского. Вообще он писал так, как тогда писали: обо всем, что с ним случилось, о круге знакомых и друзей, о своем здоровье, о психическом состоянии. Был в этом искренний и аутентичный» [3, с. 183].

Подавляющее большинство писем адресовано Леонарде Левандовской. В письмах Ю. Пилсудский описывает свои ежедневные занятия, и все они пронизаны исключительным чувством нежности.

Издание богато иллюстрировано большим количеством фотопортретов современников Ю. Пилсудского в рассматриваемый период, гравюрами авторства М. Лепецкого, а также включает в себя значительное количество фотографий Иркутска, Енисейска и Тунки XIX - начала XX вв. 
Издание, подготовленное Е. Небельским, несомненно, является важной публикацией, раскрывающей наименее исследованные моменты жизни Ю. Пилсудского, и может быть интересно как польским, так и российским исследователям.

\section{Примечания}

1. Наленч Д., Наленч Т. Юзеф Пилсудский. Легенды и факты. М. : Политиздат, 1990. 399 с.

2. Matraś S. Podróż do Syberii po moskiewskich etapach w 1863 i 1864 roku. Lublin : Wydawnictwo Werset, 2008. $412 \mathrm{~s}$.

3. Niebelski E. Józef Piłsudski na Syberii. 1887-1892. Lublin : POLIHYMNIA, 2018. $319 \mathrm{c}$.

4. Niebelski E. «Lepsza nam kula niźli takie życie!». Polskie powstanie nad Bajkałem w 1866 roku. Lublin : Polska Akademia Nauk Oddział w Lublinie, 2016. $165 \mathrm{~s}$.

5. Niebelski E. Tunka. Syberyjskie losy księży zesłańców 1863 roku. Wrocław : Polskie Towarzystwo Ludoznawcze, 2011. 394 s.

\section{References}

1. Nalench D., Nalench T. Juzef Pilsudky. Legendy i fakty [Joseph Pilsudski. Legends and facts]. M., 1990. 399 s. [In Pol.].

2. Matraś S. Podróż do Syberii po moskiewskich etapach w 1863 i 1864 roku. Lublin, 2008. 412 s. [In Pol.].

3. Niebelski E. Józef Piłsudski na Syberii 1887-1892. Lublin, 2018. 319 [In Pol.].

4. Niebelski E. «Lepsza nam kula niźli takie życie!». Polskie powstanie nad Bajkałem w 1866 roku. Lublin : Polska Akademia Nauk Oddział w Lublinie, 2016. 165 s. [In Pol.].

5.Niebelski E. Tunka. Syberyjskie losy księży zesłańców 1863 roku. Wrocław : Polskie Towarzystwo Ludoznawcze, 2011. 394 s. [In Pol.]. 


\section{СВЕДЕНИЯ ОБ АВТОРАХ}

1. Бальжитова Ольга Михайловна, кандидат философских наук, младший научный сотрудник естественно-научного центра ГАУК РБ «Национальный музей Республики Бурятия» (г. Улан-Удэ)

2. Батоцыренов Эдуард Аюрович, кандидат географических наук, научный сотрудник ФГБУН Байкальский институт природопользования СО РАН (г. Улан-Удэ).

3. Васильева Наталья Юрьевна, научный сотрудник ГАУК РБ «Кяхтинский краеведческий музей им. академика В.А. Обручева» (г. Кяхта)

4. Васильев Владимир Митапович, хранитель фондов музея БНЦ СО РАН (г. Улан-Удэ).

5. Гульбина Анна Алексеевна, заместитель директора по развитию дальневосточного морского заповедника-филиала Национального научного центра морской биологии (г. Владивосток).

6. Дандарон Мэдэгма Бидияевна, доктор философских наук, профессор кафедры истории и философии ФГБОУ ВО ВСГИК (г. Улан-Удэ).

7. Долгополова Любовь Владимировна, специалист по учебно-методической работе 1 категории дирекции Института истории и международных отношений, магистрант 1 года обучения направления подготовки «Туризм» ФГБОУ ВО «Кемеровский государственный университет» (г. Кемерово).

8. Донгак Валерия Чаш-ооловна, старший научный сотрудник отдела краеведения и туризма ГБУ РТ «Национальный музей им. АлданМаадыр Республики Тыва» (г. Кызыл)

9. Епина Марина Борисовна, заведующая сектором истории Музея ФГАОУ ВО «Сибирский федеральный университет» (г. Красноярск)

10. Жущиховская Ирина Сергеевна, доктор исторических наук, ведущий научный сотрудник Музея археологии и этнографии Дальнего Востока Института истории, археологии и этнографии народов Дальнего Востока ДВО РАН (г. Владивосток).

11. Замоева Елена Константиновна, старший преподаватель кафедры истории и философии ФГБОУ ВО ВСГИК (г. Улан-Удэ).

12. Кравцова Людмила Александровна, кандидат культурологии, ведущий научный сотрудник Кабинета истории угольной промышленности Кузбасса Федерального исследовательского центра угля и углехимии СО РАН (г.Кемерово).

13. Матющенко Ольга Ивановна, старший преподаватель кафедры музеологии, культурного наследия Института искусств и культуры ФГАОУ ВО «Национальный исследовательский Томский государственный университет» (г. Томск).

14. Монгуш Шолбана Хонук-ооловна, старший научный сотрудник отдела археологии и этнографии ГБУ РТ «Национальный музей им. Алдан-Маадыр Республики Тыва» (г. Кызыл). 
15. Николаева Наталия Викторовна, старший преподаватель кафедры режиссуры эстрады и театрализованных представлений ФГБОУ ВО ВСГИК (г. Улан-Удэ).

16. Новолодская Мария Сергеевна, кандидат исторических наук, главный специалист отдела публикации документов ГАУК РБ «Государственный архив Республики Бурятия» (г. Улан-Удэ).

17. Покацкая Елена Ивановна, преподаватель кафедры педагогики и психологии ФГБОУ ВО ВСГИК (г. Улан-Удэ).

18. Румянцева Анна Сергеевна, директор Музея ФГАОУ ВО «Сибирский федеральный университет» (г. Красноярск).

19. Санданов Денис Викторович, кандидат биологических наук, старший научный сотрудник ФГБУН Институт общей и экспериментальной биологии СО РАН (г. Улан-Удэ).

20. Свистов Никита Леонидович, младший научный сотрудник лаборатории антропологии северной пасифики Института истории, археологии и этнографии ДВО РАН (г. Владивосток).

21. Семенов Евгений Владимирович, кандидат исторических наук, доцент кафедры музеологии и наследия ФГБОУ ВО ВСГИК (г. Улан-Удэ).

22. Суптелова Анна Владимировна, магистрант 1 года обучения, направление подготовки «Туризм» Института истории и международных отношений ФГБОУ ВО «Кемеровский государственный университет» (г. Кемерово).

23. Терскова Аида Александровна, кандидат исторических наук, старший научный сотрудник Музея ФГАОУ ВО «Сибирский федеральный университет» (г. Красноярск).

24. Цибудеева Надежда Цыденовна, кандидат искусствоведения, доцент ФГБОУ ВО ВСГИК (г. Улан-Удэ).

25. Цыремпилов Даши Владимирович, главный архивист отдела публикации документов ГАУК РБ «Государственный архив Республики Бурятия» (г. Улан-Удэ).

26. Цыренжапова Лидия Михайловна, кандидат экономических наук, доцент кафедры социально-культурной деятельности ФГБОУ ВО ВСГИК (г. Улан-Удэ).

27. Хамаева Елена Доржиевна, ведущий архивист отдела публикации документов ГАУК РБ «Государственный архив Республики Бурятия» (г. Улан-Удэ)

28. Ян Ли, профессор факультета русского языка Чанчуньского политехнического университета (г. Чанчунь, КНР) 


\section{INFORMATION ABOUT THE AUTHORS}

1. Balzhitova Olga Mikhailovna, Ph.D. in Philosophy, junior researcher of the natural scientific center, SAEC RB «National museum of the Republic of Buryatia» (Ulan-Ude city).

2. Batotsyrenov Eduard Ayurovich, Ph.D. in Geography, researcher, FSBIS Baikal institute of nature use SB RAS (Ulan-Ude city).

3. Vasilyeva Natalya Yuriyevna, researcher, SAEC RB «Kyakhta local history museum named after V. A. Obruchev» (Kyakhta town).

4. Vasilyev Vladimir Mitapovich, custodian of the museum funds, BSC SB RAS (Ulan-Ude city).

5. Gulbina Anna Alexeevna, deputy director in charge of developing Far eastern marine reserve-branch, the National scientific center of marine biology (Vladivostok city).

6. Dandaron Medegma Bidiyaevna, D. Sc. In Philosophy, professor of the department of history and philosophy, FSBEI HE ESSIC (Ulan-Ude city).

7. Dolgopolova Lyubov Vladimirovna, 1st category specialist in charge of teaching and guiding work of the directorate, Institute of history and international relations, $1^{\text {st }}$-year magistrate, specialty «Tourism», FSBEI HE Kemerovo state university (Kemerovo city).

8. Dongak Valeriya Chash-oolovna, senior researcher of the local history and tourism department, SBE RT «National museum of the Republic of Tuva named after Aldyn-Maadyr (Kyzyl city).

9. Epina Marina Borisovna, chief of the history sector, Museum of FSAEI HE Siberian federal university (Krasnoyarsk city).

10. Zhushchikhovskaya Irina Sergeevna, Sc. D. in History, leading researcher of the Museum of archaelogy and ethnography of the Far east, Institute of history, archaelogy and ethnography of the Far east peoples, FEB RAS (Vladivostok city).

11. Zamoeva Ye.K., senior teacher of the department of history and philosophy, FSBEI HE ESSIC (Ulan-Ude city).

12. Kravtsova Lyudmila Alexandrovna, Ph.D. in Culturology, leading scientific employee of the history Cabinet of coal industry of Kuzbass, Federal research center of coal and carbon chemistry of SB RAS (Kemerovo city).

13. Matyushchenko Olga Ivanovna, senior teacher of the department of museology, cultural heritage of the Institute of arts and culture, FSAEI National research Tomsk state university (Tomsk city).

14. Mongush Sholbana Khonuk-oolovna, senior researcher of the department of archaelogy and ethnography, SBE RT «National museum of the Republic of Tuva named after Aldyn-Maadyr (Kyzyl city).

15. Nikolaeva Nataliya Viktorovna, senior teacher of the department of directing variety and theatrical performances, FSBEI HE ESSIC (Ulan-Ude city). 
16. Novolodskaya Mariya Sergeevna, Ph.D. in History, chief specialist of the department of documents publication, SAEC RB «State archive of the Republic of Buryatia» (Ulan-Ude city).

17. Pokatskaya Yelena Ivanovna, teacher of the department of pedagogy and psychology, FSBEI HE ESSIC (Ulan-Ude city).

18. Rumyantseva Anna Sergeevna, director of the Museum, FSAEI HE Siberian federal university (Krasnoyarsk city).

19. Sandanov Denis Viktorovich, Ph.D. in Biology, senior researcher of FSBIS Institute of general and experimental biology SB RAS (Ulan-Ude city).

20. Svistov Nikita Leonidovich, junior researcher of the laboratory of the northern pacifics antropology, Institute of history, archaelogy and ethnography, FEB RAS (Vladivostok city).

21. Semyonov Evgeniy Vladimirovich, Ph.D. in History, associate professor of the department of museology and heritage, FSBEI HE ESSIC (Ulan-Ude city).

22. Suptelova Anna Vladimirovna, $1^{\text {st }}$-year magistrate, specialty «Tourism», Institute of history and international relations, FSBEI HE Kemerovo state university (Kemerovo city).

23. Terskova Aida Alexandrovna, Ph.D. in History, senior researcher of the Museum, FSAEI HE Siberian federal university (Krasnoyarsk city).

24. Tsybudeeva Nadezhda Tsydenovna, PhD in Arts History, associate professor, FSBEI HE ESSIC (Ulan-Ude city).

25. Tsyrempilov Dashi Vladimirovich, chief archivist of the documents publication deparment, SAEC RB «State archive of the Republic of Buryatia» (Ulan-Ude city).

26. Tsyrenzhapova Lidiya Mikhailovna, Ph.D. in Economy, associate professor of the department of social-cultural activity, FSBEI HE ESSIC (Ulan-Ude city).

27. Khamaeva Yelena Dorzhievna, leading archivist of the documents publication deparment, SAEC RB «State archive of the Republic of Buryatia» (Ulan-Ude city).

28. Jan Li, professor of the Russian language department, Changchun polytechnical university (Changchun, China). 


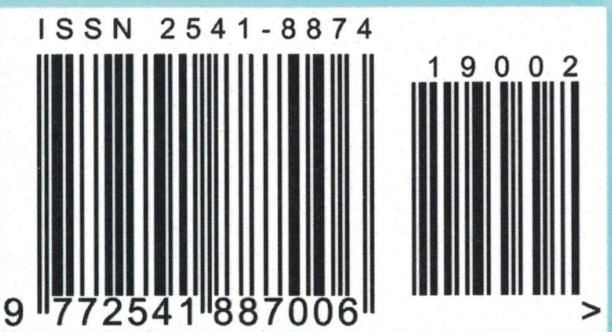

